\title{
Relating recharge mechanisms to chemical changes in an updip Appalachian coal mine discharge: A case study from Lambert Run, West Virginia
}

Matthew Lewis Bell

West Virginia University, mlb0083@mix.wvu.edu

Follow this and additional works at: https://researchrepository.wvu.edu/etd

Part of the Environmental Monitoring Commons, Geochemistry Commons, and the Hydrology Commons

\section{Recommended Citation}

Bell, Matthew Lewis, "Relating recharge mechanisms to chemical changes in an updip Appalachian coal mine discharge: A case study from Lambert Run, West Virginia" (2020). Graduate Theses, Dissertations, and Problem Reports. 7772.

https://researchrepository.wvu.edu/etd/7772

This Thesis is protected by copyright and/or related rights. It has been brought to you by the The Research Repository @ WVU with permission from the rights-holder(s). You are free to use this Thesis in any way that is permitted by the copyright and related rights legislation that applies to your use. For other uses you must obtain permission from the rights-holder(s) directly, unless additional rights are indicated by a Creative Commons license in the record and/ or on the work itself. This Thesis has been accepted for inclusion in WVU Graduate Theses, Dissertations, and Problem Reports collection by an authorized administrator of The Research Repository @ WVU. For more information, please contact researchrepository@mail.wvu.edu. 
Relating recharge mechanisms to chemical changes in an updip Appalachian coal mine discharge: A case study from Lambert Run, West Virginia

Matthew Lewis Bell

\author{
Thesis submitted \\ to the Eberly College of Arts and Sciences \\ at West Virginia University \\ in partial fulfillment of the requirements for the degree of \\ Master of Science in \\ Geology
}

\author{
Dorothy J. Vesper, Ph.D., Chair \\ Christopher J. Russoniello, Ph.D. \\ Louis M. McDonald, Ph.D. \\ Department of Geology and Geography \\ Morgantown, West Virginia
}

2020

Keywords: Rare earth elements, $\mathrm{CO}_{2}$, coal mine drainage, aqueous geochemistry, inorganic carbon, water quality

Copyright 2020 Matthew Bell 


\title{
Abstract \\ Relating recharge mechanisms to chemical changes in an updip Appalachian coal mine discharge: A case study from Lambert Run, West Virginia
}

\author{
Matthew Lewis Bell
}

Impaired drainage from active and abandoned mines degrades the water quality of receiving streams and aquifers. Coal mine drainage (CMD) has been studied for decades in Appalachia, but unknowns and uncertainties are still present, including the influence of mine hydrogeology on the outflow chemistry of above-drainage mines. To evaluate the influence of recharge type on above-drainage mine chemistry, samples were collected every two weeks at a CMD outflow treatment system in Harrison County, West Virginia. Samples were collected to measure geochemical changes taking place in the mine workings and along the flowpath of the passive treatment system.

Samples were divided into two groups based on the dominant type of recharge entering the mine during sample collection. Direct recharge dominated samples had lower concentrations of hydrolysable cations at the mine outflow, causing the discharge to be both net-acidic and netalkaline during the study period. Total rare earth element concentrations at the outflow were positively correlated to $\mathrm{Fe}, \mathrm{Al}$, and $\mathrm{Mn}$, and negatively correlated to $\mathrm{pH}$ and discharge. During both recharge regimes, $\mathrm{Fe}, \mathrm{Al}, \mathrm{Mn}$, and rare earth elements were removed along the treatment system flowpath. Throughout the study period, $89 \%$ of dissolved inorganic carbon in the system was degassed to the atmosphere as $\mathrm{CO}_{2}$.

This study demonstrates that varied recharge mechanisms can influence the CMD outflow chemistry, with implications in treatment system design, interpretation of routine chemical data, and extrapolation of $\mathrm{CO}_{2}$ efflux from CMD outflows for large-scale carbon balance studies. 


\section{Acknowledgements}

First and foremost, I would like to thank my family: Michele, Ken, and Justin. Without their love and support throughout my career and education, I would not be half the man I am today. Thank you to advisors and mentors who always pushed me to ask more questions and never be satisfied by the answers of the day. Especially Dorothy Vesper, who fostered an unmatched atmosphere of learning and growth. Thanks to Chris Russoniello and Louis McDonald for keen advice and suggestion throughout the thesis process. Extra special thanks to Jill Riddell and Autum Downey for laboratory and field assistance, relaxation, and productivity boosts at our satellite office locations. Additional thanks to Joe Donovan and Steve Kite for their donations of conversation, resources, and more accumulated knowledge than I could ever hope to digest. The favors of all throughout my time at West Virginia University, however small, are held in equal remembrance. 


\section{Table of Contents}

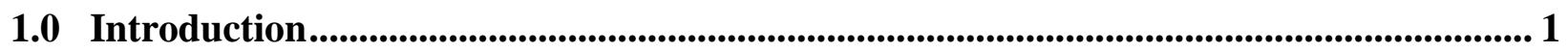

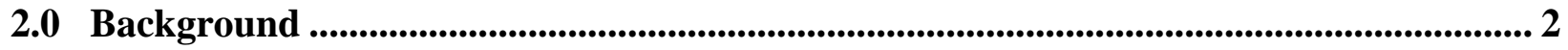

2.1 Coal Mine Hydrogeology ................................................................................... 2

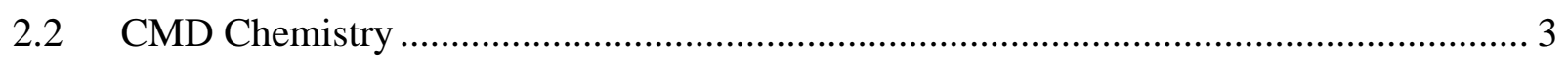

2.3 Rare Earth Element Chemistry ............................................................................ 3

$2.4 \quad \mathrm{CaCO}_{3}-\mathrm{Water}$ System Chemistry ….............................................................. 7

2.5 Processes Related to Recharge Influencing Mine Drainage Chemistry......................... 8

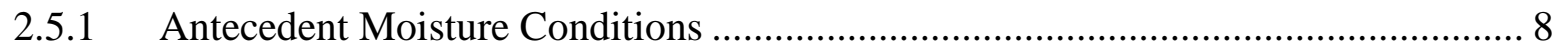

2.5.2 Mobilization of Stored Water ........................................................................ 8

2.6 Statement of Problem ........................................................................................ 8

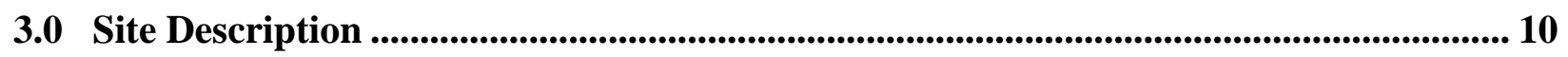

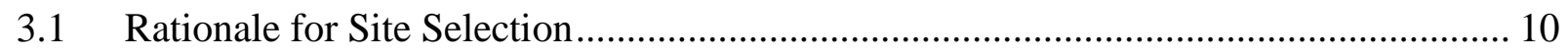

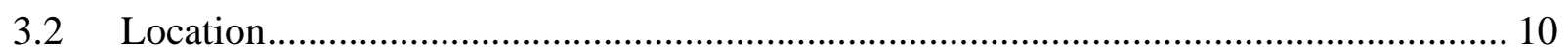

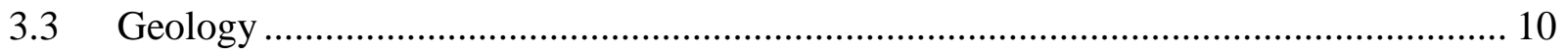

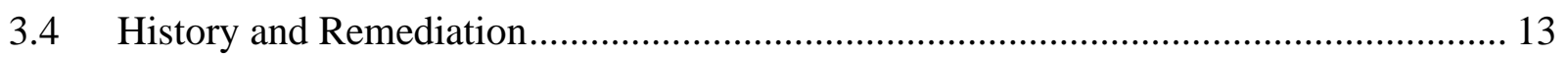

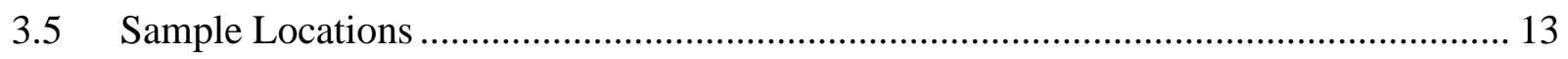

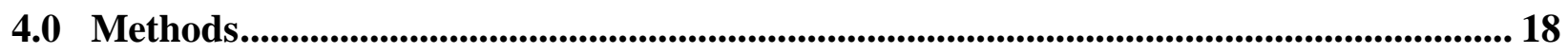

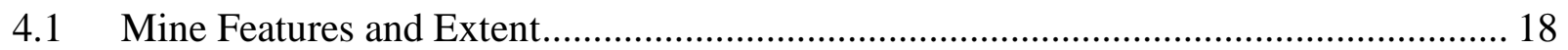

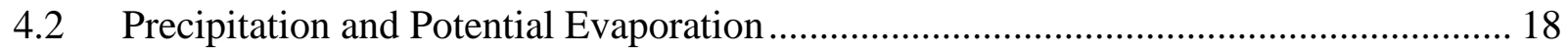

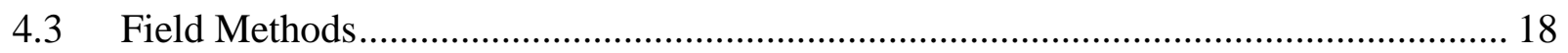

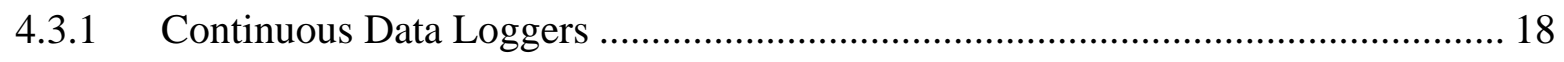

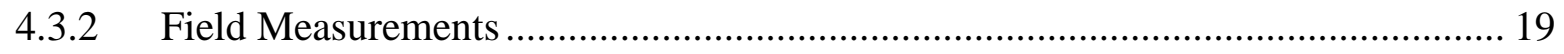

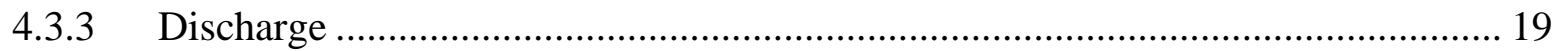

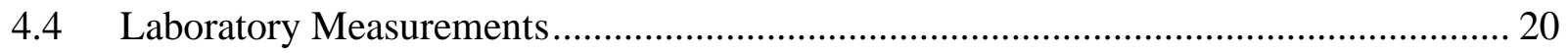

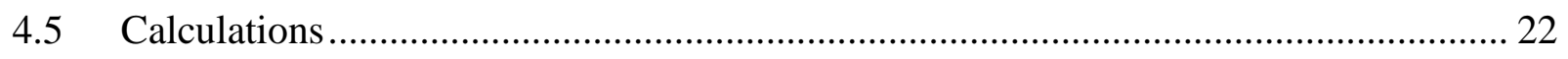

4.5.1 Geochemical Modeling .............................................................................. 22

4.5.2 Potential Acidity ........................................................................................... 22

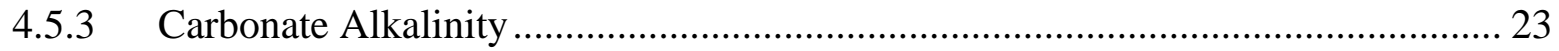

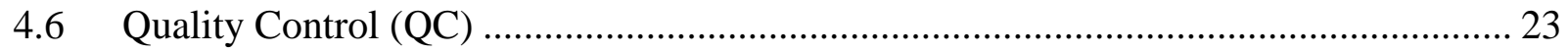

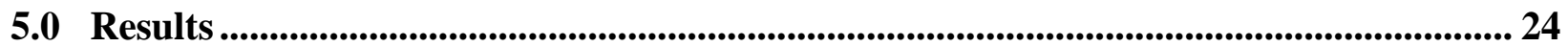


5.1 Mine Hydrogeology ......................................................................................... 24

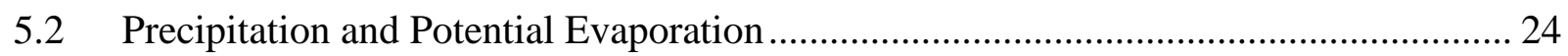

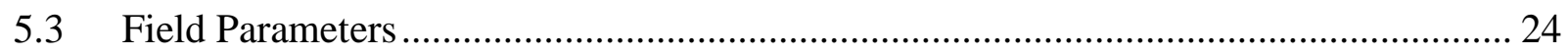

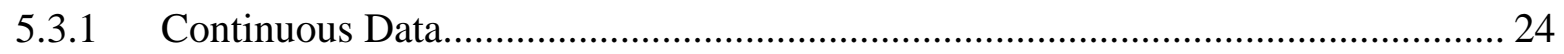

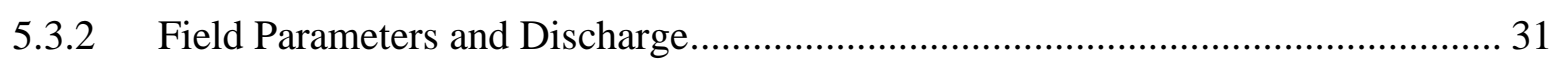

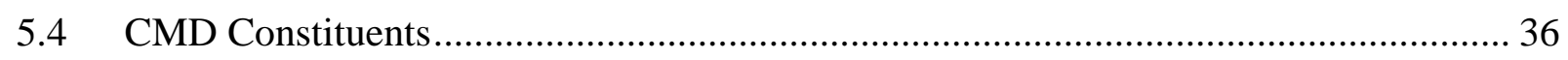

5.5 Yttrium and Rare Earth Elements (YREE) ……….................................................... 43

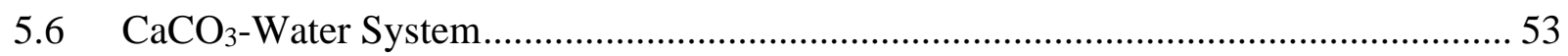

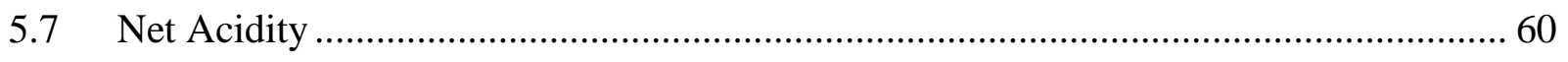

6.0 Discussion and Interpretation......................................................................................65

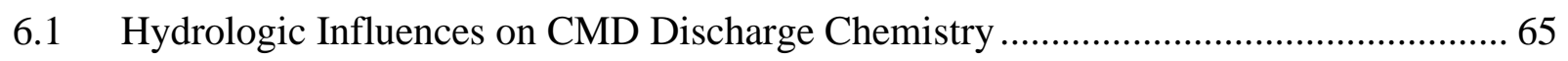

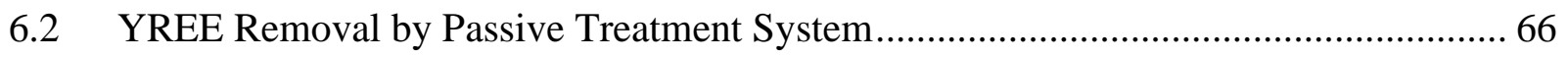

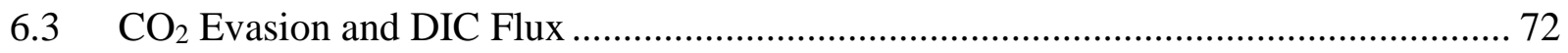

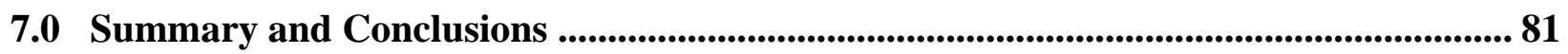

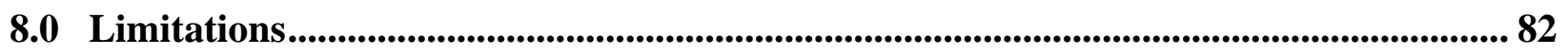

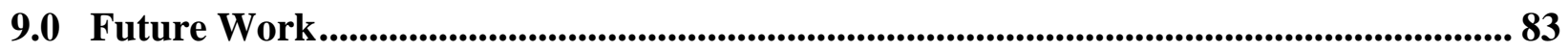



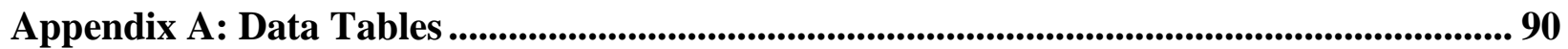

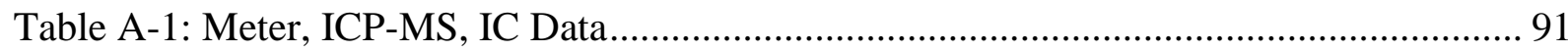

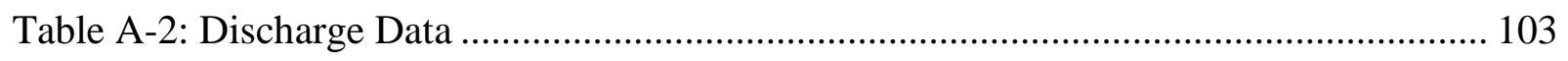

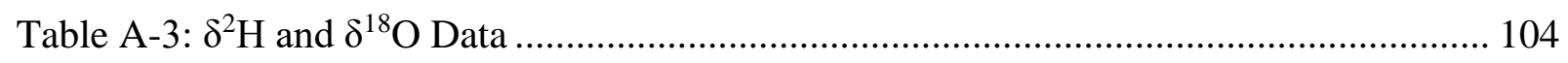

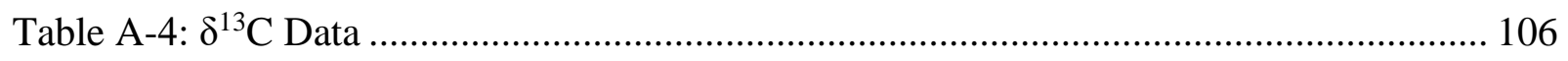

Appendix B: Complete Correlation Matrices ........................................................................................ 107

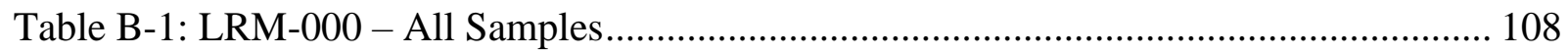

Table B-2: LRM-000 - Diffuse Recharge Dominated Samples …………………………….... 109

Table B-3: LRM-000 - Direct Recharge Dominated Samples................................................. 110

Appendix C: YREE Thermodynamic Data Corrections................................................................ 111

Appendix D: Duplicate Sample Results ............................................................................................... 112

Appendix E: Blank Sample Results..................................................................................................... 113

Table E-1: Maximum Detected Concentrations in Blank Samples ......................................... 114

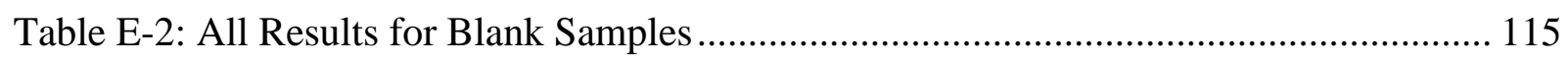




\section{List of Figures}

Figure 1: (A) generalized above-drainage/updip mine hydrogeology, where water flows downdip along the mine floor. Updip mines are generally unsaturated. (B) generalized belowdrainage/downdip mine hydrogeology, where the mine workings flood if pumping is not maintained.

Figure 2: Schematic diagram showing fracture density in mine overburden and post-closure changes to room and pillar mine workings, including sinking coal pillars, roof collapses, and the accumulation of rubble in the mine voids. These factors increase the complexity of updip mine hydrogeology.

Figure 3: Continuum between diffuse and direct recharge dominated CMD outflow signatures. . 6 Figure 4: DIC speciation at $20^{\circ} \mathrm{C}$ and total DIC concentration of $5 \mathrm{mmol} / \mathrm{L}$. The shaded portion of the plot shows the approximate $\mathrm{pH}$ range of the study location............................ 9

Figure 5: Regional hydrology and geography of the study area.......................................... 11

Figure 6: Geology of Harrison County, West Virginia...................................................... 12

Figure 7: Coal mine drainage outflow locations draining the Dawson No. 3 mine shown on (A) recent leaf-off aerial imagery, and (B)1936 Dawson No. 3 mine map.

Figure 8: LRM mine portal (A) during remediation and (B) post-remediation. Note two plastic outflow pipes circled in photo B. Photo A courtesy of John Eleyette, photo B courtesy of Mike Smilley.

Figure 9: LRM sample locations and site features. 17

Figure 10: Coal bed elevation contours and inferred capture zones based on downdip flow, shown on (A) recent leaf-off aerial imagery and (B) 1936 Dawson No. 3 mine map. 25

Figure 11: Monthly net precipitation at LRM for each water year since 2015, calculated using Thornthwaite's equation (1948). Note the prolonged period of deficit precipitation in 2019

Figure 12: Temperature data from data loggers at LRM-010 and LRM-SHS......................... 27

Figure 13: Continuous SC data at LRM-010 and LRM-SHS. ............................................ 30

Figure 14: Ranges of measured (A) water temperature, (B) $\mathrm{pH},(\mathrm{C})$ specific conductance, and (D) dissolved oxygen saturation at each sampling location. Whiskers represent maximum and minimum values.

Figure 15: Variability of (A) water temperature, $(\mathrm{B}) \mathrm{pH},(\mathrm{C})$ specific conductance, and (D) dissolved oxygen saturation at each sampling location relative to the dominant recharge type.

Figure 16: Temporal variability of field parameters at LRM-000 and their relation to discharge. Dashed line indicates division between diffuse recharge dominated (left) and direct recharge dominated (right) periods.

Figure 17: Concentration ranges of (A) Fe, (B), Al, (C), Mn, and (D) SO4 at each sampling location. Whiskers represent maximum and minimum values.

Figure 18: Variability of (A) Fe, (B) Al, (C) Mn, and (D) SO4 at each sampling location relative to the dominant recharge type. 38 
Figure 19: CMD constituent temporal variability at LRM-000. Dashed line indicates division between diffuse recharge dominated (left) and direct recharge dominated (right) periods.

Figure 20: Hydroxide solubility for major CMD cations. Grey bar indicates $\mathrm{pH}$ range at LRM000 during the study period. Solubility lines generated using Visual MINTEQ version 3.1 (Gustaffson, 2018), allowing unlimited supplies of each mineral to dissolve at $13^{\circ} \mathrm{C} . \mathrm{Al}(\mathrm{OH})_{3}$ and $\mathrm{Fe}(\mathrm{OH})_{2}$ modeled as amorphous forms. $\mathrm{Fe}(\mathrm{OH})_{3}$ modeled as unaged form.

Figure 21: CMD constituent loading variability at LRM-000. Dashed line indicates division between diffuse recharge dominated (left) and direct recharge dominated (right) periods.

Figure 22: Concentration range of total YREE at each sampling location. Whiskers represent maximum and minimum values.

Figure 23: Typical YREE enrichment relative to NASC (Gromet et al., 1984) at LRM. Data from samples collected on 12/18/2019.

Figure 24: Typical YREE removal along the LRM flowpath. Data from samples collected on $12 / 18 / 2019$

Figure 25: YREE removal anomaly where Y concentration increases along the flowpath. Data from samples collected on 10/18/2019.

Figure 26: YREE removal anomaly, where $\mathrm{Y}$ is not present at detectable concentrations at any sample location. Data from samples collected on 11/2/2019.

Figure 27: Total YREE concentration temporal variability at LRM-000. Dashed line indicates division between diffuse recharge dominated (left) and direct recharge dominated (right) periods

Figure 28: Temporal variability of YREE loading at LRM-000. Dashed line indicates division between diffuse recharge dominated (left) and direct recharge dominated (right) periods.

Figure 29: Concentration ranges of (A) DIC, (B), Ca, and (C), Mg at each sampling location. Whiskers represent maximum and minimum values. ............................................. 54

Figure 30: Spatial variation in PCO2 and pH during the study period..................................... 56

Figure 31: Temporal variations in DIC, temperature and $\mathrm{pH}$ at LRM-000. Dashed line indicates division between diffuse recharge dominated (left) and direct recharge dominated

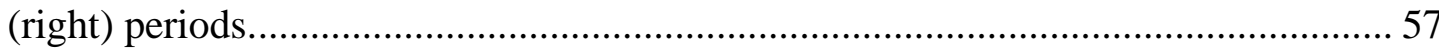

Figure 32: Correlation between temperature and DIC at LRM-000. Only includes samples collected directly from outflow pipe. Best fit line includes all samples................... 58

Figure 33: Net acidity range at each sample location. Whiskers represent maximum and

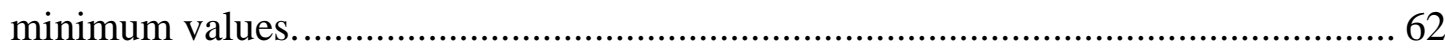

Figure 34: Net acidity variability relative to dominant recharge type .................................... 63

Figure 35: Temporal variation of net acidity at LRM-000 throughout the study period. Dashed line indicates division between diffuse recharge dominated (left) and direct recharge dominated (right) periods. 
Figure 36: Average concentrations at LRM-000 during diffuse and direct recharge dominated periods compared to bituminous coal mine outflow concentration ranges from Cravotta (2008). Whiskers represent minimum and maximum concentrations.

Figure 37: Concentrations expected from conservative dilution (dashed lines) of CMD constituents at LRM-000. Vertical dashed line indicates division between diffuse recharge dominated (left) and direct recharge dominated (right) periods. ..................6 68

Figure 38: Spatial variation in $\mathrm{PCO} 2$ vs $\mathrm{SI}_{\text {calcite }}$ during the study period. 69

Figure 39: Normalized concentration ranges at LRM compared to concentrations from Stewart et al. (2017) and Hedin et al. (2019). Concentration ranges from Stewart et al. are hatched with horizontal lines. Concentrations from Hedin et al. are hatched with vertical lines. LRM concentrations shown in grey. Samples with concentrations below detection are displayed as the normalized MDL concentration. MDL shown as black dashed line. 70

Figure 40: YREE concentration relative to $\mathrm{pH}$ at LRM compared to supplemental data from Stewart et al. (2017) and Hedin et al. (2019). Data from Stewart et al. (2017) are from 18 bituminous CMD outflows throughout Pennsylvania. Data from Hedin et al. (2019) are treated and untreated CMD samples from four different passive treatment systems.

Figure 41: YREE removal ratios normalized to LRM-000. Points are average values at each location, error bars are the standard deviation.

Figure 42: Spatial variation in (A) Ce anomaly, (B) La/Ce normalized ratio, and (C) Y/Ho unnormalized molar ratio. Where subscript $n$ indicates normalization to NASC (Gromet et al., 1984). Points are average values at each location, error bars are the standard deviation.

Figure 43: Temporal variability of CO2 efflux between LRM-000 to LRM-172 during the study period. Vertical dashed line indicates division between diffuse recharge dominated (left) and direct recharge dominated (right) periods.......................................... 76

Figure 44: Temporal variation of DIC sources and sinks throughout the study period.............. 77

Figure 45: DIC sources and sinks at LRM compared to Vesper et al. (2016)......................... 78

Figure 46: $\mathrm{CO}_{2}$ efflux directly to the atmosphere by unit area compared to other similar studies. Feature area refers to the size of the feature studied (i.e. mine size, watershed size). $\mathrm{MTR} / \mathrm{VF}=$ mountain top removal/valley fill mine practices. Range for LRM only accounts for $\mathrm{CO}_{2}$ flux from the LRM treatment flowpath. The area used for the LRM only range only includes the area of the limestone lined channel and the altered natural wetland, similar to the methods of Vesper et al. (2016). Range for Dawson No. 3 mine assumes flux at LRM is the same as flux at other CMD outflows draining the Dawson No. 3 mine ( 8 total outflows, total area $7.6 \mathrm{~km}^{2}$ ). MTR/VF flux from Ross et al. (2018), feature area for MTR/VF flux plotted as 50 acres, the maximum permitted size of valley fills in West Virginia (WVDEP, 2017). Diamond symbols are

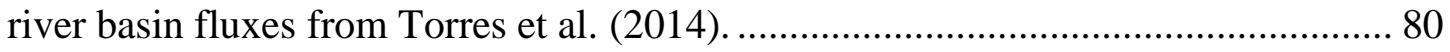

Figure 47: Percent difference results for duplicate sample pairs......................................... 112 


\section{List of Tables}

Table 1: Rare earth element groups, based on atomic weight and critical need for energy and

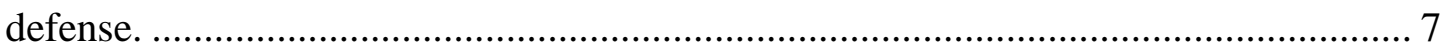

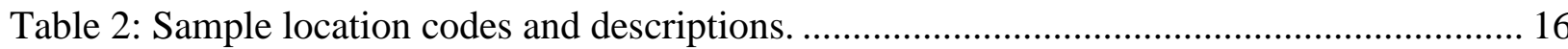

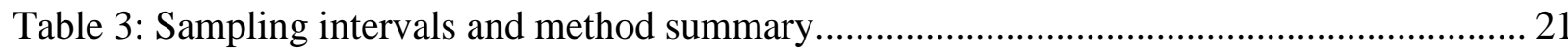

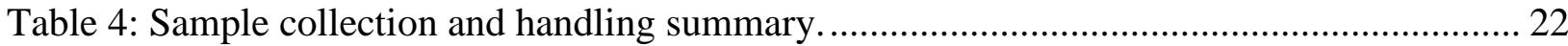

Table 5: Dominant recharge for each sampling date. ......................................................... 29

Table 6: LRM-000 field parameter correlations to discharge...................................................... 34

Table 7: Average CMD constituent removal between LRM-000 and LRM-172. When duplicate samples were collected at LRM-000, the non-duplicate sample was used for

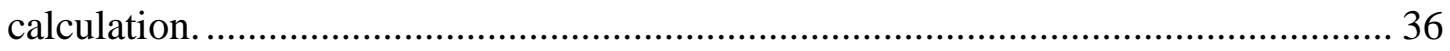

Table 8: Diffuse recharge dominated sample concentration ranges at LRM-000..................... 39

Table 9: Average CMD constituent concentrations at LRM-000 ......................................... 39

Table 10: LRM-000 CMD constituent correlations to discharge. Duplicate samples were

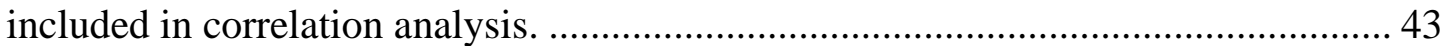

Table 11: Correlations to YREE at LRM-000..................................................................... 52

Table 12: Average $\mathrm{CaCO}_{3}$-water system concentration changes between LRM-SHS and LRM000 to illustrate geochemical processes within the mine.......................................... 53

Table 13: Average $\mathrm{CaCO}_{3}$-water system concentration changes between LRM-000 and LRM172 to indicate geochemical processes active in the treatment system. .................... 55

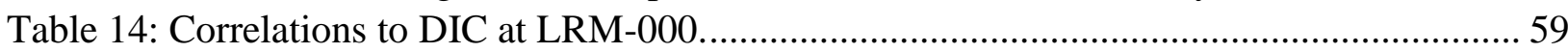

Table 15: Average mass of energy critical YREE removed per year at LRM. ........................ 66

Table 16: Log K values for REE-SO 4 complexes from Liu et al. (2017)............................. 111 


\section{List of Acronyms and Abbreviations}

$\begin{array}{ll}\text { BAC } & \text { Benzalkonium chloride } \\ \text { CBE } & \text { Charge Balance Error } \\ \text { CF-IRMS } & \text { Continuous-flow Isotope Ratio Mass Spectrometer } \\ \text { CMD } & \text { Coal Mine Drainage } \\ \text { DIC } & \text { Dissolved Inorganic Carbon } \\ \text { DO } & \text { Dissolved Oxygen } \\ \text { EPA } & \text { United States Environmental Protection Agency } \\ \text { HDPE } & \text { High-Density Polyethylene } \\ \text { HFO } & \text { Hydrous Ferric Oxide } \\ \text { HREE } & \text { Heavy Rare Earth Elements (Y, Nd, Dy, Eu, Tb) } \\ \text { IC } & \text { Ion Chromatography } \\ \text { ICP-MS } & \text { Inductively Coupled Plasma-Mass Spectrometry } \\ \text { LiDAR } & \text { Light Detection and Ranging } \\ \text { LLNL } & \text { Lawrence Livermore National Laboratory (PHREEQ Database) } \\ \text { LREE } & \text { Light Rare Earth Elements (La, Ce, Pr, Nd, Sm) } \\ \text { LRM } & \text { Lambert Run Muzzleloader Club mine drainage site, formerly called MZLC } \\ \text { MDL } & \text { Method Detection Limit } \\ \text { MREE } & \text { Middle Rare Earth Elements (Eu, Gd, Tb, Dy, Y) } \\ \text { MTR/VF } & \text { Mountain top removal/valley fill mining } \\ \text { MZLC } & \text { Muzzle Loader Club drainage site, per Smilley (2007). Same location as LRM } \\ \text { NRCCE } & \text { National Research Center for Coal Energy } \\ \text { ODO } & \text { Optical Dissolved Oxygen } \\ \text { QC } & \text { Quality Control } \\ \text { REE } & \text { Rare Earth Elements } \\ \text { SC } & \text { Specific Conductance } \\ \text { SD } & \text { Standard Deviation } \\ \text { USGS } & \text { United States Geological Survey } \\ \text { VSMOW } & \text { Vienna Standard Mean Ocean Water } \\ \text { VPDB } & \text { Vienna Pee Dee Belemnite } \\ \text { WVDEP } & \text { West Virginia Department of Environmental Protection } \\ \text { WVGES } & \text { West Virginia Geologic and Economic Survey } \\ \text { YREE } & \text { Yttrium and Rare Earth Elements } \\ & \end{array}$




\subsection{Introduction}

Throughout the coalfields of the world, impaired drainage from mines remains a problem, despite widespread efforts to mitigate and remediate. In West Virginia, an estimated 18,620 stream kilometers are impaired by coal mine drainage constituents, including $\mathrm{Fe}, \mathrm{Al}, \mathrm{Mn}, \mathrm{SO}_{4}$ and acidity (WVDEP, 2016). Coal mine drainage (CMD) has been well studied throughout space and time, including the evolution of drainage chemistry over multiple years (Donovan et al., 2003), seasons (Kim and Kim, 2004; Burrows et al., 2015), and hours (Nimick et al., 2003; Gammons et al., 2005; Vesper and Smilley, 2010). Such studies help scientists understand the mechanisms of mine drainage chemistry and its evolution through time. Understanding the processes controlling mine drainage chemistry has implications in the remediation of impaired waters and prediction of future trends in mine drainage outflows.

CMD outflows export dissolved metals, $\mathrm{SO}_{4}$, and dissolved inorganic carbon (DIC) to receiving waterways. The export of DIC can be rapid relative to global carbon cycles if $\mathrm{CO}_{2}$ is directly degassed to the atmosphere rather than transported to the ocean and eventually degassed. Widespread estimation of metals and DIC from CMD outflows is difficult to constrain due to the large number of outflows in mined regions (Cravotta, 2008). It is especially difficult to accurately determine DIC output, because directly measuring $\mathrm{CO}_{2}$ at low $\mathrm{pH}$ and alkalinity at high $\mathrm{pH}$ is difficult and likely imprecise (Cravotta et al., 1999). $\mathrm{CO}_{2}$ emitted from mine discharges is often unreliably calculated and underestimated globally due to measurement difficulty and the number of CMD sites (Vesper et al., 2016). Literature addressing $\mathrm{CO}_{2}$ emission from coal mine systems has comparatively few studies that directly measure $\mathrm{CO}_{2}$ concentrations at the point of discharge (Raymond and Oh, 2009; Fox and Campbell, 2010; Vesper et al., 2016; Ross et al., 2018). Even fewer studies address the potential for low $\mathrm{pH}$ outflows with excess $\mathrm{CO}_{2}$ to impact global carbon balances on a geologically rapid timeline. Although this study does not attempt to extrapolate carbon flux to a global scale, it does demonstrate a case that should be considered further in global carbon balances. Analyzing how precipitation and recharge trends influence the $\mathrm{CO}_{2}$ and metal flux from CMD outflows helps scientists understand the mechanisms governing the concentrations of these constituents in mine waters, and their eventual export to the atmosphere and receiving waterways. Varying recharge sources entering above-drainage mines provide a unique opportunity to study the geochemical processes and interactions taking place in the subsurface.

Studying the effect of varying recharge mechanisms on the outflow chemistry of above-drainage coal mines in Appalachia is imperative to constrain mine flow dynamics, the influence of antecedent moisture and precipitation, and the export of DIC and dissolved metals to the environment. 


\subsection{Background}

\subsection{Coal Mine Hydrogeology}

Any below surface mine, at the most basic definition, has the capability to become an aquifer following mine abandonment. Understanding the hydrogeology of the mine systems is imperative to predicting flooding/flow out of the mine and interpret chemical data collected at the outflow. Appalachian coal mines are classified into two basic groups based on their hydrogeology; above-drainage (i.e. updip) and below-drainage (i.e. downdip), based on the structure of the coal (Figure 1).

Coal removal changes the natural, preexisting hydrogeologic conditions of the subsurface in a variety of ways. Coal is removed during mining, creating void space where water may pool and/or flow freely (often through collapsed material and mine waste), similar to a conduitdominated karst system (Shuster and White, 1971; Sahu et al., 2009). Preferential flow pathways make constraining the physical flow regime of updip mines particularly difficult. Coal removal also causes subsidence, resulting in the proliferation and magnification of fractures through the overburden (Figure 2), thereby increasing both the magnitude and rate of recharge entering the subsurface (Light and Donovan, 2015; Donovan and Perry, 2019).

Downdip mines flood as water management pumps in the mine workings are turned off following mine abandonment. This causes recharge water to accumulate in the mine workings, filling the void left by mined coal in a relatively predictable fashion (Younger et al., 2002; Morris et al., 2008). It has been demonstrated that water will seep through intact coal barriers separating mines, further complicating the hydrogeologic interactions of the mine (Light and Donovan, 2015; Mountjoy, 2018). During flooding, water has additional time to interact with overburden, underclay, and spoil material left in the abandoned mine workings. Continual reaction over periods of years to decades while the mine floods causes the eventual discharge to contain high loads of dissolved constituents (Donovan et al., 2003). Given time, downdip outflow chemistry will improve, due largely to a lack of oxygen in the flooded mine, resulting in changed in mineral saturation and equilibria as the mine continues to flood (Donovan et al., 2003).

Updip mines do not require large-scale water management during mining, as water entering the mine generally drips from the roof to the floor, then flows toward the mine adit following dip. Following mine closure, recharge continues to enter through subsidence-related fractures and possible daylighting features or abandoned airshafts (i.e. direct recharge), as well as through the primary matrix porosity (i.e. diffuse recharge). Updip mines usually contain free oxygen, which is necessary for continued oxidation of pyrite (Younger et al., 2002). Research has shown that updip mine chemistry remains impaired for longer time periods than downdip mine waters (Demchak et al., 2004; Mack et al., 2015; Burrows et al., 2015), due largely to the presence of air-filled headspace in the mines. In regions such as the Allegheny Plateau (and much of Appalachia), minor folds and low dip angles make updip mine flow regimes difficult to constrain. Flow generally follows dip, but draining water may pool behind remaining coal pillars or barriers, blocked discharge portals, or drainage may be "short circuited" by preferential flowpaths resulting from coal removal (Sahu et al., 2009). Preferential flowpaths for recharge 
entering the mine can alter the geochemistry in the mine in a variety of ways, including changing the $\mathrm{pH}$ and redox conditions, and increasing discharge volumes and velocities (Figure 3).

\subsection{CMD Chemistry}

Acidity is generated and metals are mobilized by the oxidation of sulfide minerals when exposed to air and water during the mining process (Reaction 1).

$$
\mathrm{FeS}_{2}+3.5 \mathrm{O}_{2}+\mathrm{H}_{2} \mathrm{O} \rightarrow \mathrm{Fe}^{2+}+2 \mathrm{SO}_{4}^{2-}+2 \mathrm{H}^{+} \quad \text { Reaction } 1
$$

This oxidation of pyrite $\left(\mathrm{FeS}_{2}\right)$, a common mineral found in coal bearing strata, produces ferrous iron $\left(\mathrm{Fe}^{2+}\right), \mathrm{SO}_{4}$, and acidity (Stumm and Morgan, 1996), beginning the process of drainage impairment. Reduced $\mathrm{Fe}^{2+}$ in solution can be oxidized in the aqueous system if sufficient acidity and oxygen are present (Reaction 2). The reaction is microbially mediated by Thiobacillus ferrooxidans, particularly at low $\mathrm{pH}$ (Nordstrom, 1982). This reaction is reversible depending on the redox conditions of the system.

$$
\mathrm{Fe}^{2+}+\mathrm{O}_{2}+4 \mathrm{H}^{+} \rightleftharpoons \mathrm{Fe}^{3+}+2 \mathrm{H}_{2} \mathrm{O} \quad \text { Reaction } 2
$$

When sufficient ferric $\left(\mathrm{Fe}^{3+}\right)$ iron is present in solution, pyrite will continue to be oxidized, with approximately eight times more acidity generated than the original oxidation of pyrite (Reaction 3).

$$
\mathrm{FeS}_{2}+14 \mathrm{Fe}^{3+}+8 \mathrm{H}_{2} \mathrm{O} \rightarrow 15 \mathrm{Fe}^{2+}+2 \mathrm{SO}_{4}{ }^{2-}+16 \mathrm{H}^{+} \quad \text { Reaction } 3
$$

$\mathrm{Fe}$ (both $\mathrm{Fe}^{2+}$ and $\mathrm{Fe}^{3+}$ ) released into solution does not always remain in solution. In fact, removing Fe and other CMD associated metals (i.e. $\mathrm{Al}$ and $\mathrm{Mn}$ ) is a primary goal of CMD treatment systems, which use a variety of physical, chemical, and biological means to create favorable conditions for mineral precipitation (Younger et al., 2002; Skousen et al., 2017). A variety of mineral forms are possible, even when only considering Fe. The mineral formed is a function of the solution chemistry, $\mathrm{pH}$, redox conditions, and other environmental factors (Stumm and Morgan, 1996). Hydroxide minerals are a relatively simple form of Fe mineral precipitated by hydrolysis reactions (Reactions 4 and 5).

$$
\begin{array}{lrl}
\mathrm{Fe}^{3+}+3 \mathrm{H}_{2} \mathrm{O} \rightleftharpoons \mathrm{Fe}(\mathrm{OH})_{3}+3 \mathrm{H}^{+} & \text {Reaction 4 } \\
\mathrm{Fe}^{2+}+2 \mathrm{H}_{2} \mathrm{O} \rightleftharpoons \mathrm{Fe}(\mathrm{OH})_{2}+2 \mathrm{H}^{+} & \text {Reaction 5 }
\end{array}
$$

$\mathrm{Al}$ and $\mathrm{Mn}$ are capable of forming similar hydroxide minerals (and many more forms), though the geochemical conditions required for their precipitation vary.

\subsection{Rare Earth Element Chemistry}

The lanthanide series, commonly referred to as rare earth elements (REE), are often present shales throughout North America (Gromet et al., 1984). Yttrium is often included with the lanthanide series for data interpretation, though it is not part of the same period. Yttrium and rare earth elements (YREE) in CMD outflows have been studied for possible extraction from CMD treatment systems for uses in technology and industry (DOE, 2011; Rozelle et al., 2016; Stewart et al., 2017; Hedin et al., 2019). YREE are generally divided into groups based on their atomic weight and which elements are economically critical for industry and defense (Table 1). 




Figure 1: (A) generalized above-drainage/updip mine hydrogeology, where water flows downdip along the mine floor. Updip mines are generally unsaturated. (B) generalized below-drainage/downdip mine hydrogeology, where the mine workings flood if pumping is not maintained. 


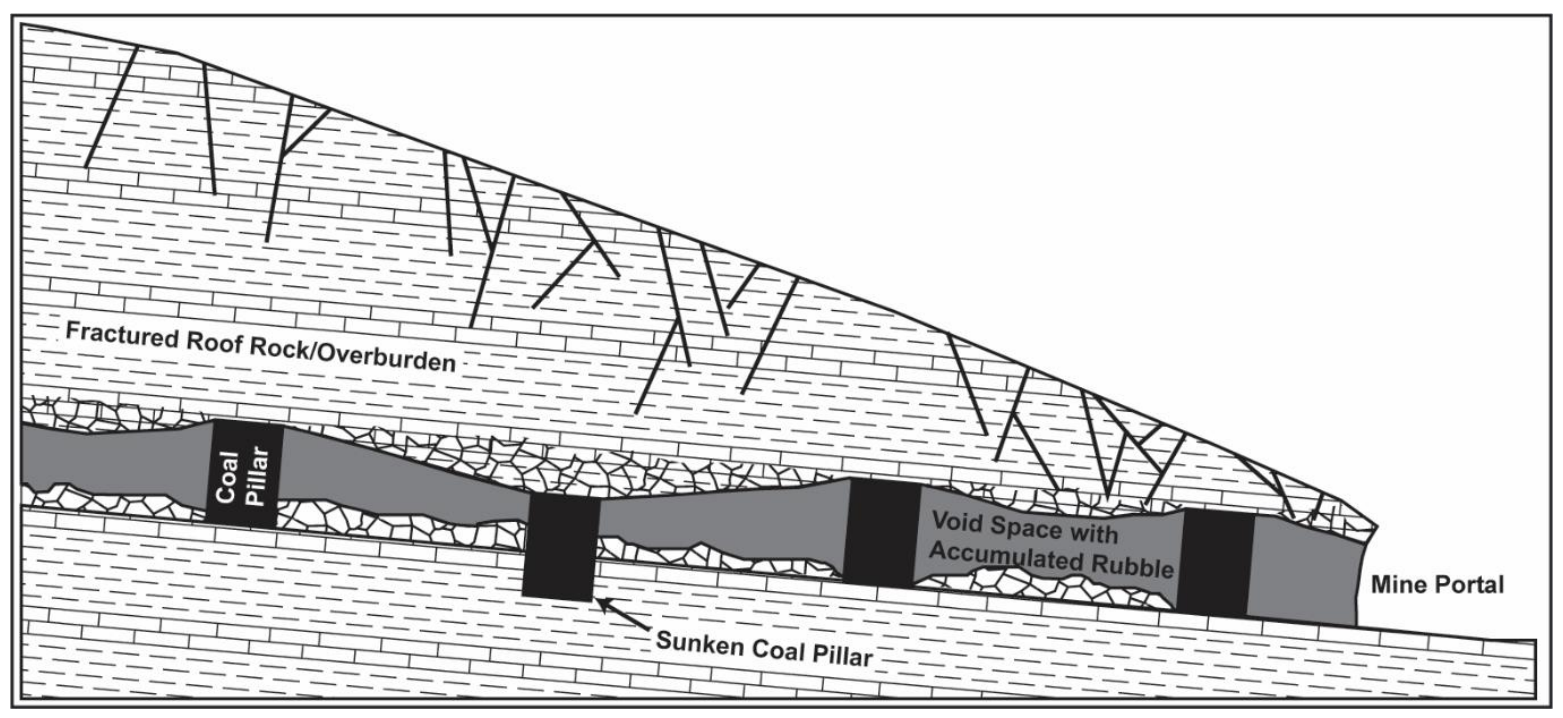

Figure 2: Schematic diagram showing fracture density in mine overburden and post-closure changes to room and pillar mine workings, including sinking coal pillars, roof collapses, and the accumulation of rubble in the mine voids. These factors increase the complexity of updip mine hydrogeology. 


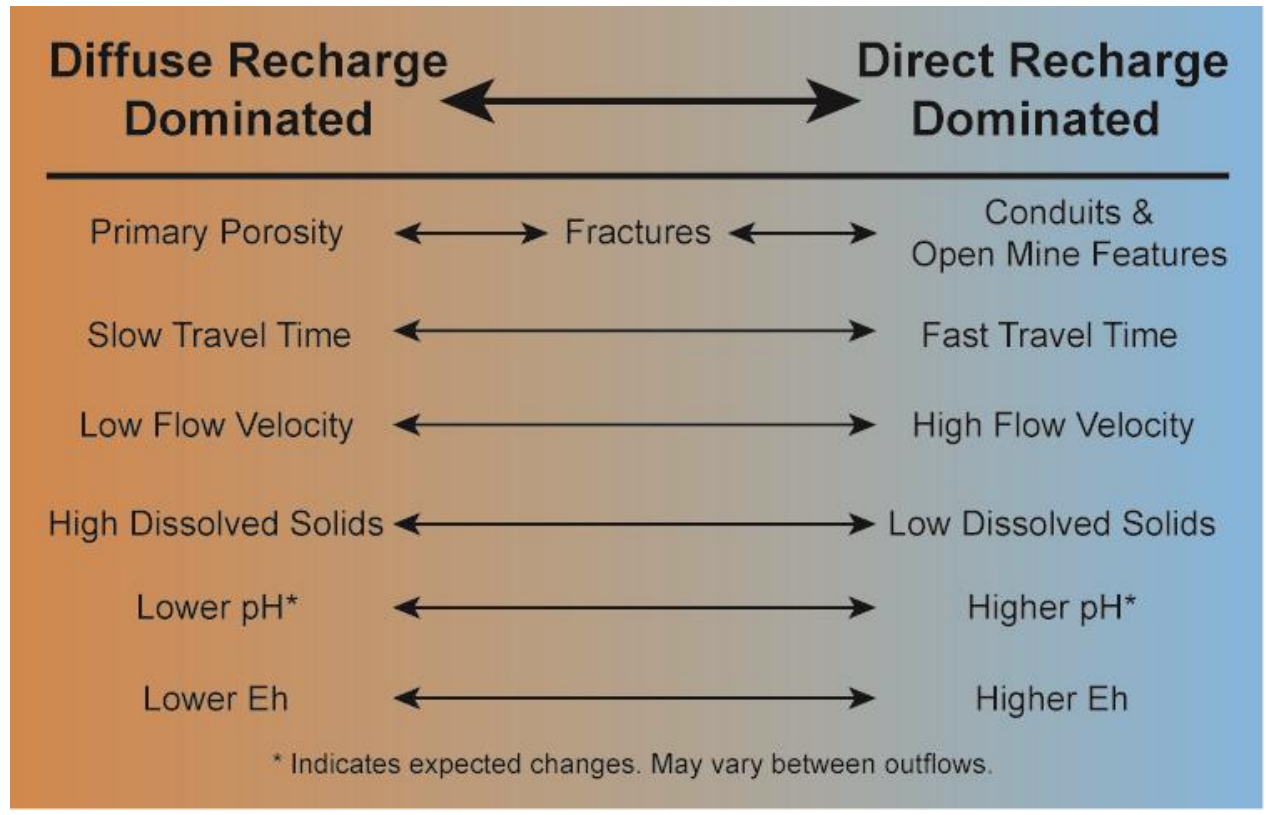

Figure 3: Continuum between diffuse and direct recharge dominated CMD outflow signatures. 
Table 1: Rare earth element groups, based on atomic weight and critical need for energy and defense.

\begin{tabular}{l|l}
\hline Group & Elements \\
\hline Light REE(LREE) & $\mathrm{La}, \mathrm{Ce}, \mathrm{Pr}, \mathrm{Nd}, \mathrm{Sm}$ \\
Middle REE (MREE) & $\mathrm{Eu}, \mathrm{Gd}, \mathrm{Tb}, \mathrm{Dy}, \mathrm{Y}$ \\
Heavy REE (HREE) & $\mathrm{Ho}, \mathrm{Er}, \mathrm{Tm}, \mathrm{Yb}, \mathrm{Lu}$ \\
Energy Critical & $\mathrm{Y}, \mathrm{Nd}, \mathrm{Dy}, \mathrm{Eu}, \mathrm{Tb}$ \\
\hline
\end{tabular}

YREE have been used to "fingerprint" hydrogeologic flow systems in karst (Gill et al., 2018; Berglund et al., 2019), trace mixing patterns in estuaries (Lawrence and Kamber, 2006), and generally understand geochemical processes acting at earth's surface. Several geochemical phenomena within the YREE series allow researchers to make interpretations about the system in question. YREE elements exist mostly in a 3+ oxidation state, with some exceptions like Ce, which can be present in the $3+$ and $4+$ states and can thus provide insight into redox processes (Lawrence et al., 2006). Yttrium is included with REE due to its geochemical similarities to Ho. Variation in the Y/Ho molar ratio can provide insight into sorption processes active in the system, as Y has a lesser affinity for iron oxyhydroxide minerals than do other REE elements (Bau, 1999; Lawrence et al., 2006; Vesper and Smilley, 2010). YREE complexes with $\mathrm{SO}_{4}$ at acidic $\mathrm{pHs}$, with the tendency to behave more conservatively at $\mathrm{pH}<5$. As $\mathrm{pH}$ increases, $\mathrm{CO}_{3}$ becomes the dominant complexing ligand to YREE (Johannesson et al., 1996; Liu et al., 2017). A strength of using lanthanide chemistry in geochemical investigations is that all elements are from the same period, providing a continuous series of elements with increasing atomic mass and decreasing atomic radii.

\section{$2.4 \mathrm{CaCO}_{3}-$ Water System Chemistry}

Carbonate rock units and cements are located adjacent to many Appalachian coal seams (Cardwell et al., 1968). Dissolution of carbonate minerals, aided by both carbonic acid and sulfuric acid weathering, releases DIC into solution. The speciation of DIC in solution is an acid-base reaction, thus governed by $\mathrm{pH}$ (Figure 4), as shown in the following reactions and their corresponding $\mathrm{pKa}$ values at $25^{\circ} \mathrm{C}$ (Stumm and Morgan, 1996).

$$
\begin{array}{lll}
\mathrm{CO}_{2}(\mathrm{~g})+\mathrm{H}_{2} \mathrm{O} \rightleftharpoons \mathrm{H}_{2} \mathrm{CO}_{3}{ }^{*}(\mathrm{aq}) & \mathrm{pK}_{\mathrm{CO} 2}=1.47 & \text { Reaction 6 } \\
\mathrm{H}_{2} \mathrm{CO}_{3}{ }^{*}(\mathrm{aq}) \rightleftharpoons \mathrm{HCO}_{3}-(\mathrm{aq})+\mathrm{H}^{+} & \mathrm{pKa}_{1}=6.35 & \text { Reaction 7 } \\
\mathrm{HCO}_{3}{ }^{-}(\mathrm{aq}) \rightleftharpoons \mathrm{CO}_{3}{ }^{2-}(\mathrm{aq})+\mathrm{H}^{+} & \mathrm{pKa}_{2}=10.33 & \text { Reaction 8 }
\end{array}
$$

At low $\mathrm{pH}$, the dissolution of carbonate minerals by both weak and strong acid weathering (i.e. carbonic and sulfuric acid weathering) often produces dissolved $\mathrm{CO}_{2}$ concentrations greater than expected in equilibrium with atmospheric $\mathrm{CO}_{2}$ (Cravotta, 2008; Vesper et al., 2016), resulting in degassing of $\mathrm{CO}_{2}$ from coal mine discharges. The role of $\mathrm{CO}_{2}$ degassing and DIC in controlling mineral saturation and element speciation is crucial to CMD evolution and treatment, but is not always well understood or documented (Kirby and Cravotta, 2005; Vesper and Smilley, 2010; Gammons et al., 2010). Recent studies have shown $\mathrm{CO}_{2}$ export to the atmosphere is significant 
in magnitude, particularly in the current state of climate studies (Raymond and Oh, 2009; Torres et al., 2014; Ross et al., 2018).

\subsection{Processes Related to Recharge Influencing Mine Drainage Chemistry 2.5.1 Antecedent Moisture Conditions}

A system's response to precipitation is related to the antecedent moisture present within the system (Byrne et al., 2013). One example is the "first flush" caused by efflorescent mineral crusts noted by Nordstrom following the dry season in the western US (Nordstrom, 2009). When moisture is not added to the system in the form of precipitation, evaporation and discharge will cause the net removal of water. This could include the release of metal-laden pore waters and overall lowering of the water table. On the other end of the spectrum, with high antecedent moisture present in the system, dissolved constituents are likely diluted or precipitated by rapidly entering recharge, but higher discharge velocities may mobilize and transport solids within the mine workings.

Byrne et al. (2013) noted changes in chemographic trends of mine drainage impacted streams based on the antecedent moisture prior to storm events. Even when antecedent moisture is present in the system, metals cycle across the storm hydrograph period, suggesting the metals released from the system are sourced by different mechanisms depending on how much moisture is present.

\subsubsection{Mobilization of Stored Water}

Sinking pillars, collapsing overburden, mine waste deposited in the mine during abandonment, and shallow coal bed dip further complicate the flow regime of mines (Figure 2). It is likely water will pool behind blockages, resulting in drainage enriched in dissolved constituents due to increased reaction time with the surrounding minerals. If sufficient volumes of precipitation enters the mine workings, these pools could be mobilized from storage, similar to pool mobilization observed in karst systems (White, 1988).

\subsection{Statement of Problem}

Impaired drainage from mines and exposed sulfide minerals has been noted and studied for decades. However, the widespread nature of these impairments and the wide variety of geologic/hydrogeologic occurrences means there are still unknowns in this field of study, particularly updip mines with complex hydrogeologic conditions. The impacts of flow regime on updip outflows has not been extensively studied in the context of recharge mechanism to the mine. The amount, rate, and source of recharge has the potential to alter geochemical conditions in the mine workings, resulting in changing discharge chemistry and contaminant loading. This work seeks to provide additional insights through the following study objectives:

- Evaluate geochemical changes taking place in updip, shallow coal mines as a result of different recharge conditions (Figure 3);

- Quantify temporal variations in sources and sinks of DIC and metal loading from a shallow, updip mine outflow using a temporally consistent sampling interval;

- Quantify spatial geochemical changes and processes throughout the surface flowpath and treatment system; and,

- Quantify rare earth element removal throughout the passive treatment system. 


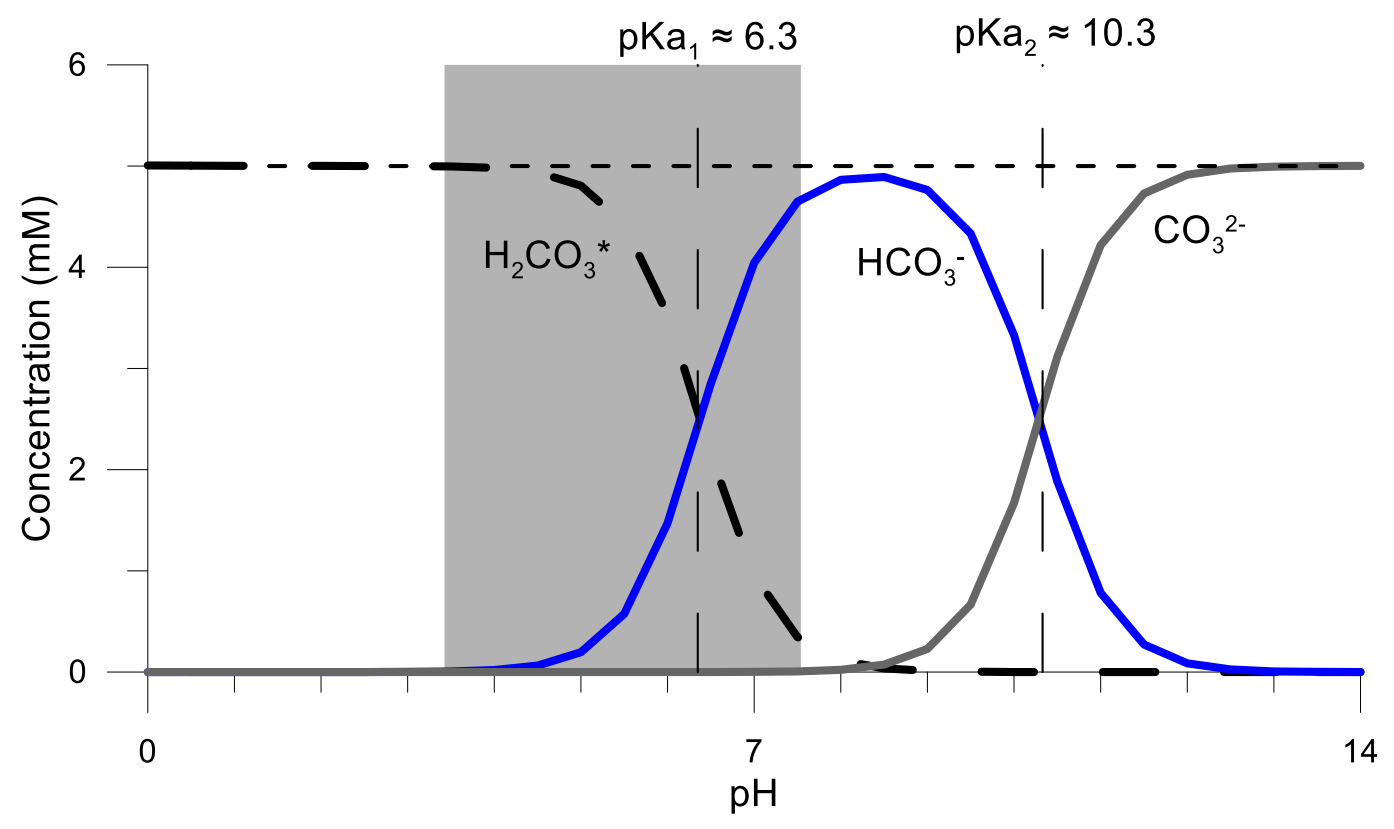

Figure 4: DIC speciation at $20^{\circ} \mathrm{C}$ and total DIC concentration of $5 \mathrm{mmol} / \mathrm{L}$. The shaded portion of the plot shows the approximate $\mathrm{pH}$ range of the study location. 


\subsection{Site Description}

\subsection{Rationale for Site Selection}

This study location has been selected for this research due to its hydrogeologic flow conditions, geologic structure and abundance of previously collected data. Previous investigations have focused on DIC export from the system (Vesper et al., 2016), diel chemical changes of YREE, Fe, Mn, and DIC (Smilley, 2007; Vesper and Smilley, 2010; Riddell, 2015), and the chemical changes resulting from passive treatment system construction at the site (Smilley, 2007). The presence of an observable direct-recharge feature injecting surface water into the mine workings makes it an ideal case study for studying the effect of recharge on CMD chemistry. This study provides a broader insight into the physical flow system within the mine, and its influence on the discharge's chemical variability.

The site is also secured (gated and regularly visited by members of the J.F. Allen Memorial Muzzleloader Club, the primary users of the site), making it ideal for installing instrumentation with little threat of vandalism or theft.

\subsection{Location}

Lambert Run is a tributary to the West Fork River (USGS HUC8 05020002). The West Fork River Watershed drains approximately 2,300 $\mathrm{km}^{2}$ throughout Harrison, Marion, Taylor, Barbour, Upshur, and Lewis Counties, West Virginia (Figure 5). The sub-watershed containing Lambert Run (USGS HUC12 050200020604) has an approximate drainage area of $150 \mathrm{~km}^{2}$ throughout Harrison County. Lambert Run is classified as an impaired stream for constituents related to CMD, including pH and Fe (U.S. Environmental Protection Agency, 2002; Guardians of the West Fork Watershed, 2003).

The study area pertinent to this investigation is in central Harrison County, West Virginia, approximately $5.7 \mathrm{~km}$ northwest of Clarksburg, West Virginia. Previous studies have referred to this site as Muzzle Loader Club mine (MZLC) and "Site 3" by Smilley and the Guardians of the West Fork Watershed, respectively (Guardians of the West Fork Watershed, 2003; Smilley, 2007). The mine discharge is located on the property of the J.F. Allen Memorial Muzzle Loader Club. For brevity and consistency, the study site will be referred to as LRM throughout this document.

\subsection{Geology}

The study area is located on the eastern margin of the Pittsburgh coal basin, a north-northeast trending synclinal basin within parts of southwest Pennsylvania, West Virginia, and southeast Ohio. Bedrock geology in Harrison County includes the Dunkard group, the Monongahela Group, and the Conemaugh Group, all of Pennsylvanian age (Cardwell et al., 1968) (Figure 6). The Pittsburgh coal defines the stratigraphic base of the Monongahela Group and is the primary coal measure mined in the area (Cardwell et al., 1968; WVGES, 2013). The lithology surrounding the Pittsburgh coal (various limestones and shale units) is calcareous and able to generate measurable DIC at the LRM outflow (Smilley, 2007; Vesper and Smilley, 2010).

In the vicinity of the study area, rock units are influenced by minor folds, creating an erratic outcrop pattern for the Pittsburgh coal. LRM is on the eastern limb of the Wolf Summit 


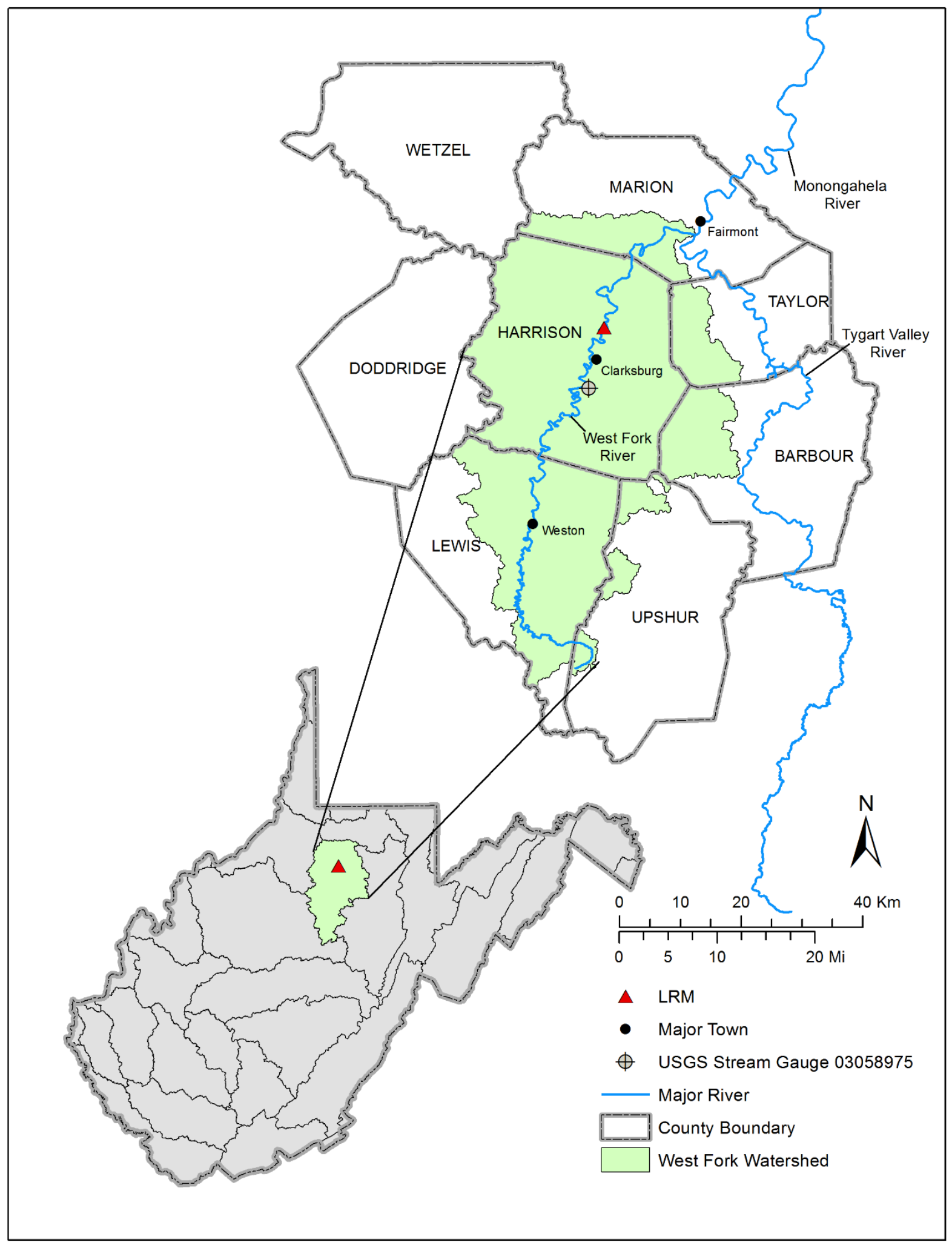

Figure 5: Regional hydrology and geography of the study area. 




Figure 6: Geology of Harrison County, West Virginia. 
anticline, with a calculated dip of approximately $1^{\circ}$ east-northeast along the base of the Pittsburgh coal at the outflow location (WVGES, 2013). The slight dip of the coal classifies the mine draining to LRM as an above-drainage (updip) discharge (Younger et al., 2002; Burrows et al., 2015). At LRM however, the slight dip, remediation of the mine discharge portal and postmining subsidence causes draining water to pool before discharging.

\subsection{History and Remediation}

The mine draining to LRM is known as the Dawson No. 3 Mine of the Commercial Coal and Coke Company (Commercial Coal and Coke Company, 1936). Mine maps dating to 1936 indicate room and pillar features throughout the entirety of the known mine extent (Figure 7). This suggests that mining was near completed in the Dawson No. 3 Mine in 1936. The areal extent of the mine is estimated to be $7.6 \mathrm{~km}^{2}$.

Remediation of the LRM discharge was started by the National Research Center for Coal Energy (NRCCE) in 2006 to reduce metals transported to Lambert Run and the West Fork River.

Remediation included an altered natural wetland, a constructed aerobic wetland, and steel slag leach beds to passively precipitate dissolved metals (Guardians of the West Fork Watershed, 2003; Smilley, 2007). Photographs of the discharge portal during remediation show the mine adit was sealed with a block wall. PVC piping allows water to discharge in a discrete location. After sealing the adit, fill material was placed in front of the wall and discharge pipes (Figure 8).

Recent communication with members of the J.F. Allen Memorial Muzzleloader Club has provided access to a direct recharge feature (i.e. LRM-SHS, swallow hole stream) delivering surface water directly into the mine workings (Figure 7). Club members indicate this recharge feature (possibly a former air shaft into the mine) has existed in some fashion for approximately ten years and has caused notable changes in discharge at the LRM outflow (R. Schuster, personal communication, February 24, 2019). The feature was first noticed after it captured a surface stream, cutting off flow to a pond on the property. The depth of this feature is estimated to be between six and nine meters and receives direct recharge from a pond upstream of the feature. Personal observations have noted increased flow into the recharge feature immediately following large rain events. Club members have also noted increasing ground saturation in recent years, possibly attributed to increased water storage in the mine workings seeping to the surface.

\subsection{Sample Locations}

Samples were collected along the flowpath of the outflow and treatment system (Table 2, Figure 9). Differences between LRM-SHS and LRM-000 indicate geochemical changes brought about as water moves through the mine system, whereas changes between LRM-000 and LRM-172 result from a variety of physical, chemical, and biological changes as water flows through the CMD treatment system. LRM-SHS is a surface water stream which provides insight into the dominant type of recharge entering the mine. When LRM-SHS is not flowing (i.e. the stream is dry or not flowing into the mine), diffuse recharge dominates, when LRM-SHS is flowing, direct recharge dominates (Figure 3). During periods where LRM-SHS was not flowing or dry, samples were not collected there. 


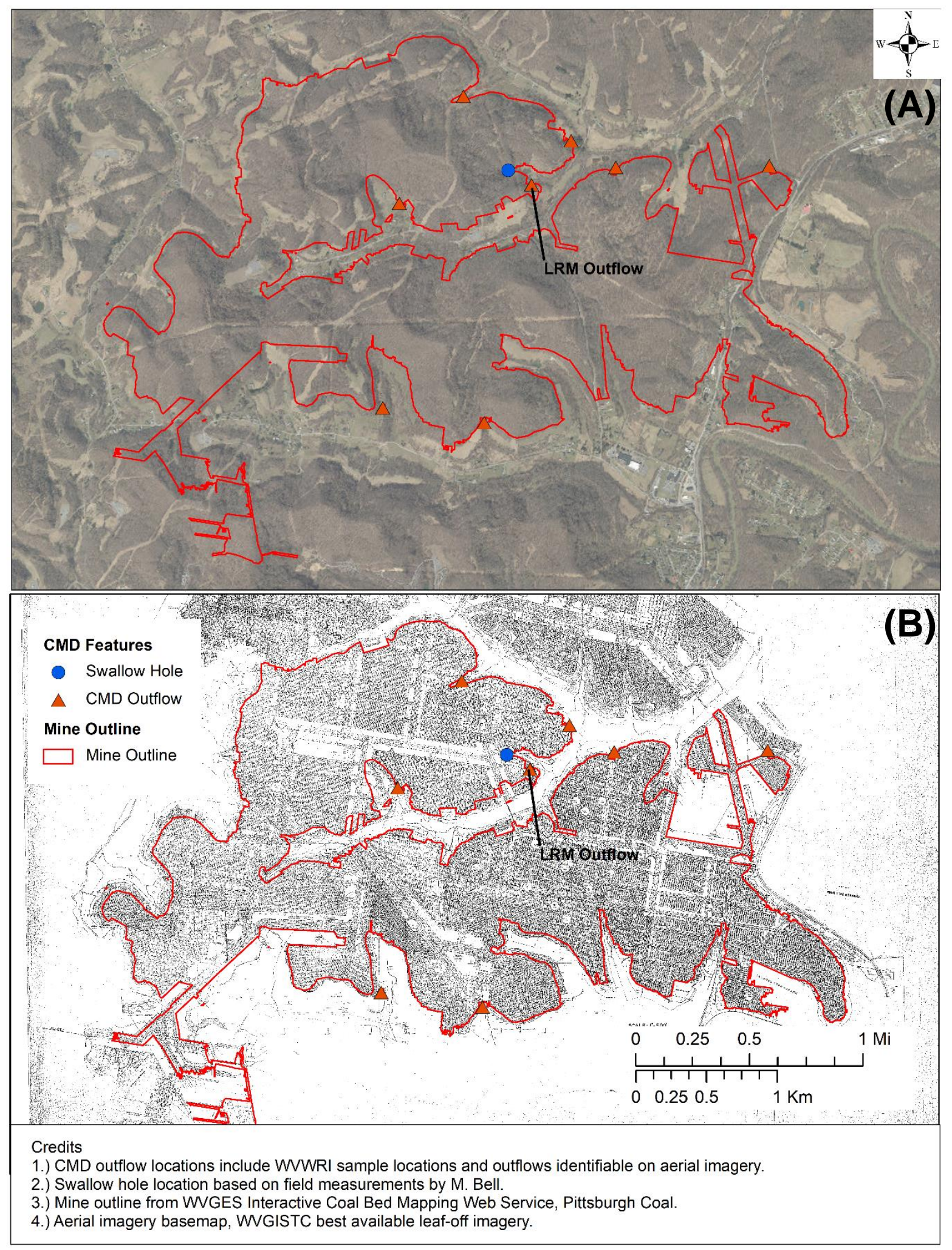

Figure 7: Coal mine drainage outflow locations draining the Dawson No. 3 mine shown on (A) recent leaf-off aerial imagery, and (B)1936 Dawson No. 3 mine map. 


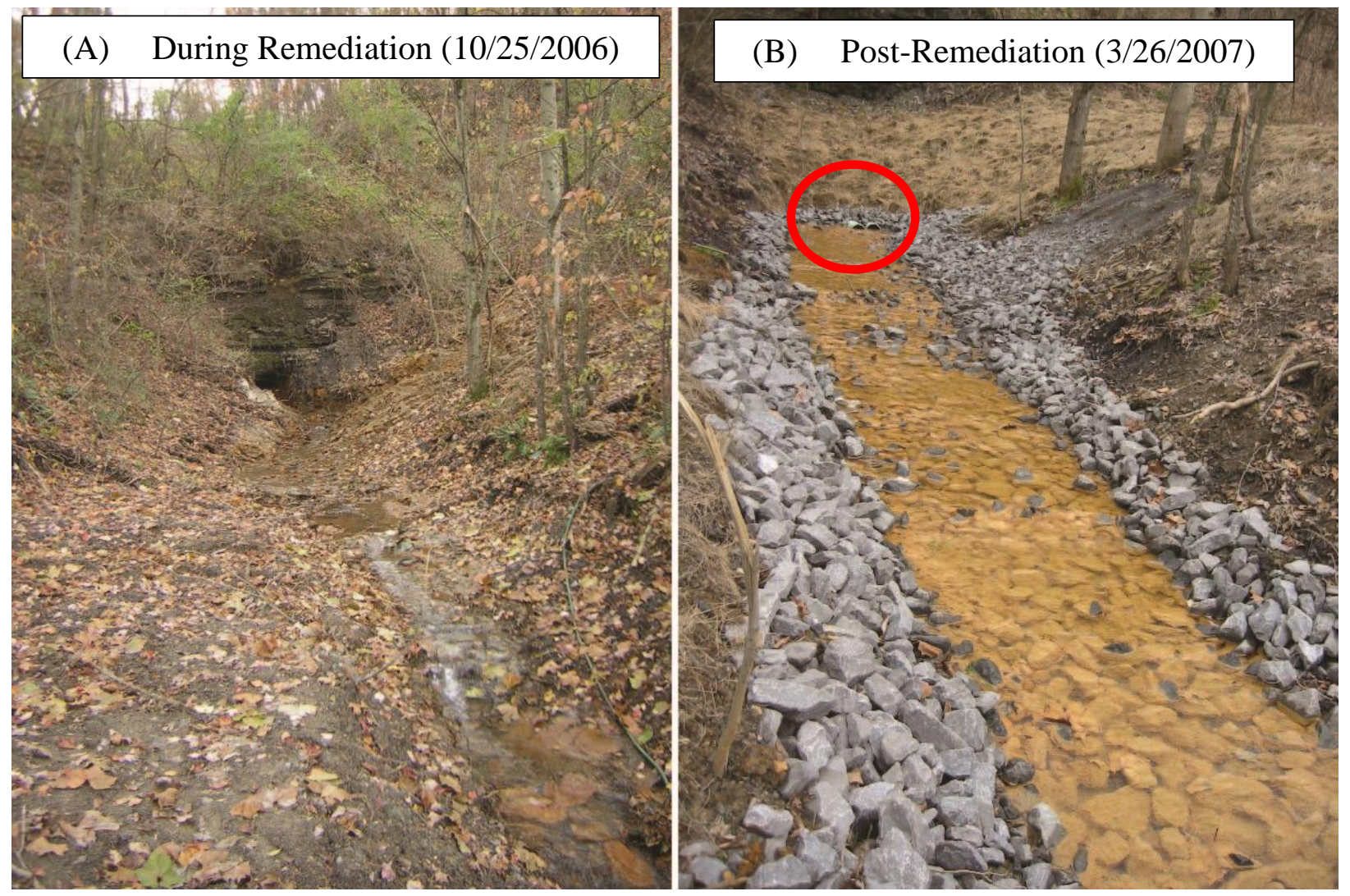

Figure 8: LRM mine portal (A) during remediation and (B) post-remediation. Note two plastic outflow pipes circled in photo B. Photo A courtesy of John Eleyette, photo B courtesy of Mike Smilley. 
Table 2: Sample location codes and descriptions.

\begin{tabular}{lcl}
\hline $\begin{array}{l}\text { Sample Location } \\
\text { Code }\end{array}$ & $\begin{array}{c}\text { Distance from } \\
\text { Mine Portal }\end{array}$ & Location Description \\
\hline LRM-SHS & N/A & Stream entering mine through swallow hole \\
LRM-000 & $0 \mathrm{~m}$ & Mine portal, samples collected at discharge pipe \\
LRM-010 & $10 \mathrm{~m}$ & Within limestone-lined channel \\
LRM-050 & $50 \mathrm{~m}$ & End of limestone-lined channel \\
LRM-172 & $172 \mathrm{~m}$ & End of altered natural wetland \\
\hline
\end{tabular}




\section{LRM Sample Locations}

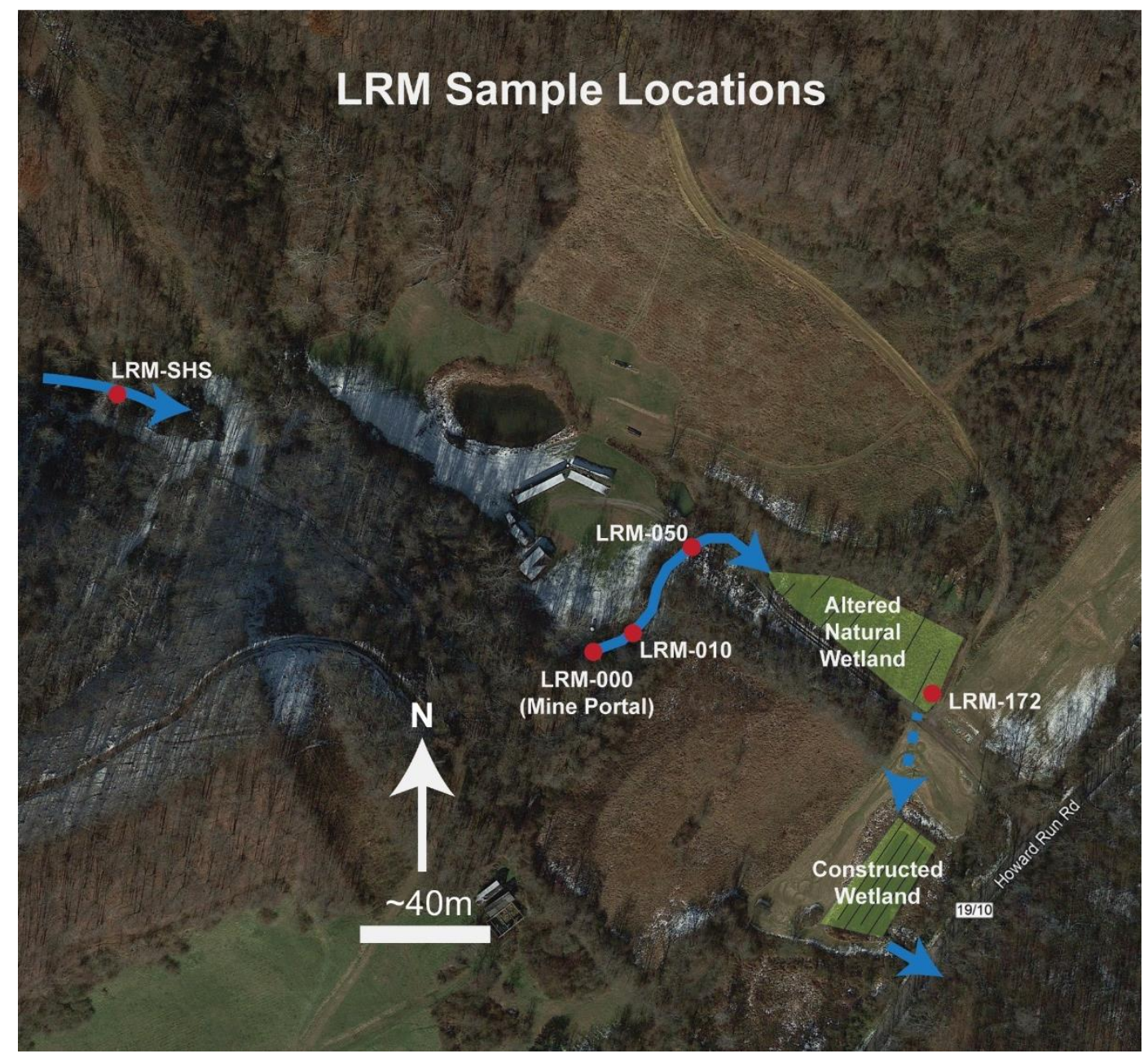

Figure 9: LRM sample locations and site features. 


\subsection{Methods}

\subsection{Mine Features and Extent}

Mine maps of the area were obtained from the West Virginia Geological and Economic Survey (WVGES) Mine Information Database System (WVGES, 2019). The mine map ID was determined from the WVGES Coal Bed Mapping Project interactive map for the Pittsburgh coal (WVGES, 2013). The 1936 map for the Dawson No. 3 mine (Commercial Coal and Coke Company, 1936) was downloaded and georeferenced using ArcGIS software. Additional GIS files were obtained from the WVGES, including mine outline polygons, coal bed elevation raster and coal thickness raster. Low-resolution elevation data for the site was supplemented by field surveys of notable features like LRM-SHS and LRM-000.

Locations of sampled CMD outflows and treatment systems near LRM were obtained from West Virginia Water Research Institute (WVWRI) staff. Additional unsampled outflows were identified manually by their orange color on recent leaf-off aerial imagery.

\subsection{Precipitation and Potential Evaporation}

USGS stream gauge 03058975 on the West Fork River near Mount Clare, West Virginia collects river stage and rainfall data every 15 minutes. This stream gauge is approximately $8 \mathrm{~km}$ south of LRM (Figure 5). Precipitation data were used to quantify the antecedent moisture conditions of the area. In addition to USGS gauge 03058975, daily precipitation and temperature records were obtained from a long-running Weather Underground station at the North Central West Virginia Airport, approximately $12.5 \mathrm{~km}$ east of the site (Weather Underground, 2020). Using precipitation data from USGS gauge 03058975 and daily temperature data from the North Central West Virginia Airport Weather Underground station, potential evapotranspiration for each month was calculated using the equation from Thornthwaite (1948). Using the average daily temperature for the month, average day length, and the number of days in the month, potential evapotranspiration can be estimated for a given area. Potential evapotranspiration was then subtracted from total monthly precipitation to determine monthly precipitation excess or deficit.

\subsection{Field Methods}

For the purpose of this study, field methods are defined as any measurement which are collected continuously or near-instantly with field equipment or meters (Table 3).

\subsubsection{Continuous Data Loggers}

Continuous (readings every 15 minutes) conductivity and temperature data were collected at LRM-010 since 5/21/2019 using a HOBO U24-001 freshwater conductivity data logger (Onset Computer Corporation, Bourne, MA). LRM-010 was chosen to reduce interference with mineral precipitates early in the flowpath. Temperature and conductivity at LRM-000 and LRM-010 are within $2 \%$ of one another, on average, so trends at LRM-010 are reflective of changes at LRM000. At the time of each offload, measurements with calibrated YSI meters are taken to ensure correct logger function. The conductivity of water is correlated to temperature. Specific conductance (SC) corrects and reports conductivity as if it were measured at $25^{\circ} \mathrm{C}$. Continuous conductivity data at LRM-010 were converted to $\mathrm{SC}$ using a $2.1 \%$ per ${ }^{\circ} \mathrm{C}$ linear temperature correction. This correction provided consistent agreement with YSI meter data within $\pm 10 \%$ of 
the calculated SC value from data loggers. Continuous conductivity and temperature data were collected at LRM-SHS since 8/8/2019, with a data gap between 10/3/2019 and 10/18/2019 for logger maintenance. At both LRM-010 and LRM-SHS, each time the logger was offloaded a hydroxylamine hydrochloride solution and deionized water rinse were used to clean precipitates from the logger surface.

\subsubsection{Field Measurements}

During field events, temperature, $\mathrm{pH}, \mathrm{SC}$, and dissolved oxygen (DO) were measured using YSI handheld water quality meters. Temperature, $\mathrm{pH}$, and $\mathrm{SC}$ were measured using a YSI Professional Plus Multiparameter instrument, which was calibrated at the start of each field event. Calibration included a $1.413 \mathrm{mS} / \mathrm{cm} \mathrm{KCl} \mathrm{SC} \mathrm{standard,} \mathrm{and} \mathrm{standard} 4.00$ and $7.00 \mathrm{pH}$ buffers. DO was measured using a YSI ProODO instrument, which was also calibrated at the start of each field event to $100 \%$ DO saturation based on barometric pressure.

Field DIC and $\mathrm{CO}_{2}$ were measured using a CarboQC commercial beverage carbonation meter (Anton Paar, Graz, Austria) following methodology by Vesper and Edenborn (2012) and Vesper et al. (2015). For both DIC and $\mathrm{CO}_{2}$ measurements, $140-\mathrm{mL}$ luer lock syringes were filled and had the plunger attached below the water surface (when stream conditions allowed) to minimize degassing of the sample. Any trapped air was expelled through the syringe tip prior to attachment to the CarboQC. Samples were injected directly into the CarboQC. Approximately $80 \mathrm{~mL}$ of sample was used to rinse the meter apparatus, the remaining volume was then used to measure dissolved $\mathrm{CO}_{2}$ in the sample. To measure total DIC, $10 \mathrm{~mL}$ of $\mathrm{CO}_{2}$ ionic strength adjuster solution (Thermo Fisher Scientific, Waltham, MA, Catalog \#950210) was directly injected into $100 \mathrm{~mL}$ of sample. After mixing thoroughly, samples were injected using the same procedure stated previously. Temperature and $\mathrm{pH}$ of the final buffered solution was then measured to ensure complete conversion of DIC to $\mathrm{H}_{2} \mathrm{CO}_{3}{ }^{*}$ and allow calculation of total DIC in $\mathrm{mol} / \mathrm{L}$ using Equation 1 (Vesper et al., 2015).

$$
D I C=1.1 *\left[a_{\mathrm{H} 2 \mathrm{CO} 3}\left[\frac{1}{\gamma_{\mathrm{H} 2 \mathrm{CO} 3}}+\frac{K_{1}}{\gamma_{\mathrm{HCO} 3} a_{\mathrm{H}}}+\frac{K_{1} K_{2}}{\gamma_{\mathrm{CO}_{3} a_{\mathrm{H}}}}\right]\right] \quad \text { Equation } 1
$$

Where $\mathrm{K}_{1}$ and $\mathrm{K}_{2}$ are the first and second dissociation constants for carbonic acid (Reactions 7 and 8), $\gamma$ is the activity coefficient for the specified species, and $\alpha$ is the activity of the specified species in mol/L. Temperature corrections for $\mathrm{K}$ values were calculated following Plummer and Busenberg (1982). Each sample was measured three times and averaged for the final result. Sample syringes were rinsed thoroughly with sample water between each replicate and sample location. Field measurements were collected every two weeks, on average, throughout the sampling period.

\subsubsection{Discharge}

Conditions at the field site have made consistent, reproducible discharge measurements difficult using most standard methods. Discharge measurements were collected using a USGS pygmy current meter with a cat's-whisker-contact chamber and wading rod to determine velocity and water depth within the throat of a pre-rated portable cutthroat flume (Baski, Inc., Englewood, $\mathrm{CO})$. The number of revolutions per minute was measured three times using the six-tenths-depth 
method. The triplicate revolution measurements were averaged for the final result. Velocity was calculated using Equation 2 (Turnipseed and Sauer, 2010).

$$
V=0.9604 R+0.0312
$$

Equation 2

Where $\mathrm{R}$ is the number of revolutions per second, and $\mathrm{V}$ is velocity in feet per second. Discharge was calculated using the velocity, water depth in the flume throat, and flume throat width. Discharge was measured during each sampling event.

\subsection{Laboratory Measurements}

Chemical methods for this study were performed in a laboratory setting (Table 3 and Table 4).

Filtered samples to determine cation concentrations were collected in 125-mL HDPE bottles and preserved with $1 \mathrm{~mL}$ of trace metal grade nitric acid. Samples were passed through a $0.45-\mu \mathrm{m}$ torturous path Whatman syringe filter. Analysis was performed by inductively coupled plasma mass spectrometry (ICP-MS) at Activation Laboratories (Ancaster, Ontario) using standard methodologies.

Samples for anion analysis were field filtered through a $0.45-\mu \mathrm{m}$ torturous path Whatman syringe filter. Samples were analyzed at the National Research Center for Coal and Energy (NRCCE) laboratory (Morgantown, WV) for $\mathrm{Cl}$ and $\mathrm{SO}_{4}$ using EPA method 300.0 on a Dionex ion chromatography (IC) system.

$\delta^{18} \mathrm{O}$ and $\delta^{2} \mathrm{H}$ samples were sent to the University of Kentucky Stable Isotope Laboratory (Lexington, KY) for analysis using a Los Gatos Research T-LWIA-45-EP laser absorption spectrometer. Samples were field filtered to $0.45-\mu \mathrm{m}$ using torturous path Whatman syringe filters into 30-mL HDPE bottles. Sample bottles were sealed tightly with the lids taped on prior to shipping to prevent evaporation from the bottle. Duplicate samples were within $\pm 0.1 \%$ and $\pm 0.6 \%$ VSMOW for $\delta^{18} \mathrm{O}$ and $\delta^{2} \mathrm{H}$, respectively.

$\delta^{13} C_{\text {DIC }}$ samples were sent to the West Virginia University IsoBioGeM Laboratory (Morgantown, WV) for analysis using a Finnegan Delta Advantage continuous-flow isotope ratio mass spectrometer (CF-IRMS). Samples were field filtered to $0.45-\mu \mathrm{m}$ using nylon torturous path Whatman syringe filters into $10-\mathrm{mL}$ Wheaton glass vials. Filtered samples were preserved with two drops of benzalkonium chloride (BAC) to sterilize the samples of any living organisms. Samples were then sealed using Teflon septa and crimped aluminum caps to prevent degassing. Laboratory samples were collected every two weeks throughout the sampling period, on average. 
Table 3: Sampling intervals and method summary.

\begin{tabular}{|c|c|c|c|c|}
\hline Group & Parameter & $\begin{array}{l}\text { Type } \\
\text { Code }\end{array}$ & Sampling Interval & Method/Source \\
\hline \multirow{2}{*}{$\begin{array}{l}\text { Download- } \\
\text { able Data }\end{array}$} & Precipitation & $\mathrm{D}$ & 15 minutes & USGS Gauge 03058975 \\
\hline & Temperature & $\mathrm{D}$ & Daily & $\begin{array}{l}\text { North Central West Virginia } \\
\text { Airport Weather Underground } \\
\text { Station }\end{array}$ \\
\hline \multirow{2}{*}{$\begin{array}{c}\text { Continuous } \\
\text { Field Data }\end{array}$} & Conductivity & $\mathrm{L}$ & 15 minutes & $\begin{array}{l}\text { HOBO U24-001 Logger } \\
\text { YSI Pro Plus Meter }\end{array}$ \\
\hline & Temperature & $\mathrm{L}$ & 15 minutes & $\begin{array}{l}\text { HOBO U24-001 Logger } \\
\text { YSI Pro Plus Meter }\end{array}$ \\
\hline \multirow{5}{*}{$\begin{array}{l}\text { Field } \\
\text { Analysis }\end{array}$} & $\begin{array}{l}\text { Temperature, } \\
\text { pH, SC }\end{array}$ & $\mathrm{M}$ & Every 2 weeks & $\begin{array}{c}\text { YSI ProPlus Multiparameter } \\
\text { Meter }\end{array}$ \\
\hline & DO & M & Every 2 weeks & YSI ProODO Meter \\
\hline & Discharge & $\mathrm{M}$ & Every 2 weeks & $\begin{array}{c}\text { Pygmy current meter } \\
\text { (measurement taken in throat of } \\
\text { cutthroat flume*) }\end{array}$ \\
\hline & Dissolved $\mathrm{CO}_{2}$ & FA & Every 2 weeks & $\begin{array}{l}\text { CarboQC Meter, per Vesper et } \\
\text { al., } 2015\end{array}$ \\
\hline & DIC & FA & Every 2 weeks & $\begin{array}{c}\text { CarboQC Meter, per Vesper et } \\
\text { al., } 2015\end{array}$ \\
\hline \multirow{4}{*}{$\begin{array}{c}\text { Laboratory } \\
\text { Analysis }\end{array}$} & Cations & LA & Every 2 weeks & $\begin{array}{l}\text { Inductively coupled plasma } \\
\text { mass spectrometry (ICP-MS) }\end{array}$ \\
\hline & Anions & LA & Every 2 weeks & $\begin{array}{c}\text { EPA method } 300.0 \\
\text { Dionex ion chromatography (IC) } \\
\text { system }\end{array}$ \\
\hline & $\delta^{13} \mathrm{C}_{\mathrm{DIC}}$ & LA & Every 2 weeks & $\begin{array}{l}\text { Finnegan Delta Advantage CF- } \\
\text { IRMS with Gasbench Device }\end{array}$ \\
\hline & $\delta^{18} \mathrm{O}$ and $\delta^{2} \mathrm{H}$ & LA & Every 2 weeks & $\begin{array}{l}\text { Los Gatos Research T-LWIA- } \\
\text { 45-EP laser absorption } \\
\text { spectrometer }\end{array}$ \\
\hline
\end{tabular}

Notes: D, downloadable data; $M$, data logged using a handheld meter; $L$, data logged using a continuous data logger; FA, field analyzed parameters; LA, laboratory analyzed parameters; $C$, calculated parameters; SC, specific conductance; $D O$, dissolved oxygen; DIC, dissolved inorganic carbon.

*flow not sufficient for open channel flow conditions in the cutthroat flume, therefore pygmy meter measurements of water depth and velocity were used to calculate the discharge through the flume throat 
Table 4: Sample collection and handling summary.

\begin{tabular}{|c|c|c|c|c|c|}
\hline Analyte & Volume & $\begin{array}{l}\text { Container } \\
\text { Type }\end{array}$ & Sample Handling & $\begin{array}{c}\text { Target } \\
\text { Holding } \\
\text { Time } \\
\end{array}$ & Laboratory \\
\hline Cations & $1 \times 125-\mathrm{mL}$ & HDPE & $\begin{array}{c}0.45-\mu \mathrm{m} \text { filter, } 1 \mathrm{~mL} \\
\text { trace metal grade } \mathrm{HNO}_{3} \\
\text { added, stored at } \leq 4^{\circ} \mathrm{C}\end{array}$ & 180 days & $\begin{array}{c}\text { Activation } \\
\text { Laboratories } \\
\text { Ontario, Canada }\end{array}$ \\
\hline Anions & $1 \times 125-\mathrm{mL}$ & HDPE & $\begin{array}{l}0.45-\mu \mathrm{m} \text { filter, stored at } \\
\leq 4^{\circ} \mathrm{C}\end{array}$ & 28 days & $\begin{array}{c}\text { NRCCE } \\
\text { Morgantown, WV }\end{array}$ \\
\hline$\delta^{13} \mathrm{C}_{\text {DIC }}$ & $1 \times 10-\mathrm{mL}$ & clear glass & $\begin{array}{l}0.45-\mu \mathrm{m} \text { nylon filter, } \\
2 \text { drops benzalkonium } \\
\text { chloride added, lid and } \\
\text { septa crimped on to bottle } \\
\text { with no headspace, stored } \\
\text { at } \leq 4^{\circ} \mathrm{C}\end{array}$ & 30 days & $\begin{array}{c}\text { IsoBioGeM } \\
\text { Laboratory } \\
\text { Morgantown, WV }\end{array}$ \\
\hline$\delta^{18} \mathrm{O}$ and $\delta^{2} \mathrm{H}$ & $1 \times 30-\mathrm{mL}$ & HDPE & $\begin{array}{c}0.45-\mu \mathrm{m} \text { filter, lids taped } \\
\text { prior to shipping, stored } \\
\text { at } \leq 4^{\circ} \mathrm{C}\end{array}$ & 30 days & $\begin{array}{c}\text { University of } \\
\text { Kentucky Stable } \\
\text { Isotope Laboratory } \\
\text { Lexington, KY }\end{array}$ \\
\hline
\end{tabular}

Notes: HDPE, high density polyethylene (i.e. plastic); NRCCE, National Research Center for Coal and Energy; All samples to be stored at $\leq 4^{\circ} \mathrm{C}$, but not frozen.

\subsection{Calculations}

Calculations discussed below were performed using data compiled from the field and laboratory methods.

\subsubsection{Geochemical Modeling}

PHREEQC geochemical modeling software (Parkhurst and Appelo, 2013) was used to further analyze chemical data collected throughout the study. Calculations performed included ionic strength, charge balance, mineral saturation, and element speciation/complexation. The Lawrence Livermore National Laboratory (LLNL) database was chosen for geochemical calculations, with several modifications of incorrect formation constant $\left(\mathrm{K}_{\mathrm{f}}\right)$ values for YREE complexes (Liu et al., 2017, Appendix C).

\subsubsection{Potential Acidity}

Using methodology discussed by Kirby and Cravotta, the total acid producing capacity of the mine outflow can be calculated using $\mathrm{pH}$ and concentration data for $\mathrm{Fe}, \mathrm{Al}$, and $\mathrm{Mn}$ (Kirby and Cravotta, 2005). The following equation was used to calculated acidity in eq/L using molar concentrations of hydrolysable metals as inputs (Kirby and Cravotta, 2005). 


$$
\text { Potential Acidity }_{\text {calc }}=10^{-p H}+3\left[\mathrm{Fe}^{3+}\right]+2\left[\mathrm{Fe}^{2+}\right]+3\left[\mathrm{Al}^{3+}\right]+2\left[\mathrm{Mn}^{2+}\right] \quad \text { Equation } 3
$$

Dissolved $\mathrm{Fe}$ is largely in the $\mathrm{Fe}^{2+}$ form at LRM, therefore all $\mathrm{Fe}$ is assumed to be $\mathrm{Fe}^{2+}$ for the purpose of calculating acidity.

\subsubsection{Carbonate Alkalinity}

Carbonate alkalinity was calculated for each sample using measured DIC concentration and major element chemistry. The sample $\mathrm{pH}$, temperature, and concentrations of $\mathrm{DIC}, \mathrm{Ca}, \mathrm{Mg}, \mathrm{Fe}$, $\mathrm{Mn}, \mathrm{Sr}, \mathrm{Na}, \mathrm{Cl}$, and $\mathrm{SO}_{4}$ were modeled using PHREEQC geochemical modeling software. Calculations performed using this select input did not significantly change the charge balance error (CBE) or speciation for all samples, and thus deemed sufficient to accurately represent the water chemistry. All dissolved species containing $\mathrm{HCO}_{3}$ and $\mathrm{CO}_{3}$ species were then exported and used to calculate carbonate alkalinity (Equation 4).

$$
\text { Carbonate Alkalinity }_{\text {calc }}=1\left[\mathrm{HCO}_{3}{ }^{-}{ }_{\text {Total }}\right]+2\left[\mathrm{CO}_{3}{ }^{2-}{ }_{\text {Total }}\right] \quad \text { Equation } 4
$$

Where $\mathrm{HCO}_{3}{ }^{-}$Total is the sum of the concentrations of $\mathrm{HCO}_{3}$ and complexes including $\mathrm{HCO}_{3}$, and $\mathrm{CO}_{3}{ }^{2-}$ Total is the sum of the concentrations of $\mathrm{CO}_{3}$ and $\mathrm{CO}_{3}$ complexes. Concentration inputs are in $\mathrm{mol} / \mathrm{L}$, and the resulting alkalinity is in eq/L.

\subsection{Quality Control (QC)}

Throughout the sampling period, duplicate samples and blank samples were collected and analyzed at regular intervals (roughly a 1:10 duplicate/blank to sample ratio). Appendices D and E provide discussion of duplicate samples and blank results. When calculating percent removal of a parameter, only the sample was included, not the duplicate. When average concentrations were calculated, duplicates were included.

Charge balance error (CBE) was calculated with all available geochemical data using PHREEQC (Equation 5), where cation and anion units are eq/L.

$$
C B E=\left(\frac{\text { Ecations }-\mid \text { Eanions } \mid}{\text { Ecations }+\mid \text { Eanions } \mid}\right) * 100 \quad \text { Equation } 5
$$

The maximum charge balance error for all samples was $12.5 \%$. All samples were included for results and interpretation. 


\subsection{Results}

\subsection{Mine Hydrogeology}

Based on digitized mine outlines, the Dawson No. 3 Mine is approximately $7.6 \mathrm{~km}^{2}$. According to the 1936 mine map, room and pillar mining was the predominant technique used for coal extraction (Figure 7). A total of eight known CMD outflows drain the Dawson No. 3 Mine (Figure 10). LRM-SHS is located near the edge of the mapped mine workings, approximately eight meters higher in elevation than LRM-000. It is possible there are more direct recharge features, though the presence or location of any additional features is currently unknown.

Coal bed elevation data (Figure 10) indicates a hydrologic divide in the mine workings, assuming flow occurs along dip. The hydrologic divide causes approximately $2.3 \mathrm{~km}^{2}$ of the total mine to drain toward LRM. The difference in elevation between LRM-SHS and LRM-000 and shallow coal bed dip suggests a portion of recharge from LRM-SHS likely drains to LRM000 .

Draining water likely pools prior to discharging from the subsurface, as suggested by LRM-000 flowing year-round, despite seasonal dry periods. Minor pools are possible within the Dawson No. 3 Mine, behind blockages and at elevations below known outflows.

\subsection{Precipitation and Potential Evaporation}

Based on the last five years of rainfall and air temperature data, LRM occasionally has precipitation deficits (more potential evaporation than precipitation) during late spring and summer months. 2019 was an especially dry year, with a continuous precipitation deficit from May to September (Figure 11).

In September 2019, the stream at LRM-SHS dried up due to the extended period of deficit precipitation. During this period, less recharge entered the mine system. The recharge rate also decreases as diffuse recharge becomes more dominant (Figure 3).

\subsection{Field Parameters}

\subsubsection{Continuous Data}

\section{Continuous Temperature}

Temperature and conductivity were measured every 15 minutes at LRM-010 and LRM-SHS throughout the study period. At LRM-010, temperature varied between 10.8 and $15.2^{\circ} \mathrm{C}$. Water temperature at LRM-SHS was more variable and tied more closely to seasonal changes, ranging from 2.1 to $30.4^{\circ} \mathrm{C}$.

The consistent temperature at LRM-010 (Figure 12, mean $=13.2^{\circ} \mathrm{C}$, standard deviation $[\mathrm{SD}]=$ $0.54^{\circ} \mathrm{C}$ ) suggests recharge water is retained long enough to become thermally equilibrated to the subsurface temperature. In 2019, the mean annual temperature in Clarksburg, West Virginia was $13.7^{\circ} \mathrm{C}$ (NOAA, 2020). The largest temperature deviations at LRM-010 occur during precipitation events, potentially causing recharge to move through the system before thermal equilibration can take place. There are several possible explanations for the minor deviations in 


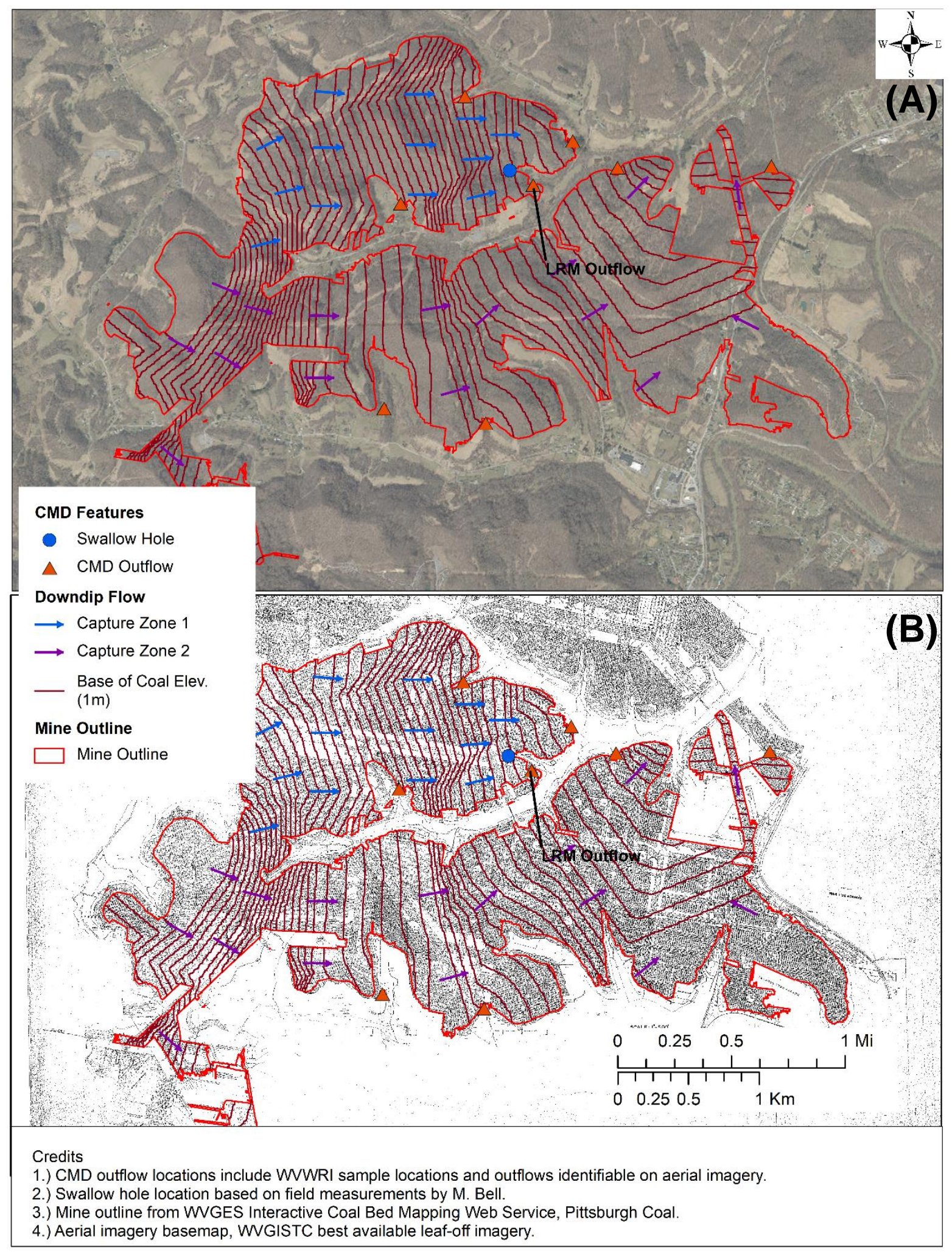

Figure 10: Coal bed elevation contours and inferred capture zones based on downdip flow, shown on (A) recent leaf-off aerial imagery and (B) 1936 Dawson No. 3 mine map. 


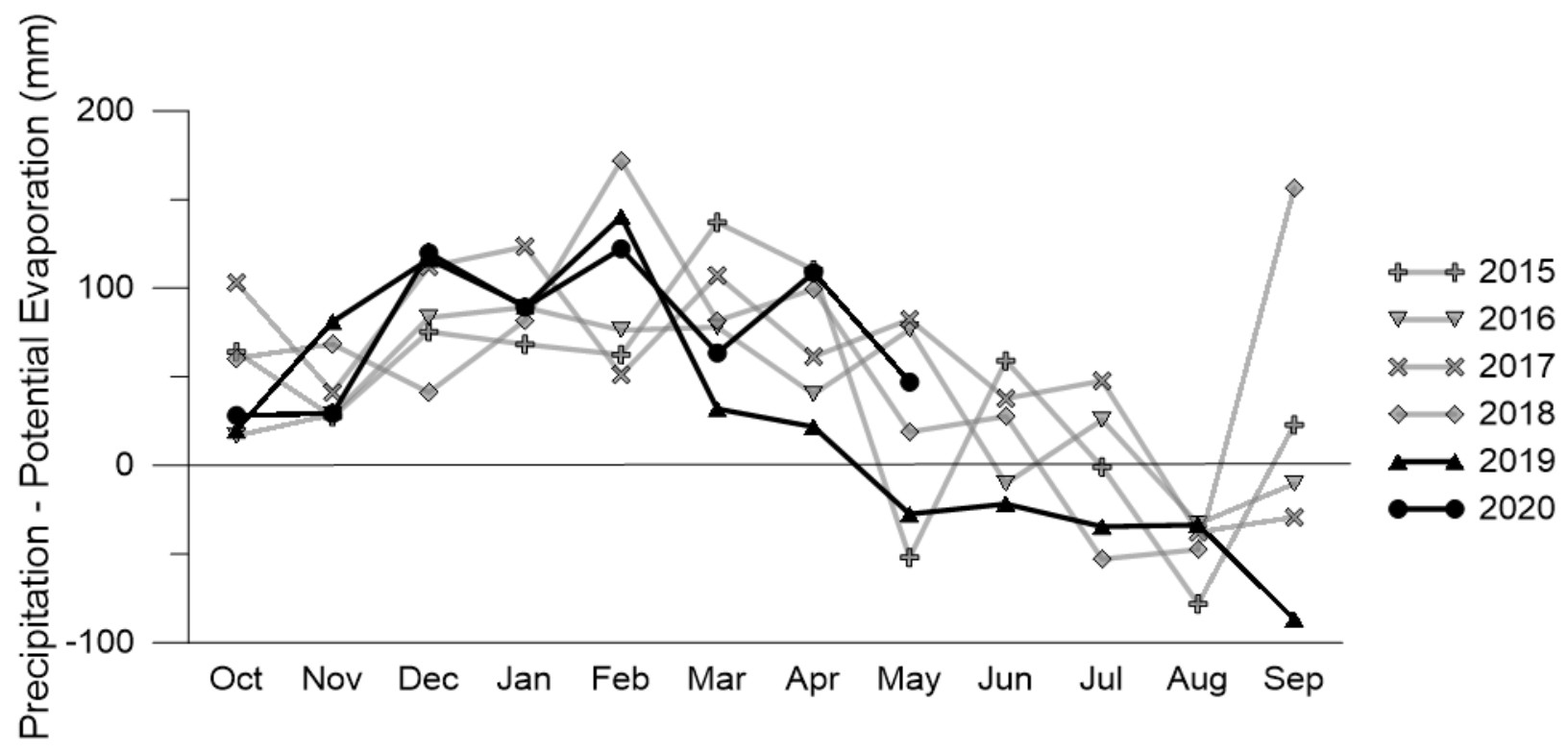

Figure 11: Monthly net precipitation at LRM for each water year since 2015, calculated using Thornthwaite's equation (1948). Note the prolonged period of deficit precipitation in 2019. 


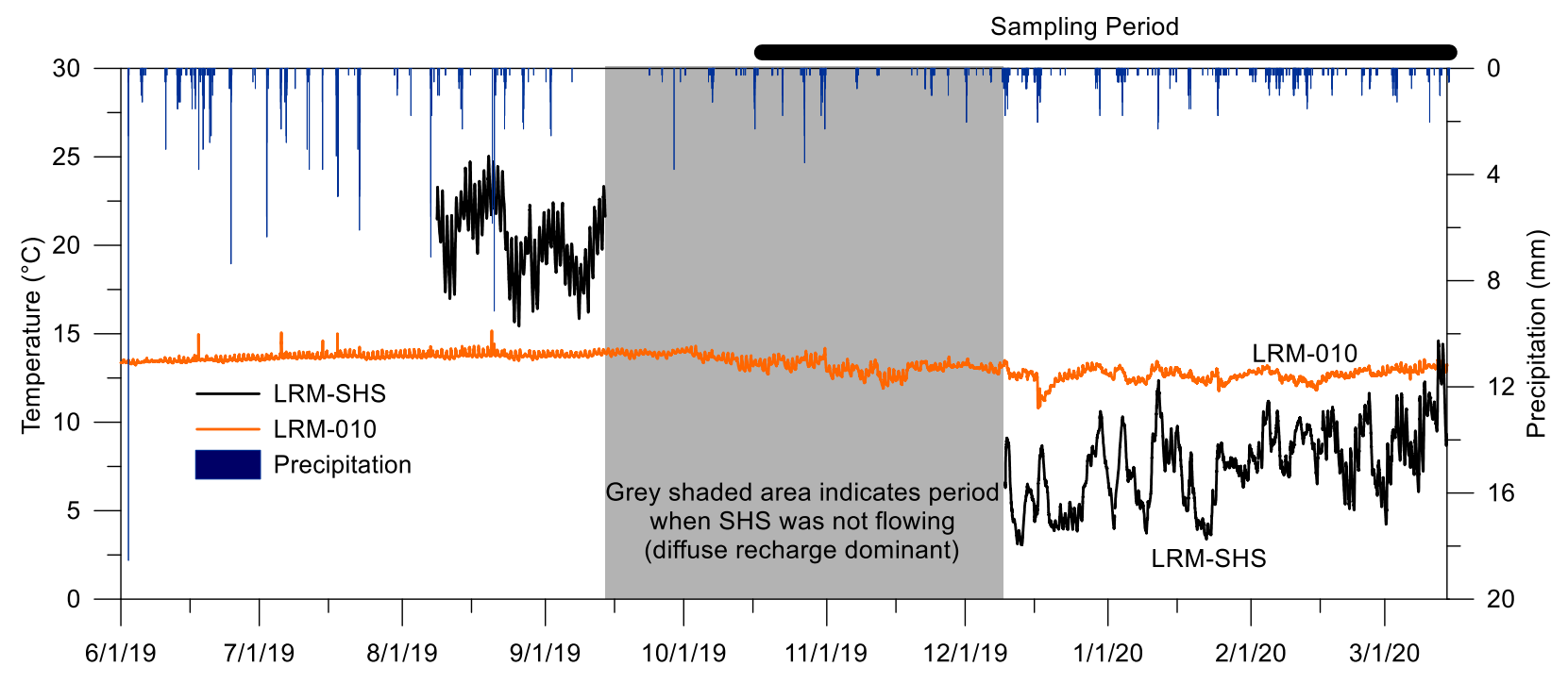

Figure 12: Temperature data from data loggers at LRM-010 and LRM-SHS. 
the LRM-010 temperature record, such as increased flow rate through the mine, "short circuiting" of flowpaths, such as fracture or conduit-dominated flow (Figure 3), and some minor temperature change from direct rainfall into the outflow stream.

\section{Continuous SC}

Continuous SC data ranged between 674 and 1,210 $\mu$ S/cm at LRM-010. LRM-SHS had a wider range of values, from 237 to $1,100 \mu \mathrm{S} / \mathrm{cm}$. From 9/14/2019 to 12/9/2019, LRM-SHS stopped flowing due to dry conditions. The lack of flow was documented by field observations and conductivity values near zero at LRM-SHS. When LRM-SHS was not flowing, diffuse recharge was dominant (Figure 3). Samples collected during this period were classified as diffuse recharge dominated samples, whereas samples collected when LRM-SHS was flowing were classified at direct recharge dominated samples (Table 5). It is unknown whether any direct recharge features other than LRM-SHS enter the mine. Dominant recharge type observations are specific to LRM-SHS only.

$\mathrm{SC}$ decreases indicate a decrease in total dissolved species. Decreases in SC can occur from several processes, including dilution, removal of ions, or changing water sources. SC at LRMSHS decreases immediately following precipitation events. Some rapid SC increases at LRMSHS are also present.

SC decreases similar to LRM-SHS are also observed at LRM-010, although with a lower magnitude (Figure 13). SC decreases at LRM-010 are more prevalent when LRM-SHS was flowing. When LRM-SHS was not flowing, rainfall events were small-magnitude, with little influence on SC at LRM-010 (Figure 13). LRM-010 SC has occasional high SC anomalies, most of which occur immediately after logger offloads (Figure 13).

SC trends at LRM-010 before and after LRM-SHS stopped flowing are noticeably different, with a general decrease and more obvious SC decreases associated with precipitation once LRM-SHS resumes flow (Figure 13). It is unknown whether a baseline SC decrease is normal following the transition from diffuse to direct recharge dominated regimes, or whether this hysteresis is due only to the prolonged precipitation deficit from May to September 2019. It appears SC returns to values observed prior to LRM-SHS dried up near the end of the study period (Figure 13). 
Table 5: Dominant recharge for each sampling date.

\begin{tabular}{|c|c|c|}
\hline Date & $\begin{array}{c}\text { Direct } \\
\text { Recharge } \\
\text { Dominated } \\
\text { (SHS Flowing) }\end{array}$ & $\begin{array}{c}\text { Diffuse } \\
\text { Recharge } \\
\text { Dominated } \\
\text { (SHS Not } \\
\text { Flowing) } \\
\end{array}$ \\
\hline 10/18/2019 & & $\mathrm{X}$ \\
\hline $11 / 2 / 2019$ & & $X$ \\
\hline $11 / 18 / 2019$ & & $X$ \\
\hline $12 / 3 / 2019$ & & $X$ \\
\hline $12 / 18 / 2019$ & $X$ & \\
\hline $1 / 2 / 2020$ & $X$ & \\
\hline $1 / 19 / 2020$ & $X$ & \\
\hline $2 / 2 / 2020$ & $X$ & \\
\hline $2 / 16 / 2020$ & $X$ & \\
\hline $2 / 29 / 2020$ & $X$ & \\
\hline $3 / 14 / 2020^{*}$ & $X$ & \\
\hline
\end{tabular}




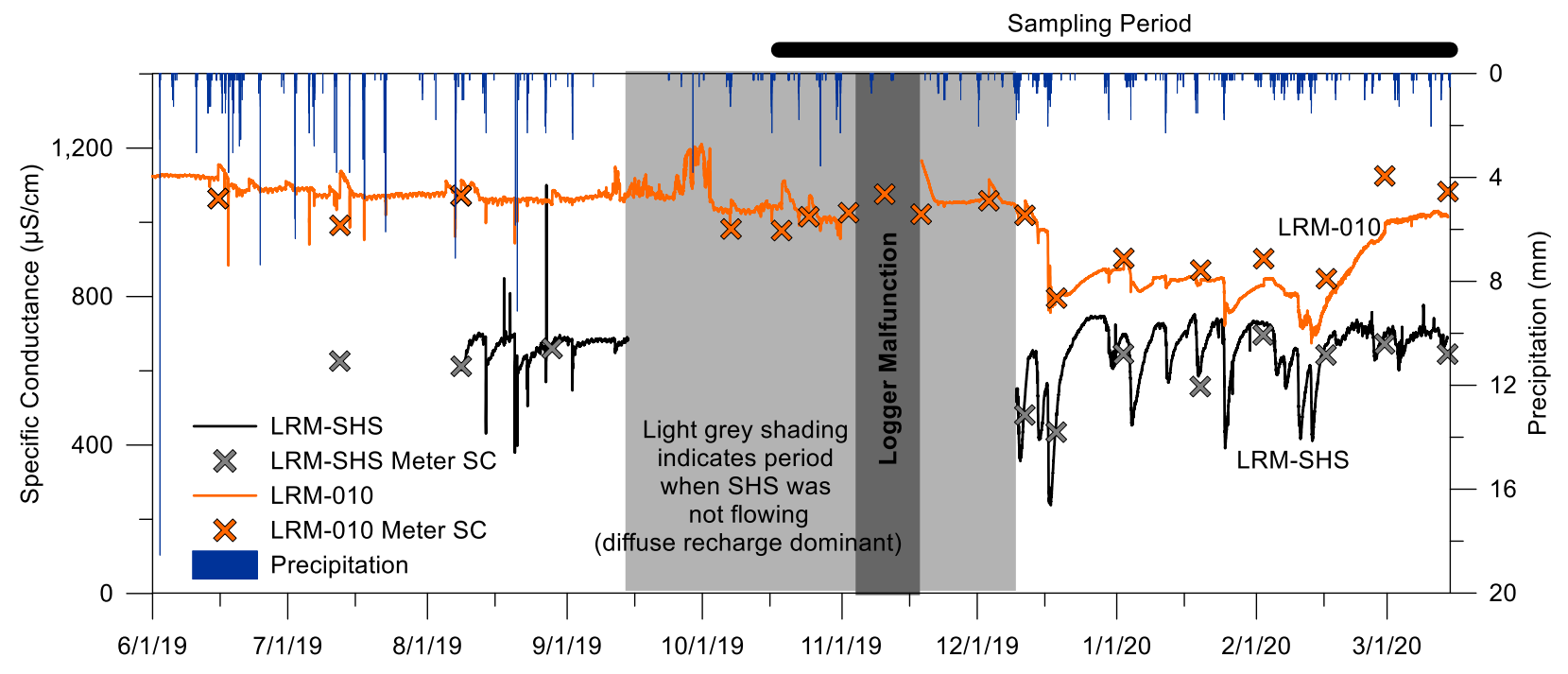

Figure 13: Continuous SC data at LRM-O10 and LRM-SHS. 


\subsubsection{Field Parameters and Discharge}

\section{Data Ranges}

During each sampling event, field parameters were measured at each sampling location. Variability from location to location (i.e. spatial variability) indicates changes along the system flowpath. Temporal variability indicates seasonal or recharge-related changes, both at individual sampling locations and the entire flowpath (Figure 14). Discharge was measured at LRM-010 during each sampling event. During the study period, discharge ranged from $1.31 \times 10^{-3} \mathrm{~m}^{3} / \mathrm{sec}$ to $9.80 \times 10^{-3} \mathrm{~m}^{3} / \mathrm{sec}\left(\right.$ mean $\left.=3.45 \times 10^{-3} \mathrm{~m}^{3} / \mathrm{sec}, \mathrm{n}=14\right)$. The complete dataset is available in Appendix A.

\section{$\underline{\text { Spatial Trends }}$}

Along the treatment system flowpath, $\mathrm{pH}$ and DO increase an average of $62 \%$ and $2,420 \%$, respectively $(\mathrm{n}=14)$ (Figure 14). Atmospheric interaction and aeration cascades along the flowpath increase $\mathrm{DO}$, whereas dissolution of limestone and $\mathrm{CO}_{2}$ degassing raise the $\mathrm{pH}$ along the flowpath. Temperature variability along the flowpath is caused by discharged water responding to atmospheric temperatures (Figure 14). SC along the treatment system flowpath remains relatively constant, with an average decrease of $5.5 \%(n=14)$ (Figure 14), though the ions contributing to SC vary along the flowpath. The spatial trends described above are present during both diffuse and direct recharge regimes (Figure 15).

\section{$\underline{\text { Temporal Trends }}$}

Temporal variability at LRM-000 reflects geochemical changes taking place in the mine workings resulting from recharge. For the purpose of this study, baseline data refers to samples collected while diffuse recharge was dominant.

At LRM-000, $\mathrm{pH}$ variability has a positive linear correlation with discharge during all conditions (Table 6, Figure 16). Discharge increases as direct recharge becomes dominant. As more direct recharge enters the mine, $\mathrm{pH}$ increases from an average baseline value of $\sim 4.0$ to a study period maximum of 5.49. As larger volumes and rates of oxygenated, low $\mathrm{SC}$, higher $\mathrm{pH}$ recharge enters the mine, the geochemical signature of the outflow is changed. LRM-SHS is an example of oxygenated, higher $\mathrm{pH}$ direct recharge rapidly entering the mine (Figure 14 and Figure 15). Samples from LRM-SHS average a pH of $7.90(n=15)$ and $98 \%$ DO saturation $(n=11)$. LRMSHS serves as a recharge water endmember for the site.

SC does not have a clear relationship to discharge at LRM-000 (Table 6). Immediately after LRM-SHS resumes flow (12/9/2019) SC decreases as discharge increases, but the SC decrease does not continue throughout the sampling period (Figure 16). Several factors could explain these discrepancies, including mobilized Fe precipitate in the channel and the presence of additional discharge points between LRM-000 and LRM-010. It is likely that ions contributing to SC change depending on the dominant recharge type, with $\mathrm{Fe}, \mathrm{Al}$, and $\mathrm{Mn}$ being more concentrated during diffuse recharge periods, and $\mathrm{Ca}$ and $\mathrm{Mg}$ being more dominant during direct recharge periods. 
(A)

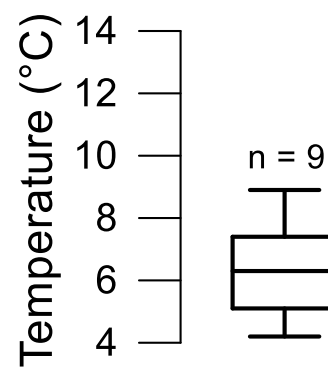

(B)
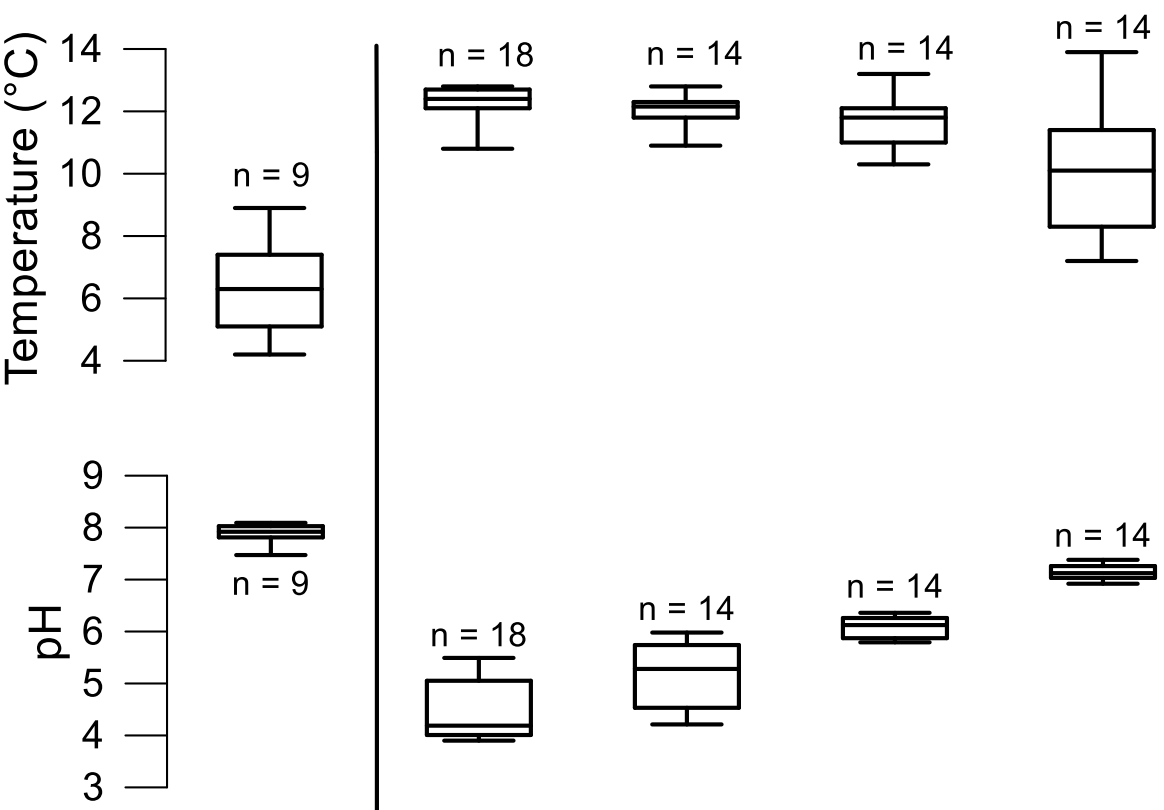

(C)
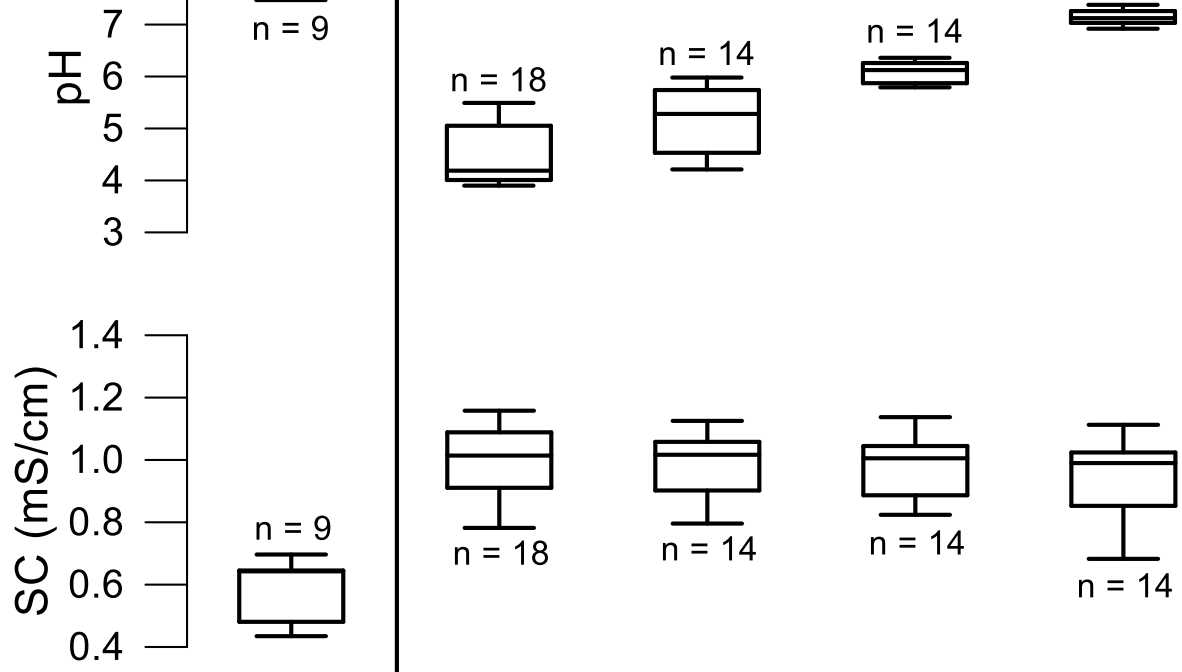

$$
\mathrm{n}=14
$$

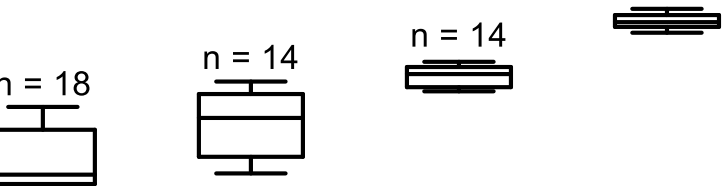

(D)

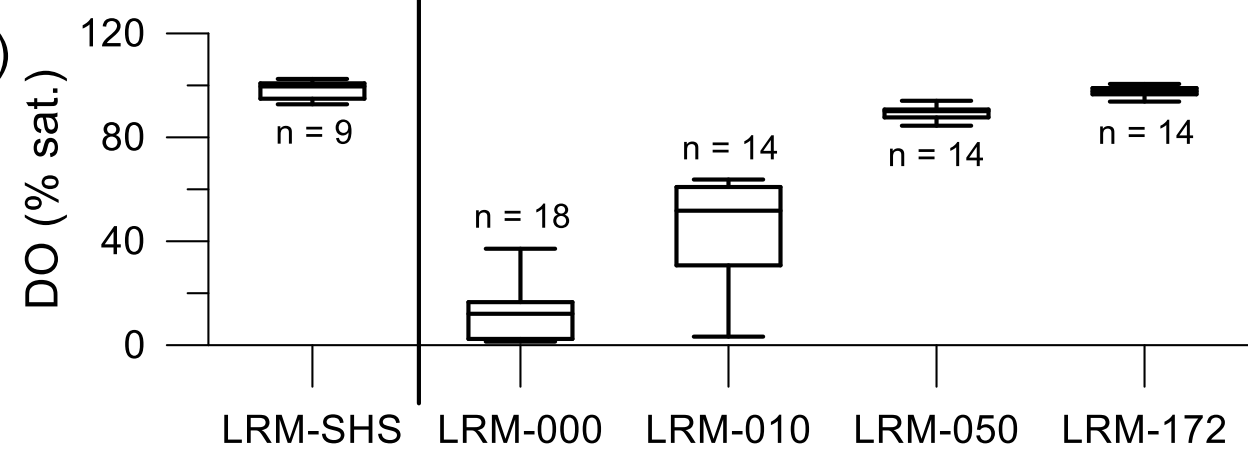

Figure 14: Ranges of measured (A) water temperature, $(B) \mathrm{pH},(C)$ specific conductance, and $(D)$ dissolved oxygen saturation at each sampling location. Whiskers represent maximum and minimum values. 
(A)
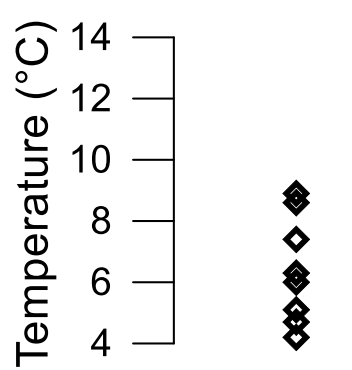

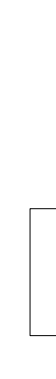

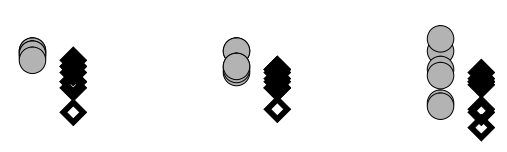

$\checkmark \quad$ Direct Recharge Dominant Diffuse Recharge Dominant

(B)

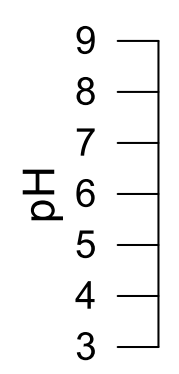

○
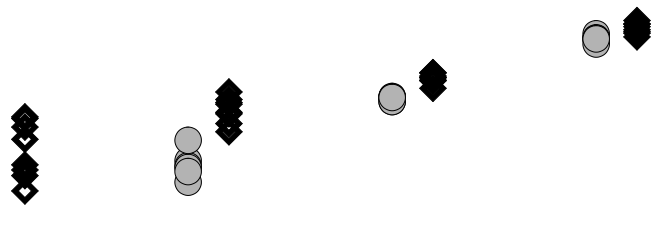

(C)

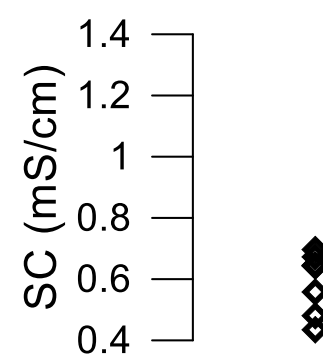

(D)

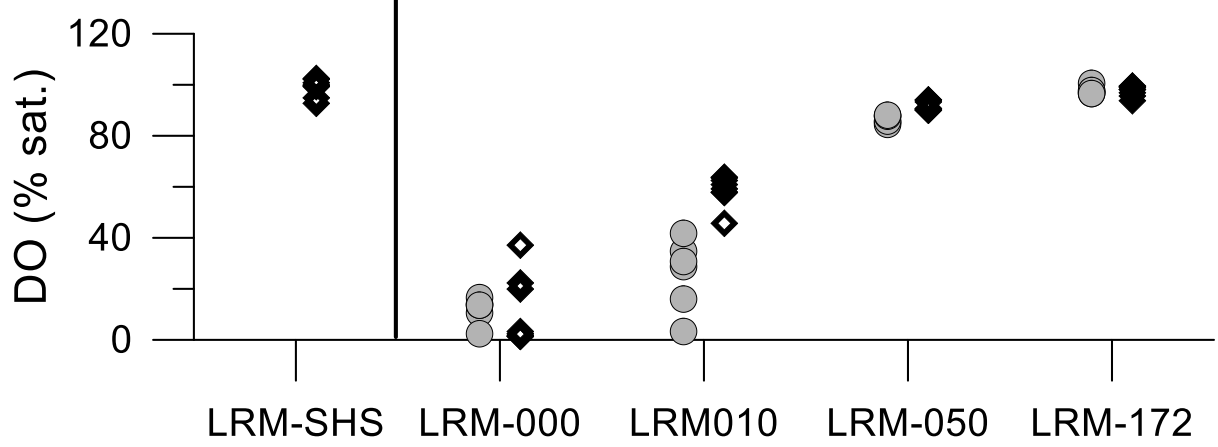

Figure 15: Variability of (A) water temperature, $(B) \mathrm{pH},(C)$ specific conductance, and $(D)$ dissolved oxygen saturation at each sampling location relative to the dominant recharge type. 
Table 6: LRM-000 field parameter correlations to discharge.

\begin{tabular}{lc|c|cc}
\hline Parameter & & $\begin{array}{c}\text { All } \\
\text { Samples }\end{array}$ & $\begin{array}{c}\text { Diffuse } \\
\text { Recharge } \\
\text { Dominated } \\
\mathbf{n = 8}\end{array}$ & $\begin{array}{c}\text { Direct } \\
\text { Recharge } \\
\text { Dominated } \\
\mathbf{n = 1 0}\end{array}$ \\
\hline \multirow{2}{*}{ Temperature } & $\mathrm{R}$ & -0.258 & $\mathbf{0 . 8 1 4}$ & 0.316 \\
& $\mathrm{p}$ & 0.301 & $\mathbf{0 . 0 1 4}$ & 0.374 \\
\hline \multirow{2}{*}{$\mathrm{pH}$} & $\mathrm{R}$ & $\mathbf{0 . 8 9 1}$ & 0.305 & $\mathbf{0 . 8 4 2}$ \\
& $\mathrm{p}$ & $\mathbf{0 . 0 0 0}$ & 0.463 & $\mathbf{0 . 0 0 2}$ \\
\hline \multirow{2}{*}{$\mathrm{SC}$} & $\mathrm{R}$ & 0.236 & -0.532 & $\mathbf{0 . 6 6 9}$ \\
& $\mathrm{p}$ & 0.345 & 0.174 & $\mathbf{0 . 0 3 4}$ \\
\multirow{2}{*}{$\mathrm{DO}(\mathrm{mg} / \mathrm{L})$} & $\mathrm{R}$ & 0.300 & -0.517 & 0.442 \\
& $\mathrm{p}$ & 0.226 & 0.190 & 0.201 \\
\hline
\end{tabular}

Shaded and bolded values indicate $p<0.05$. Pearson correlation values and $p$ values calculated using MINITAB 18 statistical software. 


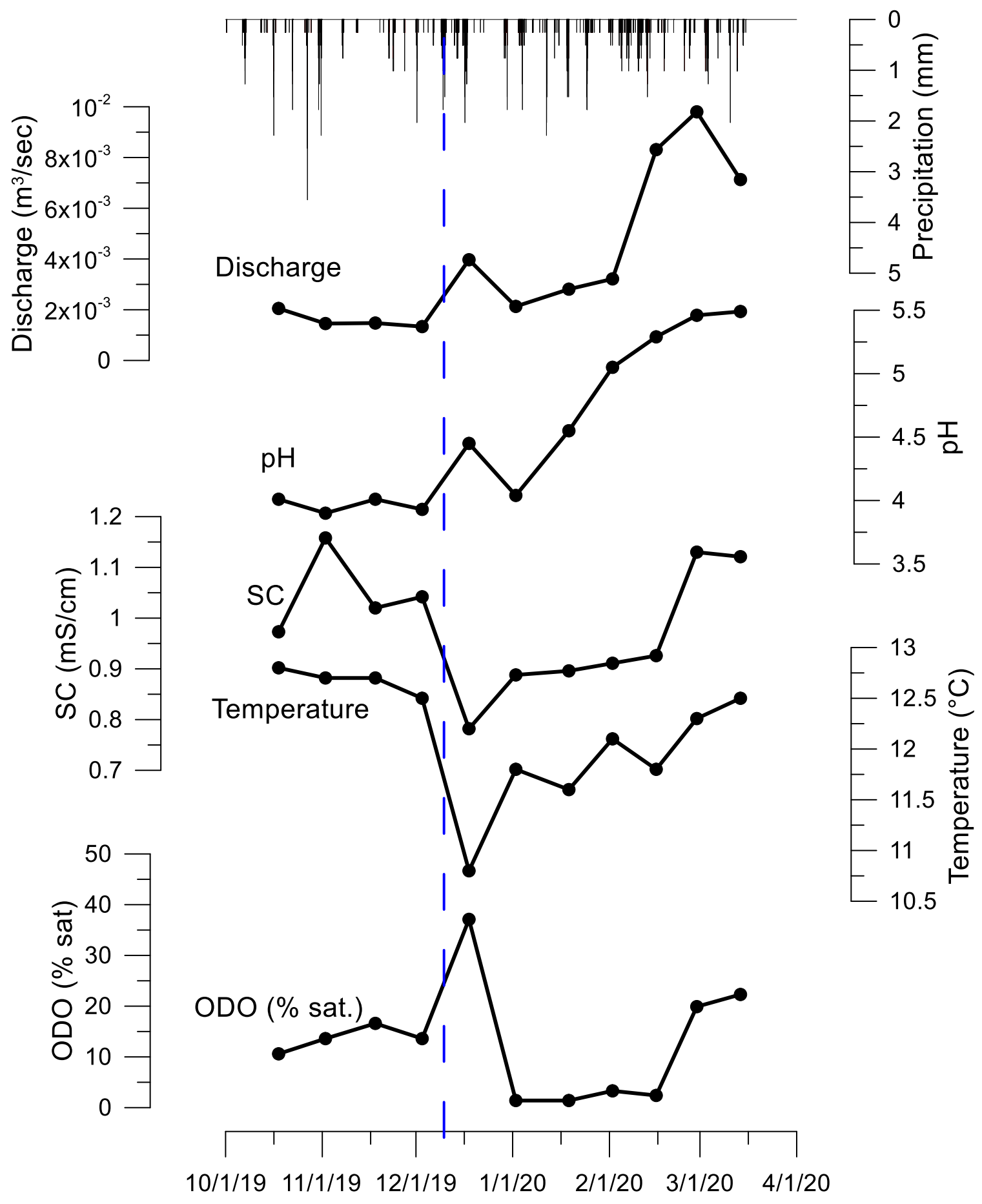

Figure 16: Temporal variability of field parameters at LRM-000 and their relation to discharge. Dashed line indicates division between diffuse recharge dominated (left) and direct recharge dominated (right) periods. 


\subsection{CMD Constituents}

\section{Concentration Ranges}

During each sampling event, filtered samples from each location were collected for ICP-MS and IC analysis (Table 3 and Table 4). Common CMD constituents include Fe, $\mathrm{Al}, \mathrm{Mn}$, and $\mathrm{SO}_{4}$. Samples collected throughout the flowpath provide insight into metal removal, whereas concentration differences at LRM-000 relate to geochemical changes in the mine workings (Figure 17).

\section{Spatial Trends}

The passive treatment system at LRM is designed to remove metals such as $\mathrm{Fe}, \mathrm{Mn}$, and $\mathrm{Al}$ before discharging to Lambert Run (Guardians of the West Fork Watershed, 2003). During both diffuse and direct recharge dominated periods, $\mathrm{Fe}, \mathrm{Mn}$, and $\mathrm{Al}$ concentrations are reduced along the flowpath (Figure 17, Figure 18, Table 7). Concentrations at LRM-000 are highly variable, depending on the dominant type of recharge (Figure 19). $\mathrm{SO}_{4}$ is conservative along the treatment system flowpath (Figure 17, Figure 18, Table 7).

Table 7: Average CMD constituent removal between LRM-000 and LRM-172. When duplicate samples were collected at LRM-000, the non-duplicate sample was used for calculation.

\begin{tabular}{|c|c|c|}
\hline Parameter & $\mathbf{n}$ & $\begin{array}{r}\text { Average \% } \\
\text { removal }\end{array}$ \\
\hline $\mathrm{Fe}^{*}$ & 10 & 78.8 \\
\hline $\mathrm{Al}$ & 10 & 98.8 \\
\hline Mn & 10 & 77.5 \\
\hline $\mathrm{SO}_{4}$ & 10 & 6.3 \\
\hline \multicolumn{3}{|c|}{$\begin{array}{l}\text { *LRM-O00 sample collected on } 2 / 16 / 2020 \\
\text { had a Fe concentration equal to LRM- } \\
172 \text { on that sample date. The 0\% removal } \\
\text { on that date skewed the average \% } \\
\text { removal lower. When not included, Fe } \\
\text { had an average \% removal of } 87.5 \% \text {. }\end{array}$} \\
\hline
\end{tabular}

\section{Temporal Trends}

Concentrations of $\mathrm{Fe}, \mathrm{Mn}, \mathrm{Al}$, and $\mathrm{SO}_{4}$ are relatively constant while diffuse recharge is dominant, (Figure 19, Table 8) compared to concentrations measured while direct recharge was dominant. Following the transition to direct recharge dominated, concentrations of each parameter vary (Table 9). Fe and $\mathrm{Al}$ decrease consistently as direct recharge becomes dominant (Figure 19). During this period, $\mathrm{pH}$ increase from $~ 4.0$ to 5.49 , near the minimum solubility of $\mathrm{Al}(\mathrm{OH})_{3}$ (Figure 20). Across this $\mathrm{pH}$ range, $\mathrm{Fe}(\mathrm{OH})_{2}, \mathrm{Fe}(\mathrm{OH})_{3}$, and $\mathrm{Mn}(\mathrm{OH})_{2}$ solubility also decreases (Figure 20). Though these mineral forms are not the only forms likely precipitated at LRM, they do provide insight to the general trends of metal solubility at varying $\mathrm{pH}$ conditions. 
(A)

(A) 16,000
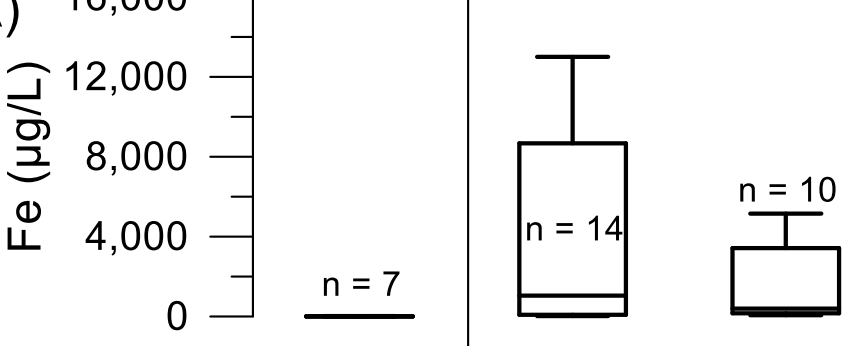

$\mathrm{n}=10$

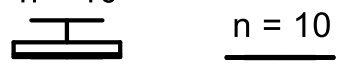

(B)
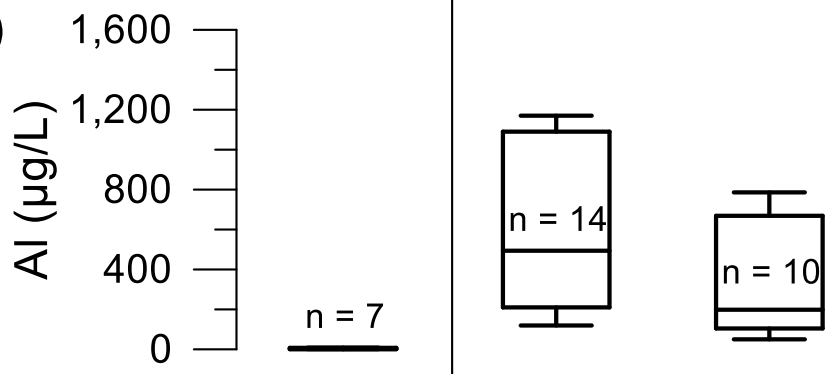

$\mathrm{n}=10$

$n=10$

(C)

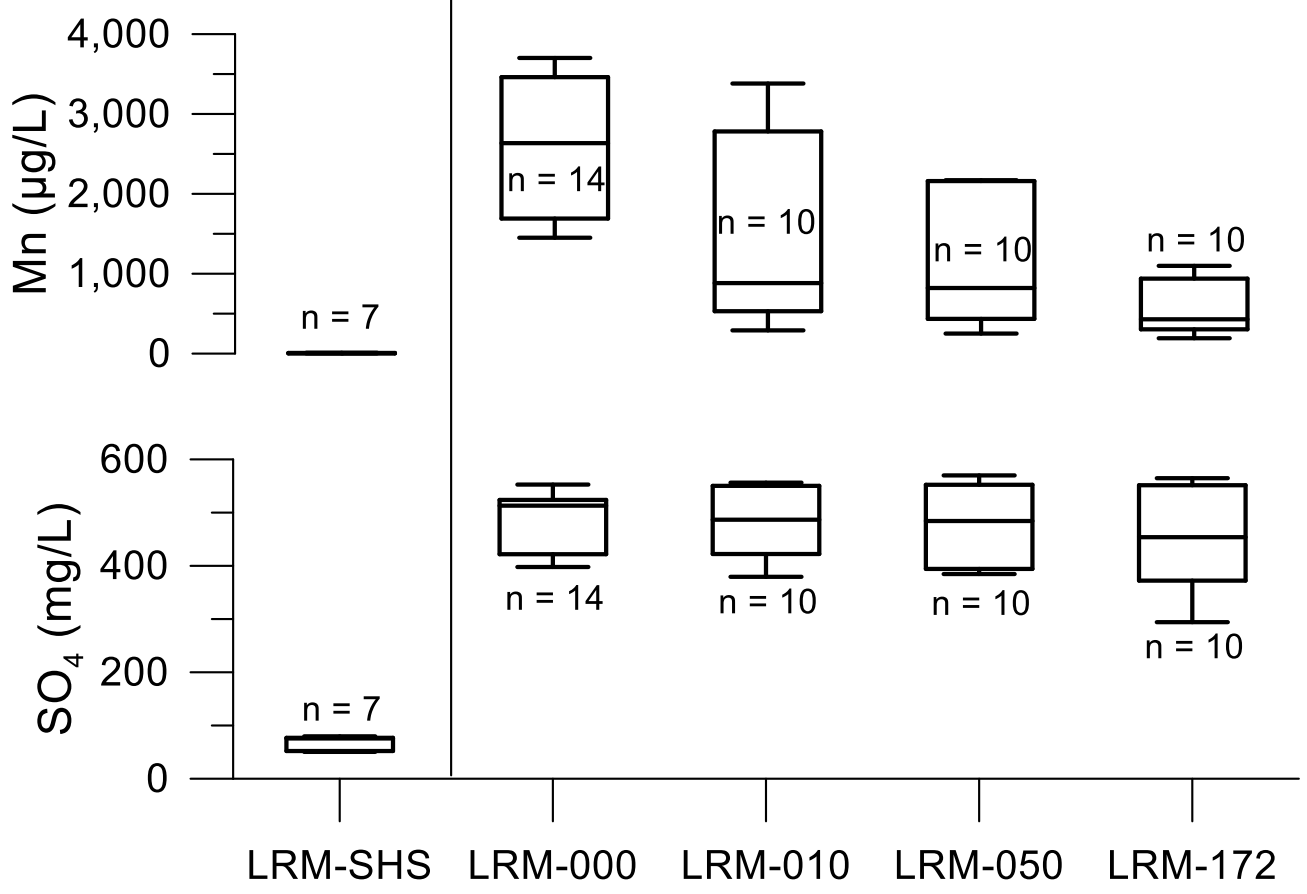

Figure 17: Concentration ranges of $(A) F e,(B), A l,(C), M n$, and $(D)$ SO4 at each sampling location. Whiskers represent maximum and minimum values. 
(A)

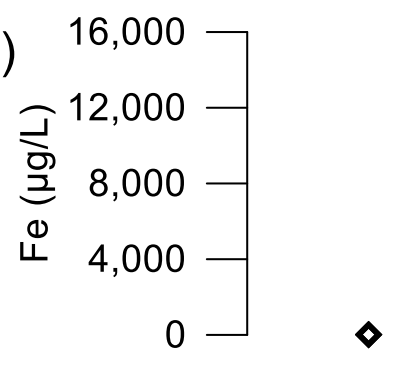

(B)

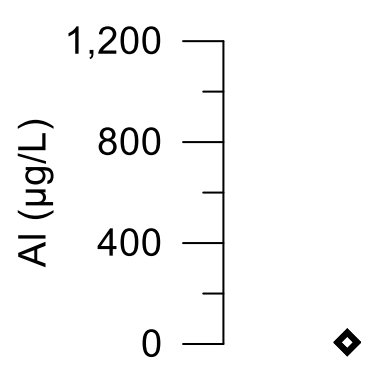

(C)

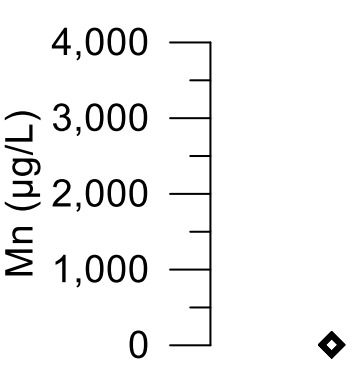

(D)

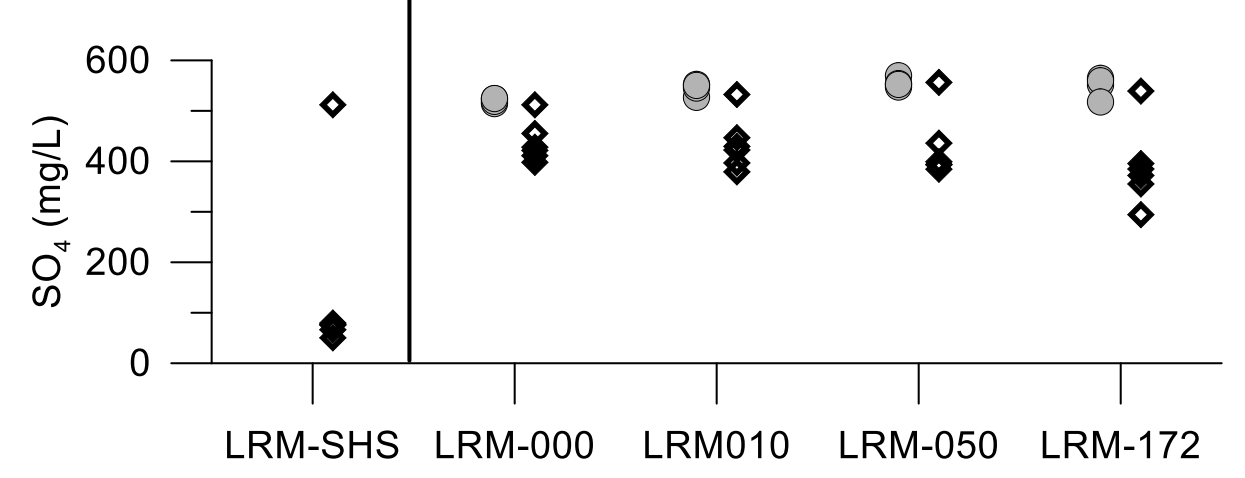

Figure 18: Variability of $(A) F e,(B) A l,(C) M n$, and (D) SO4 at each sampling location relative to the dominant recharge type. 
Table 8: Diffuse recharge dominated sample concentration ranges at LRM-000.

\begin{tabular}{lcccc}
\hline Parameter & n & Maximum & Minimum & \% Difference \\
\hline $\mathrm{Fe}(\mathrm{mg} / \mathrm{L})$ & 6 & 13.0 & 7.8 & 40.3 \\
$\mathrm{Al}(\mathrm{mg} / \mathrm{L})$ & 6 & 1.17 & 0.99 & 15.1 \\
$\mathrm{Mn}(\mathrm{mg} / \mathrm{L})$ & 6 & 3.70 & 2.75 & 25.7 \\
$\mathrm{SO}_{4}(\mathrm{mg} / \mathrm{L})$ & 6 & 553 & 514 & 7.0 \\
\hline$\%$ difference calculated between maximum and minimum concentrations.
\end{tabular}

Table 9: Average CMD constituent concentrations at LRM-000.

\begin{tabular}{lrr}
\hline Parameter & $\begin{array}{r}\text { Diffuse Recharge } \\
\text { Dominated } \\
\mathbf{n = 6}\end{array}$ & $\begin{array}{r}\text { Direct Recharge } \\
\text { Dominated } \\
\mathbf{n = 1 1}\end{array}$ \\
\hline $\mathrm{Fe}(\mathrm{mg} / \mathrm{L})$ & 9.75 & 0.27 \\
$\mathrm{Al}(\mathrm{mg} / \mathrm{L})$ & 1.10 & 0.27 \\
$\mathrm{Mn}(\mathrm{mg} / \mathrm{L})$ & 3.41 & 1.94 \\
$\mathrm{SO}_{4}(\mathrm{mg} / \mathrm{L})$ & 525 & 441 \\
\hline
\end{tabular}

Using concentration data and measured discharge, daily loading calculations were performed for each CMD constituent at LRM-000. Loading calculations throughout the sampling period demonstrate that Fe loading decreases from the diffuse to direct recharge dominated periods, with direct recharge loading being roughly one quarter of diffuse recharge loading (Figure 21). Decreased loading is partially due to decreased solubility of Fe hydroxide minerals at higher $\mathrm{pH}$. Al loading generally decreases, though the trend is not as smooth as Fe. This may be because $\mathrm{Al}$ concentrations are lower, so minor deviations in measured concentrations may result in greater error and variability in the loading values when multiplied by discharge.

$\mathrm{Mn}$ and $\mathrm{SO}_{4}$ loading increase during the direct recharge dominated period. $\mathrm{SO}_{4}$ behaves conservatively in most mine drainage settings, unless in the presence of sulfide reducing bacteria (Stumm and Morgan, 1996). Increased volumes of recharge entering the mine are potentially mobilizing $\mathrm{SO}_{4}$ stored in efflorescent mineral crusts (e.g. melanterite, $\left[\mathrm{FeSO}_{4} \bullet 7 \mathrm{H}_{2} \mathrm{O}\right]$ ), hydraulically isolated pools in the mine workings, or from additional/increased oxidation of pyrite.

Throughout the study period, Fe, Al, and Mn at LRM-000 have a significant ( $\mathrm{p}<0.05)$ negative correlation to discharge. $\mathrm{SO}_{4}$ does not have a significant correlation with discharge at LRM-000 (Table 10). Complete correlation matrices are available in Appendix B. 


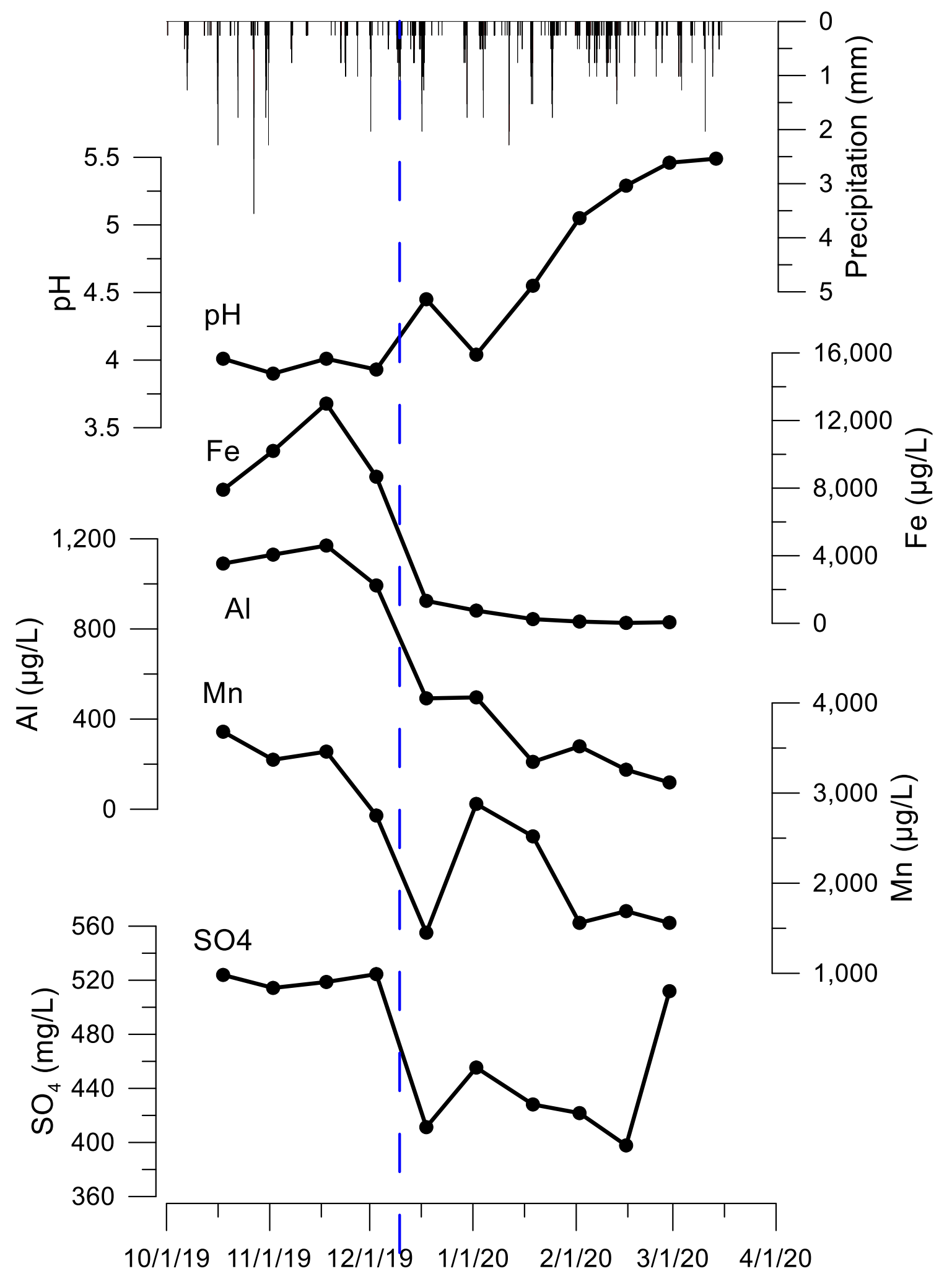

Figure 19: CMD constituent temporal variability at LRM-000. Dashed line indicates division between diffuse recharge dominated (left) and direct recharge dominated (right) periods. 


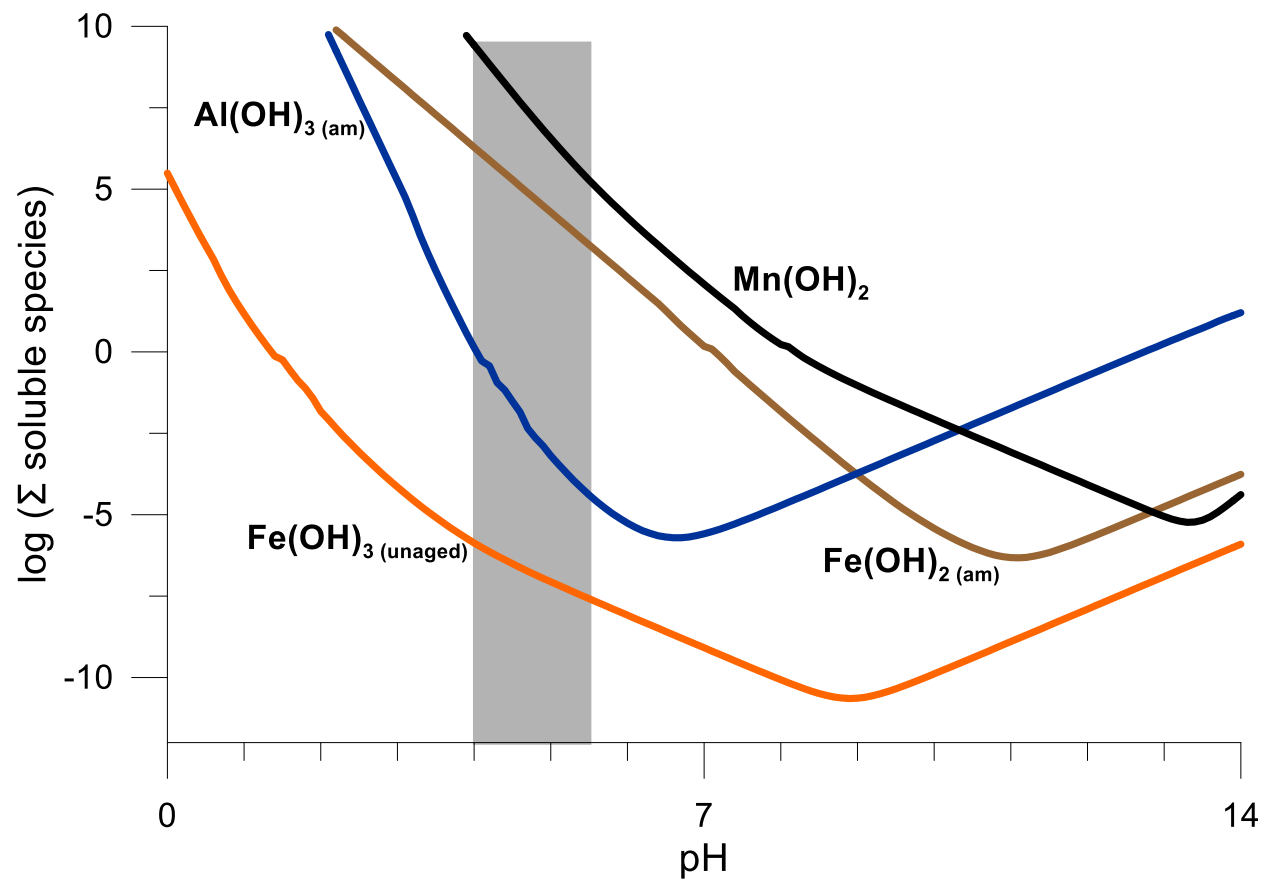

Figure 20: Hydroxide solubility for major CMD cations. Grey bar indicates $p H$ range at LRM-000 during the study period. Solubility lines generated using Visual MINTEQ version 3.1 (Gustaffson, 2018), allowing unlimited supplies of each mineral to dissolve at $13^{\circ} \mathrm{C}$. $\mathrm{Al}(\mathrm{OH})_{3}$ and $\mathrm{Fe}(\mathrm{OH})_{2}$ modeled as amorphous forms. $\mathrm{Fe}(\mathrm{OH})_{3}$ modeled as unaged form. 


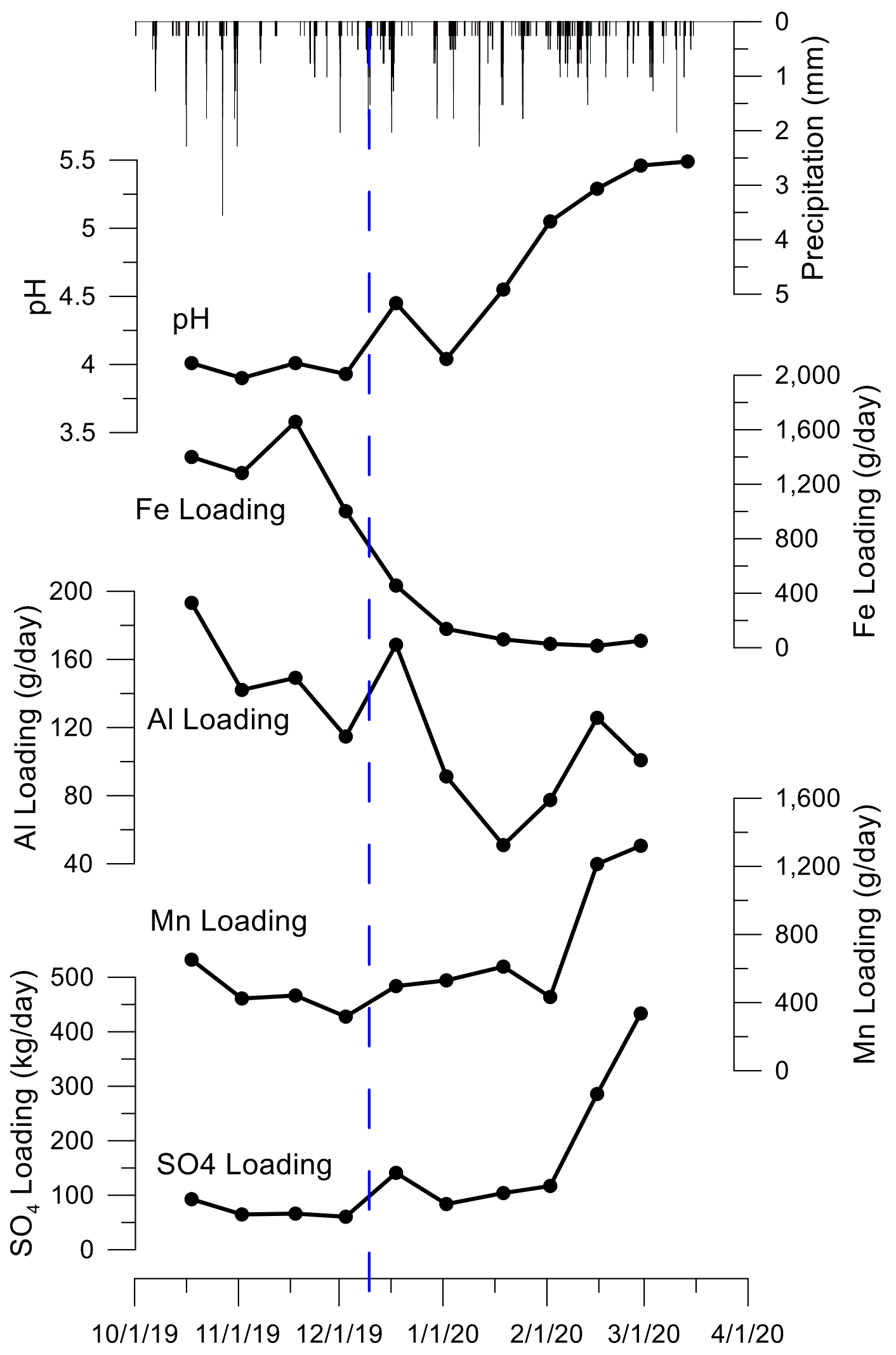

Figure 21: CMD constituent loading variability at LRM-000. Dashed line indicates division between diffuse recharge dominated (left) and direct recharge dominated (right) periods. 
Table 10: LRM-000 CMD constituent correlations to discharge. Duplicate samples were included in correlation analysis.

\begin{tabular}{|c|c|c|c|c|}
\hline \multicolumn{2}{|c|}{ Parameter } & $\begin{array}{c}\text { All } \\
\text { Samples } \\
\text { n=14 }\end{array}$ & $\begin{array}{c}\text { Diffuse } \\
\text { Recharge } \\
\text { Dominated } \\
n=6\end{array}$ & $\begin{array}{c}\text { Direct } \\
\text { Recharge } \\
\text { Dominated } \\
n=8\end{array}$ \\
\hline \multirow{2}{*}{$\mathrm{pH}$} & $\mathrm{R}$ & 0.891 & 0.305 & 0.842 \\
\hline & $\mathrm{p}$ & 0.000 & 0.463 & 0.002 \\
\hline \multirow{2}{*}{$\mathrm{Fe}$} & $\mathrm{R}$ & -0.635 & -0.630 & -0.445 \\
\hline & $\mathrm{p}$ & 0.015 & 0.180 & 0.269 \\
\hline \multirow{2}{*}{$\mathrm{Al}$} & $\mathrm{R}$ & -0.732 & -0.011 & -0.690 \\
\hline & $\mathrm{p}$ & 0.003 & 0.984 & 0.058 \\
\hline \multirow{2}{*}{$\mathrm{Mn}$} & $\mathrm{R}$ & -0.680 & 0.741 & -0.452 \\
\hline & $\mathrm{p}$ & 0.007 & 0.092 & 0.261 \\
\hline \multirow{2}{*}{$\mathrm{SO}_{4}$} & $\mathrm{R}$ & -0.110 & 0.680 & 0.624 \\
\hline & $\mathrm{p}$ & 0.708 & 0.138 & 0.098 \\
\hline
\end{tabular}

\subsection{Yttrium and Rare Earth Elements (YREE)}

Concentration Ranges

During each sampling event, filtered samples were collected for ICP-MS analysis, including analysis for YREE (Table 3 and Table 4). Total YREE concentrations varied in space and time. Concentrations were greatest at LRM-000, then decreased along the treatment system flowpath. LRM-SHS had low YREE concentrations (Figure 22). YREE concentrations at LRM are enriched in MREE compared to the North American Shale Composite (NASC) (Gromet et al., 1984), typical of many Appalachian CMD discharges (Figure 23).

\section{$\underline{\text { Spatial Trends }}$}

Along the flowpath, YREE concentrations decrease. On average, 97\% of YREE were removed between LRM-000 and LRM-172 for all sample sets during the study period $(n=10)$.

After discharging at LRM-000, geochemical processes removing YREE are evident along the flowpath. Normalizing downstream concentrations to LRM-000 concentrations shows preferential removal of certain elements (Figure 24). These removal trends are typical of LRM throughout the study period, with some exceptions.

Along the flowpath, $\mathrm{Ce}$ is preferentially removed in a short flow distance (Figure 24). The rapid, preferential removal of $\mathrm{Ce}$ is possibly due to oxidation of $\mathrm{Ce}^{3+}$ to insoluble $\mathrm{Ce}^{4+}$. Along the flowpath, $\mathrm{Y}$ is removed less than the lanthanide series elements, indicating sorption to oxide minerals is a likely process removing YREE from solution (Bau, 1999; Lawrence et al., 2006; Vesper and Smilley, 2010) 
Some sample dates do not follow the typical pattern of YREE removal present in Figure 24. For example, on 10/18/2019, the concentration of Y along the flowpath is greater than Y at LRM000 (Figure 25). On 11/2/2019, Y at all sample locations was below detection (Figure 26). At present, no distinct cause is evident for the occasional variability YREE removal patterns.

\section{Temporal Trends}

Temporal variations in YREE concentration at LRM-000 provide insight into the geochemistry and hydrogeology of the mine system relative to the dominant recharge type. YREE concentrations at LRM-000 range between 2.29 and $15.08 \mu \mathrm{g} / \mathrm{L}$ throughout the study period (Figure 22). Maximum YREE concentrations at LRM-000 occurred on 11/18/2019 and 12/3/2019, near the end of the diffuse recharge dominated period (Figure 27). All energy critical YREE follow this same pattern, though the concentrations of each element vary.

Total YREE loading at LRM-000 remains relatively constant throughout the sampling period, undulating around the average loading value of $1.58 \mathrm{~g} /$ day total YREE (Figure 28). When YREE concentrations reached their minimum values near the end of the study period, YREE removal also decreased to a minimum of $85 \%$ removal.

In recent years, focus has been paid to YREE association in CMD systems, both in the aqueous form and sorption to minerals in CMD treatment systems (Stewart et al., 2017; Hedin et al., 2019; Wallrich et al., 2020). Throughout the study period, total YREE had significant correlations to $\mathrm{pH}, \mathrm{Fe}, \mathrm{Al}, \mathrm{Mn}, \mathrm{Si}$ and $\mathrm{K}$, regardless of the dominant recharge type (Table 11). Though the parameters with which YREE correlates change when the dominant recharge type is differentiated (Table 11). 


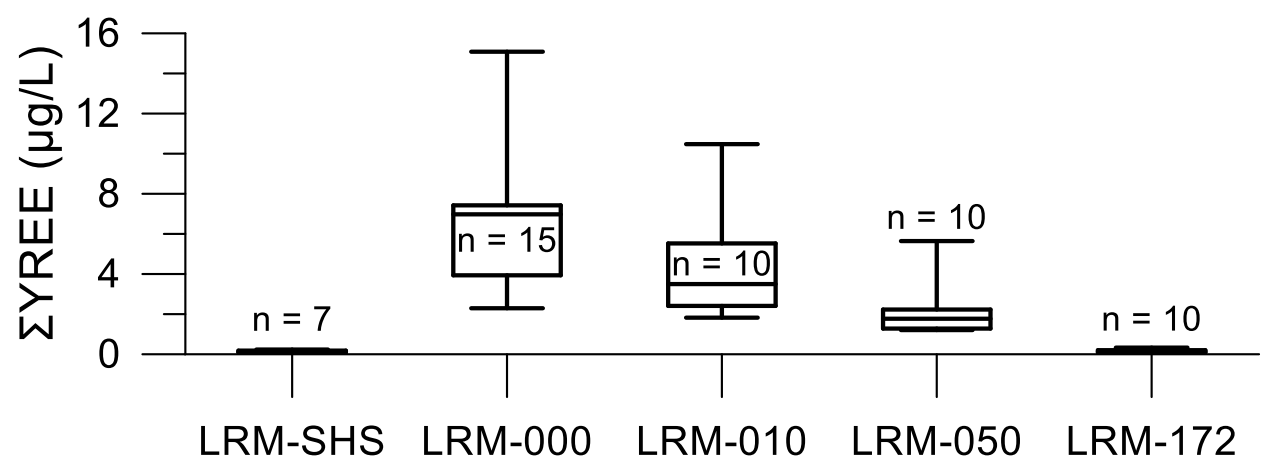

Figure 22: Concentration range of total YREE at each sampling location. Whiskers represent maximum and minimum values. 


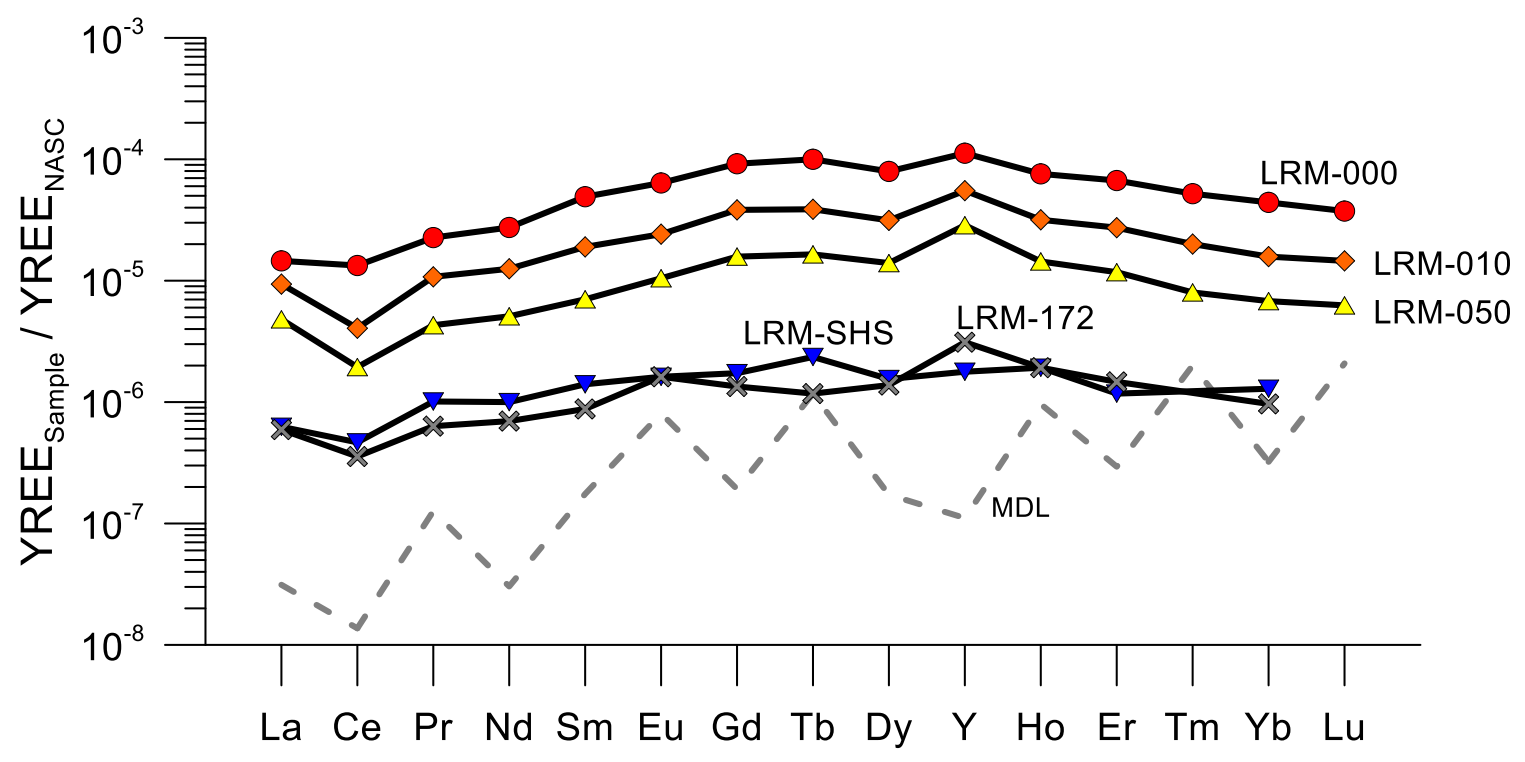

Figure 23: Typical YREE enrichment relative to NASC (Gromet et al., 1984) at LRM. Data from samples collected on 12/18/2019. 


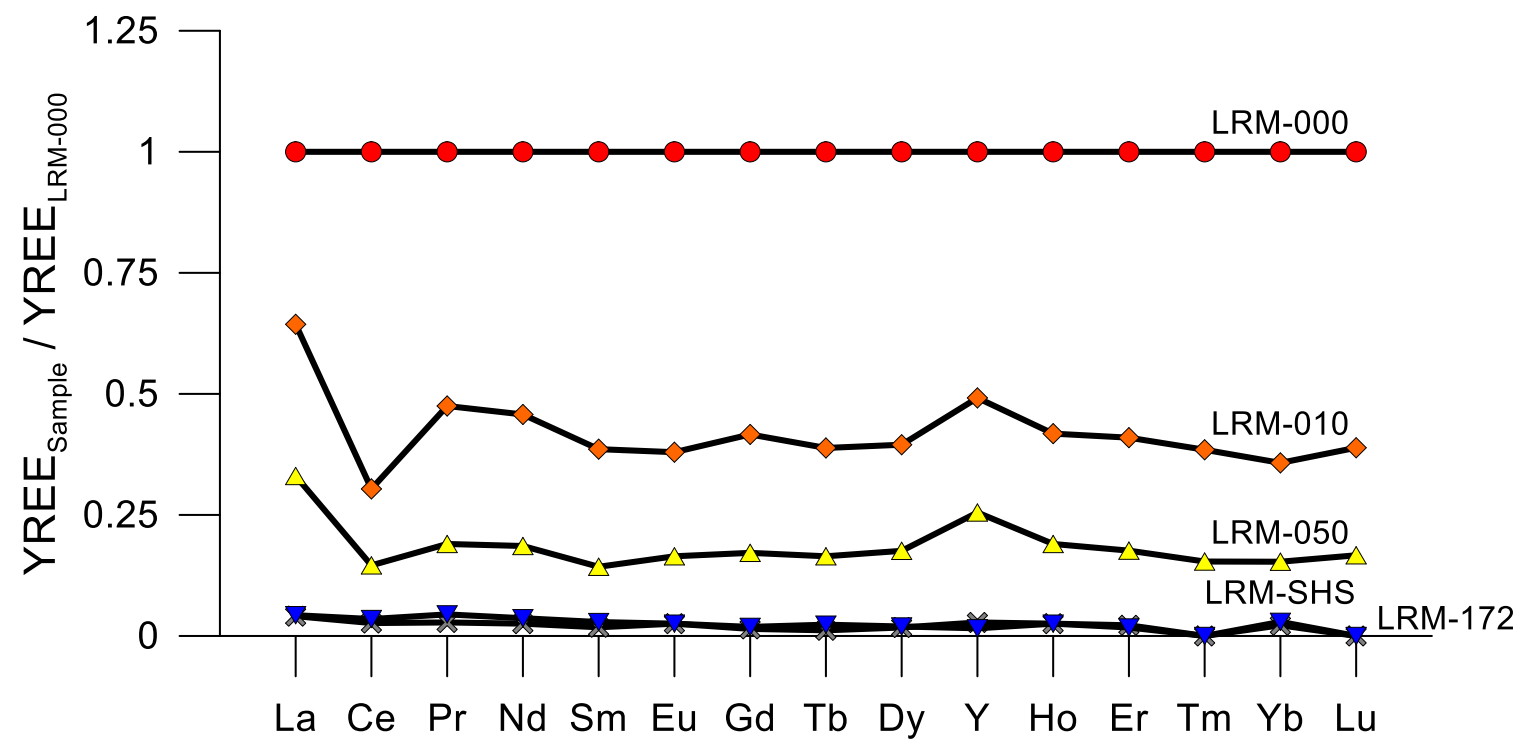

Figure 24: Typical YREE removal along the LRM flowpath. Data from samples collected on 12/18/2019. 


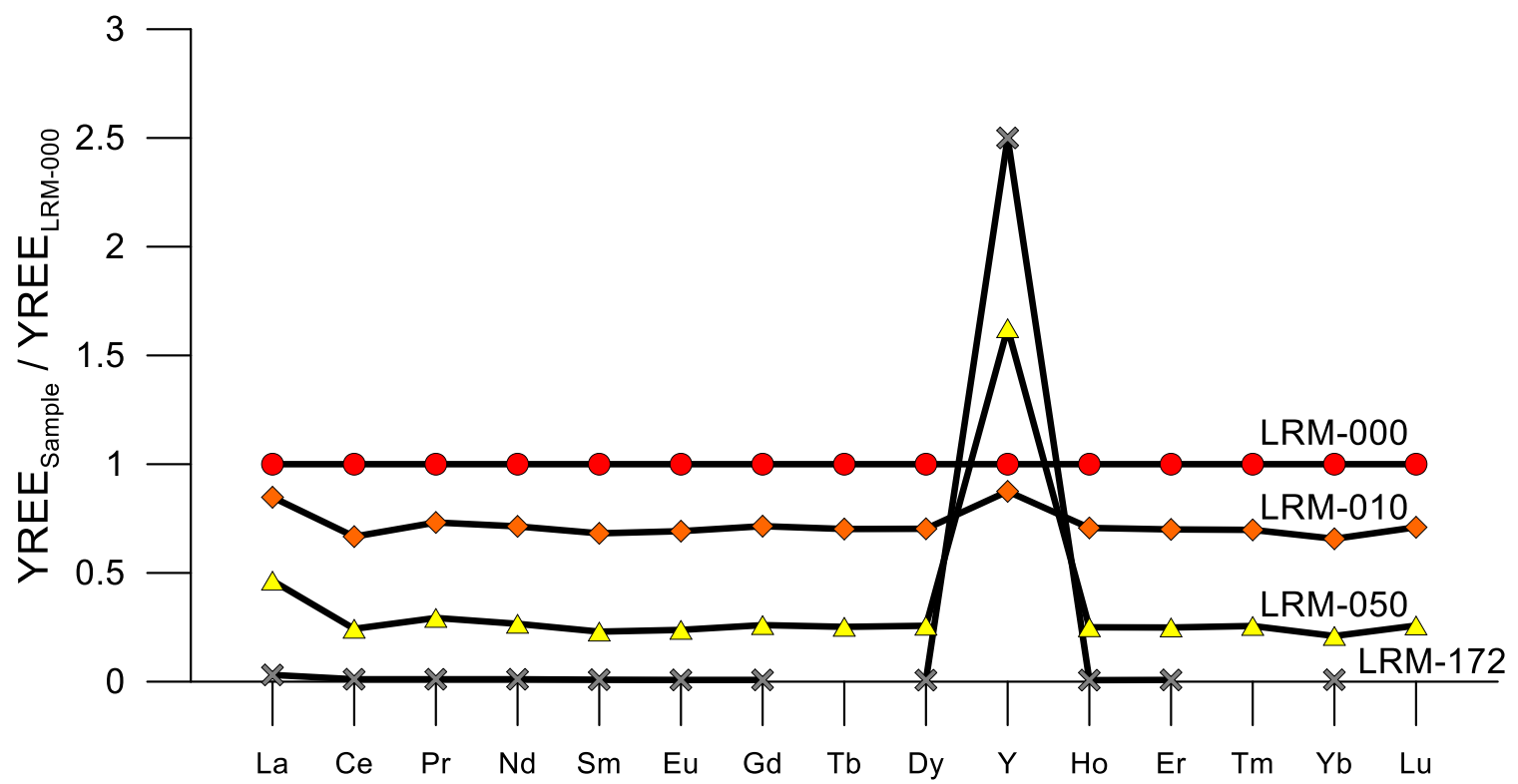

Figure 25: YREE removal anomaly where Y concentration increases along the flowpath. Data from samples collected on 10/18/2019. 


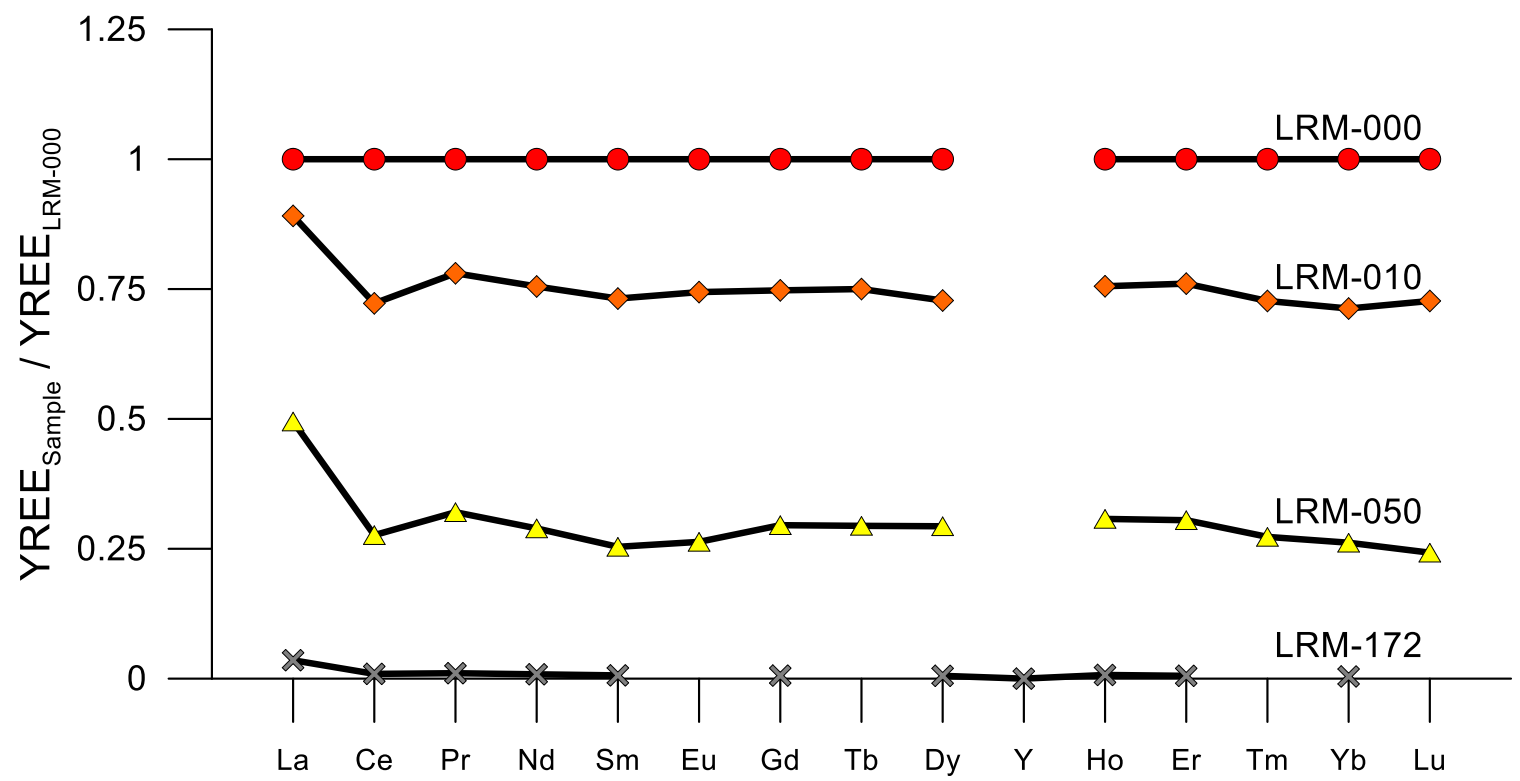

Figure 26: YREE removal anomaly, where $Y$ is not present at detectable concentrations at any sample location. Data from samples collected on 11/2/2019. 


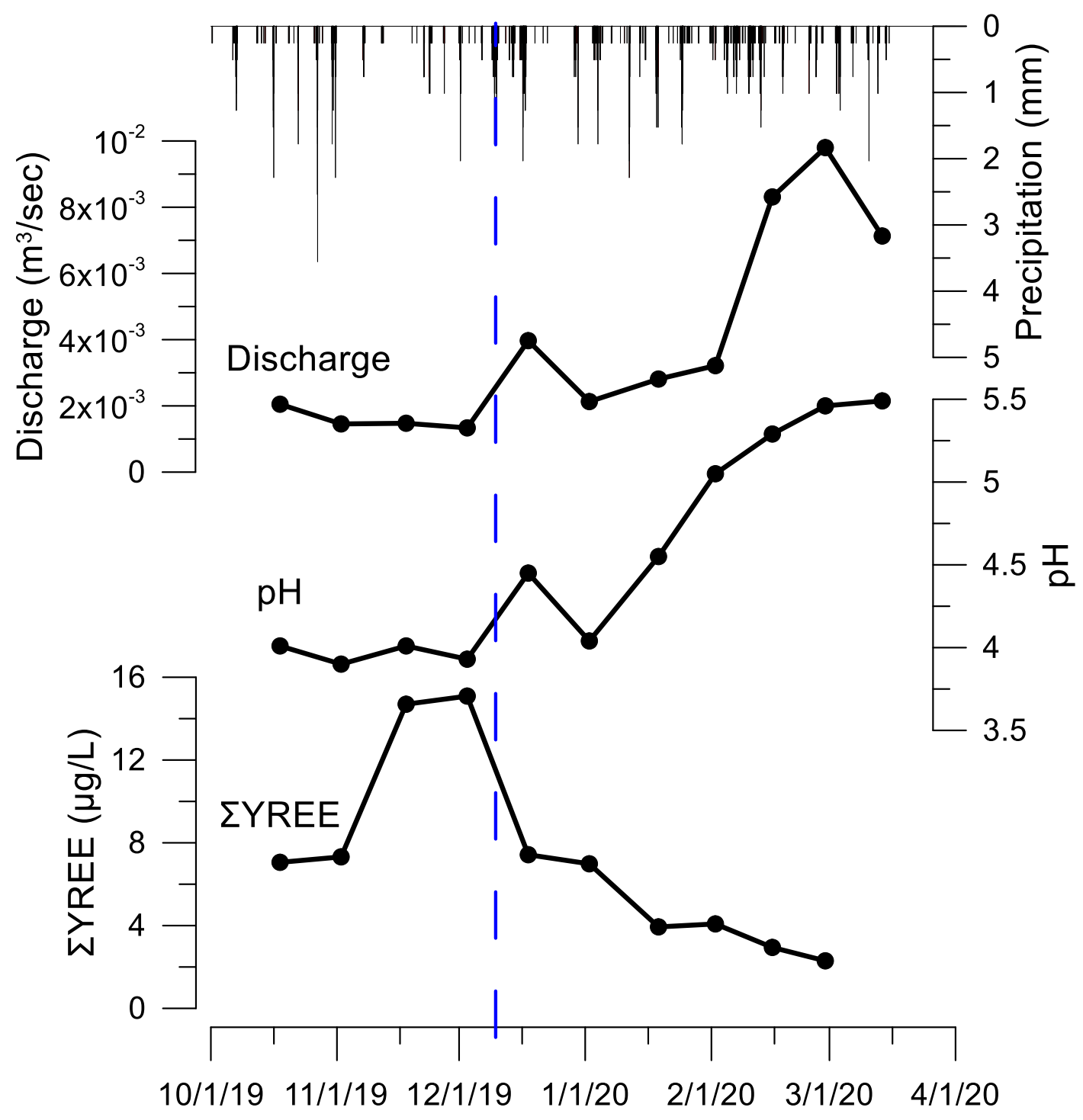

Figure 27: Total YREE concentration temporal variability at LRM-000. Dashed line indicates division between diffuse recharge dominated (left) and direct recharge dominated (right) periods 


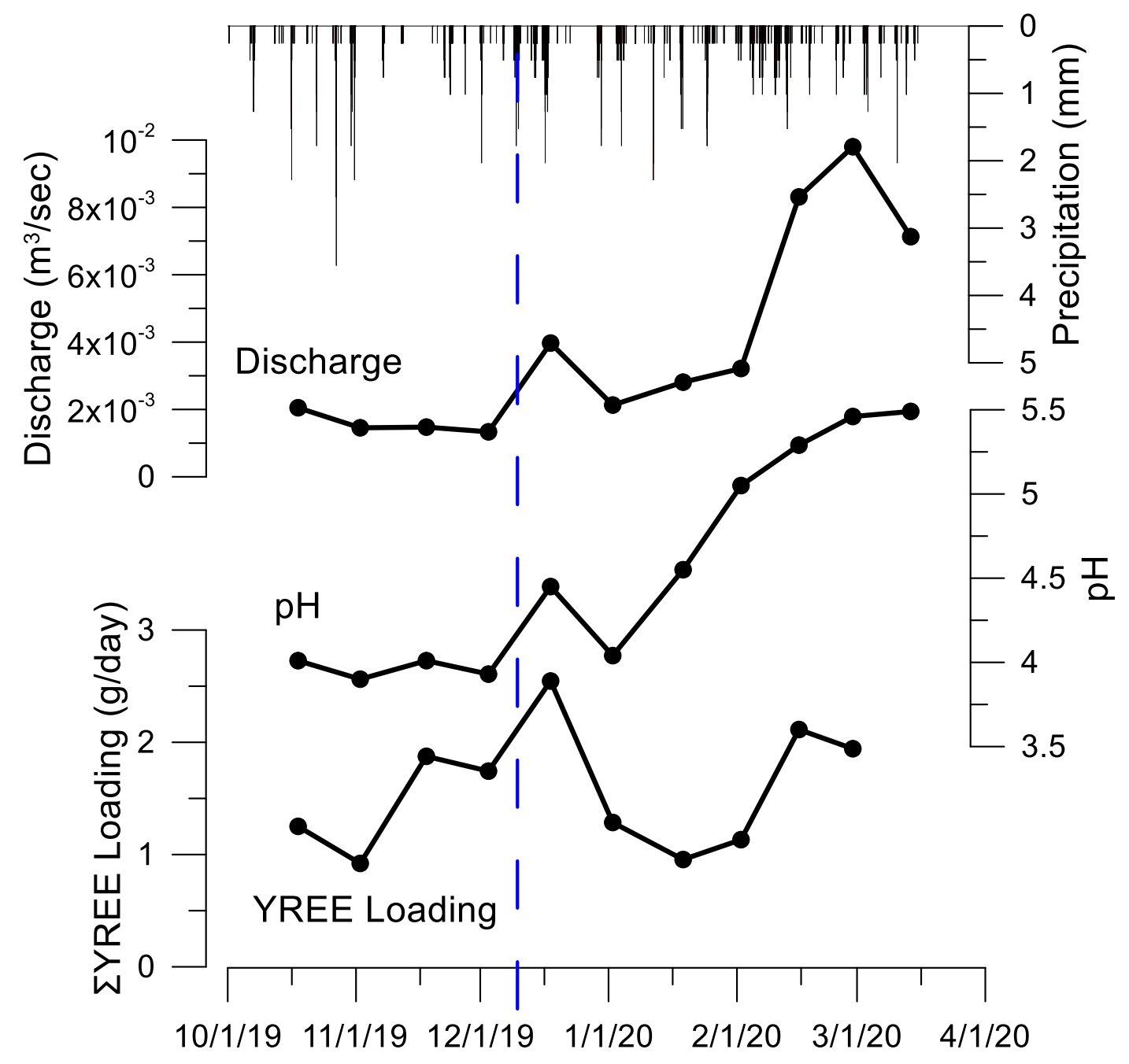

Figure 28: Temporal variability of YREE loading at LRM-000. Dashed line indicates division between diffuse recharge dominated (left) and direct recharge dominated (right) periods. 
Table 11: Correlations to YREE at LRM-000.

\begin{tabular}{|c|c|c|c|c|}
\hline \multicolumn{2}{|l|}{ Parameter } & $\begin{array}{c}\text { All } \\
\text { Samples } \\
n=14\end{array}$ & $\begin{array}{c}\text { Diffuse } \\
\text { Recharge } \\
\text { Dominated } \\
n=6\end{array}$ & $\begin{array}{c}\text { Direct } \\
\text { Recharge } \\
\text { Dominated } \\
n=8\end{array}$ \\
\hline \multirow{2}{*}{ Temperature } & $\mathrm{R}$ & 0.385 & -0.694 & -0.751 \\
\hline & $\mathrm{p}$ & 0.174 & 0.126 & 0.032 \\
\hline \multirow{2}{*}{$\mathrm{pH}$} & $\mathrm{R}$ & -0.759 & 0.074 & -0.886 \\
\hline & $\mathrm{p}$ & 0.002 & 0.889 & 0.003 \\
\hline \multirow{2}{*}{$\mathrm{SC}$} & $\mathrm{R}$ & 0.102 & -0.034 & -0.766 \\
\hline & $\mathrm{p}$ & 0.728 & 0.949 & 0.027 \\
\hline \multirow{2}{*}{$\mathrm{Fe}$} & $\mathrm{R}$ & 0.837 & 0.597 & 0.924 \\
\hline & $\mathrm{p}$ & 0.000 & 0.211 & 0.001 \\
\hline \multirow{2}{*}{$\mathrm{Al}$} & $\mathrm{R}$ & 0.804 & -0.017 & 0.991 \\
\hline & $\mathrm{p}$ & 0.001 & 0.974 & 0.000 \\
\hline \multirow{2}{*}{$\mathrm{Mn}$} & $\mathrm{R}$ & 0.611 & -0.577 & 0.286 \\
\hline & $\mathrm{p}$ & 0.020 & 0.231 & 0.493 \\
\hline \multirow{2}{*}{$\mathrm{Si}$} & $\mathrm{R}$ & 0.518 & -0.981 & 0.293 \\
\hline & $\mathrm{p}$ & 0.058 & 0.001 & 0.482 \\
\hline \multirow{2}{*}{ K } & $\mathrm{R}$ & 0.772 & 0.862 & 0.391 \\
\hline & $\mathrm{p}$ & 0.001 & 0.027 & 0.338 \\
\hline \multirow{2}{*}{ DIC } & $\mathrm{R}$ & -0.043 & -0.845 & -0.805 \\
\hline & $\mathrm{p}$ & 0.883 & 0.034 & 0.016 \\
\hline \multirow{2}{*}{ Discharge } & $\mathrm{R}$ & -0.664 & -0.738 & -0.691 \\
\hline & $\mathrm{p}$ & 0.010 & 0.094 & 0.058 \\
\hline
\end{tabular}

Shaded and bolded values indicate $p<0.05$. Pearson correlation values and $p$ values calculated using MINITAB 18 statistical software. 


\section{6 $\mathrm{CaCO}_{3}$-Water System}

Concentration Ranges

DIC and dissolved $\mathrm{CO}_{2}$ were measured in the field at each sampling location during each field event, whereas dissolved $\mathrm{Ca}$ and $\mathrm{Mg}$ concentrations were obtained from filtered ICP-MS samples. If $\mathrm{pH}$ was less than 5.0, DIC was not measured in the field. When samples had a $\mathrm{pH}$ greater than 5.0, DIC and $\mathrm{CO}_{2}$ were both measured. When DIC and $\mathrm{CO}_{2}$ were both measured, the larger value was used for calculation and analysis. Dissolved $\mathrm{Ca}$ and $\mathrm{Mg}$ is primarily from the dissolution of impure limestone, either from the local stratigraphy or limestone present in the remediated channel (Figure 8).

DIC concentrations at LRM are variable throughout the flow system and variable in time (Figure 29). Measurements throughout the flowpath provide insight into processes such as degassing and limestone dissolution, whereas concentration differences at LRM-000 relate to geochemical changes in the mine workings.

\section{$\underline{\text { Spatial Trends }}$}

Between LRM-SHS and LRM-000, average DIC, Ca, and Mg increase (Figure 29, Table 12). Though the total DIC increase is small, $\mathrm{Ca}$ and $\mathrm{Mg}$ increase substantially before discharging from the mine. Increases in $\mathrm{Ca}$ and $\mathrm{Mg}$ suggest dissolution of impure limestone in the mine workings (Reaction 9).

$$
\mathrm{Ca}_{(1-\mathrm{x})} \mathrm{Mg}_{\mathrm{x}} \mathrm{CO}_{3} \rightleftharpoons(1-\mathrm{x}) \mathrm{Ca}^{2+}+\mathrm{xMg}^{2+}+\mathrm{CO}_{3}^{2-} \quad \text { Reaction } 9
$$

Table 12: Average CaCO -water system concentration changes between LRM-SHS and LRM-000 to illustrate geochemical processes within the mine.

\begin{tabular}{lrr}
\hline Parameter & n & $\begin{array}{r}\text { Average \% } \\
\text { increase }\end{array}$ \\
\hline $\mathrm{DIC}$ & 8 & 4.1 \\
$\mathrm{Ca}$ & 6 & 43.6 \\
$\mathrm{Mg}$ & 6 & 24.5 \\
\hline
\end{tabular}

From LRM-000 to LRM-172, total DIC concentration decreases an average of 88.5\% (Figure 29, Table 13). Ca and Mg concentrations tend to increase from LRM-000 to LRM-172 due to carbonate mineral dissolution (Figure 30, Table 13). 
(A)

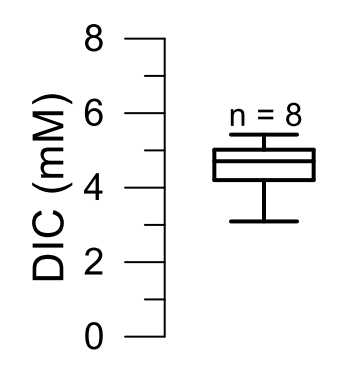
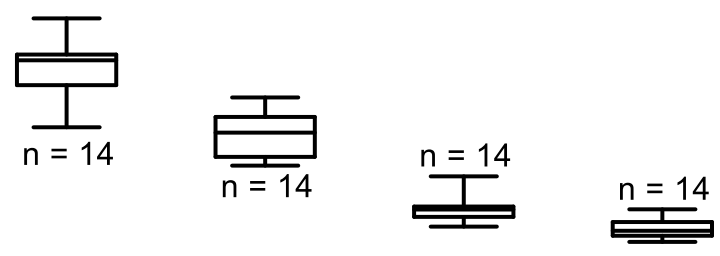

(B)
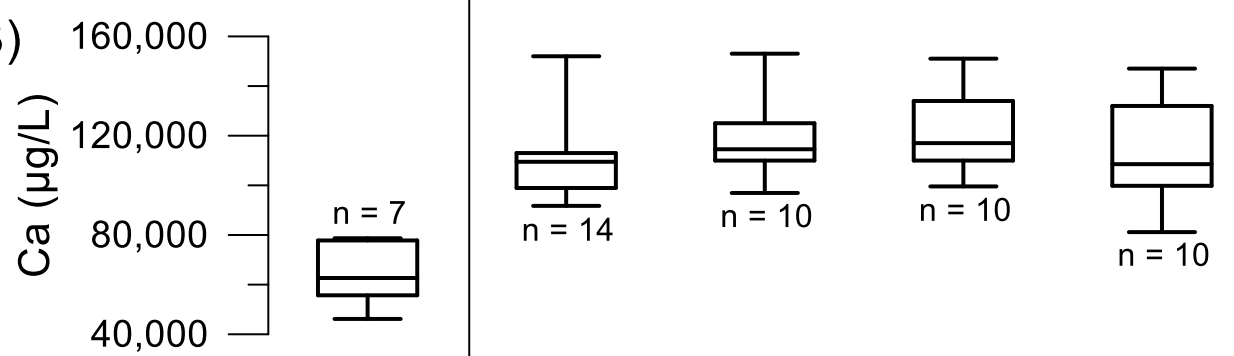

(C)

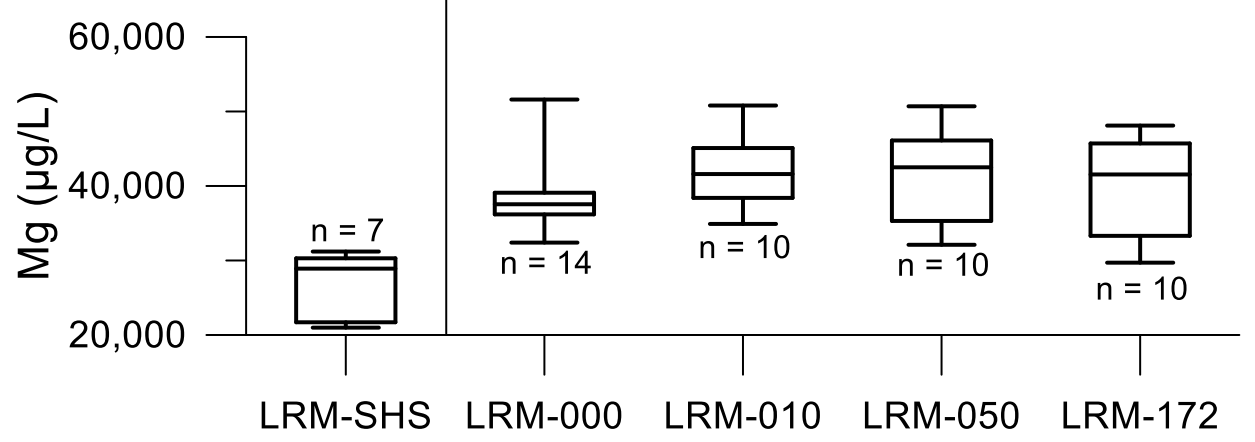

Figure 29: Concentration ranges of (A) DIC, (B), Ca, and (C), Mg at each sampling location. Whiskers represent maximum and minimum values. 
Table 13: Average $\mathrm{CaCO}_{3}$-water system concentration changes between LRM-000 and LRM-172 to indicate geochemical processes active in the treatment system.

\begin{tabular}{lcr}
\hline Parameter & n & $\begin{array}{r}\text { Average \% } \\
\text { change }\end{array}$ \\
\hline $\mathrm{DIC}$ & 14 & -88.5 \\
$\mathrm{Ca}$ & 10 & 3.1 \\
$\mathrm{Mg}$ & 10 & 5.4 \\
\hline $\begin{array}{l}\text { Positive change indicates increase along the } \\
\text { flowpath, negative change indicates removal. }\end{array}$
\end{tabular}

After water discharges at LRM-000, DIC is lost through degassing along the flowpath (Figure 30), however, degassing is not the only control on DIC concentration and pH downstream. For samples collected during diffuse recharge dominated periods, the $\mathrm{pH}$ between LRM-000 and LRM-010 increases faster than if only degassing were governing the $\mathrm{pH}$ of the solution (Figure $30)$.

Degassing lines on Figure 30 are based on carbonate equilibrium at $13^{\circ} \mathrm{C}$ at $5 \mathrm{mmol} / \mathrm{L} \mathrm{DIC}$ and $1.2 \mathrm{mmol} / \mathrm{L}$ DIC (White, 1997). The $\mathrm{PCO}_{2}$ of each sample was calculated using PHREEQC (Parkhurst and Appelo, 2013). The average temperature at LRM-000 is approximately $13^{\circ} \mathrm{C}$, and average DIC concentration during the diffuse recharge dominated period was approximately 5 $\mathrm{mmol} / \mathrm{L}$.

The $5 \mathrm{mmol} / \mathrm{L}$ degassing line illustrates degassing is not the only process controlling DIC concentration between LRM-000 and LRM-010. The $1.2 \mathrm{mmol} / \mathrm{L}$ degassing line shows that DIC concentrations between LRM-010 and LRM-172 generally follow the theoretical trend expected for degassing controlling DIC concentration. Increases in Ca and Mg from LRM-000 to LRM010 suggests dissolution of impure limestone in the channel (Figure 8), adding additional DIC into solution.

\section{Temporal Trends}

Concentration differences at LRM-000 provide insights into geochemical processes acting in the mine. Throughout the study period, total DIC at LRM-000 ranged from 3.26 to $6.18 \mathrm{mmol} / \mathrm{L} \mathrm{C}$. At LRM-000, Ca ranged from 91.7 to $145 \mathrm{mg} / \mathrm{L}, \mathrm{Mg}$ ranged from 32.4 to $48.5 \mathrm{mg} / \mathrm{L}$ (Figure 29).

At LRM-000, DIC is rather consistent when diffuse recharge is dominant, ranging $0.28 \mathrm{mmol} / \mathrm{L}$ $\mathrm{C}(\mathrm{n}=6)$. During the diffuse recharge period, $\mathrm{pH}$ was less than 5.00, so all DIC was measured as dissolved $\mathrm{CO}_{2}$. When direct recharge resumed, DIC concentrations immediately decreased, then trend toward the initial concentrations (Figure 31).

At LRM-000, water temperature and DIC have a strong positive correlation (Figure 32, Table 14). Correlation exists during both direct and diffuse recharge dominated regimes (Table 14). The trend is only observable at the point of discharge (i.e. the outflow pipe). Similar positive correlations were noted by Troester and White (1984) in the atmosphere of Tytoona cave, though 


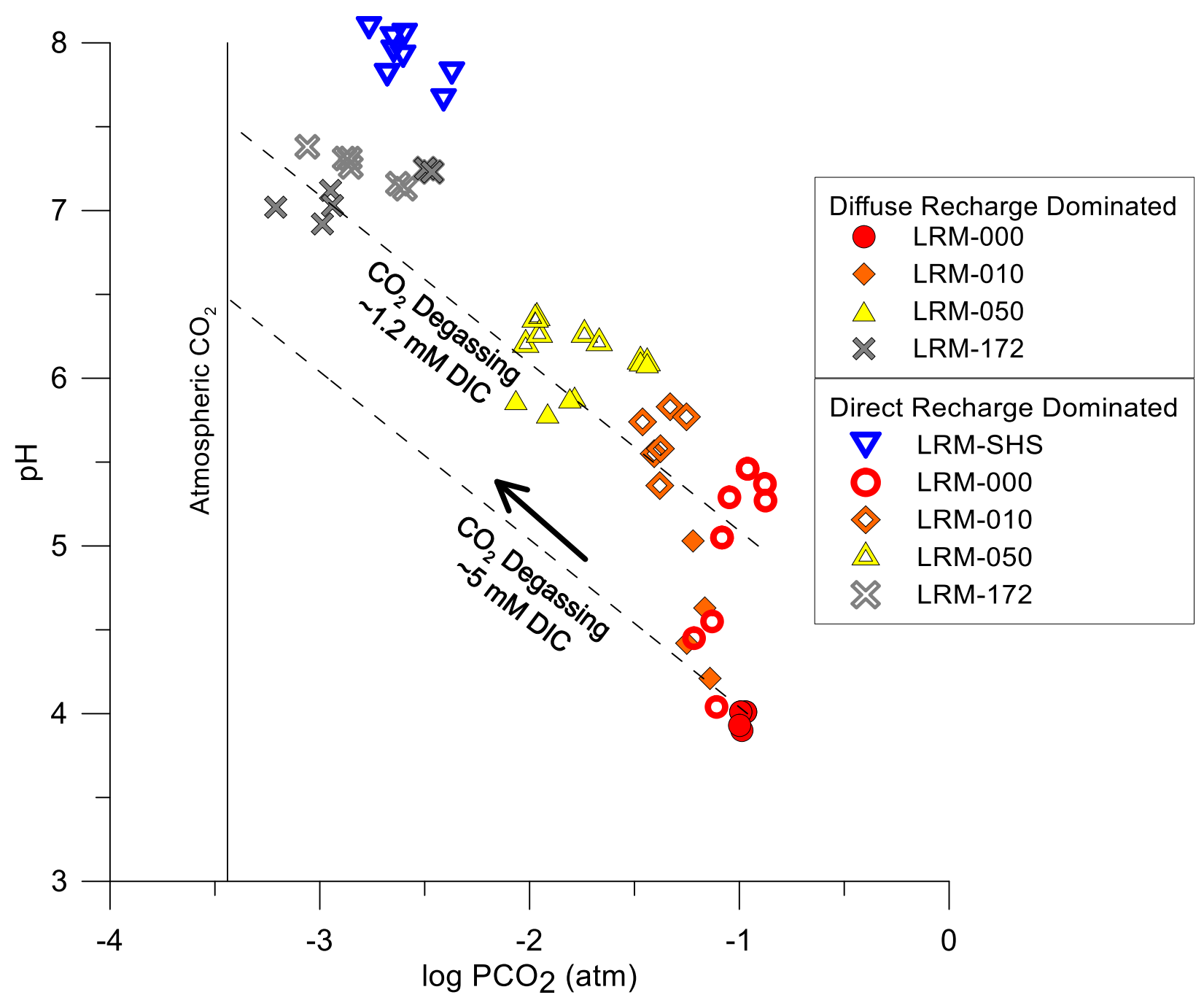

Figure 30: Spatial variation in PCO2 and pH during the study period. 


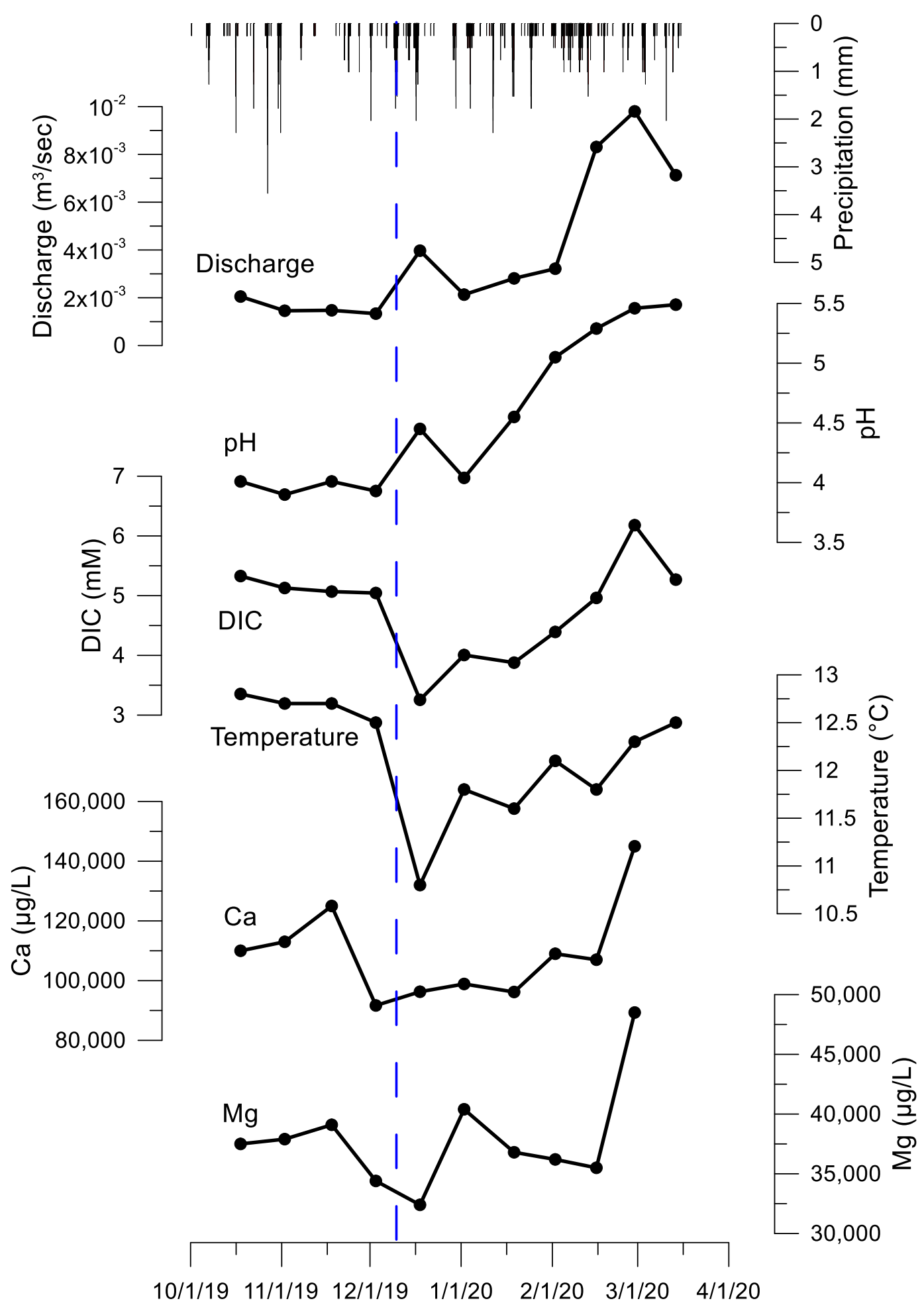

Figure 31: Temporal variations in DIC, temperature and pH at LRM-000. Dashed line indicates division between diffuse recharge dominated (left) and direct recharge dominated (right) periods. 


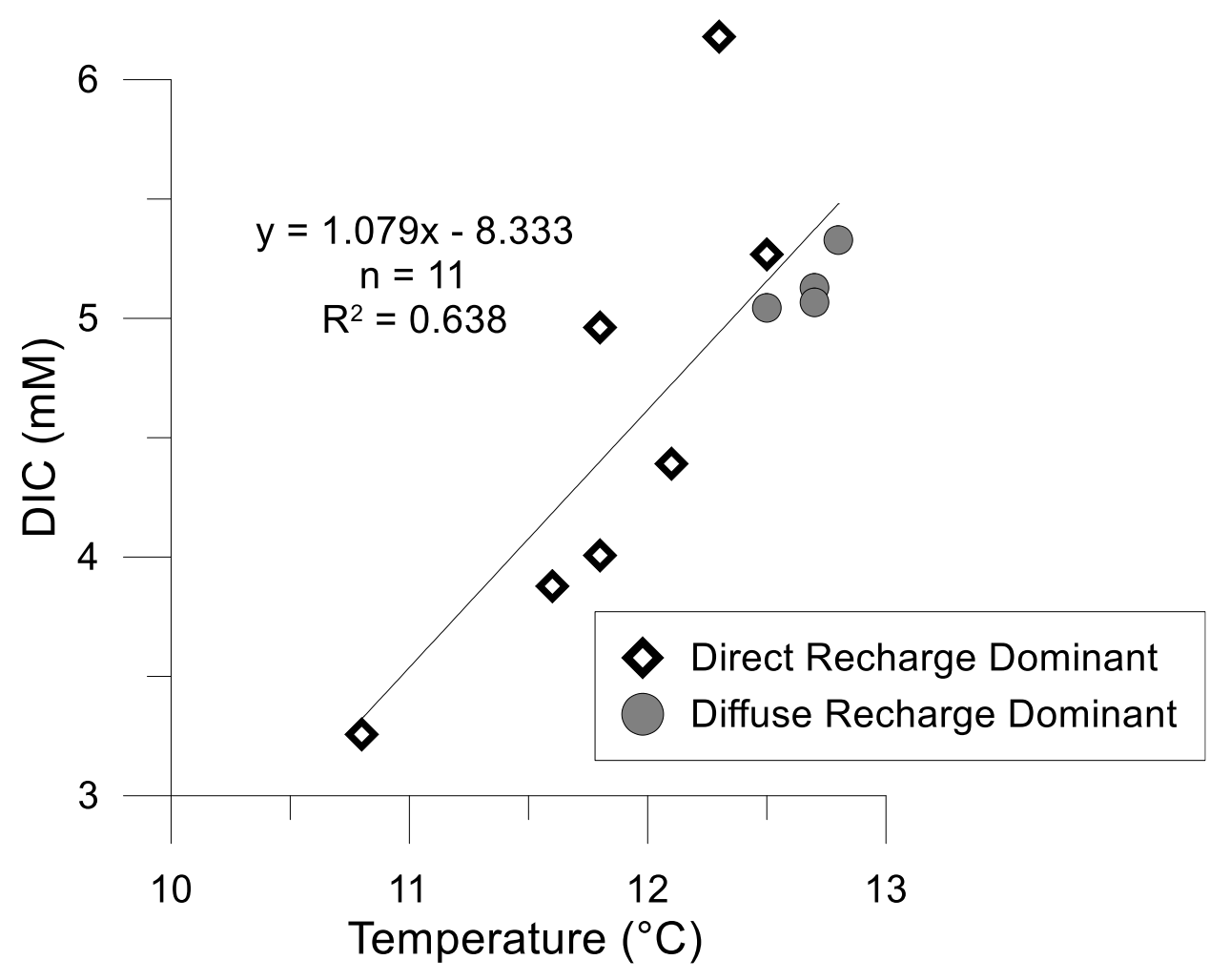

Figure 32: Correlation between temperature and DIC at LRM-000. Only includes samples collected directly from outflow pipe. Best fit line includes all samples. 
Table 14: Correlations to DIC at LRM-000.

\begin{tabular}{lc|c|cc}
\hline Parameter & & $\begin{array}{c}\text { All } \\
\text { Samples }\end{array}$ & $\begin{array}{c}\text { Diffuse } \\
\text { Recharge } \\
\text { Dominated } \\
\text { n=6 }\end{array}$ & $\begin{array}{c}\text { Direct } \\
\text { Recharge } \\
\text { Dominated } \\
\text { n=8 }\end{array}$ \\
\hline \multirow{2}{*}{ Temperature } & R & $\mathbf{0 . 7 2 8}$ & $\mathbf{0 . 7 4 5}$ & $\mathbf{0 . 7 6 8}$ \\
& $\mathrm{p}$ & $\mathbf{0 . 0 0 1}$ & $\mathbf{0 . 0 3 4}$ & $\mathbf{0 . 0 0 9}$ \\
\hline \multirow{2}{*}{$\mathrm{pH}$} & $\mathrm{R}$ & 0.220 & 0.257 & $\mathbf{0 . 7 7 3}$ \\
& $\mathrm{p}$ & 0.380 & 0.539 & $\mathbf{0 . 0 0 9}$ \\
\hline \multirow{2}{*}{$\mathrm{SC}$} & $\mathrm{R}$ & $\mathbf{0 . 8 5 0}$ & -0.415 & $\mathbf{0 . 9 3 6}$ \\
& $\mathrm{p}$ & $\mathbf{0 . 0 0 0}$ & 0.307 & $\mathbf{0 . 0 0 0}$ \\
$\mathrm{N} \mathrm{Ca}$ & $\mathrm{R}$ & $\mathbf{0 . 7 8 1}$ & 0.150 & $\mathbf{0 . 9 4 7}$ \\
& $\mathrm{p}$ & $\mathbf{0 . 0 0 1}$ & 0.776 & $\mathbf{0 . 0 0 0}$ \\
\multirow{2}{*}{$\mathrm{Mg}$} & $\mathrm{R}$ & $\mathbf{0 . 7 2 4}$ & 0.083 & $\mathbf{0 . 8 7 7}$ \\
& $\mathrm{p}$ & $\mathbf{0 . 0 0 3}$ & 0.875 & $\mathbf{0 . 0 0 4}$ \\
\multirow{2}{*}{ Discharge } & $\mathrm{R}$ & 0.426 & $\mathbf{0 . 9 5 7}$ & $\mathbf{0 . 8 1 0}$ \\
& $\mathrm{p}$ & 0.078 & $\mathbf{0 . 0 0 0}$ & $\mathbf{0 . 0 0 4}$ \\
\hline
\end{tabular}

Shaded and bolded values indicate $p<0.05$. Pearson correlation values and p values calculated using MINITAB 18 statistical software. 
the concentration of DIC is much higher at LRM. At Tytoona cave, the highest $\mathrm{CO}_{2}$ concentrations occurred in the late summer, when $\mathrm{CO}_{2}$ production in the soil zone is greatest. Lowest concentrations occurred in the winter, when little $\mathrm{CO}_{2}$ production is occurring (Troester and White, 1984).

Lloyd and Taylor (1994) provide a summary of multiple methods used for calculating the effect of temperature on respiration rate in soil. The summary of methods indicate that temperature variations measured at LRM-000 $\left(10.5^{\circ} \mathrm{C}-13^{\circ} \mathrm{C}\right)$ can nearly double the respiration rate expected at $10^{\circ} \mathrm{C}$. The calculated respiration rates vary depending on the specific metabolic pathway, but the overall exponential trend remains regardless of the calculation method or biochemistry of the soil system. It is likely that respiration of microorganisms in the mine system play a role in the seasonal variation of DIC observed at LRM-000.

\subsection{Net Acidity}

\section{Parameter Range}

Using laboratory and field measurements, potential acidity (Equation 3) and carbonate alkalinity (Equation 4) were calculated for each sampling event. Comparing calculated acidity and carbonate alkalinity provides insight into the dominant processes acting at LRM along the flowpath and under different recharge systems. Net acidity is often calculated in CMD studies to evaluate whether sufficient alkalinity has been added to balance potential acidity generated from hydrolysis of dissolved metals (Equation 6).

$$
\text { Net Acidity }=\text { Potential Acidity } \text { Calc }_{1}+\text { Carbonate Alkalinty } \text { Calc }_{\text {Cation }} 6
$$

Where calculated potential acidity (Equation 3) and carbonate alkalinity (Equation 4) are in comparable units (e.g. meq/L). Positive values indicate excess potential acidity (i.e. net acidic), whereas negative values indicate excess carbonate alkalinity (i.e. net alkaline).

LRM-SHS is the most net alkaline sample location, with an average net acidity of $-3.75 \mathrm{meq} / \mathrm{L}$. LRM-000 averages a net acidity of $0.21 \mathrm{meq} / \mathrm{L}$. From LRM-000 to LRM-172, the system becomes increasingly net alkaline (Figure 33).

\section{$\underline{\text { Spatial Trends }}$}

Along the LRM flowpath, alkalinity is added through the dissolution of limestone and increasing $\mathrm{pH}$. Increasing $\mathrm{pH}$ causes $\mathrm{H}_{2} \mathrm{CO}_{3}{ }^{*}$ to become $\mathrm{HCO}_{3}$ further downstream, adding alkalinity in the process (Figure 4). Concentrations of $\mathrm{Fe}, \mathrm{Al}$, and $\mathrm{Mn}$ decrease along the flowpath, resulting in less potential acidity further downstream. The balance between potential acidity and carbonate alkalinity results in LRM being net-alkaline before leaving the treatment system (Figure 33).

\section{$\underline{\text { Temporal Trends }}$}

When direct recharge was dominant, decreased hydrolysable metal concentrations and increased $\mathrm{pH}$ cause a decrease in net acidity at LRM-000. The inverse relationship of discharge to acidity is consistent with observations by Mack et al. (2015). The decrease in net acidity at LRM-000 
with direct recharge propagates downstream. When direct recharge was dominant, LRM becomes net-alkaline earlier in the flowpath (Figure 34). Near the end of the sample period, LRM-000 was net alkaline (Figure 35). 


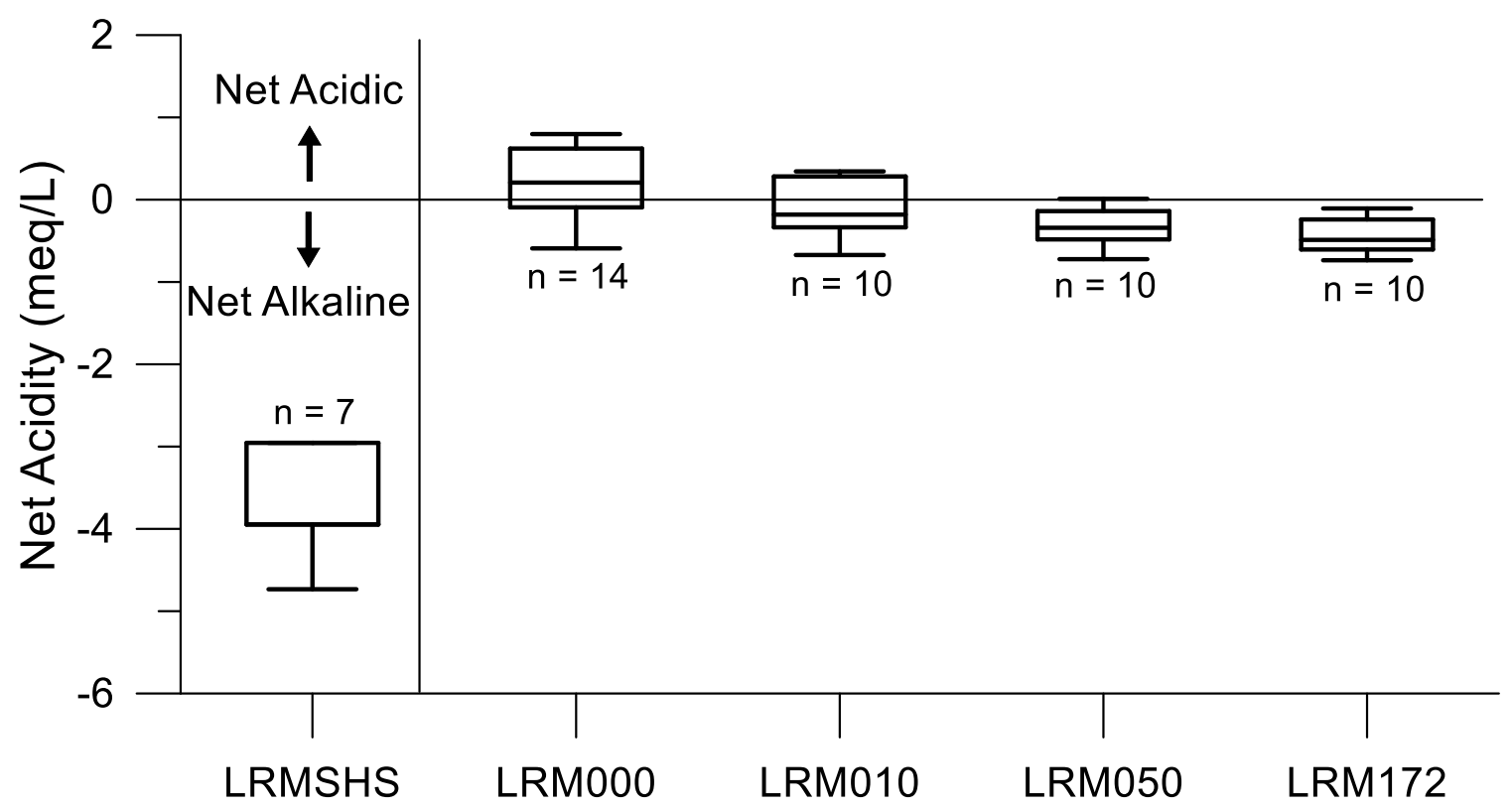

Figure 33: Net acidity range at each sample location. Whiskers represent maximum and minimum values. 


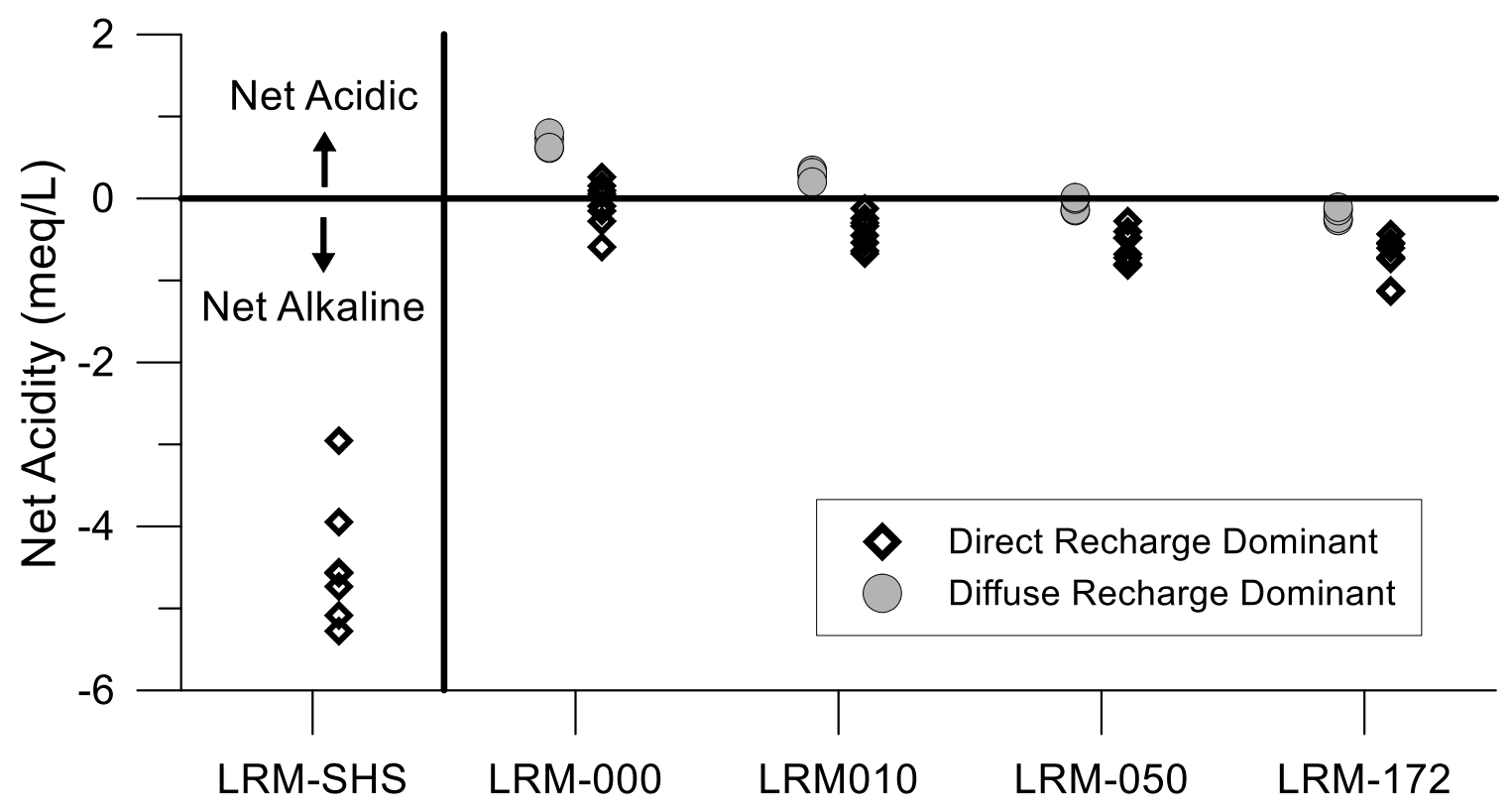

Figure 34: Net acidity variability relative to dominant recharge type. 


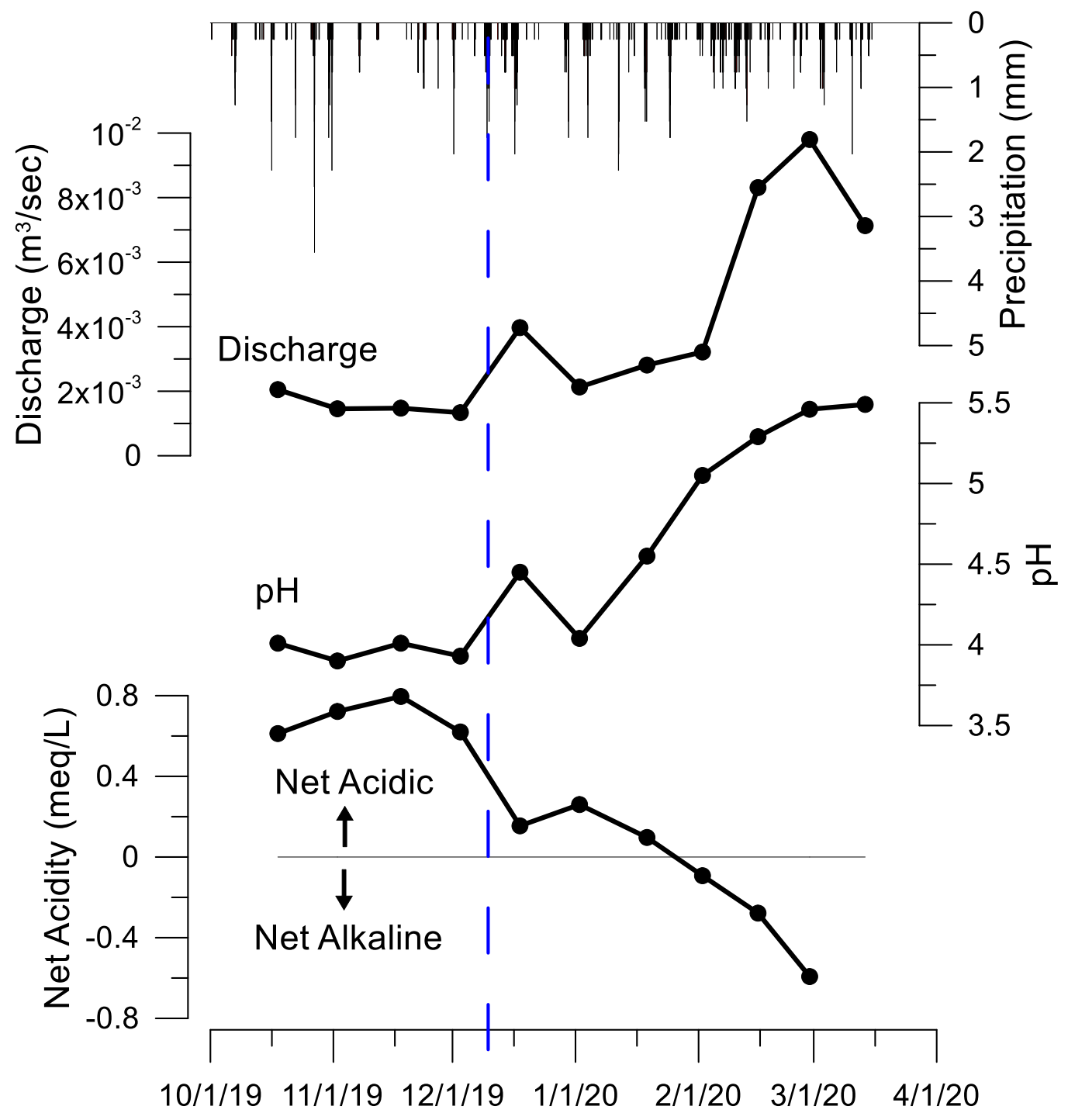

Figure 35: Temporal variation of net acidity at LRM-000 throughout the study period. Dashed line indicates division between diffuse recharge dominated (left) and direct recharge dominated (right) periods. 


\subsection{Discussion and Interpretation}

\subsection{Hydrologic Influences on CMD Discharge Chemistry}

At LRM, the dominant type of recharge entering the mine influences the outflow chemistry. All CMD parameter concentrations decrease at LRM-000 when direct recharge is dominant (Table 9). Decreased concentrations at LRM-000 propagate downstream, resulting in lower concentrations of CMD parameters throughout the flowpath. Decreased concentrations of hydrolysable metals causes potential acidity to decrease, leading to LRM being a net-alkaline discharge earlier in the flowpath (Figure 34). After 2/1/2020, LRM-000 was net alkaline (Figure $35)$.

CMD cation concentrations at LRM-000 are within the range of bituminous CMD outflows in Pennsylvania, as reported by Cravotta (2008) (Figure 36). The data from Cravotta (2008) likely represents a range of hydrogeologic characteristics, based on the shallow dip characteristic for much of the Appalachian Plateau. Hydrolysable metal concentrations at LRM decrease as much as one order of magnitude when direct recharge is dominant, whereas $\mathrm{Ca}$ and $\mathrm{Mg}$ remain near the median value of the Cravotta dataset (Figure 36).

With greater volumes of recharge entering the mine when direct recharge is dominant, dilution of the outflow is likely to occur. Using $\mathrm{SO}_{4}$, which behaves approximately conservatively at LRM (Table 7), dilution factors were calculated for samples collected after 12/9/2019 (Figure 37). Concentrations expected from dilution calculated using dilution factors assumes the parameter of interest is conservative, which is not true of Fe, $\mathrm{Al}$, and Mn. For each of these constituents, the conservative dilution concentration is greater than the measured concentration (Figure 37), indicating removal and sequestration of the metals in the mine workings. Fe and $\mathrm{Al}$ are consistently sequestered, whereas Mn sequestration is less consistent. This inconsistency could be due to Mn sorption to hydrous ferric oxides (HFOs) or mineral surface catalyzed precipitation, which could change as a result of $\mathrm{pH}$, temperature, sorbent concentration, and mineral surface presence (Dzombak and Morel, 1990; Stumm and Morgan, 1996).

Sequestration in the mine workings is likely not stable in the long term. Future changes in recharge type will alter the chemistry in the mine workings, resolubilizing metals stored in secondary mineral forms. Metals may also be removed in the mine workings through sorption onto amorphous hydroxide minerals. Removal and re-release of sorbed metals would be much more difficult to predict than solubility-controlled removal.

The range of $\mathrm{pH}$ at LRM-000 and LRM-010 illustrates a balance between two competing systems early in the surface flowpath; the lowering of $\mathrm{pH}$ from hydrolysis of dissolved metals and the raising of $\mathrm{pH}$ from the dissolution of carbonate minerals and $\mathrm{CO}_{2}$ degassing. When diffuse recharge is dominant, dissolved metals concentrations are highest and $\mathrm{pH}$ is lowest (Figure 15, Figure 9). Diffuse recharge dominated samples are also more undersaturated with respect to calcite (Figure 38), so dissolution of carbonate minerals in the remediated channel exceeds the effects of metal hydrolysis before reaching LRM-050. When direct recharge is dominant, metal concentrations at the portal are low, $\mathrm{pH}$ is higher, and the system has a higher $\mathrm{SI}_{\text {calcite }}$ (Figure 38). During this period, impure limestone is dissolved in the channel, and $\mathrm{PCO}_{2}$ 
vs $\mathrm{pH}$ trends early in the surface flowpath more closely follow the theoretical degassing line (Figure 30).

\subsection{YREE Removal by Passive Treatment System}

Due to the economic importance of YREE and limited world supplies, YREE capture in CMD treatment systems has been the focus of recent research (Rozelle et al., 2016; Stewart et al., 2017; Hedin et al., 2019). Understanding the sources, removal mechanisms, and extraction from CMD precipitates is crucial to the future development of domestic YREE reserves (DOE, 2011).

NASC normalized (Gromet et al., 1984) concentrations of YREE at LRM are comparable to other similar CMD locations in West Virginia and Pennsylvania. Total YREE concentrations at LRM decreased with increasing $\mathrm{pH}$ (Figure 40), as noted by other studies of YREE in CMD systems (Stewart et al., 2017; Hedin et al., 2019). Throughout the study period, 97\% of total YREE were removed between LRM-000 and LRM-172 $(n=10)$. Throughout the study period, energy critical YREE mass removed per year was calculated (Table 15). Annual removal was extrapolated from averaged daily removal of each element, assuming discharge during each sample event was consistent for the entire day (Equation 7). Estimated annual critical YREE removal was higher at LRM than the treatment systems studied by Hedin et al. (2019) (Table 15). It is important to note the data for LRM includes a series of remediation measures (limestone-lined channel and altered natural wetland), rather than influent and effluent grab samples of a single remediation technology. Extrapolations of discharge data to calculate yearly removal from Hedin et al. does not account for seasonal variations in discharge and YREE mass removal (2019).

YREE Removed $\left(\frac{g}{\text { day }}\right)=$ YREE Removed $\left(\frac{g}{L}\right) *$ Discharge $\left(\frac{L}{\sec }\right) * \frac{86,400 \mathrm{sec}}{1 \text { day }} \quad$ Equation 7

Table 15: Average mass of energy critical YREE removed per year at LRM.

\begin{tabular}{l|c|cccccc}
\hline \multicolumn{7}{c}{ Mass removed (g/yr) } \\
\hline \multirow{2}{*}{ Element } & $\begin{array}{c}\text { This Study } \\
\text { n=10 }\end{array}$ & LP-1 & VFP-1 & VFP-2 & DLB-1 & DLB-2 & DLB-3 \\
\hline $\mathrm{Y}$ & 185 & 6.4 & 4.4 & 14.7 & 0.6 & 10.1 & 5.6 \\
$\mathrm{Nd}$ & 73.0 & 3.3 & 2.4 & 13.1 & 0.7 & 4.9 & 3.2 \\
$\mathrm{Dy}$ & 35.9 & 1.48 & 1.03 & 3.16 & 0.14 & 1.74 & 1.01 \\
$\mathrm{Eu}$ & 6.47 & 0.34 & 0.21 & 0.80 & 0.05 & 0.33 & 0.25 \\
$\mathrm{~Tb}$ & 6.75 & 0.31 & 0.21 & 0.57 & 0.03 & 0.35 & 0.21 \\
\hline
\end{tabular}




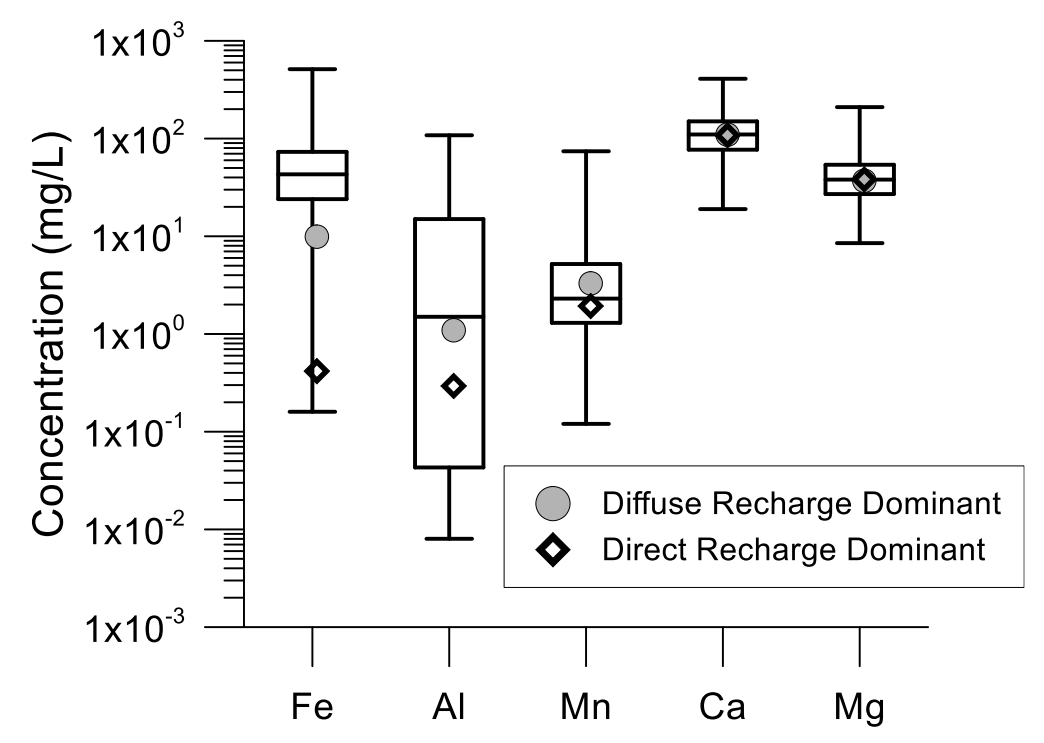

Figure 36: Average concentrations at LRM-000 during diffuse and direct recharge dominated periods compared to bituminous coal mine outflow concentration ranges from Cravotta (2008). Whiskers represent minimum and maximum concentrations. 


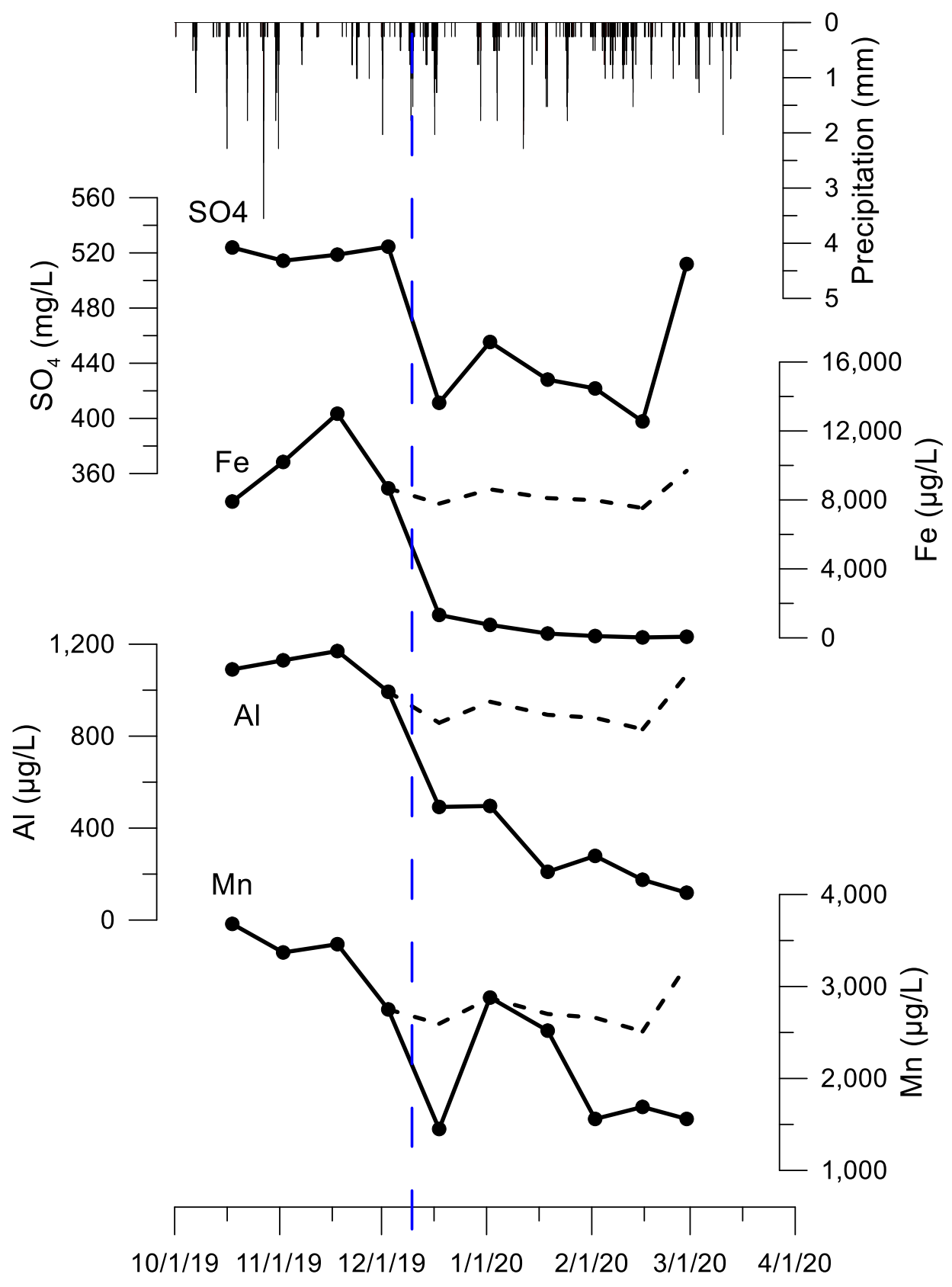

Figure 37: Concentrations expected from conservative dilution (dashed lines) of CMD constituents at LRM-000. Vertical dashed line indicates division between diffuse recharge dominated (left) and direct recharge dominated (right) periods. 


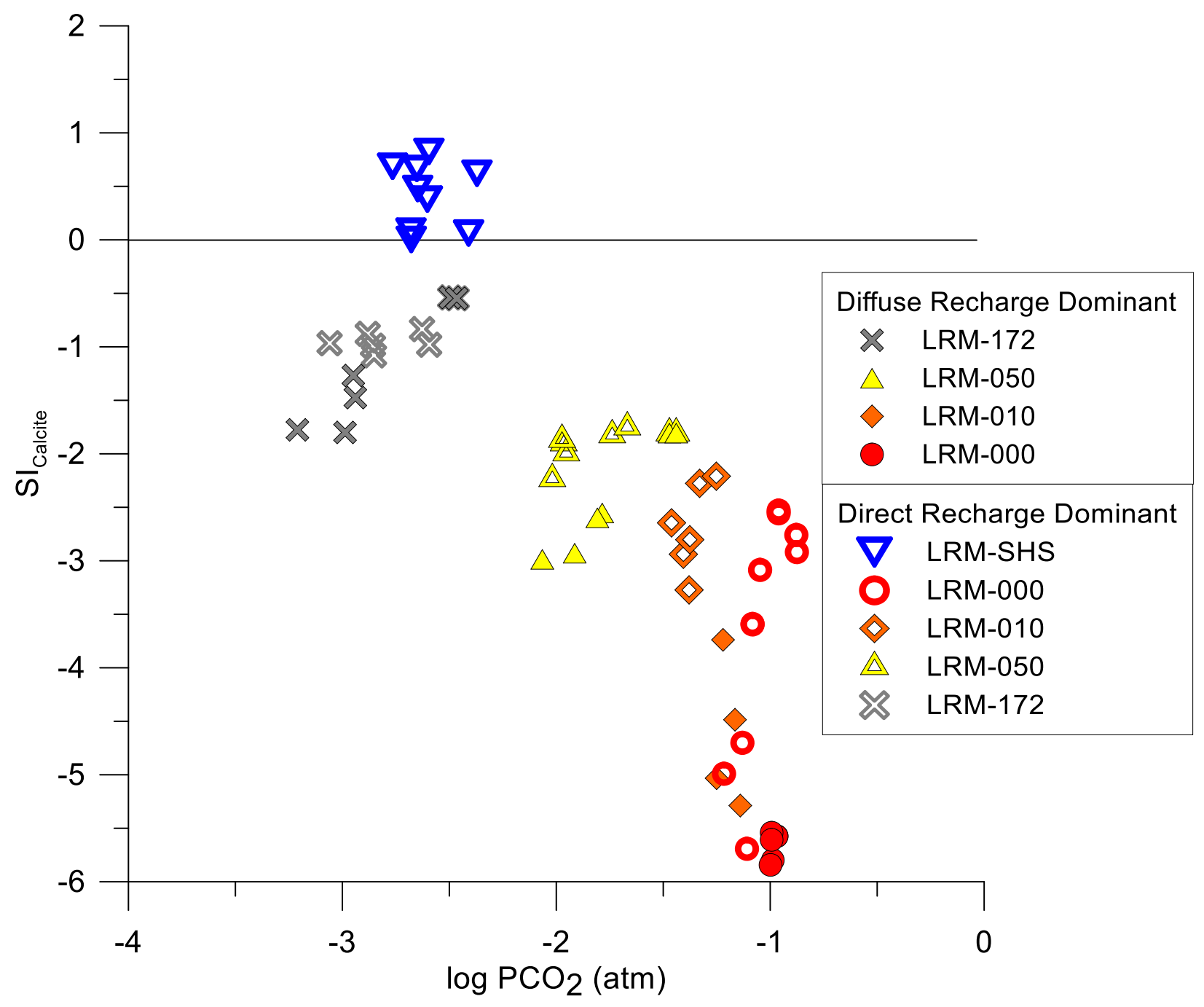

Figure 38: Spatial variation in PCO2 vs $S_{\text {calcite }}$ during the study period. 


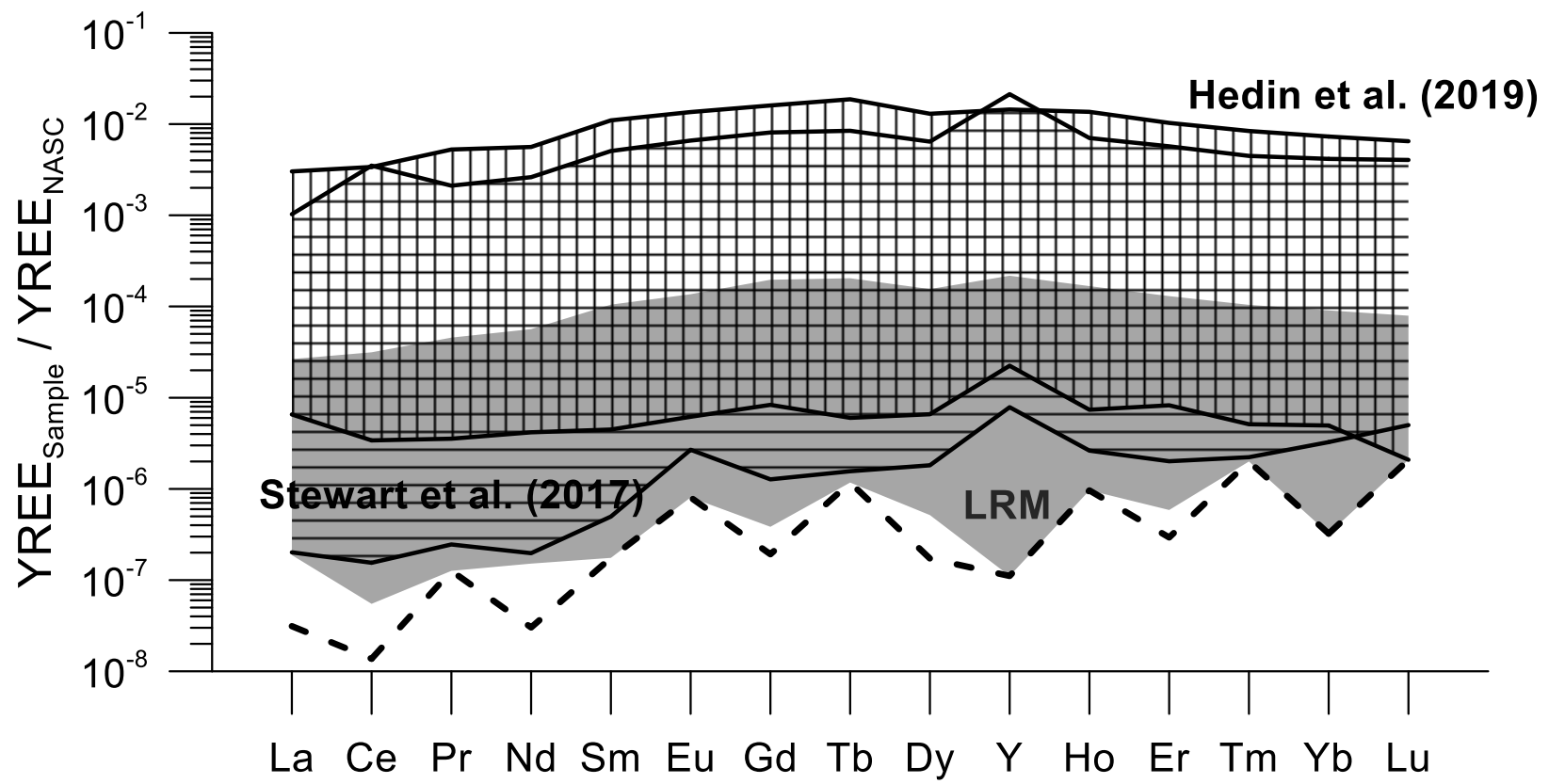

Figure 39: Normalized concentration ranges at LRM compared to concentrations from Stewart et al. (2017) and Hedin et al. (2019). Concentration ranges from Stewart et al. are hatched with horizontal lines. Concentrations from Hedin et al. are hatched with vertical lines. LRM concentrations shown in grey. Samples with concentrations below detection are displayed as the normalized MDL concentration. MDL shown as black dashed line. 


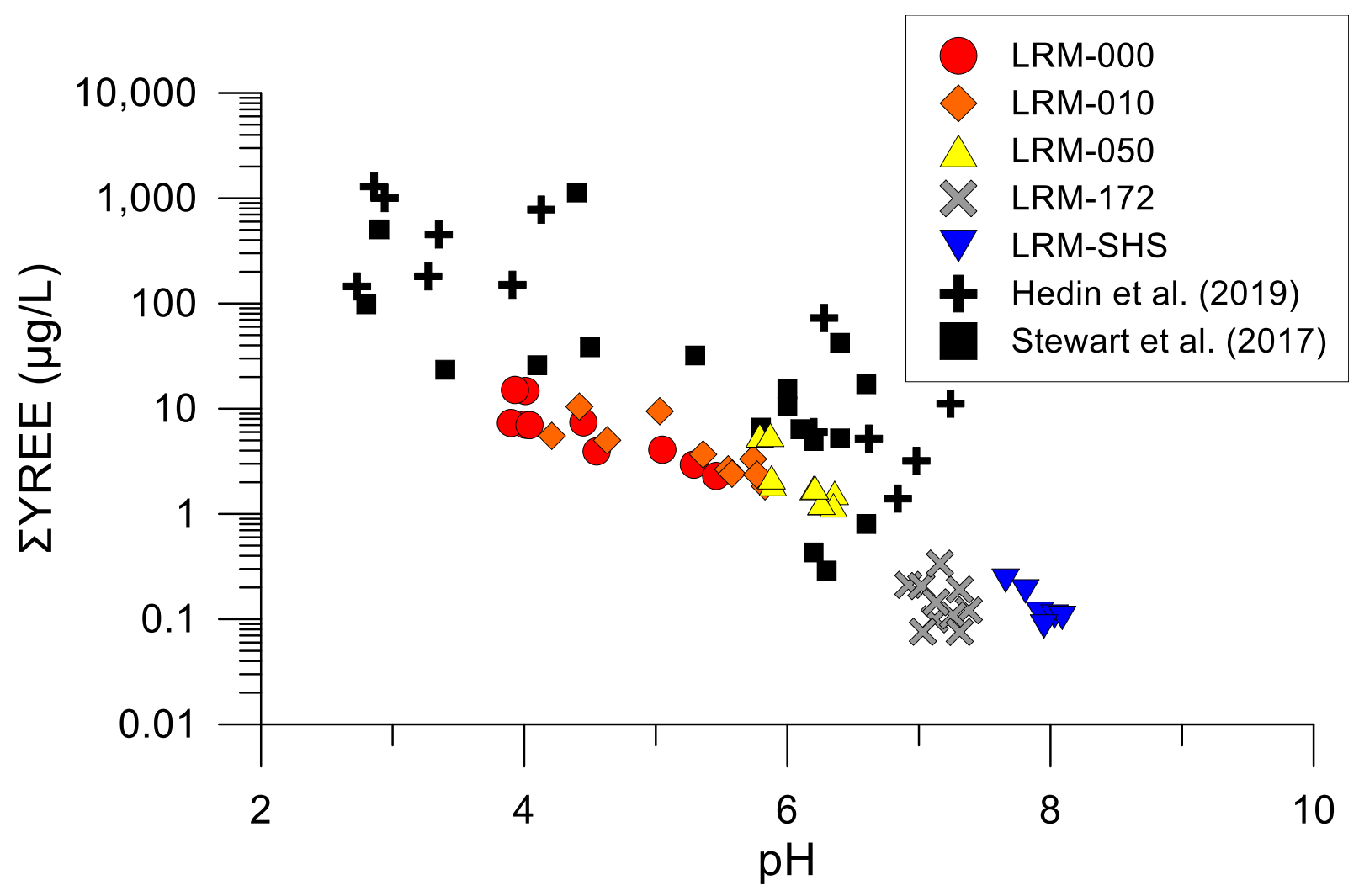

Figure 40: YREE concentration relative to $p H$ at LRM compared to supplemental data from Stewart et al. (2017) and Hedin et al. (2019). Data from Stewart et al. (2017) are from 18 bituminous CMD outflows throughout Pennsylvania. Data from Hedin et al. (2019) are treated and untreated CMD samples from four different passive treatment systems. 
At LRM, HREE are preferentially removed compared to MREE and LREE along the flowpath (Figure 41). Complexation and sorption to oxide minerals are generally considered to be the major factors influencing the removal of YREE in CMD settings (Hedin et al., 2019).

To illustrate processes such as sorption and oxidation of YREE along the flowpath, several YREE anomalies were calculated using the following equations from Lawrence at al. (2006).

$$
\begin{array}{ll}
Y R E E \text { Anomaly }=\frac{Y R E E_{n}}{Y R E E_{n}{ }^{*}} & \text { Equation } 8 \\
L a_{n}{ }^{*}=P r_{n}+2 *\left(P r_{n}-N d_{n}\right) & \text { Equation } 9 \\
C e_{n}{ }^{*}=P r_{n}+\left(P r_{n}-N d_{n}\right) & \text { Equation } 10
\end{array}
$$

Where YREE $\mathrm{n}$ is the YREE concentration normalized to NASC (Gromet et al., 1984), and $\mathrm{YREE}_{\mathrm{n}} *$ is the theoretical normalized element concentration calculated from neighboring element concentrations. The unnormalized Y/Ho molar ratio was also calculated to provide insight into sorption processes. Preferential removal of Ho compared to $\mathrm{Y}$ indicates sorption onto HFO, whereas a low Ce anomaly value indicates oxidation and removal. Normalized La/Ce ratio was also calculated to illustrate preferential removal of $\mathrm{Ce}$.

Along the flowpath sorption occurs, as indicated by an increasing Y/Ho ratio (Figure 42). Y/Ho is more variable when diffuse recharge is dominant, likely due to variations in Y concentrations along the flowpath during the study period (Figure 25 and Figure 26). Ce oxidation occurs along the flowpath during both direct and diffuse recharge periods, though $\mathrm{Ce}$ is removed earlier in the flowpath when direct recharge is dominant, likely due to aerated, high $\mathrm{pH}$ water entering the mine and outflow channel (Figure 15). Regardless of the dominant recharge type, $\mathrm{Ce}_{\mathrm{n}} / \mathrm{Ce}_{\mathrm{n}}{ }^{*}$ and $\mathrm{La}_{\mathrm{n}} / \mathrm{Ce}_{\mathrm{n}}$ ratios at LRM-172 are comparable (Figure 42).

\section{3 $\mathrm{CO}_{2}$ Evasion and DIC Flux}

Along the treatment system flowpath, total DIC decreases (Figure 29, Table 13). Between LRM000 to LRM-172, DIC has two major sources, DIC discharged at LRM-000 and DIC added to solution from the dissolution of impure limestone along the flowpath (Reaction 9). Following dissolution, $\mathrm{CO}_{3}$ ions are speciated based on solution $\mathrm{pH}$ (Reactions 7 and 8). Using dissolved $\mathrm{Ca}$ and $\mathrm{Mg}$ concentrations, the amount of DIC from impure limestone dissolution between sample locations can be calculated (Equation 11).

$$
[D I C]_{\text {Dissol. }}=[C a+M g]_{\text {Downstream }}-[C a+M g]_{\text {Upstream }}
$$

Equation 11

Where $[\mathrm{Ca}+\mathrm{Mg}]_{\text {Upstream }}$ is the sum of $\mathrm{Ca}$ and $\mathrm{Mg}$ molar concentrations at the upstream sample

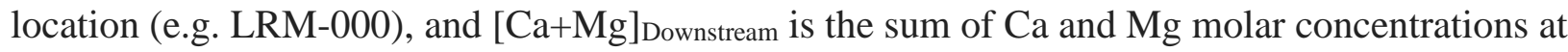
the downstream sample location (e.g. LRM-172). Once DIC from limestone dissolution is known, the amount of DIC degassed between sample locations is calculated using a mass balance equation (Equation 12).

$$
[D I C]_{\text {Downstream }}=[D I C]_{\text {Upstream }}+[D I C]_{\text {Dissol. }}-[D I C]_{\text {Degas. }}
$$

Equation 12

Where subscripts indicate molar DIC concentrations from limestone dissolution and degassing, and measured molar concentrations at upstream and downstream sample locations. 

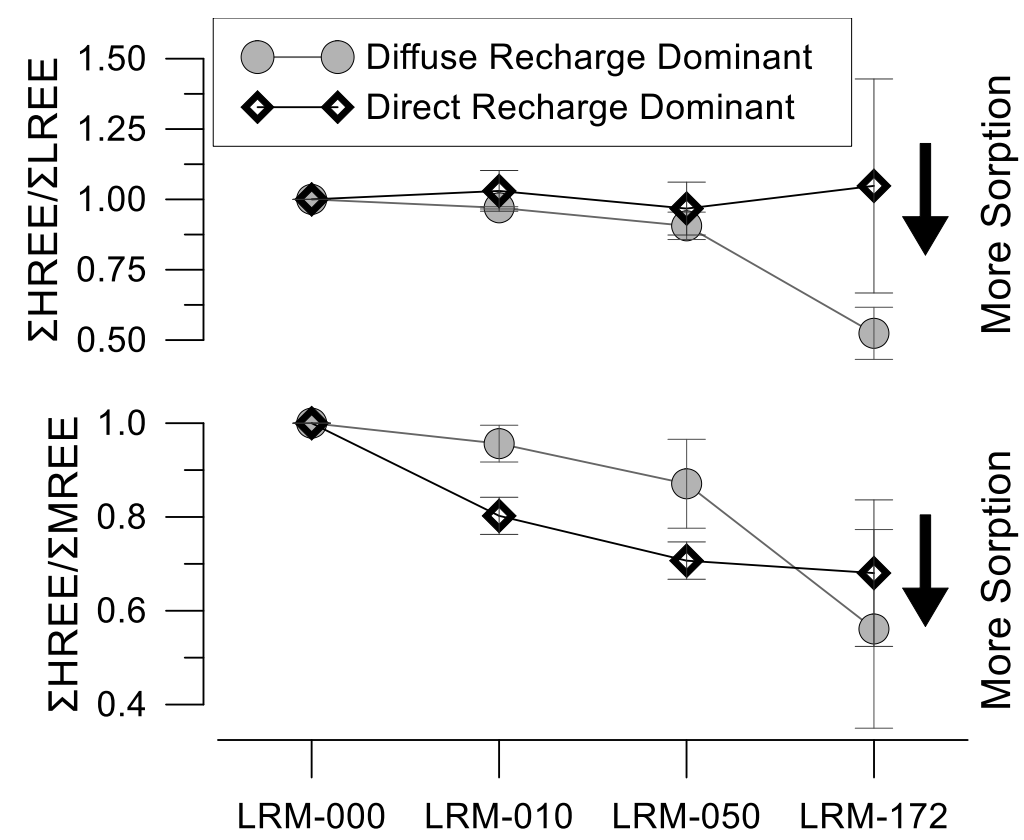

Figure 41: YREE removal ratios normalized to LRM-000. Points are average values at each location, error bars are the standard deviation. 

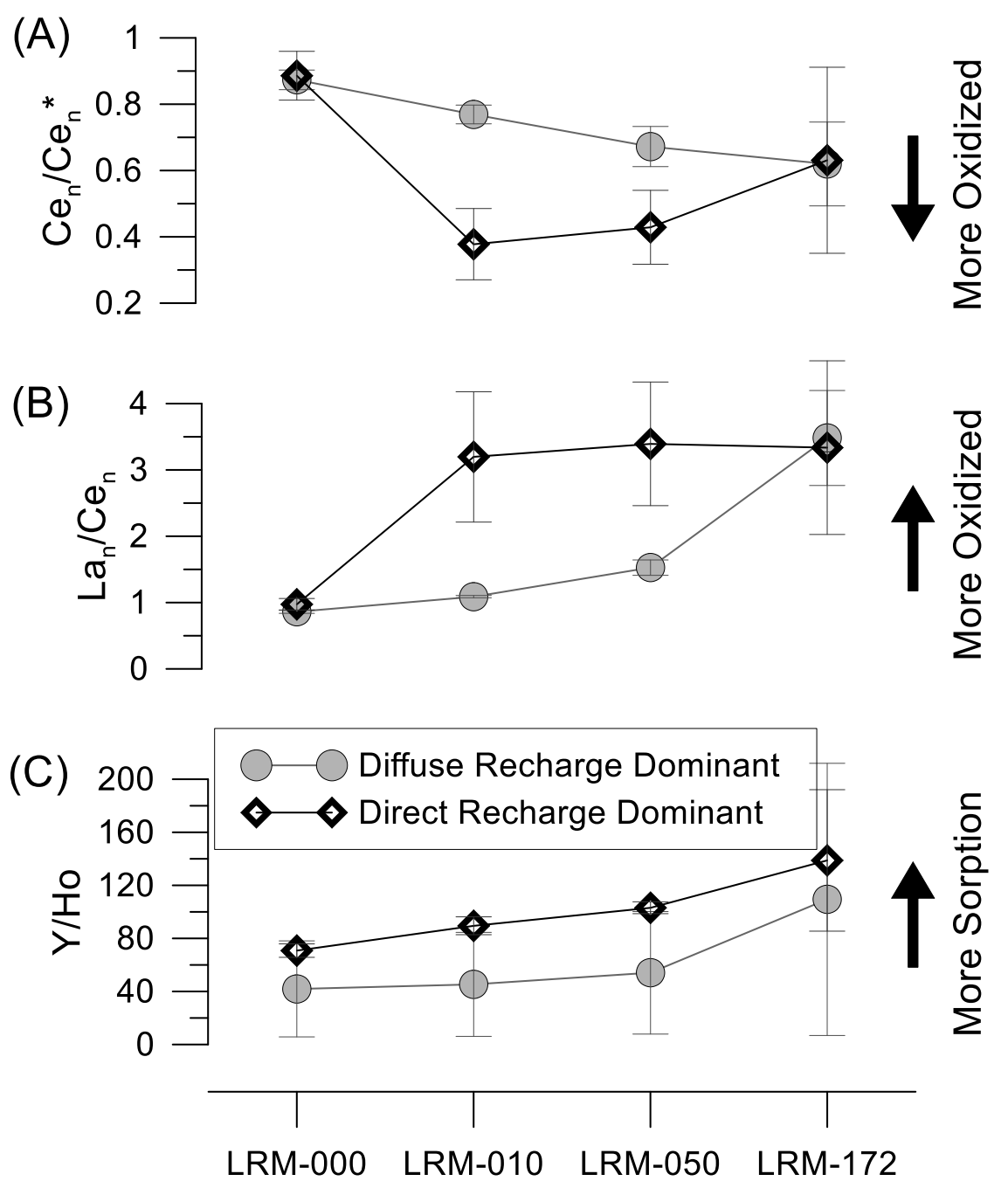

Figure 42: Spatial variation in (A) Ce anomaly, (B) La/Ce normalized ratio, and (C) Y/Ho unnormalized molar ratio. Where subscript $n$ indicates normalization to NASC (Gromet et al., 1984). Points are average values at each location, error bars are the standard deviation. 
Total $\mathrm{CO}_{2}$ efflux between LRM-000 and LRM-172 ranged from $29.3 \mathrm{~kg} \mathrm{CO} /$ day to $200 \mathrm{~kg}$ $\mathrm{CO}_{2}$ /day during the study period (Figure 43). Averaging these fluxes by month and extrapolating for an entire year results in 23.2 metric tons $\mathrm{CO}_{2} /$ year degassed directly to the atmosphere. Vesper et al. (2016) estimated 17.8 metric tons $\mathrm{CO}_{2} /$ year degassed at LRM. The direct release of $\mathrm{CO}_{2}$ to the atmosphere occurs on more rapid timescales than $\mathrm{HCO}_{3}$ transported to the ocean and needs to be addressed in global carbon cycle and climate models.

Using Equation 12, the contribution of DIC sources and sinks were calculated from LRM-000 to LRM-172 for each sample date (Figure 44). During both diffuse and direct recharge dominated periods, most DIC present in the system is degassed to the atmosphere. DIC from limestone dissolution in the channel is more prevalent when diffuse recharge is dominant because discharging water is more undersaturated with respect to calcite (Figure 38).

Vesper et al. (2016) calculated $\mathrm{CO}_{2}$ flux at LRM based on two sampling events in August 2012 and July 2013. It is unknown whether LRM-SHS was entering the mine during this time, or what the dominant type of recharge was during sampling. Discharge measured during these sampling events was comparable to the discharge range throughout this study. DIC sources and sinks for both calculated sampling events were within the ranges of calculated sources and sinks from this sampling effort (Figure 45). Compared to $\mathrm{CO}_{2}$ fluxes of coal fired power plants in West Virginia, the $\mathrm{CO}_{2}$ flux from LRM was minor (Vesper et al., 2016). $\mathrm{CO}_{2}$ flux at LRM was within the wide range calculated by Vesper et al.(2016) using CMD data throughout Pennsylvania from Cravotta (2008) and Kirby and Cravotta (2005).

Studies of mountain top removal/valley fill (MTR/VF) coal operations in West Virginia have noted "exceptionally high" weathering rates of geologic $\mathrm{CO}_{2}$, based on $\mathrm{HCO}_{3}: \mathrm{SO}_{4}$ ratios of circumneutral valley fill outflows (Ross et al., 2018). $\mathrm{CO}_{2}$ efflux ranged from 10-45 $\mathrm{gC} \cdot \mathrm{m}^{-2}$ • $\mathrm{yr}^{-1}$, only considering $\mathrm{CO}_{2}$ directly degassed to the atmosphere. When $\mathrm{HCO}_{3}$ exported to the ocean was considered, flux ranged from 90-145 $\mathrm{gC} \cdot \mathrm{m}^{-2} \bullet \mathrm{yr}^{-1}$. Ross et al. considered efflux relative to a unit area, in order to apply flux estimates across broad reaches of MTR/VF mine operations (2018). LRM CO 2 efflux is two orders of magnitude higher when considering only the area of the outflow channel and altered natural wetland (Figure 46). When extrapolating LRM efflux to the entire Dawson No. 3 mine ( 8 outflows, $7.6 \mathrm{~km}^{2}$ total area), assuming $\mathrm{CO}_{2}$ flux at each outflow was similar to LRM, total efflux was comparable to estimates from Ross et al. (2018). Watershed-scale $\mathrm{CO}_{2}$ flux discussed by Torres et al. (2014) are smaller by unit area, but produce larger total flux than sources such as MTR/VF areas and mines like LRM (Figure 46).

Figure 46 illustrates the impact of scaling when considering spatial $\mathrm{CO}_{2}$ efflux to the atmosphere, an important consideration for global carbon cycle models. Underground coal mines are difficult to constrain due to their variety of outflow chemistry (Cravotta et al., 1999; Younger et al., 2002; Cravotta, 2008), variable discharge rates in above-drainage mines (Mack et al., 2015; Burrows et al., 2015), and number of outflows, both sampled and unsampled.

Extrapolating the data from LRM to the entire Dawson No. 3 mine system shows $\mathrm{CO}_{2}$ efflux per unit area from underground coal mines is comparable to the exceptionally high weathering rates of geologic carbon studied in MTR/VF landscapes (Ross et al., 2018). Especially considering 


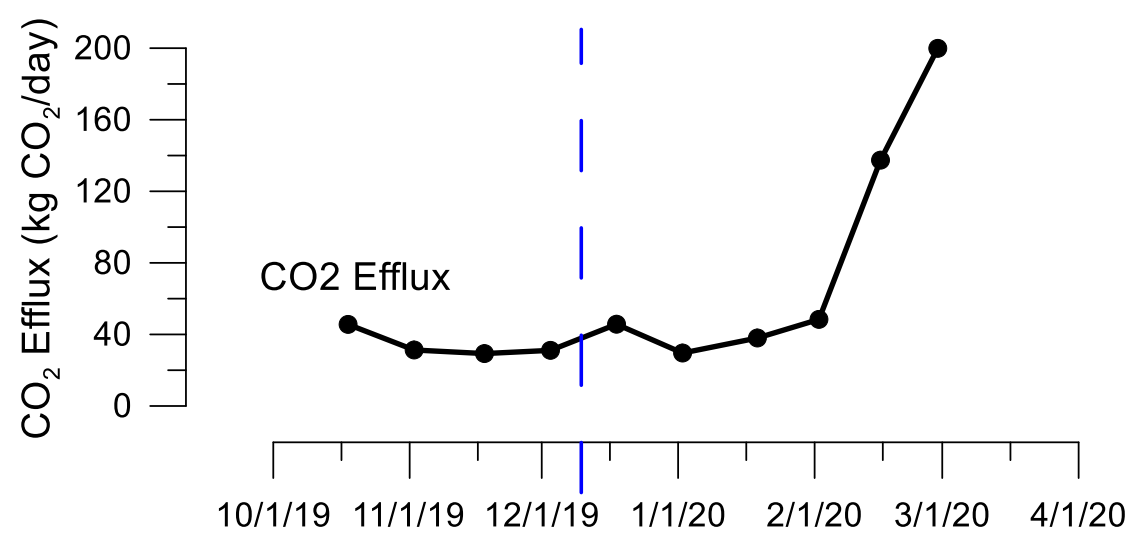

Figure 43: Temporal variability of CO2 efflux between LRM-000 to LRM-172 during the study period. Vertical dashed line indicates division between diffuse recharge dominated (left) and direct recharge dominated (right) periods. 


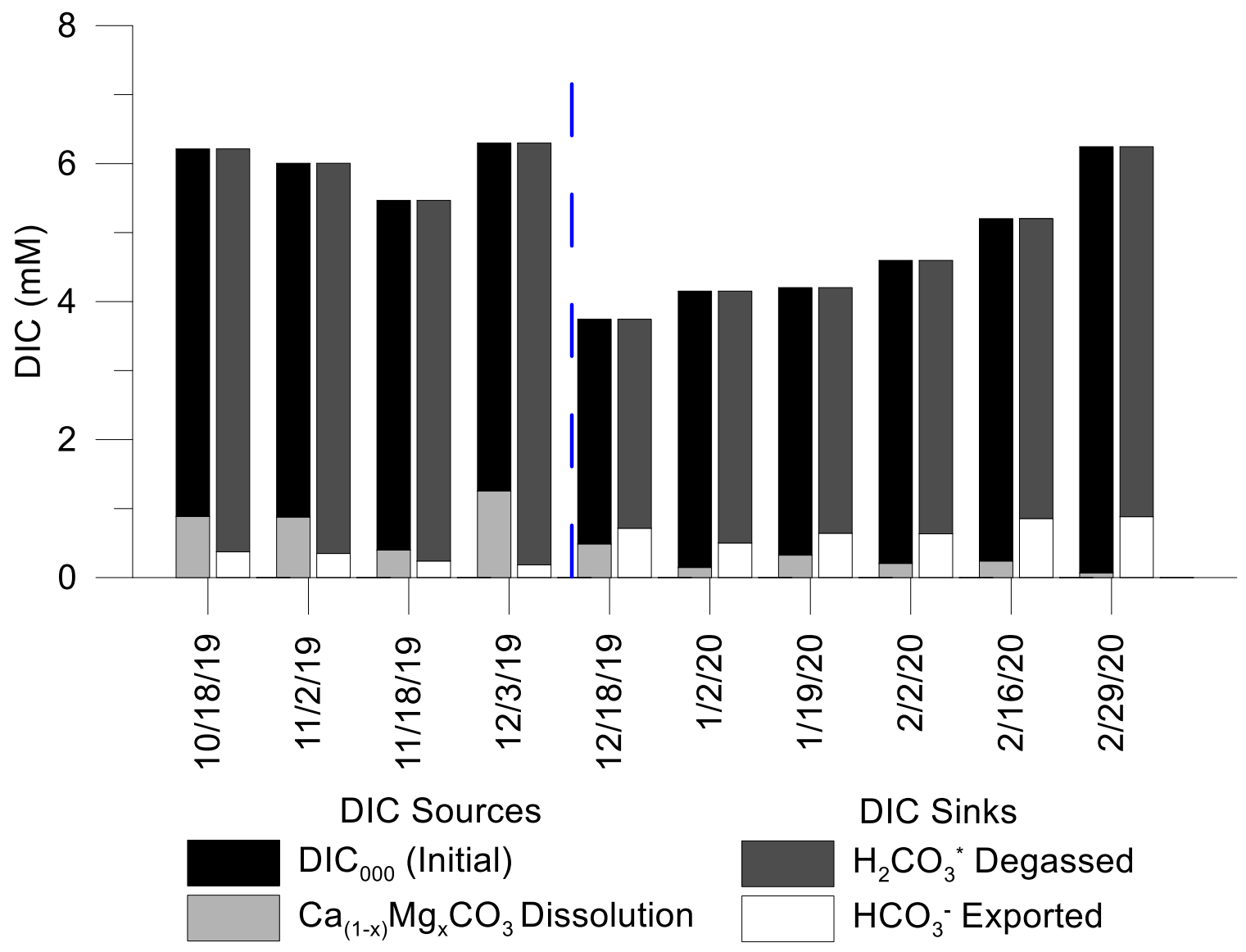

Figure 44: Temporal variation of DIC sources and sinks throughout the study period. 


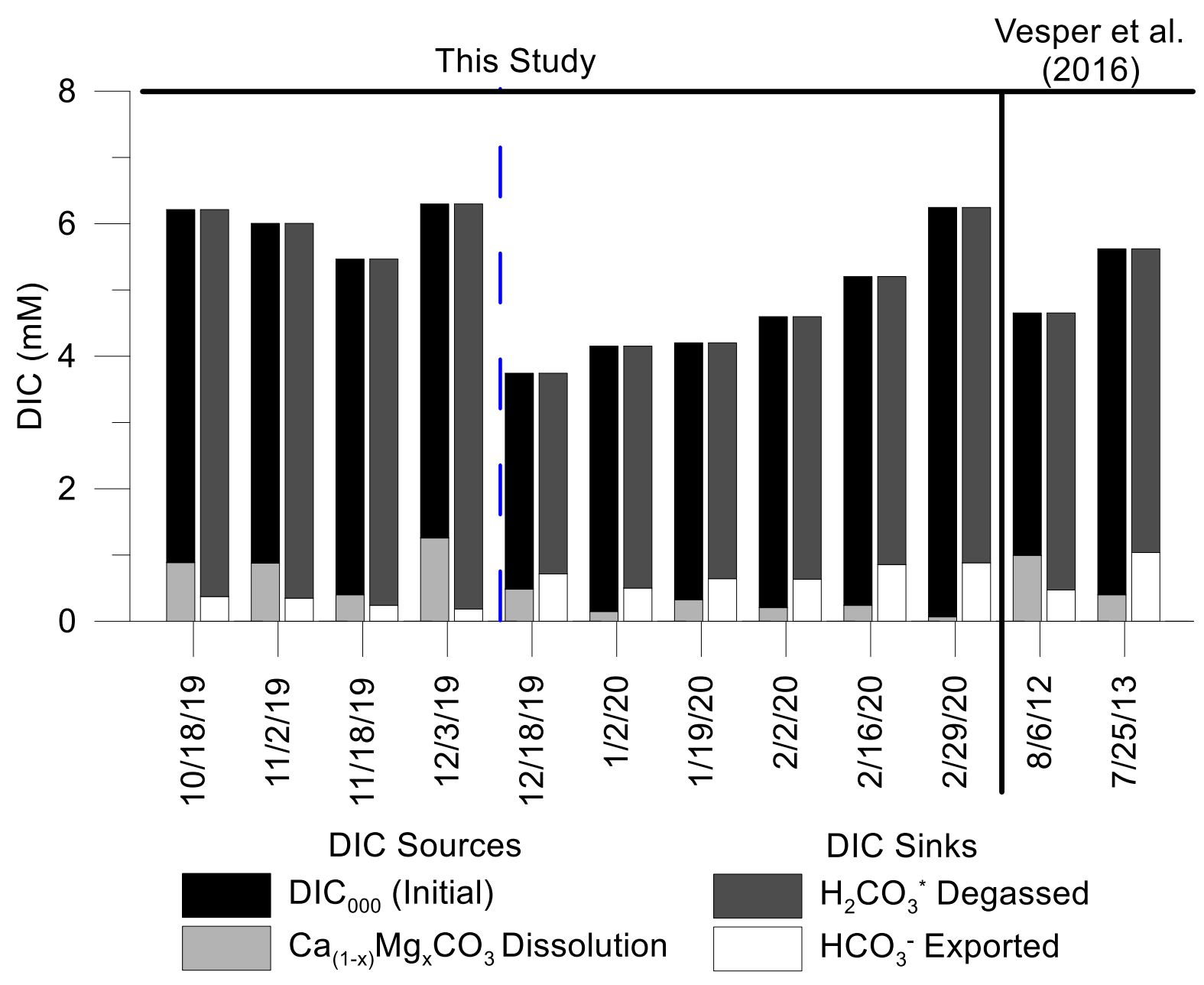

Figure 45: DIC sources and sinks at LRM compared to Vesper et al. (2016). 
efflux at LRM was lower than efflux from CMD sites throughout Pennsylvania (Vesper et al., 2016). It is also important to understand the assumptions inherent in estimating $\mathrm{CO}_{2}$ flux across a broad spatial area. To extrapolate flux from LRM to the entire Dawson No. 3 mine system, each outflow was assumed to have similar $\mathrm{CO}_{2}$ efflux to LRM. Each outflow from the Dawson No. 3 mine is an above-drainage outflow with similar lithology, so this assumption seems reasonable. Care should be exercised when analyzing and accepting the assumptions used in broader $\mathrm{CO}_{2}$ efflux studies, particularly in the absence of directly measured $\mathrm{CO}_{2}$ and DIC data. 


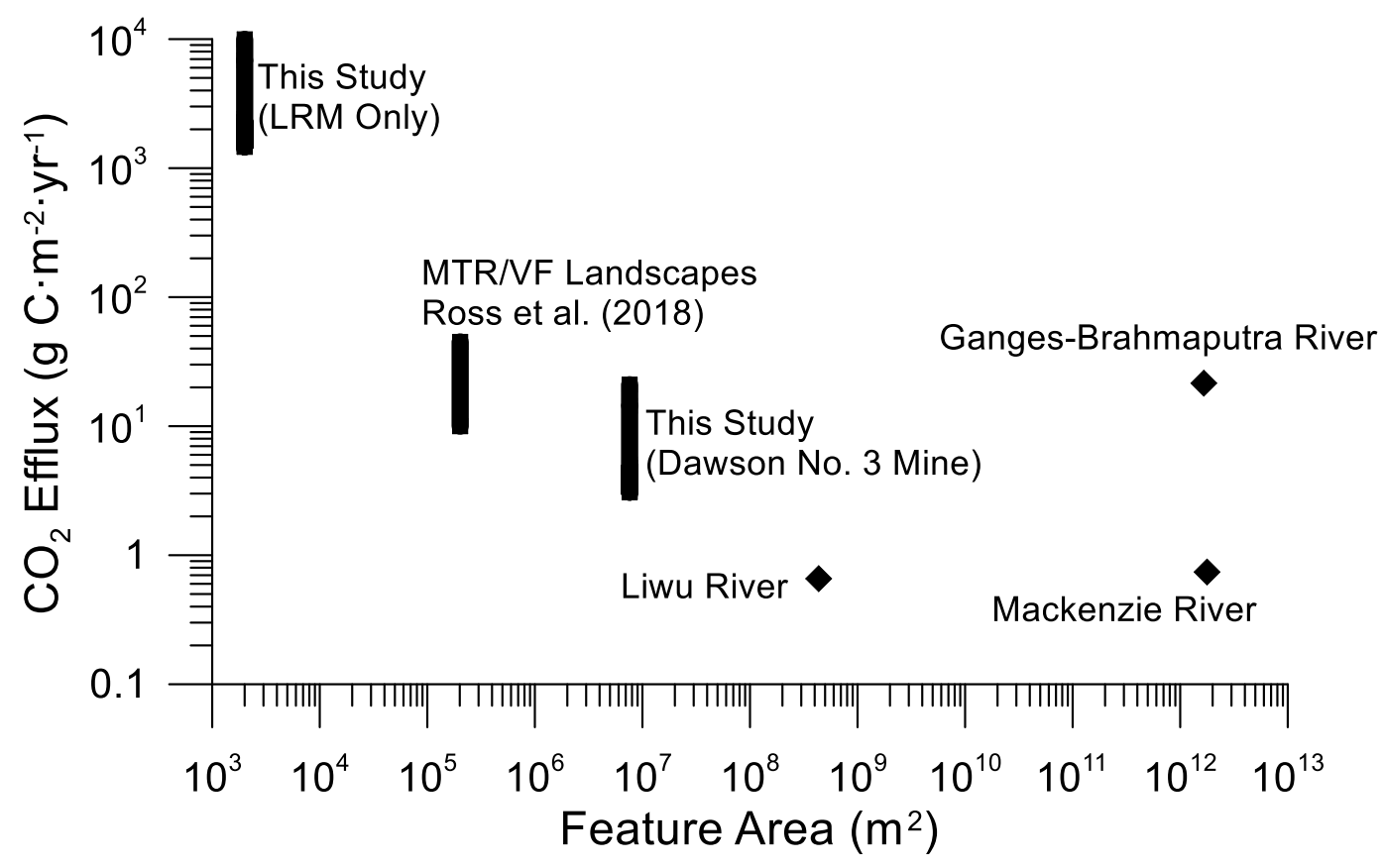

Figure 46: $\mathrm{CO}_{2}$ efflux directly to the atmosphere by unit area compared to other similar studies. Feature area refers to the size of the feature studied (i.e. mine size, watershed size). MTR/VF = mountain top removal/valley fill mine practices. Range for LRM only accounts for $\mathrm{CO}_{2}$ flux from the LRM treatment flowpath. The area used for the LRM only range only includes the area of the limestone lined channel and the altered natural wetland, similar to the methods of Vesper et al. (2016). Range for Dawson No. 3 mine assumes flux at LRM is the same as flux at other CMD outflows draining the Dawson No. 3 mine ( 8 total outflows, total area $\left.7.6 \mathrm{~km}^{2}\right)$. MTR/VF flux from Ross et al. (2018), feature area for MTR/VF flux plotted as 50 acres, the maximum permitted size of valley fills in West Virginia (WVDEP, 2017). Diamond symbols are river basin fluxes from Torres et al. (2014). 


\subsection{Summary and Conclusions}

Though this study is site specific, it provides a detailed look at the influence of recharge on geochemical process acting in the abandoned coal mine through temporal sampling at LRM-000 and LRM-SHS. The study also provides insight into geochemical processes taking place in the passive treatment system through consistent spatial sampling. Conclusions regarding rechargerelated geochemical changes in the abandoned mine workings are as follows:

- Direct recharge entering the mine through LRM-SHS introduces aerated, higher $\mathrm{pH}$, lower SC surface water into the mine workings at variable rates;

- More direct recharge causes $\mathrm{pH}$ to increase in the mine, resulting in sequestration of $\mathrm{Fe}$, $\mathrm{Al}$, and $\mathrm{Mn}$ in the mine, possibly as secondary mineral precipitates;

- Total YREE concentration at LRM-000 showed significant ( $p>0.05$ ) positive correlation to $\mathrm{Fe}, \mathrm{Al}$, and $\mathrm{Mn}$, and significant negative correlation to $\mathrm{pH}$ and discharge for all sample events, though YREE loading remained relatively consistent;

- When diffuse recharge is dominant, LRM-000 has a lower SI $\mathrm{SIalcite}_{\text {, }}$ resulting in rapid dissolution of limestone in the treatment channel; and,

- LRM-000 can be either net-acidic or net-alkaline depending on the dominant type of recharge.

Conclusions regarding geochemical changes along the treatment system flowpath are as follows:

- During both recharge regimes, $\mathrm{pH}$ and $\mathrm{DO}$ increase, and $\mathrm{Fe}, \mathrm{Al}$, and $\mathrm{Mn}$ are removed along the treatment system flowpath;

- Lower CMD constituent concentrations during direct recharge dominated periods propagate throughout the treatment system, resulting in lower average concentrations at each sampling location;

- YREE are removed along the flowpath by sorption to oxide minerals and oxidation;

- HREE are preferentially removed compared to LREE;

- Ce is removed early in the flowpath, especially when direct recharge is dominant (higher $\mathrm{pH}$, more oxygenated recharge);

- On average, $89 \%$ of DIC at LRM is degassed directly to the atmosphere as $\mathrm{CO}_{2}$, totaling an estimated 23.2 metric tons $\mathrm{CO}_{2} /$ year; and,

- Abandoned underground coal mines may have comparable $\mathrm{CO}_{2}$ efflux per unit area as mountain top removal/valley fill coal mine operations.

Observations from this study show how important recharge and mine hydrogeology is to evaluating chemical trends from above-drainage CMD outflows. Direct recharge, a function of seasonal precipitation and evaporation patterns, has been shown to increase outflow $\mathrm{pH}$, increase discharge, reduce the concentration of hydrolysable metals discharged from the mine, and increase the total $\mathrm{CO}_{2}$ degassed from the mine system. Understanding the influences of mine hydrogeology has implications for designing CMD treatment systems, interpreting routine sampling data, characterizing CMD sites for YREE removal, and extrapolating $\mathrm{CO}_{2}$ and DIC flux from abandoned mines for global carbon balance considerations. 


\subsection{Limitations}

\section{$\underline{\text { Discharge }}$}

Conditions at the site had made reproducible discharge measurements difficult for prior researchers. Though the method of discharge measurement used for this study isn't ideal (see Section 4.3.3), the author believes it is the most reproducible and feasible option, given time and budget constraints. It is likely some underflow is missed by the flume structure, particularly given the coarse limestone gravel in the outflow channel (Figure 8). Using a bucket and stopwatch to measure discharge as water crests over aeration cascades resulted in poor reproducibility in measurements because the cascades had multiple flows which needed captured. Continuous injection and slug salt traces were attempted for point discharge measurements, but a very high conductivity solution was needed to create the proper conductivity response downstream. The concentration required for a consistent, reproducible response with minimal error required the solution to be oversaturated with salt.

\section{Hyporheic Exchange}

Hyporheic exchange could influence both the chemistry of the mine outflow and the total discharge along the flowpath. The methods used in this study do not quantify hyporheic exchange or its influence on the measured chemistry or discharge. Further investigations of hyporheic exchange and its impact would be useful in quantifying metal removal and DIC flux at LRM, particularly in the altered natural wetland.

\section{$\underline{\text { DIC Sources and Sinks }}$}

The mass balanced equation used for calculating sources and sinks of DIC at LRM does not include all possible sources and sinks. Notably, cellular respiration (Reaction 10) was not included at a source of DIC and photosynthesis (Reaction 11) was not included as a sink of DIC.

$$
\begin{array}{ll}
\mathrm{C}_{6} \mathrm{H}_{12} \mathrm{O}_{6}+6 \mathrm{O}_{2} \rightarrow 6 \mathrm{CO}_{2}+6 \mathrm{H}_{2} \mathrm{O}+\text { Heat } & \text { Reaction } 10 \\
\text { Solar Energy }+6 \mathrm{CO}_{2}+6 \mathrm{H}_{2} \mathrm{O} \rightarrow \mathrm{C}_{6} \mathrm{H}_{12} \mathrm{O}_{6}+6 \mathrm{O}_{2} & \text { Reaction } 11
\end{array}
$$

Previous work at LRM suggests that biological activity can be a significant factor in seasonal and diel cycling of DIC (Riddell, 2015). Because sampling occurred between October 2019 and March 2020, biological effects throughout the sampling period should be minimalized by low temperatures and little/no growth of plant life. 


\subsection{Future Work}

\section{Detailed Mine Hydrogeology}

Features like LRM-SHS are common in mined areas from subsidence, collapses, and abandoned airshafts. Sampling throughout this project has shown they can alter CMD outflow chemistry through the addition of rapid, oxygenated, higher $\mathrm{pH}$ recharge. Knowing the location of these types of features would allow for a more complete understanding of their influence on outflow chemistry. High resolution light detection and ranging (LiDAR) elevation data would allow remote mapping of direct recharge features over large areas. Direct recharge features like LRMSHS should be identifiable across wide areas using methodologies similar to those used to identify sinkholes (Zhu et al., 2014; Wu et al., 2016). Locations of direct recharge features and continuous discharge data at CMD outflows draining the mine, could provide a more complete understanding of the mine hydrogeology and water budget.

Tracing of the LRM flowsystem from LRM-SHS to the various CMD outflows draining the mine would also be beneficial to determine travel time and determine where recharge from LRM-SHS is dominantly routed. If additional direct recharge features were also located, tracing each feature would provide more detailed insight into the mine hydrogeology and flowpaths.

\section{Temporary Metal Storage}

Analyses showed apparent sequestration of hydrolysable metals in the mine workings while direct recharge was dominant. It is likely metals are stored in metastable secondary mineral forms sensitive to changes in $\mathrm{pH}$, including but not limited to ferrihydrite, schwertmannite, goethite, $\mathrm{Fe}(\mathrm{OH})_{3}$, and $\mathrm{Al}(\mathrm{OH})_{3}$. It is currently unknown how temporarily stored metals contribute to CMD outflow longevity. With additional sampling and analysis of precipitates near the mine outflow, the temporary storage (and subsequent release) of metals in the mine workings could be estimated and modeled in the future. This could have impacts in how updip mines receiving direct recharge would be remediated, especially when compared to the dominant recharge type.

\section{Continuous $\mathrm{CO}_{2}$ Measurements and Spatial Efflux Estimates}

To fully understand the influence of seasonality and recharge on $\mathrm{CO}_{2}$ flux from mine sites like LRM, continuous $\mathrm{CO}_{2}$ measurements would be needed. Several sensors and systems are commercially available, though price can be a significant barrier to access. Given the interconnection between seasonality, recharge, $\mathrm{CMD}$ chemistry, and $\mathrm{CO}_{2}$ and DIC chemistry at complex systems like LRM, continuous $\mathrm{CO}_{2}$ data could provide valuable insights to a variety of biogeochemical systems and processes. Widespread direct measurement of $\mathrm{CO}_{2}$ would also help constrain the $\mathrm{CO}_{2}$ efflux per unit area of abandoned mine discharges for broader applications to carbon cycle and climate studies. 


\subsection{References}

Bau, M., 1999, Scavenging of dissolved yttrium and rare earths by precipitating iron oxyhydroxide: experimental evidence for Ce oxidation, Y-Ho fractionation, and lanthanide tetrad effect: Geochimica et Cosmochimica Acta, v. 63, p. 67-77, doi:10.1016/S0016-7037(99)00014-9.

Berglund, J.L., Toran, L., and Herman, E.K., 2019, Deducing flow path mixing by storminduced bulk chemistry and REE variations in two karst springs: with trends like these who needs anomalies? Journal of Hydrology, doi:10.1016/j.jhydrol.2019.01.050.

Burrows, J.E., Peters, S.C., and Cravotta, C.A., 2015, Temporal geochemical variations in above- and below-drainage coal mine discharge: Applied Geochemistry, v. 62, p. 84-95, doi:10.1016/j.apgeochem.2015.02.010.

Byrne, P., Reid, I., and Wood, P.J., 2013, Stormflow hydrochemistry of a river draining an abandoned metal mine: the Afon Twymyn, central Wales: Environmental Monitoring and Assessment, v. 185, p. 2817-2832, doi:10.1007/s10661-012-2751-5.

Cardwell, D.H., Erwin, R.B., and Woodward, H.P., 1968, Geologic map of West Virginia: WVGES.

Commercial Coal and Coke Company, 1936, Northeastern portion of the coal lands leased from Commercial Coal and Coke Company: Mine Map.

Cravotta, C.A., 2008, Dissolved metals and associated constituents in abandoned coal-mine discharges, Pennsylvania, USA. Part 1: Constituent quantities and correlations: Applied Geochemistry, v. 23, p. 166-202, doi:10.1016/j.apgeochem.2007.10.011.

Cravotta, C.A., Brady, K.B.C., Rose, A.W., and Douds, J.B., 1999, Frequency distribution of the $\mathrm{pH}$ of coal-mine drainage in Pennsylvania: U.S. Geological Survey Toxic Substances Hydrology Program US Geol Survey Open-File Rep US Geol Survey Open-File Rep 96619, 13 p., https://www.researchgate.net/profile/Charles_Cravotta/publication/229000524_Frequenc y_distribution_of_the_pH_of_coalmine_drainage_in_Pennsylvania/links/0deec5361631bf29f9000000.pdf.

Demchak, J., Skousen, J., and McDonald, L.M., 2004, Longevity of acid discharges from underground mines located above the regional water table: Journal of Environment Quality, v. 33, p. 656-668.

DOE, 2011, Department of Energy, Critical Materials Strategy (2010): Department of Energy (DOE).

Donovan, J.J., Leavitt, B.R., and Werner, E., 2003, Long-term changes in water chemistry as a result of mine flooding in closed mines of the Pittsburgh coal basin, USA, in 6th ICARD: Sixth International Conference Acid Rock Drainage : Application and Sustainability of Technologies : Proceedings 3/2003, AusIMM, p. 7, http://hrc.nrcce.wvu.edu/final/DonovanDD.PDF. 
Donovan, J.J., and Perry, E.F., 2019, Mine flooding history of a regional below-drainage coalfield dominated by barrier leakage (1970-2014): Geofluids, v. 2019, p. 1-16, doi: $10.1155 / 2019 / 5703108$.

Dzombak, D.A., and Morel, F.M.M., 1990, Surface complexation modeling: hydrous ferric oxide: New York, Wiley, 393 p.

Fox, J.F., and Campbell, J.E., 2010, Terrestrial carbon disturbance from mountaintop mining increases lifecycle emissions for clean coal: Environmental Science \& Technology, v. 44, p. 2144-2149, doi:10.1021/es903301j.

Gammons, C.H., Duaime, T.E., Parker, S.R., Poulson, S.R., and Kennelly, P., 2010, Geochemistry and stable isotope investigation of acid mine drainage associated with abandoned coal mines in central Montana, USA: Chemical Geology, v. 269, p. 100-112, doi:10.1016/j.chemgeo.2009.05.026.

Gammons, C.H., Shope, C.L., and Duaime, T.E., 2005, A $24 \mathrm{~h}$ investigation of the hydrogeochemistry of baseflow and stormwater in an urban area impacted by mining: Butte, Montana: Hydrological Processes, v. 19, p. 2737-2753, doi:10.1002/hyp.5783.

Gill, L.W., Babechuk, M.G., Kamber, B.S., McCormack, T., and Murphy, C., 2018, Use of trace and rare earth elements to quantify autogenic and allogenic inputs within a lowland karst network: Applied Geochemistry, v. 90, p. 101-114, doi:10.1016/j.apgeochem.2018.01.001.

Gromet, L.P., Haskin, L.A., Korotev, R.L., and Dymek, R.F., 1984, The "North American shale composite": Its compilation, major and trace element characteristics: Geochimica et Cosmochimica Acta, v. 48, p. 2469-2482, doi:10.1016/0016-7037(84)90298-9.

Guardians of the West Fork Watershed, 2003, Watershed based plan for the implementation of the Lambert Run TMDL:, 13 p.

Gustaffson, J.P., 2018, Visual MINTEQ ver. 3.1: Visual MINTEQ, https://vminteq.lwr.kth.se/ (accessed May 2020).

Hedin, B.C., Capo, R.C., Stewart, B.W., Hedin, R.S., Lopano, C.L., and Stuckman, M.Y., 2019, The evaluation of critical rare earth element (REE) enriched treatment solids from coal mine drainage passive treatment systems: International Journal of Coal Geology, v. 208, p. 54-64, doi:10.1016/j.coal.2019.04.007.

Johannesson, K.H., Stetzenbach, K.J., Hodge, V.F., and Berry Lyons, W., 1996, Rare earth element complexation behavior in circumneutral $\mathrm{pH}$ groundwaters: Assessing the role of carbonate and phosphate ions: Earth and Planetary Science Letters, v. 139, p. 305-319, doi:10.1016/0012-821X(96)00016-7.

Kim, J., and Kim, S., 2004, Seasonal factors controlling mineral precipitation in the acid mine drainage at Donghae coal mine, Korea: Science of The Total Environment, v. 325, p. 181-191, doi:10.1016/j.scitotenv.2003.10.038. 
Kirby, C.S., and Cravotta, C.A., 2005, Net alkalinity and net acidity 1: Theoretical considerations: Applied Geochemistry, v. 20, p. 1920-1940, doi:10.1016/j.apgeochem.2005.07.002.

Lawrence, M.G., Greig, A., Collerson, K.D., and Kamber, B.S., 2006, Rare earth element and yttrium variability in south east Queensland waterways: Aquatic Geochemistry, v. 12, p. 39-72, doi:10.1007/s10498-005-4471-8.

Lawrence, M.G., and Kamber, B.S., 2006, The behaviour of the rare earth elements during estuarine mixing - revisited: Marine Chemistry, v. 100, p. 147-161, doi:10.1016/j.marchem.2005.11.007.

Light, D.D.M., and Donovan, J.J., 2015, Mine-water flow between contiguous flooded underground coal mines with hydraulically compromised barriers: Environmental \& Engineering Geoscience, v. 21, p. 147-164, doi:10.2113/gseegeosci.21.2.147.

Liu, H., Pourret, O., Guo, H., and Bonhoure, J., 2017, Rare earth elements sorption to iron oxyhydroxide: Model development and application to groundwater: Applied Geochemistry, v. 87, p. 158-166, doi:10.1016/j.apgeochem.2017.10.020.

Lloyd, J., and Taylor, J.A., 1994, On the temperature dependence of soil respiration: Functional Ecology, v. 8, p. 315, doi:10.2307/2389824.

Mack, B., Skousen, J., and McDonald, L.M., 2015, Effect of flow rate on acidity concentration from above-drainage underground mines: Mine Water and the Environment, v. 34, p. 50 58, doi:10.1007/s10230-014-0278-4.

Morris, A.J., Donovan, J.J., and Thies, J.E., 2008, Reconnaissance spatial analysis of the hydrogeology of closed underground coal mines: Environmental Geosciences, v. 15, p. 183-197, doi:10.1306/eg.05200808001.

Mountjoy, B.D., 2018, Hydrogeology and water management in the Arkwright underground coal mine, Pittsburgh seam, northern West Virginia [M.S.]: West Virginia University, 74 p., https://search.proquest.com/pqdtglobal/docview/2102539691/abstract/6DC0A5DCF3D14 0E3PQ/6 (accessed December 2018).

Nimick, D.A., Gammons, C.H., Cleasby, T.E., Madison, J.P., Skaar, D., and Brick, C.M., 2003, Diel cycles in dissolved metal concentrations in streams: Occurrence and possible causes: Water Resources Research, v. 39, doi:10.1029/2002WR001571.

NOAA, 2020, National Weather Service Annual Climate Report, Clarksburg WV: weather.gov, https://w2.weather.gov/climate/index.php?wfo=rlx (accessed April 2020).

Nordstrom, D.K., 2009, Acid rock drainage and climate change: Journal of Geochemical Exploration, v. 100, p. 97-104, doi:10.1016/j.gexplo.2008.08.002.

Nordstrom, D.K., 1982, Aqueous pyrite oxidation and the consequent formation of secondary iron minerals, in Acid Sulfate Weathering, Soil Science Society of America, p. 37-56. 
Parkhurst, D.L., and Appelo, C.A.J., 2013, U.S. Geological Survey Techniques and Methods book 6, in Description of input and examples for PHREEQC version 3-A computer program for speciation, batch-reaction, one-dimensional transport, and inverse geochemical calculations, v. A43, p. 497, http://pubs.usgs.gov/tm/06/a43/.

Plummer, L.N., and Busenberg, E., 1982, The solubilities of calcite, aragonite and vaterite in $\mathrm{CO}_{2}-\mathrm{H}_{2} \mathrm{O}$ solutions between 0 and $90^{\circ} \mathrm{C}$, and an evaluation of the aqueous model for the system $\mathrm{CaCO}_{3}-\mathrm{CO}_{2}-\mathrm{H}_{2} \mathrm{O}$ : v. 46, p. 1011-1040, doi:10.1016/0016-7037(82)90056-4.

Raymond, P.A., and Oh, N.-H., 2009, Long term changes of chemical weathering products in rivers heavily impacted from acid mine drainage: Insights on the impact of coal mining on regional and global carbon and sulfur budgets: Earth and Planetary Science Letters, v. 284, p. 50-56, doi:10.1016/j.epsl.2009.04.006.

Riddell, J.L., 2015, Comparing diel cycles of dissolved inorganic carbon to diel cycles of Fe and Mn at a coal mine drainage site in Harrison Co., WV [M.S.]: West Virginia University, $137 \mathrm{p}$.

https://search.proquest.com/pqdtglobal/docview/1682044744/abstract/1DB8DC15213F49 E6PQ/6 (accessed October 2018).

Ross, M.R.V., Nippgen, F., Hassett, B.A., McGlynn, B.L., and Bernhardt, E.S., 2018, Pyrite oxidation drives exceptionally high weathering rates and geologic $\mathrm{CO}_{2}$ release in mountaintop-mined landscapes.: Global Biogeochemical Cycles, doi:10.1029/2017GB005798.

Rozelle, P.L., Khadilkar, A.B., Pulati, N., Soundarrajan, N., Klima, M.S., Mosser, M.M., Miller, C.E., and Pisupati, S.V., 2016, A study on removal of rare earth elements from U.S. coal byproducts by ion exchange: Metallurgical and Materials Transactions, v. 3, p. 6-17, doi:10.1007/s40553-015-0064-7.

Sahu, P., López, D.L., and Stoertz, M.W., 2009, Using time series analysis of coal mine hydrographs to estimate mine storage, retention time, and mine-pool interconnection: Mine Water and the Environment, v. 28, p. 194-205, doi:10.1007/s10230-009-0076-6.

Shuster, E.T., and White, W.B., 1971, Seasonal fluctuations in the chemistry of lime-stone springs: A possible means for characterizing carbonate aquifers: Journal of Hydrology, v. 14, p. 93-128, doi:10.1016/0022-1694(71)90001-1.

Skousen, J.G., Zipper, C.E., Rose, A., Ziemkiewicz, P.F., Nairn, R., McDonald, L.M., and Kleinmann, R.L., 2017, Review of passive systems for acid mine drainage treatment: Mine Water and the Environment, v. 36, p. 133-153, doi:10.1007/s10230-016-0417-1.

Smilley, M.J., 2007, Determination of diel chemical cycle presence within abandoned coal mine drainage streams in Harrison County, West Virginia [M.S.]: West Virginia University, 132 p., https://search.proquest.com/pqdtglobal/docview/304798869/abstract/1DB8DC15213F49 E6PQ/2 (accessed October 2018). 
Stewart, B.W., Capo, R.C., Hedin, B.C., and Hedin, R.S., 2017, Rare earth element resources in coal mine drainage and treatment precipitates in the Appalachian Basin, USA: International Journal of Coal Geology, v. 169, p. 28-39, doi:10.1016/j.coal.2016.11.002.

Stumm, W., and Morgan, J.J., 1996, Aquatic Chemistry: Chemical Equilibria and Rates in Natural Waters: Wiley-Interscience.

Thornthwaite, C.W., 1948, An approach toward a rational classification of climate: Geographical Review, v. 38, p. 55-94.

Torres, M.A., West, A.J., and Li, G., 2014, Sulphide oxidation and carbonate dissolution as a source of $\mathrm{CO}_{2}$ over geological timescales: Nature, v. 507, p. 346-349, doi:10.1038/nature13030.

Troester, J.W., and White, W.B., 1984, Seasonal fluctuations in the carbon dioxide partial pressure in a cave atmosphere: Water Resources Research, v. 20, p. 153-156, doi:10.1029/WR020i001p00153.

Turnipseed, D.P., and Sauer, V.B., 2010, Discharge measurements at gaging stations, in U.S. Geological Survey Techniques and Methods 3-A8, v. 3, p. 106, https://pubs.usgs.gov/tm/tm3-a8/tm3a8.pdf.

U.S. Environmental Protection Agency, 2002, Metals and pH TMDLs for the West Fork River watershed, West Virginia:, 81 p., https://dep.wv.gov/WWE/watershed/TMDL/grpe/Documents/West\%20Fork/3024_westf ork_tmdl.pdf (accessed March 2019).

Vesper, D.J., and Edenborn, H.M., 2012, Determination of free $\mathrm{CO}_{2}$ in emergent groundwaters using a commercial beverage carbonation meter: Journal of Hydrology, v. 438-439, p. 148-155, doi:10.1016/j.jhydrol.2012.03.015.

Vesper, D.J., Edenborn, H.M., Billings, A.A., and Moore, J.E., 2015, A field-based method for determination of dissolved inorganic carbon in water based on $\mathrm{CO}_{2}$ and carbonate equilibria: Water, Air, \& Soil Pollution, v. 226, doi:10.1007/s11270-015-2348-z.

Vesper, D.J., Moore, J.E., and Adams, J.P., 2016, Inorganic carbon dynamics and $\mathrm{CO}_{2}$ flux associated with coal-mine drainage sites in Blythedale PA and Lambert WV, USA: Environmental Earth Sciences, v. 75, doi:10.1007/s12665-015-5191-z.

Vesper, D.J., and Smilley, M.J., 2010, Attenuation and diel cycling of coal-mine drainage constituents in a passive treatment wetland: A case study from Lambert Run, West Virginia, USA: Applied Geochemistry, v. 25, doi:doi:10.1016/j.apgeochem.2010.02.010.

Wallrich, I.L.R., Stewart, B.W., Capo, R.C., Hedin, B.C., and Phan, T.T., 2020, Neodymium isotopes track sources of rare earth elements in acidic mine waters: Geochimica et Cosmochimica Acta, v. 269, p. 465-483, doi:10.1016/j.gca.2019.10.044. 
Weather Underground, 2020, Weather Underground: North Central West Virginia Airport Station, https://www.wunderground.com/history/monthly/us/wv/bridgeport/KCKB/date/2019-11 (accessed March 2020).

White, W.B., 1988, Geomorphology and Hydrology of Karst Terrains: New York, Oxford University Press, 464 p.

White, W.B., 1997, Thermodynamic equilibrium, kinetics, activation barriers, and reaction mechanisms for chemical reactions in Karst Terrains: Environmental Geology, v. 30, p. 46-58, doi:10.1007/s002540050131.

Wu, Q., Deng, C., and Chen, Z., 2016, Automated delineation of karst sinkholes from LiDARderived digital elevation models: Geomorphology, v. 266, p. 1-10, doi:10.1016/j.geomorph.2016.05.006.

WVDEP, 2017, Permitting Handbook:, https://dep.wv.gov/dmr/handbooks/Documents/09-252018\%20Permit\%20Handbook.pdf (accessed May 2020).

WVDEP, 2016, West Virginia integrated water quality monitoring and assessment report:, 349

p., https://dep.wv.gov/WWE/watershed/IR/Documents/IR_2016_Documents/USEPA_Appro ved_IR_303d_Complete\%20Document.pdf (accessed March 2019).

WVGES, 2013, Pittsburgh Coal: Coal Bed Mapping Project, http://www.wvgs.wvnet.edu/GIS/CBMP/Pittsburgh.html (accessed March 2019).

WVGES, 2019, West Virginia Mine Information Database System: West Virginia Mine Information Database System, https://www.wvgs.wvnet.edu/www/mids/main.php (accessed March 2019).

Younger, P.L., Banwart, S.A., and Hedin, R.S., 2002, Mine water: Hydrology, Pollution, Remediation: Dordrecht, Kluwer Acad. Publ, Environmental pollution 5, 442 p.

Zhu, J., Taylor, T., Currens, J., and Crawford, M., 2014, Improved karst sinkhole mapping in Kentucky using LiDAR techniques: A pilot study in Floyds Fork watershed: Journal of Cave and Karst Studies, v. 76, p. 207-216, doi:10.4311/2013ES0135. 
Appendix A: Data Tables 
Table A-1: Meter, ICP-MS, IC Data

\begin{tabular}{|c|c|c|c|c|c|c|c|c|c|c|c|c|}
\hline Tracking ID & Date & Time & $\begin{array}{r}\text { temp } \\
\mathrm{C}\end{array}$ & $\mathbf{p H}$ & $\begin{array}{r}\mathrm{SC} \\
\mathrm{mS} / \mathrm{cm}\end{array}$ & $\begin{array}{r}\mathrm{DO} \\
\mathrm{mg} / \mathrm{L}\end{array}$ & $\begin{array}{r}\text { DO } \\
\text { \% } \text { sat. }\end{array}$ & $\begin{array}{r}\mathrm{Cl} \\
\mathrm{mg} / \mathrm{L}\end{array}$ & $\begin{array}{c}\mathrm{SO4} \\
\mathrm{mg} / \mathrm{L}\end{array}$ & $\begin{array}{r}\mathrm{Na} \\
\mathrm{ug} / \mathrm{L}\end{array}$ & $\begin{array}{r}\mathrm{Li} \\
\mathrm{ug} / \mathrm{L}\end{array}$ & $\begin{array}{r}\text { Be } \\
\text { ug/L }\end{array}$ \\
\hline MDL & mm/dd/yyyy & $24 \mathrm{hr}$ & -- & -- & -- & -- & -- & 0.12 & 0.099 & 5 & 1 & 0.1 \\
\hline LRM050-s19-1018 & $10 / 18 / 2019$ & $13: 55$ & 12.8 & 5.89 & 1.002 & 8.71 & 85.4 & 1.934 & 569.8 & 24100 & 44 & $<\mathrm{MDL}$ \\
\hline LRM172-s19-1018 & $10 / 18 / 2019$ & $13: 15$ & 12.3 & 7.12 & 1.002 & 10 & 96.9 & 1.71 & 564.51 & 24300 & 44 & $<\mathrm{MDL}$ \\
\hline LRM000-s19-1024 & $10 / 24 / 2019$ & $16: 20$ & 12.8 & 3.94 & 1.089 & 0.24 & 2.4 & & & & & \\
\hline LRM172-s19-1024 & $10 / 24 / 2019$ & $14: 50$ & 13.9 & 7.04 & 1.041 & 9.69 & 96.6 & & & & & \\
\hline LRM000-s19-1102 & $11 / 2 / 2019$ & $11: 55$ & 12.7 & 3.9 & 1.158 & 1.39 & 13.6 & 1.871 & 514.29 & 34800 & 41 & 0.2 \\
\hline LRM050-s19-1102 & $11 / 2 / 2019$ & $10: 30$ & 11.1 & 5.88 & 0.962 & 9.34 & 87.8 & 1.754 & 547.14 & 24100 & 43 & $<\mathrm{MDL}$ \\
\hline LRM172-s19-1102 & $11 / 2 / 2019$ & $9: 45$ & 7.2 & 7.03 & 0.978 & 11.76 & 100.6 & 1.684 & 551.48 & 23700 & 40 & $<\mathrm{MDL}$ \\
\hline LRM000-s19-1110 & $11 / 10 / 2019$ & $12: 00$ & 12.6 & 4.03 & 1.034 & 1.45 & 14.2 & & & & & \\
\hline LRM050-s19-1110 & $11 / 10 / 2019$ & $10: 55$ & 12.2 & 5.87 & 1.036 & 8.88 & 85.8 & & & & & \\
\hline LRM000-s19-1203 & $12 / 3 / 2019$ & $15: 05$ & 12.5 & 3.93 & 1.042 & 1.38 & 13.6 & 2.158 & 524.5 & 36600 & 34 & 0.3 \\
\hline LRM050-s19-1203 & $12 / 3 / 2019$ & $13: 55$ & 11 & 5.87 & 1.06 & 9.28 & 88.1 & 1.257 & 552.45 & 23000 & 34 & 0.1 \\
\hline LRM172-s19-1203 & $12 / 3 / 2019$ & $13: 15$ & 8.3 & 7.02 & 1.024 & 10.89 & 96.6 & 2.025 & 517.79 & 21900 & 31 & $<\mathrm{MDL}$ \\
\hline LRM000-s19-1211 & $12 / 11 / 2019$ & $15: 15$ & 12.3 & 4.34 & 1.008 & 0.19 & 1.8 & & & & & \\
\hline LRM050-s19-1211 & $12 / 11 / 2019$ & $13: 15$ & 10.3 & 6.05 & 1.009 & 9.9 & 90.6 & & & & & \\
\hline LRM172-s19-1211 & $12 / 11 / 2019$ & $12: 50$ & 7.2 & 7.06 & 0.939 & 11.56 & 98.2 & & & & & \\
\hline LRMSHS-s19-1211 & $12 / 11 / 2019$ & $14: 05$ & 4.2 & 7.47 & 0.4809 & 11.77 & 92.7 & & & & & \\
\hline LRM000-s19-1218 & $12 / 18 / 2019$ & $16: 00$ & 10.8 & 4.45 & 0.782 & 3.85 & 37.1 & 1.731 & 411.29 & 35600 & 36 & 0.1 \\
\hline LRM050-s19-1218 & $12 / 18 / 2019$ & $14: 50$ & 10.8 & 6.36 & 0.824 & 9.66 & 90.1 & 1.056 & 384.4 & 18200 & 35 & $<\mathrm{MDL}$ \\
\hline LRM172-s19-1218 & $12 / 18 / 2019$ & $14: 15$ & 7.3 & 7.31 & 0.6824 & 10.91 & 93.8 & 1.638 & 294.31 & 13900 & 26 & $<\mathrm{MDL}$ \\
\hline LRMSHS-d19-1218 & $12 / 18 / 2019$ & $13: 30$ & 6.3 & 7.81 & 0.4347 & 11.29 & 94.9 & 1.036 & 52.067 & 13700 & 6 & $<\mathrm{MDL}$ \\
\hline
\end{tabular}

Blank cells indiate no data collected

MDL $=$ Method Detection Limit

$<\mathrm{MDL}=$ parameter not detecteble above the method detection limit 
Table A-1: Meter, ICP-MS, IC Data

\begin{tabular}{|c|c|c|c|c|c|c|c|c|c|c|c|c|}
\hline Tracking ID & Date & Time & $\begin{array}{r}\text { temp } \\
\mathrm{C}\end{array}$ & $\mathbf{p H}$ & $\begin{array}{r}\mathrm{SC} \\
\mathrm{mS} / \mathrm{cm}\end{array}$ & $\begin{array}{r}\text { DO } \\
\mathrm{mg} / \mathrm{L}\end{array}$ & $\begin{array}{r}\text { DO } \\
\% \text { sat. }\end{array}$ & $\begin{array}{r}\mathrm{Cl} \\
\mathrm{mg} / \mathrm{L}\end{array}$ & $\begin{array}{c}\mathrm{SO4} \\
\mathrm{mg} / \mathrm{L}\end{array}$ & $\begin{array}{r}\mathrm{Na} \\
\mathrm{ug} / \mathrm{L}\end{array}$ & $\begin{array}{r}\mathrm{Li} \\
\mathrm{ug} / \mathrm{L}\end{array}$ & $\begin{array}{r}\text { Be } \\
\text { ug/L }\end{array}$ \\
\hline MDL & mm/dd/yyyy & $24 \mathrm{hr}$ & -- & -- & -- & -- & -- & 0.12 & 0.099 & 5 & 1 & 0.1 \\
\hline LRM000-s20-0119 & $1 / 19 / 2020$ & $15: 55$ & 11.6 & 4.55 & 0.896 & 0.15 & 1.4 & 2.705 & 428.1 & 37200 & 33 & $<\mathrm{MDL}$ \\
\hline LRM050-s20-0119 & $1 / 19 / 2020$ & $14: 30$ & 10.9 & 6.26 & 0.86 & 9.66 & 90.7 & 1.317 & 393.37 & 19400 & 33 & $<\mathrm{MDL}$ \\
\hline LRM172-s20-0119 & $1 / 19 / 2020$ & $13: 45$ & 8.4 & 7.26 & 0.797 & 10.8 & 95.6 & 1.23 & 355.36 & 17800 & 29 & $<\mathrm{MDL}$ \\
\hline LRM050-s20-0202 & $2 / 2 / 2020$ & $13: 45$ & 11.9 & 6.35 & 0.887 & 9.63 & 94 & 1.415 & 399.14 & 19700 & 34 & $<\mathrm{MDL}$ \\
\hline LRM172-s20-0202 & $2 / 2 / 2020$ & 13:05 & 11.6 & 7.31 & 0.854 & 10.19 & 99 & 1.073 & 384.82 & 18000 & 31 & $<\mathrm{MDL}$ \\
\hline LRMSHS-s20-0202 & $2 / 2 / 2020$ & $12: 10$ & 7.4 & 8.03 & 0.6966 & 11.46 & 100.8 & 1 & 79.601 & 24500 & 11 & $<\mathrm{MDL}$ \\
\hline LRM000-s20-0216 & $2 / 16 / 2020$ & $13: 30$ & 11.8 & 5.29 & 0.926 & 0.24 & 2.4 & 1.117 & 397.81 & 22800 & 30 & $<\mathrm{MDL}$ \\
\hline LRM050-s20-0216 & $2 / 16 / 2020$ & $12: 20$ & 11.8 & 6.26 & 0.863 & 9.39 & 90 & 1.346 & 394.04 & 16000 & 31 & $<\mathrm{MDL}$ \\
\hline LRM172-s20-0229 & $2 / 29 / 2020$ & $10: 40$ & 9.8 & 7.16 & 1.102 & 10.74 & 98.2 & 1.297 & 511.92 & 20600 & 34 & $<\mathrm{MDL}$ \\
\hline LRMSHS-s20-0229 & $2 / 29 / 2020$ & $9: 55$ & 5.1 & 7.95 & 0.6724 & 12.21 & 99.6 & 1.172 & 76.559 & 22100 & 9 & $<\mathrm{MDL}$ \\
\hline LRM000-s20-0314 & $3 / 14 / 2020$ & $12: 25$ & 12.5 & 5.49 & 1.121 & 2.32 & 22.3 & & & & & \\
\hline LRM050-s20-0314 & $3 / 14 / 2020$ & $11: 40$ & 12.1 & 6.29 & 1.137 & 9.78 & 93.3 & & & & & \\
\hline LRM172-s20-0314 & $3 / 14 / 2020$ & 11:05 & 11.4 & 7.2 & 1.113 & 10.59 & 99.4 & & & & & \\
\hline LRMSHS-s20-0314 & $3 / 14 / 2020$ & $10: 30$ & 8.9 & 8.04 & 0.6449 & 11.27 & 99.9 & & & & & \\
\hline
\end{tabular}

Blank cells indiate no data collected

MDL $=$ Method Detection Limit

$<\mathrm{MDL}=$ parameter not detecteble above the method detection limit 


\begin{tabular}{|c|c|c|c|c|c|c|c|c|c|c|c|c|c|c|}
\hline Tracking ID & $\begin{array}{c}\mathrm{Mg} \\
\mathbf{u g} / \mathrm{L}\end{array}$ & $\begin{array}{r}\mathrm{Al} \\
\mathbf{u g} / \mathrm{L}\end{array}$ & $\begin{array}{r}\mathrm{Si} \\
\mathrm{ug} / \mathrm{L}\end{array}$ & $\begin{array}{r}\mathbf{K} \\
\mathbf{u g} / \mathrm{L}\end{array}$ & $\begin{array}{r}\mathrm{Ca} \\
\mathrm{ug} / \mathrm{L}\end{array}$ & $\begin{array}{r}\mathrm{Sc} \\
\mathrm{ug} / \mathrm{L}\end{array}$ & $\begin{array}{r}\mathrm{Ti} \\
\mathrm{ug} / \mathrm{L}\end{array}$ & $\begin{array}{r}\mathrm{V} \\
\mathrm{ug} / \mathrm{L}\end{array}$ & $\begin{array}{r}\mathrm{Cr} \\
\mathrm{ug} / \mathrm{L}\end{array}$ & $\begin{array}{r}\mathrm{Mn} \\
\mathrm{ug} / \mathrm{L}\end{array}$ & $\begin{array}{r}\mathrm{Fe} \\
\mathrm{ug} / \mathrm{L}\end{array}$ & $\begin{array}{r}\mathrm{Co} \\
\mathrm{ug} / \mathrm{L}\end{array}$ & $\begin{array}{r}\mathrm{Ni} \\
\mathrm{ug} / \mathrm{L}\end{array}$ & $\begin{array}{r}\mathrm{Cu} \\
\mathbf{u g} / \mathrm{L}\end{array}$ \\
\hline MDL & 2 & 2 & 200 & 30 & 700 & 1 & 0.1 & 0.1 & 0.05 & 0.1 & 10 & 0.005 & 0.3 & 0.2 \\
\hline LRM000-s19-1018 & 37500 & 1090 & 9300 & 5210 & 110000 & $<\mathrm{MDL}$ & $<\mathrm{MDL}$ & $<\mathrm{MDL}$ & $<\mathrm{MDL}$ & 3680 & 7900 & 8.48 & 25.5 & 0.5 \\
\hline LRM050-s19-1018 & 45800 & 77 & 9800 & 4960 & 134000 & $<\mathrm{MDL}$ & $<\mathrm{MDL}$ & $<\mathrm{MDL}$ & $<\mathrm{MDL}$ & 2160 & 810 & 2.89 & 24.7 & $<\mathrm{MDL}$ \\
\hline LRM172-s19-1018 & 45700 & 4 & 8900 & 4780 & 132000 & $<\mathrm{MDL}$ & $<\mathrm{MDL}$ & $<\mathrm{MDL}$ & $<\mathrm{MDL}$ & 1100 & 70 & 0.498 & 10.6 & $<\mathrm{MDL}$ \\
\hline \multicolumn{15}{|l|}{ LRM000-s19-1024 } \\
\hline \multicolumn{15}{|l|}{ LRM050-s19-1024 } \\
\hline \multicolumn{15}{|l|}{ LRM172-s19-1024 } \\
\hline LRM000-s19-1102 & 37900 & 1130 & 9600 & 5270 & 113000 & $<\mathrm{MDL}$ & $<\mathrm{MDL}$ & $<\mathrm{MDL}$ & $<\mathrm{MDL}$ & 3370 & 10200 & 7.75 & 24.6 & 0.4 \\
\hline LRM050-s19-1102 & 46100 & 126 & 10300 & 5240 & 137000 & $<\mathrm{MDL}$ & $<\mathrm{MDL}$ & $<\mathrm{MDL}$ & $<\mathrm{MDL}$ & 2170 & 600 & 3.03 & 25.5 & $<\mathrm{MDL}$ \\
\hline LRM172-s19-1102 & 45900 & 2 & 9500 & 5090 & 135000 & $<\mathrm{MDL}$ & $<\mathrm{MDL}$ & $<\mathrm{MDL}$ & $<\mathrm{MDL}$ & 1060 & 70 & 0.708 & 12.8 & $<\mathrm{MDL}$ \\
\hline \multicolumn{15}{|l|}{ LRM000-s19-1110 } \\
\hline \multicolumn{15}{|l|}{ LRM050-s19-1110 } \\
\hline \multicolumn{15}{|l|}{ LRM172-s19-1110 } \\
\hline LRM000-s19-1118 & 39100 & 1170 & 8400 & 5880 & 125000 & $<\mathrm{MDL}$ & $<\mathrm{MDL}$ & $<\mathrm{MDL}$ & $<\mathrm{MDL}$ & 3460 & 13000 & 9.64 & 26.1 & 0.5 \\
\hline LRM050-s19-1118 & 46900 & 171 & 9000 & 6100 & 121000 & $<\mathrm{MDL}$ & $<$ MDL & $<\mathrm{MDL}$ & $<$ MDL & 2160 & 1480 & 3.85 & 27.6 & $<\mathrm{MDL}$ \\
\hline LRM172-s19-1118 & 39700 & 3 & 8300 & 5370 & 110000 & $<\mathrm{MDL}$ & $<\mathrm{MDL}$ & $<\mathrm{MDL}$ & $<\mathrm{MDL}$ & 883 & 50 & 0.691 & 13.4 & $<\mathrm{MDL}$ \\
\hline LRM000-s19-1203 & 34400 & 993 & 8400 & 5520 & 91700 & $<\mathrm{MDL}$ & $<\mathrm{MDL}$ & $<\mathrm{MDL}$ & $<\mathrm{MDL}$ & 2750 & 8670 & 9.1 & 24.7 & 0.5 \\
\hline LRM050-s19-1203 & 39800 & 165 & 8800 & 6510 & 106000 & $<\mathrm{MDL}$ & $<\mathrm{MDL}$ & $<\mathrm{MDL}$ & $<\mathrm{MDL}$ & 1650 & 1910 & 3.7 & 25.5 & 0.2 \\
\hline LRM172-s19-1203 & 44100 & 4 & 7900 & 5800 & 126000 & $<\mathrm{MDL}$ & $<\mathrm{MDL}$ & $<$ MDL & $<\mathrm{MDL}$ & 939 & 60 & 0.8 & 12.5 & $<\mathrm{MDL}$ \\
\hline \multicolumn{15}{|l|}{ LRM000-s19-1211 } \\
\hline \multicolumn{15}{|l|}{ LRM050-s19-1211 } \\
\hline \multicolumn{15}{|l|}{ LRM172-s19-1211 } \\
\hline \multicolumn{15}{|l|}{ LRMSHS-s19-1211 } \\
\hline LRM000-s19-1218 & 32400 & 492 & 7100 & 4160 & 96300 & $<\mathrm{MDL}$ & $<\mathrm{MDL}$ & $<\mathrm{MDL}$ & $<\mathrm{MDL}$ & 1450 & 1330 & 3.2 & 14.3 & 0.3 \\
\hline LRM050-s19-1218 & 35300 & 36 & 7400 & 3660 & 99600 & $<\mathrm{MDL}$ & $<\mathrm{MDL}$ & $<\mathrm{MDL}$ & $<\mathrm{MDL}$ & 780 & 270 & 0.816 & 9.5 & $<\mathrm{MDL}$ \\
\hline LRM172-s19-1218 & 29700 & 7 & 5800 & 4300 & 81200 & $<\mathrm{MDL}$ & $<\mathrm{MDL}$ & $<\mathrm{MDL}$ & $<\mathrm{MDL}$ & 474 & 60 & 0.416 & 5.3 & 0.2 \\
\hline LRMSHS-d19-1218 & 21700 & 6 & 3100 & 2130 & 46200 & $<\mathrm{MDL}$ & $<\mathrm{MDL}$ & $<\mathrm{MDL}$ & $<\mathrm{MDL}$ & 3.2 & 10 & 0.023 & $<\mathrm{MDL}$ & 0.5 \\
\hline LRMSHS-s19-1218 & 21000 & 7 & 3700 & 2030 & 55700 & $<\mathrm{MDL}$ & $<\mathrm{MDL}$ & $<\mathrm{MDL}$ & $<\mathrm{MDL}$ & 3.1 & 10 & 0.027 & $<\mathrm{MDL}$ & 0.5 \\
\hline LRM000-s20-0102 & 40400 & 496 & 7200 & 5540 & 98900 & $<\mathrm{MDL}$ & $<\mathrm{MDL}$ & $<\mathrm{MDL}$ & $<\mathrm{MDL}$ & 2880 & 750 & 5.28 & 14.9 & 0.5 \\
\hline LRM050-s20-0102 & 45200 & 30 & 7800 & 5240 & 110000 & $<\mathrm{MDL}$ & $<\mathrm{MDL}$ & $<\mathrm{MDL}$ & $<\mathrm{MDL}$ & 863 & 150 & 1.24 & 9.2 & $<\mathrm{MDL}$ \\
\hline LRM172-s20-0102 & 43400 & 3 & 7100 & 3860 & 99800 & $<\mathrm{MDL}$ & $<\mathrm{MDL}$ & $<\mathrm{MDL}$ & $<\mathrm{MDL}$ & 383 & 40 & 0.338 & 4.9 & $<\mathrm{MDL}$ \\
\hline
\end{tabular}

Blank cells indiate no data collected

MDL $=$ Method Detection Limit

$<\mathrm{MDL}=$ parameter not detecteble above the method detection limit 


\begin{tabular}{|c|c|c|c|c|c|c|c|c|c|c|c|c|c|c|}
\hline Tracking ID & $\begin{array}{r}\mathrm{Mg} \\
\mathrm{ug} / \mathrm{L}\end{array}$ & $\begin{array}{r}\mathrm{Al} \\
\mathrm{ug} / \mathrm{L}\end{array}$ & $\begin{array}{r}\mathrm{Si} \\
\mathrm{ug} / \mathrm{L}\end{array}$ & $\begin{array}{r}\mathbf{K} \\
\mathrm{ug} / \mathrm{L}\end{array}$ & $\begin{array}{r}\mathrm{Ca} \\
\mathrm{ug} / \mathrm{L}\end{array}$ & $\begin{array}{r}\mathrm{Sc} \\
\mathrm{ug} / \mathrm{L}\end{array}$ & $\begin{array}{r}\mathbf{T i} \\
\mathrm{ug} / \mathrm{L}\end{array}$ & $\begin{array}{r}V \\
u g / L\end{array}$ & $\begin{array}{r}\mathrm{Cr} \\
\mathrm{ug} / \mathrm{L}\end{array}$ & $\begin{array}{c}\mathrm{Mn} \\
\mathrm{ug} / \mathrm{L}\end{array}$ & $\begin{array}{r}\mathrm{Fe} \\
\mathrm{ug} / \mathrm{L}\end{array}$ & $\begin{array}{r}\mathrm{Co} \\
\mathrm{ug} / \mathrm{L}\end{array}$ & $\begin{array}{r}\mathrm{Ni} \\
\mathrm{ug} / \mathrm{L}\end{array}$ & $\begin{array}{r}\mathrm{Cu} \\
\mathbf{u g} / \mathrm{L}\end{array}$ \\
\hline MDL & 2 & 2 & 200 & 30 & 700 & 1 & 0.1 & 0.1 & 0.05 & 0.1 & 10 & 0.005 & 0.3 & 0.2 \\
\hline LRMSHS-s20-0102 & 30300 & & 2800 & 2380 & 62700 & $<\mathrm{MDL}$ & $<\mathrm{MDL}$ & $<\mathrm{MDL}$ & $<\mathrm{MDL}$ & 3.3 & $<\mathrm{MDL}$ & 0.02 & $<\mathrm{MDL}$ & 0.3 \\
\hline LRM000-s20-0119 & 36800 & 210 & 7500 & 4790 & 96200 & $<\mathrm{MDL}$ & $<\mathrm{MDL}$ & $<\mathrm{MDL}$ & $<\mathrm{MDL}$ & 2520 & 250 & 5.06 & 14.2 & 0.4 \\
\hline LRM050-s20-0119 & 39600 & 30 & 8000 & 4380 & 125000 & $<\mathrm{MDL}$ & $<\mathrm{MDL}$ & $<\mathrm{MDL}$ & $<\mathrm{MDL}$ & 555 & 110 & 0.91 & 7.5 & $<\mathrm{MDL}$ \\
\hline LRM172-s20-0119 & 36800 & 4 & 7300 & 4040 & 83200 & $<\mathrm{MDL}$ & $<\mathrm{MDL}$ & $<\mathrm{MDL}$ & $<\mathrm{MDL}$ & 375 & 50 & 0.291 & 3.9 & $<\mathrm{MDL}$ \\
\hline LRMSHS-s20-0119 & 28700 & 8 & 3800 & 2170 & 60300 & $<\mathrm{MDL}$ & $<\mathrm{MDL}$ & $<\mathrm{MDL}$ & $<\mathrm{MDL}$ & 5 & 20 & 0.023 & $<\mathrm{MDL}$ & 0.4 \\
\hline LRM000-s20-0202 & 36200 & 279 & 7300 & 4150 & 109000 & $<\mathrm{MDL}$ & $<\mathrm{MDL}$ & $<\mathrm{MDL}$ & $<\mathrm{MDL}$ & 1560 & 100 & 3.78 & 11.9 & 0.3 \\
\hline LRM050-s20-0202 & 32100 & 19 & 7500 & 4930 & 113000 & $<\mathrm{MDL}$ & 0.7 & $<\mathrm{MDL}$ & $<\mathrm{MDL}$ & 277 & 70 & 0.131 & 6.4 & $<\mathrm{MDL}$ \\
\hline LRM172-s20-0202 & 32400 & 3 & 7100 & 4850 & 107000 & $<\mathrm{MDL}$ & 0.7 & $<\mathrm{MDL}$ & $<\mathrm{MDL}$ & 192 & 30 & $<\mathrm{MDL}$ & 3.5 & $<\mathrm{MDL}$ \\
\hline LRMSHS-s20-0202 & 31200 & 5 & 3600 & 2790 & 78700 & $<\mathrm{MDL}$ & $<\mathrm{MDL}$ & $<\mathrm{MDL}$ & $<\mathrm{MDL}$ & 10.2 & $<\mathrm{MDL}$ & $<\mathrm{MDL}$ & $<\mathrm{MDL}$ & 0.8 \\
\hline LRM000-s20-0216 & 35500 & 175 & 6400 & 3800 & 107000 & $<\mathrm{MDL}$ & $<\mathrm{MDL}$ & $<\mathrm{MDL}$ & $<\mathrm{MDL}$ & 1690 & 20 & 3.34 & 10.7 & 0.5 \\
\hline LRM050-s20-0216 & 33300 & 24 & 6700 & 4590 & 110000 & $<\mathrm{MDL}$ & 0.7 & $<\mathrm{MDL}$ & $<\mathrm{MDL}$ & 251 & 60 & $<\mathrm{MDL}$ & 8.8 & $<\mathrm{MDL}$ \\
\hline LRM172-s20-0216 & 33300 & 4 & 6200 & 4410 & 101000 & $<\mathrm{MDL}$ & 0.6 & $<\mathrm{MDL}$ & $<\mathrm{MDL}$ & 204 & 20 & $<\mathrm{MDL}$ & 5.3 & $<\mathrm{MDL}$ \\
\hline LRMSHS-s20-0216 & 29300 & & 4000 & 2260 & 77800 & $<\mathrm{MDL}$ & $<\mathrm{MDL}$ & $<\mathrm{MDL}$ & $<\mathrm{MDL}$ & 4.6 & $<\mathrm{MDL}$ & $<\mathrm{MDL}$ & $<\mathrm{MDL}$ & $<\mathrm{MDL}$ \\
\hline LRM000-s20-0229 & 48500 & 119 & 7000 & 4390 & 145000 & $<\mathrm{MDL}$ & $<\mathrm{MDL}$ & $<\mathrm{MDL}$ & $<$ MDL & 1560 & 60 & 2.45 & 11.9 & $<\mathrm{MDL}$ \\
\hline LRM050-s20-0229 & 50700 & 27 & 7300 & 3910 & 151000 & $<\mathrm{MDL}$ & 1.3 & $<\mathrm{MDL}$ & $<\mathrm{MDL}$ & 436 & 60 & $<\mathrm{MDL}$ & 13.9 & $<\mathrm{MDL}$ \\
\hline LRM172-s20-0229 & 48100 & 4 & 6800 & 3740 & 147000 & $<\mathrm{MDL}$ & 0.6 & $<\mathrm{MDL}$ & $<\mathrm{MDL}$ & 303 & 30 & $<\mathrm{MDL}$ & 9.4 & $<\mathrm{MDL}$ \\
\hline LRMSHS-s20-0229 & 28900 & & 3700 & 2670 & 75500 & $<\mathrm{MDL}$ & $<\mathrm{MDL}$ & $<\mathrm{MDL}$ & $<\mathrm{MDL}$ & 6.9 & $<\mathrm{MDL}$ & $<\mathrm{MDL}$ & $<\mathrm{MDL}$ & $<\mathrm{MDL}$ \\
\hline \multicolumn{15}{|l|}{ LRM000-s20-0314 } \\
\hline \multicolumn{15}{|l|}{ LRM050-s20-0314 } \\
\hline \multicolumn{15}{|l|}{ LRM172-s20-0314 } \\
\hline LRMSHS-s20-0314 & & & & & & & & & & & & & & \\
\hline
\end{tabular}

Blank cells indiate no data collected

MDL $=$ Method Detection Limit

$<\mathrm{MDL}=$ parameter not detecteble above the method detection limit 


\begin{tabular}{|c|c|c|c|c|c|c|c|c|c|c|c|c|c|c|}
\hline Tracking ID & $\begin{array}{r}\mathrm{Zn} \\
\mathrm{ug} / \mathrm{L}\end{array}$ & $\begin{array}{r}\mathbf{G a} \\
\mathbf{u g} / \mathrm{L}\end{array}$ & $\begin{array}{r}\mathrm{Ge} \\
\mathrm{ug} / \mathrm{L}\end{array}$ & $\begin{array}{r}\text { As } \\
\mathrm{ug} / \mathrm{L}\end{array}$ & $\begin{array}{r}\mathrm{Se} \\
\mathrm{ug} / \mathrm{L}\end{array}$ & $\begin{array}{r}\text { Rb } \\
\text { ug/L }\end{array}$ & $\begin{array}{r}\mathrm{Sr} \\
\mathrm{ug} / \mathrm{L}\end{array}$ & $\begin{array}{r}\mathrm{Y} \\
\mathrm{ug} / \mathrm{L}\end{array}$ & $\begin{array}{r}\mathrm{Zr} \\
\mathrm{ug} / \mathrm{L}\end{array}$ & $\begin{array}{r}\mathrm{Nb} \\
\mathrm{ug} / \mathrm{L}\end{array}$ & $\begin{array}{c}\text { Mo } \\
\text { ug/L }\end{array}$ & $\begin{array}{r}\mathrm{Ag} \\
\mathrm{ug} / \mathrm{L}\end{array}$ & $\begin{array}{r}\mathrm{Cd} \\
\mathrm{ug} / \mathrm{L}\end{array}$ & $\begin{array}{r}\text { In } \\
\text { ug/L }\end{array}$ \\
\hline MDL & 0.5 & 0.01 & 0.01 & 0.03 & 0.2 & 0.005 & 0.04 & 0.003 & 0.01 & 0.005 & 0.1 & 0.2 & 0.01 & 0.001 \\
\hline LRM000-s19-1018 & $<\mathrm{MDL}$ & 0.25 & 0.05 & 0.3 & 0.6 & 5.79 & 1700 & 0.008 & 0.02 & $<\mathrm{MDL}$ & $<\mathrm{MDL}$ & $<\mathrm{MDL}$ & 0.08 & 0.001 \\
\hline LRM050-s19-1018 & $<\mathrm{MDL}$ & 0.06 & 0.02 & 0.11 & 0.4 & 3.98 & 1690 & 0.013 & 0.03 & $<\mathrm{MDL}$ & $<\mathrm{MDL}$ & $<\mathrm{MDL}$ & 0.08 & 0.001 \\
\hline LRM172-s19-1018 & $<\mathrm{MDL}$ & $<\mathrm{MDL}$ & $<\mathrm{MDL}$ & 0.09 & $<\mathrm{MDL}$ & 3.72 & 1650 & 0.02 & 0.06 & $<\mathrm{MDL}$ & $<\mathrm{MDL}$ & $<\mathrm{MDL}$ & 0.04 & 0.001 \\
\hline \multicolumn{15}{|l|}{ LRM000-s19-1024 } \\
\hline \multicolumn{15}{|l|}{ LRM050-s19-1024 } \\
\hline \multicolumn{15}{|l|}{ LRM172-s19-1024 } \\
\hline LRM000-s19-1102 & $<\mathrm{MDL}$ & 0.26 & 0.05 & 0.31 & 0.7 & 5.82 & 1710 & $<\mathrm{MDL}$ & 0.02 & $<\mathrm{MDL}$ & $<\mathrm{MDL}$ & $<\mathrm{MDL}$ & 0.07 & 0.001 \\
\hline LRM050-s19-1102 & $<\mathrm{MDL}$ & 0.08 & 0.03 & 0.12 & 0.4 & 4.34 & 1680 & $<\mathrm{MDL}$ & 0.02 & $<\mathrm{MDL}$ & $<\mathrm{MDL}$ & $<\mathrm{MDL}$ & 0.07 & 0.001 \\
\hline LRM172-s19-1102 & $<\mathrm{MDL}$ & $<\mathrm{MDL}$ & $<\mathrm{MDL}$ & 0.09 & $<\mathrm{MDL}$ & 3.94 & 1630 & 0.003 & 0.02 & $<\mathrm{MDL}$ & $<\mathrm{MDL}$ & $<\mathrm{MDL}$ & 0.04 & 0.001 \\
\hline \multicolumn{15}{|l|}{ LRM000-s19-1110 } \\
\hline \multicolumn{15}{|l|}{ LRM050-s19-1110 } \\
\hline \multicolumn{15}{|l|}{ LRM172-s19-1110 } \\
\hline LRM000-s19-1118 & 60.9 & 0.41 & 0.07 & 0.52 & 0.9 & 5.97 & 1770 & 5.77 & $<\mathrm{MDL}$ & $<\mathrm{MDL}$ & $<\mathrm{MDL}$ & $<\mathrm{MDL}$ & 0.07 & 0.001 \\
\hline LRM050-s19-1118 & 42.2 & 0.14 & 0.04 & 0.21 & 0.5 & 4.8 & 1750 & 2.48 & $<\mathrm{MDL}$ & $<$ MDL & $<\mathrm{MDL}$ & $<\mathrm{MDL}$ & 0.08 & 0.001 \\
\hline LRM172-s19-1118 & 14.7 & $<$ MDL & $<\mathrm{MDL}$ & 0.12 & $<\mathrm{MDL}$ & 4.58 & 1730 & 0.108 & $<\mathrm{MDL}$ & $<\mathrm{MDL}$ & $<\mathrm{MDL}$ & $<\mathrm{MDL}$ & 0.04 & 0.001 \\
\hline LRM000-s19-1203 & 87.9 & 0.41 & 0.08 & 0.56 & 1 & 5.88 & 1780 & 5.88 & $<\mathrm{MDL}$ & $<\mathrm{MDL}$ & $<\mathrm{MDL}$ & $<\mathrm{MDL}$ & 0.07 & 0.001 \\
\hline LRM050-s19-1203 & 35.8 & 0.13 & 0.03 & 0.26 & 0.6 & 4.71 & 1790 & 2.57 & $<\mathrm{MDL}$ & $<$ MDL & $<\mathrm{MDL}$ & $<\mathrm{MDL}$ & 0.07 & 0.001 \\
\hline LRM172-s19-1203 & 22.3 & $<$ MDL & $<\mathrm{MDL}$ & 0.12 & 0.2 & 4.3 & 1760 & 0.105 & $<\mathrm{MDL}$ & $<\mathrm{MDL}$ & $<\mathrm{MDL}$ & $<\mathrm{MDL}$ & 0.04 & 0.002 \\
\hline \multicolumn{15}{|l|}{ LRM000-s19-1211 } \\
\hline \multicolumn{15}{|l|}{ LRM050-s19-1211 } \\
\hline \multicolumn{15}{|l|}{ LRM172-s19-1211 } \\
\hline \multicolumn{15}{|l|}{ LRMSHS-s19-1211 } \\
\hline LRM000-s19-1218 & 25.1 & 0.11 & 0.03 & 0.15 & 1.2 & 4.48 & 1590 & 3.03 & $<\mathrm{MDL}$ & $<\mathrm{MDL}$ & $<\mathrm{MDL}$ & $<\mathrm{MDL}$ & 0.05 & $<\mathrm{MDL}$ \\
\hline LRM050-s19-1218 & 17.9 & 0.02 & 0.01 & 0.07 & 1.2 & 3.22 & 1330 & 0.773 & $<\mathrm{MDL}$ & $<\mathrm{MDL}$ & $<\mathrm{MDL}$ & $<\mathrm{MDL}$ & 0.03 & $<\mathrm{MDL}$ \\
\hline LRM172-s19-1218 & 17.9 & $<\mathrm{MDL}$ & $<\mathrm{MDL}$ & 0.11 & 1 & 2.46 & 1010 & 0.084 & $<\mathrm{MDL}$ & $<\mathrm{MDL}$ & $<\mathrm{MDL}$ & $<\mathrm{MDL}$ & 0.02 & $<\mathrm{MDL}$ \\
\hline LRMSHS-d19-1218 & 9.3 & $<\mathrm{MDL}$ & $<\mathrm{MDL}$ & 0.2 & 1.1 & 0.524 & 1290 & 0.047 & 0.02 & $<\mathrm{MDL}$ & 1.4 & $<\mathrm{MDL}$ & $<\mathrm{MDL}$ & $<\mathrm{MDL}$ \\
\hline LRMSHS-s19-1218 & 6.1 & $<\mathrm{MDL}$ & $<\mathrm{MDL}$ & 0.19 & 1.2 & 0.535 & 1260 & 0.048 & 0.03 & $<\mathrm{MDL}$ & 1.4 & $<\mathrm{MDL}$ & $<\mathrm{MDL}$ & $<\mathrm{MDL}$ \\
\hline LRM000-s20-0102 & 76.5 & 0.11 & 0.03 & 0.12 & 0.9 & 5.2 & 1670 & 2.69 & $<\mathrm{MDL}$ & $<\mathrm{MDL}$ & $<\mathrm{MDL}$ & $<\mathrm{MDL}$ & 0.04 & $<\mathrm{MDL}$ \\
\hline LRM050-s20-0102 & 47.2 & 0.02 & 0.01 & 0.09 & 0.9 & 3.54 & 1490 & 0.84 & $<\mathrm{MDL}$ & $<\mathrm{MDL}$ & $<\mathrm{MDL}$ & $<\mathrm{MDL}$ & 0.03 & $<\mathrm{MDL}$ \\
\hline LRM172-s20-0102 & 9.4 & $<\mathrm{MDL}$ & $<\mathrm{MDL}$ & 0.06 & 0.6 & 3.69 & 1370 & 0.066 & $<\mathrm{MDL}$ & $<\mathrm{MDL}$ & $<\mathrm{MDL}$ & $<\mathrm{MDL}$ & 0.02 & $<\mathrm{MDL}$ \\
\hline
\end{tabular}

Blank cells indiate no data collected

MDL $=$ Method Detection Limit

$<\mathrm{MDL}=$ parameter not detecteble above the method detection limit 


\begin{tabular}{|c|c|c|c|c|c|c|c|c|c|c|c|c|c|c|}
\hline Tracking ID & $\begin{array}{r}\mathrm{Zn} \\
\mathbf{u g} / \mathrm{L}\end{array}$ & $\begin{array}{r}\mathbf{G a} \\
\mathbf{u g} / \mathrm{L}\end{array}$ & $\begin{array}{r}\mathbf{G e} \\
\mathbf{u g} / \mathrm{L}\end{array}$ & $\begin{array}{r}\text { As } \\
\text { ug/L }\end{array}$ & $\begin{array}{r}\mathrm{Se} \\
\mathrm{ug} / \mathrm{L}\end{array}$ & $\begin{array}{r}\text { Rb } \\
\text { ug/L } / L\end{array}$ & $\begin{array}{r}\mathrm{Sr} \\
\mathrm{ug} / \mathrm{L}\end{array}$ & $\begin{array}{r}\mathrm{Y} \\
\mathrm{ug} / \mathrm{L}\end{array}$ & $\begin{array}{r}\mathrm{Zr} \\
\mathbf{u g} / \mathrm{L}\end{array}$ & $\begin{array}{r}\mathrm{Nb} \\
\mathrm{ug} / \mathrm{L}\end{array}$ & $\begin{array}{r}\text { Mo } \\
\text { ug/L }\end{array}$ & $\begin{array}{r}\mathrm{Ag} \\
\mathrm{ug} / \mathrm{L}\end{array}$ & $\begin{array}{r}\mathrm{Cd} \\
\mathrm{ug} / \mathrm{L}\end{array}$ & $\begin{array}{r}\text { In } \\
\text { ug/L }\end{array}$ \\
\hline MDL & 0.5 & 0.01 & 0.01 & 0.03 & 0.2 & 0.005 & 0.04 & 0.003 & 0.01 & 0.005 & 0.1 & 0.2 & 0.01 & 0.001 \\
\hline LRMSHS-s20-0102 & 18.7 & $<\mathrm{MDL}$ & $<\mathrm{MDL}$ & 0.24 & 1.3 & 0.572 & 2240 & 0.048 & 0.01 & $<\mathrm{MDL}$ & 2.4 & $<\mathrm{MDL}$ & 0.01 & $<\mathrm{MDL}$ \\
\hline LRM000-s20-0119 & 73.7 & 0.06 & 0.02 & 0.09 & 0.8 & 4.68 & 1630 & 1.62 & $<\mathrm{MDL}$ & $<$ MDL & $<\mathrm{MDL}$ & $<\mathrm{MDL}$ & 0.03 & $<\mathrm{MDL}$ \\
\hline LRM050-s20-0119 & 18.5 & 0.01 & 0.01 & 0.06 & 0.9 & 3.43 & 1380 & 0.642 & $<\mathrm{MDL}$ & $<\mathrm{MDL}$ & $<\mathrm{MDL}$ & $<\mathrm{MDL}$ & 0.02 & $<\mathrm{MDL}$ \\
\hline LRM172-s20-0119 & 32.2 & $<\mathrm{MDL}$ & $<\mathrm{MDL}$ & 0.07 & 0.7 & 2.77 & 1260 & 0.054 & $<\mathrm{MDL}$ & $<\mathrm{MDL}$ & $<\mathrm{MDL}$ & $<\mathrm{MDL}$ & 0.01 & $<\mathrm{MDL}$ \\
\hline LRMSHS-s20-0119 & 8.4 & $<\mathrm{MDL}$ & $<\mathrm{MDL}$ & 0.17 & 1 & 0.711 & 1960 & 0.068 & 0.03 & $<\mathrm{MDL}$ & 2.2 & $<\mathrm{MDL}$ & 0.01 & $<\mathrm{MDL}$ \\
\hline LRM000-s20-0202 & 29.8 & 0.12 & 0.03 & 0.17 & 1 & 4.77 & 1330 & 1.65 & $<\mathrm{MDL}$ & $<\mathrm{MDL}$ & $<\mathrm{MDL}$ & $<\mathrm{MDL}$ & 0.03 & $<\mathrm{MDL}$ \\
\hline LRM050-s20-0202 & 17.8 & 0.02 & 0.01 & 0.1 & 0.9 & 3.21 & 1030 & 0.633 & $<\mathrm{MDL}$ & $<\mathrm{MDL}$ & $<\mathrm{MDL}$ & $<\mathrm{MDL}$ & $<\mathrm{MDL}$ & $<\mathrm{MDL}$ \\
\hline LRM172-s20-0202 & 9.3 & $<\mathrm{MDL}$ & $<\mathrm{MDL}$ & 0.07 & 0.9 & 3.12 & 1060 & 0.049 & $<\mathrm{MDL}$ & $<\mathrm{MDL}$ & $<\mathrm{MDL}$ & $<\mathrm{MDL}$ & $<\mathrm{MDL}$ & $<\mathrm{MDL}$ \\
\hline LRMSHS-s20-0202 & 3 & $<\mathrm{MDL}$ & $<\mathrm{MDL}$ & 0.19 & 1.1 & 0.909 & 2070 & 0.047 & $<\mathrm{MDL}$ & $<\mathrm{MDL}$ & 3.2 & $<\mathrm{MDL}$ & $<\mathrm{MDL}$ & $<\mathrm{MDL}$ \\
\hline LRM000-s20-0216 & 23.6 & 0.1 & 0.01 & 0.12 & 0.7 & 4.04 & 1390 & 1.11 & $<\mathrm{MDL}$ & $<\mathrm{MDL}$ & $<\mathrm{MDL}$ & $<\mathrm{MDL}$ & 0.07 & $<\mathrm{MDL}$ \\
\hline LRM050-s20-0216 & 20.4 & 0.02 & 0.01 & 0.08 & 1.3 & 2.86 & 1060 & 0.656 & $<\mathrm{MDL}$ & $<\mathrm{MDL}$ & $<\mathrm{MDL}$ & $<\mathrm{MDL}$ & 0.03 & $<\mathrm{MDL}$ \\
\hline LRM172-s20-0216 & 12.1 & $<\mathrm{MDL}$ & $<\mathrm{MDL}$ & 0.08 & 1 & 2.59 & 1070 & 0.087 & $<\mathrm{MDL}$ & $<\mathrm{MDL}$ & $<\mathrm{MDL}$ & $<\mathrm{MDL}$ & 0.02 & $<\mathrm{MDL}$ \\
\hline LRMSHS-s20-0216 & 6.4 & $<\mathrm{MDL}$ & $<\mathrm{MDL}$ & 0.15 & 1.3 & 0.849 & 1670 & 0.046 & $<\mathrm{MDL}$ & $<\mathrm{MDL}$ & 3.3 & $<\mathrm{MDL}$ & $<\mathrm{MDL}$ & $<\mathrm{MDL}$ \\
\hline LRM000-s20-0229 & 11.6 & 0.07 & 0.01 & 0.11 & 0.7 & 4.3 & 2030 & 0.927 & $<\mathrm{MDL}$ & $<\mathrm{MDL}$ & $<\mathrm{MDL}$ & $<\mathrm{MDL}$ & 0.07 & 0.001 \\
\hline LRM050-s20-0229 & 17.6 & 0.03 & 0.02 & 0.09 & 1.1 & 3.59 & 1670 & 0.886 & $<\mathrm{MDL}$ & $<\mathrm{MDL}$ & $<\mathrm{MDL}$ & $<\mathrm{MDL}$ & 0.06 & 0.001 \\
\hline LRM172-s20-0229 & 8.3 & $<\mathrm{MDL}$ & $<\mathrm{MDL}$ & 0.08 & 1.1 & 3.42 & 1610 & 0.191 & $<\mathrm{MDL}$ & $<\mathrm{MDL}$ & $<\mathrm{MDL}$ & $<\mathrm{MDL}$ & 0.03 & $<\mathrm{MDL}$ \\
\hline LRMSHS-s20-0229 & 5.8 & $<\mathrm{MDL}$ & $<\mathrm{MDL}$ & 0.15 & 1.2 & 0.872 & 1930 & 0.044 & $<\mathrm{MDL}$ & $<\mathrm{MDL}$ & 3.2 & $<\mathrm{MDL}$ & $<\mathrm{MDL}$ & $<\mathrm{MDL}$ \\
\hline \multicolumn{15}{|l|}{ LRM000-s20-0314 } \\
\hline \multicolumn{15}{|l|}{ LRM050-s20-0314 } \\
\hline \multicolumn{15}{|l|}{ LRM172-s20-0314 } \\
\hline LRMSHS-s20-0314 & & & & & & & & & & & & & & \\
\hline
\end{tabular}

Blank cells indiate no data collected

MDL $=$ Method Detection Limit

$<\mathrm{MDL}=$ parameter not detecteble above the method detection limit 


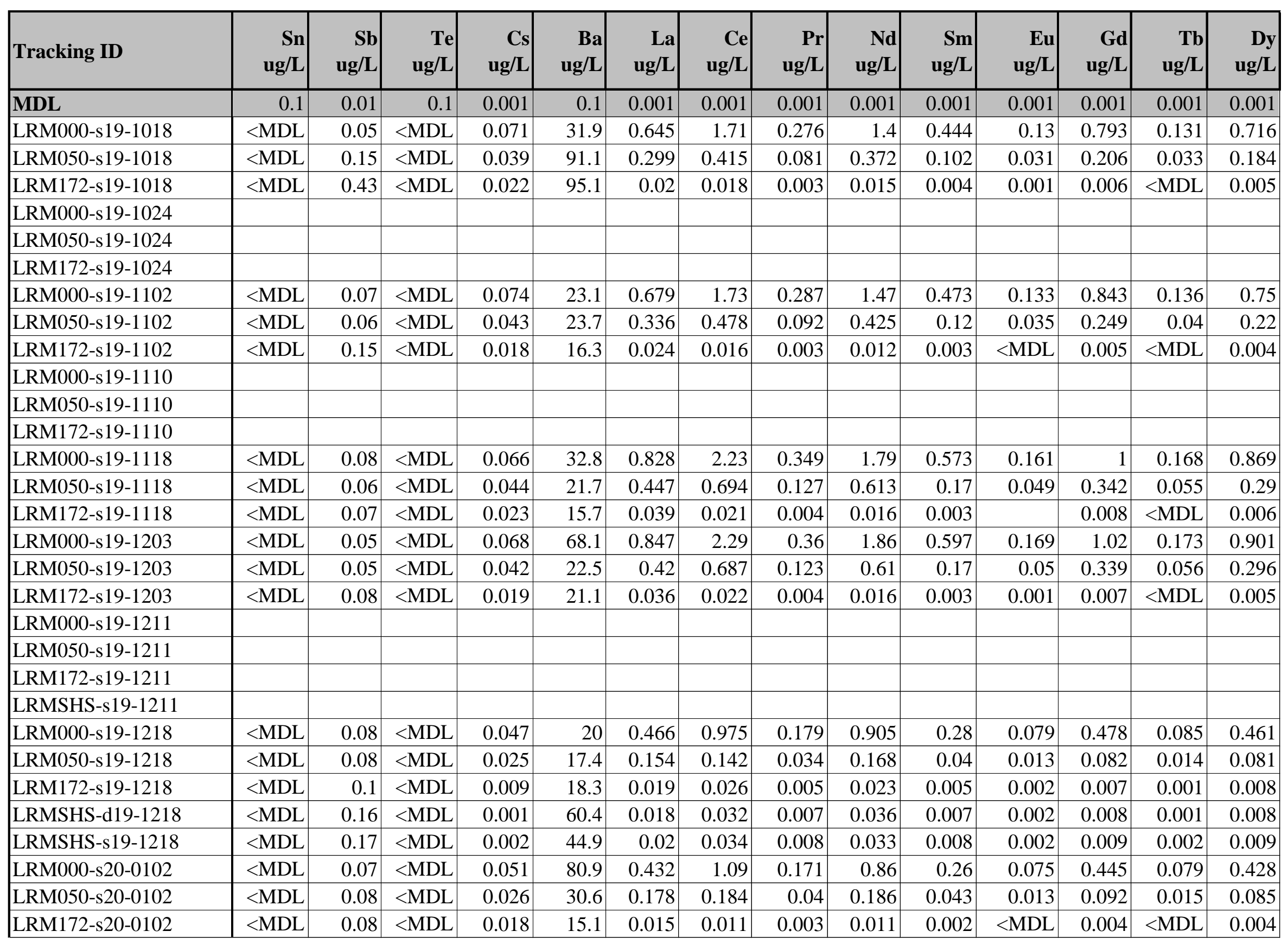

Blank cells indiate no data collected

MDL $=$ Method Detection Limit

$<\mathrm{MDL}=$ parameter not detecteble above the method detection limit 


\begin{tabular}{|c|c|c|c|c|c|c|c|c|c|c|c|c|c|c|}
\hline Tracking ID & $\begin{array}{r}\mathrm{Sn} \\
\mathrm{ug} / \mathrm{L}\end{array}$ & $\begin{array}{r}\mathrm{Sb} \\
\mathrm{ug} / \mathrm{L}\end{array}$ & $\begin{array}{r}\text { Te } \\
\text { ug/L }\end{array}$ & $\begin{array}{r}\mathrm{Cs} \\
\mathrm{ug} / \mathrm{L}\end{array}$ & $\begin{array}{r}\text { Ba } \\
\text { ug/L }\end{array}$ & $\begin{array}{r}\text { La } \\
\text { ug/L }\end{array}$ & $\begin{array}{r}\mathrm{Ce} \\
\mathrm{ug} / \mathrm{L}\end{array}$ & $\begin{array}{r}\operatorname{Pr} \\
\text { ug/L }\end{array}$ & $\begin{array}{r}\text { Nd } \\
\text { ug/L }\end{array}$ & $\begin{array}{r}\mathrm{Sm} \\
\mathrm{ug} / \mathrm{L}\end{array}$ & $\begin{array}{r}\mathrm{Eu} \\
\mathbf{u g} / \mathrm{L}\end{array}$ & $\begin{array}{r}\text { Gd } \\
\mathbf{u g} / \mathrm{L}\end{array}$ & $\begin{array}{r}\mathrm{Tb} \\
\mathrm{ug} / \mathrm{L}\end{array}$ & $\begin{array}{r}\text { Dy } \\
\text { ug/L }\end{array}$ \\
\hline MDL & 0.1 & 0.01 & 0.1 & 0.001 & 0.1 & 0.001 & 0.001 & 0.001 & 0.001 & 0.001 & 0.001 & 0.001 & 0.001 & 0.001 \\
\hline LRM000-s20-0119 & $<\mathrm{MDL}$ & 0.08 & $<\mathrm{MDL}$ & 0.043 & 120 & 0.265 & 0.602 & 0.09 & 0.45 & 0.129 & 0.038 & 0.234 & 0.041 & 0.227 \\
\hline LRM050-s20-0119 & $<\mathrm{MDL}$ & 0.09 & $<\mathrm{MDL}$ & 0.028 & 19.5 & 0.131 & 0.095 & 0.027 & 0.129 & 0.031 & 0.009 & 0.063 & 0.011 & 0.061 \\
\hline LRM172-s20-0119 & $<\mathrm{MDL}$ & 0.1 & $<\mathrm{MDL}$ & 0.012 & 29.3 & 0.012 & 0.011 & 0.002 & 0.012 & 0.003 & $<\mathrm{MDL}$ & 0.004 & $<\mathrm{MDL}$ & 0.004 \\
\hline LRM000-s20-0202 & $<\mathrm{MDL}$ & 0.07 & $<\mathrm{MDL}$ & 0.044 & 27.3 & 0.243 & 0.601 & 0.092 & 0.482 & 0.149 & 0.043 & 0.272 & 0.045 & 0.239 \\
\hline LRM050-s20-0202 & $<\mathrm{MDL}$ & 0.09 & $<\mathrm{MDL}$ & 0.024 & 24.8 & 0.126 & 0.074 & 0.025 & 0.123 & 0.028 & 0.009 & 0.065 & 0.01 & 0.055 \\
\hline LRM172-s20-0202 & $<\mathrm{MDL}$ & 0.08 & $<\mathrm{MDL}$ & 0.015 & 19.2 & 0.006 & 0.004 & $<\mathrm{MDL}$ & 0.005 & $<\mathrm{MDL}$ & $<\mathrm{MDL}$ & 0.002 & $<\mathrm{MDL}$ & 0.003 \\
\hline LRMSHS-s20-0202 & $<\mathrm{MDL}$ & 0.17 & $<\mathrm{MDL}$ & 0.001 & 73.9 & 0.007 & 0.012 & 0.003 & 0.013 & 0.004 & 0.002 & 0.005 & $<\mathrm{MDL}$ & 0.005 \\
\hline LRM000-s20-0216 & $<\mathrm{MDL}$ & 0.07 & $<\mathrm{MDL}$ & 0.036 & 32.7 & 0.204 & 0.532 & 0.073 & 0.351 & 0.099 & 0.03 & 0.183 & 0.031 & 0.162 \\
\hline LRM050-s20-0216 & $<\mathrm{MDL}$ & 0.08 & $<\mathrm{MDL}$ & 0.021 & 27.6 & 0.14 & 0.077 & 0.03 & 0.139 & 0.032 & 0.01 & 0.067 & 0.011 & 0.055 \\
\hline LRM172-s20-0229 & $<\mathrm{MDL}$ & 0.11 & $<\mathrm{MDL}$ & 0.021 & 23.4 & 0.046 & 0.019 & 0.006 & 0.029 & 0.005 & 0.002 & 0.014 & 0.002 & 0.011 \\
\hline LRMSHS-s20-0229 & $<\mathrm{MDL}$ & 0.17 & $<\mathrm{MDL}$ & 0.001 & 72.9 & 0.003 & 0.006 & 0.002 & 0.011 & 0.003 & 0.002 & 0.004 & $<\mathrm{MDL}$ & 0.004 \\
\hline \multicolumn{15}{|l|}{ LRM000-s20-0314 } \\
\hline \multicolumn{15}{|l|}{ LRM050-s20-0314 } \\
\hline \multicolumn{15}{|l|}{ LRM172-s20-0314 } \\
\hline LRMSHS-s20-0314 & & & & & & & & & & & & & & \\
\hline
\end{tabular}

Blank cells indiate no data collected

MDL $=$ Method Detection Limit

$<\mathrm{MDL}=$ parameter not detecteble above the method detection limit 


\begin{tabular}{|c|c|c|c|c|c|c|c|c|c|c|c|c|c|c|}
\hline Tracking ID & $\begin{array}{r}\text { Ho } \\
\text { ug/L }\end{array}$ & $\begin{array}{r}\text { Er } \\
\text { ug/L }\end{array}$ & $\underset{\text { ug/L }}{\mathbf{T m}}$ & $\begin{array}{r}\mathbf{Y b} \\
\mathbf{u g} / \mathrm{L}\end{array}$ & $\begin{array}{r}\mathbf{L u} \\
\mathbf{u g} / \mathrm{L}\end{array}$ & $\begin{array}{r}\text { Hf } \\
\text { ug/L }\end{array}$ & $\begin{array}{r}\mathrm{Ta} \\
\mathrm{ug} / \mathrm{L}\end{array}$ & $\begin{array}{r}W \\
\mathrm{ug} / \mathrm{L}\end{array}$ & $\begin{array}{r}\mathrm{Hg} \\
\mathrm{ug} / \mathrm{L}\end{array}$ & $\begin{array}{r}\mathrm{Tl} \\
\mathrm{ug} / \mathrm{L}\end{array}$ & $\begin{array}{r}\mathbf{P b} \\
\mathbf{u g} / \mathrm{L}\end{array}$ & $\begin{array}{r}\mathrm{Bi} \\
\mathrm{ug} / \mathrm{L}\end{array}$ & $\begin{array}{r}\text { Th } \\
\text { ug/L }\end{array}$ & $\begin{array}{r}\mathrm{U} \\
\mathrm{ug} / \mathrm{L}\end{array}$ \\
\hline MDL & 0.001 & 0.001 & 0.001 & 0.001 & 0.001 & 0.001 & 0.001 & 0.02 & 0.2 & 0.001 & 0.01 & 0.3 & 0.001 & 0.001 \\
\hline LRM000-s19-1018 & 0.14 & 0.353 & 0.043 & 0.233 & 0.031 & 0.002 & $<\mathrm{MDL}$ & $<\mathrm{MDL}$ & $<\mathrm{MDL}$ & 0.286 & 0.03 & $<\mathrm{MDL}$ & 0.03 & 0.089 \\
\hline LRM050-s19-1018 & 0.035 & 0.088 & 0.011 & 0.049 & 0.008 & 0.001 & $<\mathrm{MDL}$ & $<\mathrm{MDL}$ & $<\mathrm{MDL}$ & 0.093 & 0.02 & $<\mathrm{MDL}$ & 0.033 & 0.036 \\
\hline LRM172-s19-1018 & 0.001 & 0.003 & $<\mathrm{MDL}$ & 0.002 & $<\mathrm{MDL}$ & 0.002 & $<\mathrm{MDL}$ & 0.02 & $<\mathrm{MDL}$ & 0.033 & 0.05 & $<\mathrm{MDL}$ & 0.043 & 0.019 \\
\hline \multicolumn{15}{|l|}{ LRM000-s19-1024 } \\
\hline \multicolumn{15}{|l|}{ LRM050-s19-1024 } \\
\hline \multicolumn{15}{|l|}{ LRM172-s19-1024 } \\
\hline LRM000-s19-1102 & 0.143 & 0.367 & 0.044 & 0.233 & 0.033 & 0.002 & $<\mathrm{MDL}$ & $<\mathrm{MDL}$ & $<\mathrm{MDL}$ & 0.298 & 0.03 & $<\mathrm{MDL}$ & 0.014 & 0.089 \\
\hline LRM050-s19-1102 & 0.044 & 0.112 & 0.012 & 0.061 & 0.008 & $<\mathrm{MDL}$ & $<\mathrm{MDL}$ & $<\mathrm{MDL}$ & $<\mathrm{MDL}$ & 0.13 & 0.01 & $<\mathrm{MDL}$ & 0.009 & 0.039 \\
\hline LRM172-s19-1102 & 0.001 & 0.002 & $<\mathrm{MDL}$ & 0.001 & $<\mathrm{MDL}$ & $<\mathrm{MDL}$ & $<\mathrm{MDL}$ & $<\mathrm{MDL}$ & $<\mathrm{MDL}$ & 0.053 & $<\mathrm{MDL}$ & $<\mathrm{MDL}$ & 0.008 & 0.017 \\
\hline \multicolumn{15}{|l|}{ LRM000-s19-1110 } \\
\hline \multicolumn{15}{|l|}{ LRM050-s19-1110 } \\
\hline \multicolumn{15}{|l|}{ LRM172-s19-1110 } \\
\hline LRM000-s19-1118 & 0.17 & 0.434 & 0.051 & 0.268 & 0.037 & 0.002 & $<\mathrm{MDL}$ & $<\mathrm{MDL}$ & $<\mathrm{MDL}$ & 0.264 & 0.02 & $<\mathrm{MDL}$ & 0.008 & 0.092 \\
\hline LRM050-s19-1118 & 0.057 & 0.144 & 0.016 & 0.079 & 0.011 & $<$ MDL & $<\mathrm{MDL}$ & $<\mathrm{MDL}$ & $<$ MDL & 0.141 & $<\mathrm{MDL}$ & $<$ MDL & 0.004 & 0.038 \\
\hline LRM172-s19-1118 & 0.001 & 0.003 & $<\mathrm{MDL}$ & 0.001 & $<\mathrm{MDL}$ & $<\mathrm{MDL}$ & $<\mathrm{MDL}$ & $<\mathrm{MDL}$ & $<\mathrm{MDL}$ & 0.061 & $<\mathrm{MDL}$ & $<\mathrm{MDL}$ & $<\mathrm{MDL}$ & 0.012 \\
\hline LRM000-s19-1203 & 0.174 & 0.442 & 0.052 & 0.281 & 0.038 & 0.003 & $<\mathrm{MDL}$ & $<\mathrm{MDL}$ & $<\mathrm{MDL}$ & 0.267 & 0.03 & $<\mathrm{MDL}$ & 0.014 & 0.095 \\
\hline LRM050-s19-1203 & 0.059 & 0.149 & 0.016 & 0.083 & 0.012 & $<\mathrm{MDL}$ & $<\mathrm{MDL}$ & $<\mathrm{MDL}$ & $<\mathrm{MDL}$ & 0.128 & $<\mathrm{MDL}$ & $<\mathrm{MDL}$ & 0.012 & 0.038 \\
\hline LRM172-s19-1203 & 0.001 & 0.003 & $<\mathrm{MDL}$ & 0.002 & $<\mathrm{MDL}$ & $<\mathrm{MDL}$ & $<\mathrm{MDL}$ & $<\mathrm{MDL}$ & $<\mathrm{MDL}$ & 0.044 & $<\mathrm{MDL}$ & $<\mathrm{MDL}$ & $<\mathrm{MDL}$ & 0.013 \\
\hline \multicolumn{15}{|l|}{ LRM000-s19-1211 } \\
\hline \multicolumn{15}{|l|}{ LRM050-s19-1211 } \\
\hline \multicolumn{15}{|l|}{ LRM172-s19-1211 } \\
\hline \multicolumn{15}{|l|}{ LRMSHS-s19-1211 } \\
\hline LRM000-s19-1218 & 0.079 & 0.227 & 0.026 & 0.137 & 0.018 & 0.001 & $<\mathrm{MDL}$ & $<\mathrm{MDL}$ & $<\mathrm{MDL}$ & 0.165 & 0.01 & $<\mathrm{MDL}$ & $<\mathrm{MDL}$ & 0.079 \\
\hline LRM050-s19-1218 & 0.015 & 0.04 & 0.004 & 0.021 & 0.003 & $<\mathrm{MDL}$ & $<\mathrm{MDL}$ & $<\mathrm{MDL}$ & $<\mathrm{MDL}$ & 0.061 & $<\mathrm{MDL}$ & $<\mathrm{MDL}$ & $<\mathrm{MDL}$ & 0.05 \\
\hline LRM172-s19-1218 & 0.002 & 0.005 & $<\mathrm{MDL}$ & 0.003 & $<\mathrm{MDL}$ & $<\mathrm{MDL}$ & $<\mathrm{MDL}$ & $<\mathrm{MDL}$ & $<\mathrm{MDL}$ & 0.018 & 0.01 & $<\mathrm{MDL}$ & $<\mathrm{MDL}$ & 0.039 \\
\hline LRMSHS-d19-1218 & 0.001 & 0.004 & $<\mathrm{MDL}$ & 0.003 & $<\mathrm{MDL}$ & $<\mathrm{MDL}$ & $<\mathrm{MDL}$ & $<\mathrm{MDL}$ & $<\mathrm{MDL}$ & 0.002 & 0.02 & $<\mathrm{MDL}$ & 0.002 & 0.682 \\
\hline LRMSHS-s19-1218 & 0.002 & 0.004 & $<\mathrm{MDL}$ & 0.004 & $<\mathrm{MDL}$ & 0.001 & $<\mathrm{MDL}$ & $<\mathrm{MDL}$ & $<\mathrm{MDL}$ & 0.002 & 0.01 & $<\mathrm{MDL}$ & 0.002 & 0.687 \\
\hline LRM000-s20-0102 & 0.075 & 0.21 & 0.023 & 0.125 & 0.018 & $<\mathrm{MDL}$ & $<\mathrm{MDL}$ & $<\mathrm{MDL}$ & $<\mathrm{MDL}$ & 0.194 & 0.03 & $<\mathrm{MDL}$ & $<\mathrm{MDL}$ & 0.061 \\
\hline LRM050-s20-0102 & 0.015 & 0.044 & 0.004 & 0.021 & 0.003 & $<\mathrm{MDL}$ & $<\mathrm{MDL}$ & $<\mathrm{MDL}$ & $<\mathrm{MDL}$ & 0.048 & $<\mathrm{MDL}$ & $<\mathrm{MDL}$ & $<\mathrm{MDL}$ & 0.033 \\
\hline LRM172-s20-0102 & $<\mathrm{MDL}$ & 0.002 & $<\mathrm{MDL}$ & 0.001 & $<\mathrm{MDL}$ & $<\mathrm{MDL}$ & $<\mathrm{MDL}$ & $<\mathrm{MDL}$ & $<\mathrm{MDL}$ & 0.042 & $<\mathrm{MDL}$ & $<\mathrm{MDL}$ & $<\mathrm{MDL}$ & 0.032 \\
\hline
\end{tabular}

Blank cells indiate no data collected

MDL $=$ Method Detection Limit

$<\mathrm{MDL}=$ parameter not detecteble above the method detection limit 


\begin{tabular}{|c|c|c|c|c|c|c|c|c|c|c|c|c|c|c|}
\hline Tracking ID & $\begin{array}{r}\mathrm{Ho} \\
\mathrm{ug} / \mathrm{L}\end{array}$ & $\begin{array}{r}\mathbf{E r} \\
\mathrm{ug} / \mathrm{L}\end{array}$ & $\underset{\text { ug } / \mathrm{L}}{\mathbf{T m}}$ & $\begin{array}{r}\mathbf{Y b} \\
\mathbf{u g} / \mathrm{L}\end{array}$ & $\begin{array}{r}\mathrm{Lu} \\
\mathbf{u g} / \mathrm{L}\end{array}$ & $\begin{array}{r}\mathrm{Hf} \\
\mathrm{ug} / \mathrm{L}\end{array}$ & $\begin{array}{r}\text { Ta } \\
\text { ug/L }\end{array}$ & $\begin{array}{r}W \\
\text { ug/L }\end{array}$ & $\begin{array}{r}\mathrm{Hg} \\
\mathrm{ug} / \mathrm{L}\end{array}$ & $\begin{array}{r}\mathrm{Tl} \\
\mathrm{ug} / \mathrm{L}\end{array}$ & $\begin{array}{r}\mathrm{Pb} \\
\mathrm{ug} / \mathrm{L}\end{array}$ & $\begin{array}{r}\mathrm{Bi} \\
\mathrm{ug} / \mathrm{L}\end{array}$ & $\begin{array}{r}\text { Th } \\
\text { ug/L }\end{array}$ & $\begin{array}{r}\mathrm{U} \\
\mathrm{ug} / \mathrm{L}\end{array}$ \\
\hline MDL & 0.001 & 0.001 & 0.001 & 0.001 & 0.001 & 0.001 & 0.001 & 0.02 & 0.2 & 0.001 & 0.01 & 0.3 & 0.001 & 0.001 \\
\hline LRMSHS-s20-0102 & $<\mathrm{MDL}$ & 0.004 & $<\mathrm{MDL}$ & 0.002 & $<\mathrm{MDL}$ & $<\mathrm{MDL}$ & $<\mathrm{MDL}$ & $<\mathrm{MDL}$ & $<\mathrm{MDL}$ & 0.002 & 0.02 & $<\mathrm{MDL}$ & $<\mathrm{MDL}$ & 1.59 \\
\hline LRM000-s20-0119 & 0.04 & 0.113 & 0.012 & 0.064 & 0.01 & $<\mathrm{MDL}$ & $<\mathrm{MDL}$ & $<\mathrm{MDL}$ & $<\mathrm{MDL}$ & 0.153 & 0.02 & $<\mathrm{MDL}$ & $<\mathrm{MDL}$ & 0.038 \\
\hline LRM050-s20-0119 & 0.011 & 0.032 & 0.003 & 0.016 & 0.002 & $<\mathrm{MDL}$ & $<\mathrm{MDL}$ & $<\mathrm{MDL}$ & $<\mathrm{MDL}$ & 0.063 & $<\mathrm{MDL}$ & $<\mathrm{MDL}$ & $<\mathrm{MDL}$ & 0.034 \\
\hline LRM172-s20-0119 & $<\mathrm{MDL}$ & 0.002 & $<\mathrm{MDL}$ & 0.002 & $<\mathrm{MDL}$ & $<\mathrm{MDL}$ & $<\mathrm{MDL}$ & $<\mathrm{MDL}$ & $<\mathrm{MDL}$ & 0.015 & $<\mathrm{MDL}$ & $<\mathrm{MDL}$ & $<\mathrm{MDL}$ & 0.035 \\
\hline LRMSHS-s20-0119 & 0.002 & 0.005 & $<\mathrm{MDL}$ & 0.004 & $<\mathrm{MDL}$ & $<\mathrm{MDL}$ & $<\mathrm{MDL}$ & $<\mathrm{MDL}$ & $<\mathrm{MDL}$ & 0.002 & 0.02 & $<\mathrm{MDL}$ & 0.004 & 1.16 \\
\hline LRM000-s20-0202 & 0.047 & 0.117 & 0.014 & 0.074 & 0.011 & $<\mathrm{MDL}$ & $<\mathrm{MDL}$ & $<\mathrm{MDL}$ & $<\mathrm{MDL}$ & 0.19 & $<\mathrm{MDL}$ & $<\mathrm{MDL}$ & $<\mathrm{MDL}$ & 0.037 \\
\hline LRM050-s20-0202 & 0.011 & 0.027 & 0.003 & 0.015 & 0.002 & $<\mathrm{MDL}$ & $<\mathrm{MDL}$ & $<\mathrm{MDL}$ & $<\mathrm{MDL}$ & 0.039 & 0.26 & $<\mathrm{MDL}$ & 0.001 & 0.031 \\
\hline LRM172-s20-0202 & $<\mathrm{MDL}$ & 0.002 & $<\mathrm{MDL}$ & 0.001 & $<\mathrm{MDL}$ & $<\mathrm{MDL}$ & $<\mathrm{MDL}$ & $<\mathrm{MDL}$ & $<\mathrm{MDL}$ & 0.023 & $<\mathrm{MDL}$ & $<\mathrm{MDL}$ & $<\mathrm{MDL}$ & 0.035 \\
\hline LRMSHS-s20-0202 & 0.001 & 0.003 & $<\mathrm{MDL}$ & 0.002 & $<\mathrm{MDL}$ & $<\mathrm{MDL}$ & $<\mathrm{MDL}$ & $<\mathrm{MDL}$ & $<\mathrm{MDL}$ & 0.002 & $<\mathrm{MDL}$ & $<\mathrm{MDL}$ & 0.001 & 1.62 \\
\hline LRM000-s20-0216 & 0.03 & 0.077 & 0.009 & 0.046 & 0.007 & $<\mathrm{MDL}$ & $<\mathrm{MDL}$ & $<\mathrm{MDL}$ & $<\mathrm{MDL}$ & 0.173 & $<\mathrm{MDL}$ & $<\mathrm{MDL}$ & $<\mathrm{MDL}$ & 0.049 \\
\hline LRM050-s20-0216 & 0.012 & 0.029 & 0.003 & 0.016 & 0.002 & $<\mathrm{MDL}$ & $<\mathrm{MDL}$ & $<\mathrm{MDL}$ & $<\mathrm{MDL}$ & 0.041 & $<\mathrm{MDL}$ & $<\mathrm{MDL}$ & $<\mathrm{MDL}$ & 0.035 \\
\hline LRM172-s20-0216 & 0.001 & 0.003 & $<\mathrm{MDL}$ & 0.002 & $<\mathrm{MDL}$ & $<\mathrm{MDL}$ & $<\mathrm{MDL}$ & $<\mathrm{MDL}$ & $<\mathrm{MDL}$ & 0.022 & $<\mathrm{MDL}$ & $<\mathrm{MDL}$ & $<\mathrm{MDL}$ & 0.037 \\
\hline LRMSHS-s20-0216 & $<\mathrm{MDL}$ & 0.003 & $<\mathrm{MDL}$ & 0.002 & $<\mathrm{MDL}$ & $<\mathrm{MDL}$ & $<\mathrm{MDL}$ & $<\mathrm{MDL}$ & $<\mathrm{MDL}$ & 0.002 & $<\mathrm{MDL}$ & $<\mathrm{MDL}$ & $<\mathrm{MDL}$ & 1.45 \\
\hline LRM000-s20-0229 & 0.022 & 0.055 & 0.006 & 0.033 & 0.005 & $<\mathrm{MDL}$ & $<\mathrm{MDL}$ & $<\mathrm{MDL}$ & $<\mathrm{MDL}$ & 0.195 & $<\mathrm{MDL}$ & $<\mathrm{MDL}$ & $<$ MDL & 0.039 \\
\hline LRM050-s20-0229 & 0.016 & 0.038 & 0.004 & 0.02 & 0.003 & $<\mathrm{MDL}$ & $<\mathrm{MDL}$ & $<\mathrm{MDL}$ & $<\mathrm{MDL}$ & 0.078 & $<\mathrm{MDL}$ & $<\mathrm{MDL}$ & $<\mathrm{MDL}$ & 0.045 \\
\hline LRM172-s20-0229 & 0.002 & 0.006 & $<\mathrm{MDL}$ & 0.003 & $<\mathrm{MDL}$ & $<\mathrm{MDL}$ & $<\mathrm{MDL}$ & $<\mathrm{MDL}$ & $<\mathrm{MDL}$ & 0.049 & $<\mathrm{MDL}$ & $<\mathrm{MDL}$ & 0.001 & 0.047 \\
\hline LRMSHS-s20-0229 & $<\mathrm{MDL}$ & 0.002 & $<\mathrm{MDL}$ & 0.002 & $<\mathrm{MDL}$ & $<\mathrm{MDL}$ & $<\mathrm{MDL}$ & $<\mathrm{MDL}$ & $<\mathrm{MDL}$ & 0.002 & $<\mathrm{MDL}$ & $<\mathrm{MDL}$ & $<\mathrm{MDL}$ & 1.5 \\
\hline \multicolumn{15}{|l|}{ LRM000-s20-0314 } \\
\hline \multicolumn{15}{|l|}{ LRM050-s20-0314 } \\
\hline \multicolumn{15}{|l|}{ LRM172-s20-0314 } \\
\hline LRMSHS-s20-0314 & & & & & & & & & & & & & & \\
\hline
\end{tabular}

Blank cells indiate no data collected

MDL $=$ Method Detection Limit

$<\mathrm{MDL}=$ parameter not detecteble above the method detection limit 
Table A-1: Meter, ICP-MS, IC Data

\begin{tabular}{|c|c|c|c|c|}
\hline Tracking ID & $\begin{array}{r}\operatorname{Avg} \text { Of } \mathrm{CO}_{2} \\
\mathrm{~g} / \mathrm{L}\end{array}$ & $\begin{array}{r}\text { StDev Of } \mathrm{CO}_{2} \\
\mathrm{~g} / \mathrm{L}\end{array}$ & $\begin{array}{r}\text { Avg Of DIC } \\
\mathrm{mM}\end{array}$ & $\begin{array}{r}\text { StDev Of DIC } \\
\mathrm{mM}\end{array}$ \\
\hline MDL & $6.16 \mathrm{E}-03$ & -- & $1.4-1.6$ & - \\
\hline LRM000-s19-1018 & 0.23 & 0.00 & & \\
\hline LRM050-s19-1018 & 0.03 & 0.00 & 1.08 & 0.10 \\
\hline LRM172-s19-1018 & 0.00 & 0.00 & 0.37 & 0.04 \\
\hline LRM000-s19-1024 & 0.23 & 0.00 & & \\
\hline LRM050-s19-1024 & 0.03 & 0.00 & 1.13 & 0.04 \\
\hline LRM172-s19-1024 & 0.00 & 0.00 & 0.35 & 0.01 \\
\hline LRM000-s19-1102 & 0.23 & 0.00 & & \\
\hline LRM050-s19-1102 & 0.03 & 0.00 & 1.07 & 0.03 \\
\hline LRM172-s19-1102 & 0.00 & 0.00 & 0.35 & 0.06 \\
\hline LRM000-s19-1110 & 0.23 & 0.00 & & \\
\hline LRM050-s19-1110 & 0.03 & 0.00 & 0.86 & 0.03 \\
\hline LRM172-s19-1110 & 0.00 & 0.00 & 0.27 & 0.06 \\
\hline LRM000-s19-1118 & 0.22 & 0.00 & & \\
\hline LRM050-s19-1118 & 0.02 & 0.00 & 0.78 & 0.04 \\
\hline LRM172-s19-1118 & 0.00 & 0.00 & 0.24 & 0.02 \\
\hline LRM000-s19-1203 & 0.22 & & & \\
\hline LRM050-s19-1203 & 0.02 & 0.00 & 0.59 & 0.01 \\
\hline LRM172-s19-1203 & -0.01 & 0.00 & 0.18 & 0.01 \\
\hline LRM000-s19-1211 & 0.21 & 0.00 & & \\
\hline LRM050-s19-1211 & 0.02 & 0.00 & 0.85 & 0.07 \\
\hline LRM172-s19-1211 & -0.01 & & 0.46 & 0.03 \\
\hline LRMSHS-s19-1211 & 0.00 & 0.00 & 3.58 & 0.04 \\
\hline LRM000-s19-1218 & 0.14 & 0.00 & & \\
\hline LRM050-s19-1218 & 0.02 & 0.00 & 1.10 & 0.03 \\
\hline LRM172-s19-1218 & 0.00 & & 0.71 & 0.01 \\
\hline \multicolumn{5}{|l|}{ LRMSHS-d19-1218 } \\
\hline LRMSHS-s19-1218 & 0.00 & 0.00 & 3.09 & 0.04 \\
\hline LRM000-s20-0102 & 0.18 & 0.00 & & \\
\hline LRM050-s20-0102 & 0.02 & 0.00 & 0.81 & 0.05 \\
\hline LRM172-s20-0102 & 0.00 & & 0.50 & 0.04 \\
\hline
\end{tabular}

Blank cells indiate no data collected

MDL $=$ Method Detection Limit

$<\mathrm{MDL}=$ parameter not detecteble above the method detection limit 
Table A-1: Meter, ICP-MS, IC Data

\begin{tabular}{|c|c|c|c|c|}
\hline Tracking ID & $\begin{array}{r}\text { Avg Of } \mathrm{CO}_{2} \\
\mathrm{~g} / \mathrm{L}\end{array}$ & $\begin{array}{r}\text { StDev Of } \mathrm{CO}_{2} \\
\mathrm{~g} / \mathrm{L}\end{array}$ & $\begin{array}{r}\text { Avg Of DIC } \\
\mathrm{mM}\end{array}$ & $\begin{array}{r}\text { StDev Of DIC } \\
\mathrm{mM}\end{array}$ \\
\hline MDL & $6.16 \mathrm{E}-03$ & -- & $1.4-1.6$ & - \\
\hline LRMSHS-s20-0102 & -0.01 & & 4.91 & 0.10 \\
\hline LRM000-s20-0119 & 0.17 & 0.00 & & \\
\hline LRM050-s20-0119 & 0.02 & 0.00 & 1.02 & 0.01 \\
\hline LRM172-s20-0119 & 0.00 & & 0.64 & 0.06 \\
\hline LRMSHS-s20-0119 & 0.00 & & 4.20 & 0.02 \\
\hline LRM000-s20-0202 & 0.19 & 0.00 & & \\
\hline LRM050-s20-0202 & 0.02 & 0.00 & 1.04 & 0.06 \\
\hline LRM172-s20-0202 & & & 0.63 & 0.05 \\
\hline LRMSHS-s20-0202 & & & 5.43 & 0.02 \\
\hline LRM000-s20-0216 & 0.20 & 0.00 & 4.96 & 0.08 \\
\hline LRM050-s20-0216 & 0.04 & 0.00 & 1.63 & 0.04 \\
\hline LRM172-s20-0216 & & & 0.86 & 0.06 \\
\hline LRMSHS-s20-0216 & & & 4.69 & 0.05 \\
\hline LRM000-s20-0229 & 0.23 & 0.00 & 6.18 & 0.10 \\
\hline LRM050-s20-0229 & 0.04 & 0.00 & 1.85 & 0.02 \\
\hline LRM172-s20-0229 & & & 0.88 & 0.06 \\
\hline LRMSHS-s20-0229 & & & 4.72 & 0.07 \\
\hline LRM000-s20-0314 & 0.20 & 0.01 & 5.27 & 0.09 \\
\hline LRM050-s20-0314 & 0.04 & 0.00 & 1.94 & 0.01 \\
\hline LRM172-s20-0314 & & & 1.06 & 0.01 \\
\hline LRMSHS-s20-0314 & & & 5.02 & 0.00 \\
\hline
\end{tabular}

Blank cells indiate no data collected

MDL $=$ Method Detection Limit

$<\mathrm{MDL}=$ parameter not detecteble above the method detection limit 
Table A-2: Discharge Data

\begin{tabular}{|c|c|c|c|c|c|}
\hline Tracking ID & Date & Time & $\mathbf{n}$ & $\begin{array}{r}Q \text { mean } \\
\mathrm{m}^{3} / \mathrm{sec}\end{array}$ & $\begin{array}{r}\text { Q SD } \\
\mathrm{m}^{3} / \mathrm{sec} \\
\end{array}$ \\
\hline LRM010-s19-1018 & $10 / 18 / 2019$ & $14: 40$ & 3 & $2.05 \mathrm{E}-03$ & $0.00 \mathrm{E}+00$ \\
\hline LRM010-s19-1024 & $10 / 24 / 2019$ & $15: 45$ & 3 & $1.73 \mathrm{E}-03$ & $0.00 \mathrm{E}+00$ \\
\hline LRM010-s19-1102 & $11 / 2 / 2019$ & $11: 20$ & 6 & $1.45 \mathrm{E}-03$ & $7.44 \mathrm{E}-05$ \\
\hline LRM010-s19-1110 & $11 / 10 / 2019$ & $11: 25$ & 3 & $1.41 \mathrm{E}-03$ & $3.46 \mathrm{E}-05$ \\
\hline LRM010-s19-1118 & $11 / 18 / 2019$ & $14: 10$ & 3 & $1.48 \mathrm{E}-03$ & $0.00 \mathrm{E}+00$ \\
\hline LRM010-s19-1203 & $12 / 3 / 2019$ & $14: 35$ & 3 & $1.34 \mathrm{E}-03$ & $2.96 \mathrm{E}-05$ \\
\hline LRM010-s19-1211 & $12 / 11 / 2019$ & $14: 55$ & 3 & $1.31 \mathrm{E}-03$ & $0.00 \mathrm{E}+00$ \\
\hline LRM010-s19-1218 & $12 / 18 / 2019$ & $15: 50$ & 3 & $3.97 \mathrm{E}-03$ & $0.00 \mathrm{E}+00$ \\
\hline LRM010-s20-0102 & $1 / 2 / 2020$ & $13: 30$ & 3 & $2.13 \mathrm{E}-03$ & $2.82 \mathrm{E}-05$ \\
\hline LRM010-s20-0119 & $1 / 19 / 2020$ & $15: 10$ & 3 & $2.81 \mathrm{E}-03$ & $0.00 \mathrm{E}+00$ \\
\hline LRM010-s20-0202 & $2 / 2 / 2020$ & $14: 25$ & 3 & $3.21 \mathrm{E}-03$ & $0.00 \mathrm{E}+00$ \\
\hline LRM010-s20-0216 & $2 / 16 / 2020$ & $12: 55$ & 3 & 8.31E-03 & $1.08 \mathrm{E}-04$ \\
\hline LRM010-s20-0229 & $2 / 29 / 2020$ & $11: 40$ & 3 & $9.80 \mathrm{E}-03$ & $0.00 \mathrm{E}+00$ \\
\hline LRM010-s20-0314 & $3 / 14 / 2020$ & 12:05 & 3 & $7.13 \mathrm{E}-03$ & $4.02 \mathrm{E}-05$ \\
\hline
\end{tabular}

$\mathrm{Q}=$ Discharge

$\mathrm{SD}=$ Standard Deviation 
Table A-3: $\delta^{2} \mathrm{H}$ and $\delta^{18} \mathrm{O}$ Data

\begin{tabular}{|c|c|c|c|c|}
\hline Tracking ID & Date & Time & $\begin{array}{r}\delta^{2} \mathbf{H} \\
\% \text { VSMOW } \\
\end{array}$ & $\begin{array}{r}\delta^{18} \mathrm{O} \\
\% \text { VSMOW } \\
\end{array}$ \\
\hline LRM000-s19-1018 & $10 / 18 / 2019$ & $15: 20$ & -49.85 & -7.93 \\
\hline LRM000-s19-1018 & $10 / 18 / 2019$ & $15: 20$ & -49.59 & -7.91 \\
\hline LRM050-s19-1018 & $10 / 18 / 2019$ & $13: 55$ & -49.38 & -7.67 \\
\hline LRM050-s19-1018 & $10 / 18 / 2019$ & $13: 55$ & -49.38 & -7.69 \\
\hline LRM172-s19-1018 & $10 / 18 / 2019$ & $13: 15$ & -50.10 & -7.77 \\
\hline LRM172-s19-1018 & $10 / 18 / 2019$ & $13: 15$ & -49.55 & -7.73 \\
\hline LRM000-s19-1102 & $11 / 2 / 2019$ & $11: 55$ & -49.80 & -7.89 \\
\hline LRM000-s19-1102 & $11 / 2 / 2019$ & $11: 55$ & -49.64 & -7.89 \\
\hline LRM050-s19-1102 & $11 / 2 / 2019$ & $10: 30$ & -49.44 & -7.81 \\
\hline LRM050-s19-1102 & $11 / 2 / 2019$ & $10: 30$ & -49.31 & -7.76 \\
\hline LRM172-s19-1102 & $11 / 2 / 2019$ & $9: 45$ & -49.44 & -7.69 \\
\hline LRM172-s19-1102 & $11 / 2 / 2019$ & $9: 45$ & -49.15 & -7.71 \\
\hline LRM000-s19-1118 & $11 / 18 / 2019$ & $14: 30$ & -49.82 & -7.86 \\
\hline LRM000-s19-1118 & $11 / 18 / 2019$ & $14: 30$ & -49.81 & -7.85 \\
\hline LRM050-s19-1118 & $11 / 18 / 2019$ & $13: 30$ & -49.34 & -7.78 \\
\hline LRM050-s19-1118 & $11 / 18 / 2019$ & $13: 30$ & -49.17 & -7.75 \\
\hline LRM172-s19-1118 & $11 / 18 / 2019$ & 13:00 & -49.54 & -7.48 \\
\hline LRM172-s19-1118 & $11 / 18 / 2019$ & 13:00 & -49.51 & -7.54 \\
\hline LRM000-s19-1203 & $12 / 3 / 2019$ & $15: 05$ & -50.01 & -7.82 \\
\hline LRM000-s19-1203 & $12 / 3 / 2019$ & $15: 05$ & -49.86 & -7.86 \\
\hline LRM050-s19-1203 & $12 / 3 / 2019$ & $13: 55$ & -49.32 & -7.71 \\
\hline LRM050-s19-1203 & $12 / 3 / 2019$ & $13: 55$ & -49.31 & -7.70 \\
\hline LRM172-s19-1203 & $12 / 3 / 2019$ & $13: 15$ & -49.02 & -7.65 \\
\hline LRM172-s19-1203 & $12 / 3 / 2019$ & $13: 15$ & -48.97 & -7.65 \\
\hline LRM000-s19-1218 & $12 / 18 / 2019$ & $16: 00$ & -49.66 & -7.76 \\
\hline LRM000-s19-1218 & $12 / 18 / 2019$ & $16: 00$ & -49.58 & -7.84 \\
\hline LRM050-s19-1218 & $12 / 18 / 2019$ & $14: 50$ & -49.93 & -7.95 \\
\hline LRM050-s19-1218 & $12 / 18 / 2019$ & $14: 50$ & -49.71 & -7.84 \\
\hline LRM172-s19-1218 & $12 / 18 / 2019$ & $14: 15$ & -51.59 & -7.95 \\
\hline LRM172-s19-1218 & $12 / 18 / 2019$ & $14: 15$ & -51.54 & -7.94 \\
\hline LRMSHS-d19-1218 & $12 / 18 / 2019$ & $13: 30$ & -52.37 & -8.17 \\
\hline LRMSHS-d19-1218 & $12 / 18 / 2019$ & $13: 30$ & -52.27 & -8.27 \\
\hline LRMSHS-s19-1218 & $12 / 18 / 2019$ & $13: 25$ & -52.40 & -8.20 \\
\hline LRMSHS-s19-1218 & $12 / 18 / 2019$ & $13: 25$ & -52.32 & -8.06 \\
\hline LRM000-s20-0102 & $1 / 2 / 2020$ & $14: 05$ & -49.46 & -8.18 \\
\hline LRM000-s20-0102 & $1 / 2 / 2020$ & $14: 05$ & -49.44 & -8.16 \\
\hline LRM050-s20-0102 & $1 / 2 / 2020$ & $12: 40$ & -50.30 & -8.06 \\
\hline LRM050-s20-0102 & $1 / 2 / 2020$ & $12: 40$ & -50.17 & -8.14 \\
\hline LRM172-s20-0102 & $1 / 2 / 2020$ & $12: 15$ & -49.73 & -7.90 \\
\hline LRM172-s20-0102 & $1 / 2 / 2020$ & $12: 15$ & -49.34 & -7.91 \\
\hline LRMSHS-s20-0102 & $1 / 2 / 2020$ & $11: 20$ & -49.84 & -7.84 \\
\hline LRMSHS-s20-0102 & $1 / 2 / 2020$ & $11: 20$ & -49.38 & -7.89 \\
\hline LRM000-s20-0119 & $1 / 19 / 2020$ & $15: 55$ & -48.75 & -7.73 \\
\hline LRM000-s20-0119 & $1 / 19 / 2020$ & $15: 55$ & -48.66 & -7.81 \\
\hline
\end{tabular}


Table A-3: $\delta^{2} \mathrm{H}$ and $\delta^{18} \mathrm{O}$ Data

\begin{tabular}{|l|c|c|r|r|}
\hline Tracking ID & Date & Time & $\begin{array}{r}\boldsymbol{\delta}^{2} \mathbf{H} \\
\text { \%o VSMOW }\end{array}$ & $\begin{array}{r}\boldsymbol{\delta}^{\mathbf{1 8}} \mathbf{O} \\
\text { \%o VSMOW }\end{array}$ \\
\hline LRM050-s20-0119 & $1 / 19 / 2020$ & $14: 30$ & -49.46 & -8.22 \\
\hline LRM050-s20-0119 & $1 / 19 / 2020$ & $14: 30$ & -49.42 & -8.08 \\
\hline LRM172-s20-0119 & $1 / 19 / 2020$ & $13: 45$ & -49.58 & -7.86 \\
\hline LRM172-s20-0119 & $1 / 19 / 2020$ & $13: 45$ & -49.37 & -7.95 \\
\hline LRMSHS-s20-0119 & $1 / 19 / 2020$ & $12: 55$ & -50.17 & -8.16 \\
\hline LRMSHS-s20-0119 & $1 / 19 / 2020$ & $12: 55$ & -50.11 & -8.08 \\
\hline LRM000-s20-0202 & $2 / 2 / 2020$ & $15: 00$ & -51.41 & -8.36 \\
\hline LRM000-s20-0202 & $2 / 2 / 2020$ & $15: 00$ & -51.36 & -8.33 \\
\hline LRM050-s20-0202 & $2 / 2 / 2020$ & $13: 45$ & -49.85 & -7.74 \\
\hline LRM050-s20-0202 & $2 / 2 / 2020$ & $13: 45$ & -49.74 & -7.60 \\
\hline LRM172-s20-0202 & $2 / 2 / 2020$ & $13: 05$ & -50.25 & -8.38 \\
\hline LRM172-s20-0202 & $2 / 2 / 2020$ & $13: 05$ & -50.15 & -8.25 \\
\hline LRMSHS-s20-0202 & $2 / 2 / 2020$ & $12: 10$ & -50.13 & -8.57 \\
\hline LRMSHS-s20-0202 & $2 / 2 / 2020$ & $12: 10$ & -50.03 & -8.32 \\
\hline LRM000-s20-0216 & $2 / 16 / 2020$ & $13: 30$ & -49.64 & -7.97 \\
\hline LRM000-s20-0216 & $2 / 16 / 2020$ & $13: 30$ & -49.48 & -7.96 \\
\hline LRM050-s20-0216 & $2 / 16 / 2020$ & $12: 20$ & -50.50 & -7.92 \\
\hline LRM050-s20-0216 & $2 / 16 / 2020$ & $12: 20$ & -50.44 & -8.00 \\
\hline LRM172-s20-0216 & $2 / 16 / 2020$ & $11: 35$ & -50.35 & -8.03 \\
\hline LRM172-s20-0216 & $2 / 16 / 2020$ & $11: 35$ & -50.11 & -7.98 \\
\hline LRMSHS-s20-0216 & $2 / 16 / 2020$ & $10: 50$ & -50.62 & -8.05 \\
\hline LRMSHS-s20-0216 & $2 / 16 / 2020$ & $10: 50$ & -50.56 & -8.04 \\
\hline LRM000-s20-0229 & $2 / 29 / 2020$ & $12: 20$ & -49.71 & -8.12 \\
\hline LRM000-s20-0229 & $2 / 29 / 2020$ & $12: 20$ & -49.63 & -7.96 \\
\hline LRM050-s20-0229 & $2 / 29 / 2020$ & $11: 10$ & -49.99 & -8.03 \\
\hline LRM050-s20-0229 & $2 / 29 / 2020$ & $11: 10$ & -49.73 & -8.05 \\
\hline LRM172-s20-0229 & $2 / 29 / 2020$ & $10: 40$ & -50.04 & -8.09 \\
\hline LRM172-s20-0229 & $2 / 29 / 2020$ & $10: 40$ & -49.89 & -8.00 \\
\hline LRMSHS-s20-0229 & $2 / 29 / 2020$ & $9: 55$ & -50.45 & -8.04 \\
\hline LRMSHS-s20-0229 & $2 / 29 / 2020$ & $9: 55$ & -50.28 & -7.95 \\
\hline
\end{tabular}


Table A-4: $\delta^{13} \mathrm{C}$ Data

\begin{tabular}{|l|c|r|r|l|}
\hline \multicolumn{1}{|c|}{ Tracking ID } & Date & Time & $\begin{array}{r}\boldsymbol{\delta}^{\mathbf{1 3}} \mathbf{C} \\
\text { \%o VPDB }\end{array}$ & Comments \\
\hline LRM000-s19-1018 & $10 / 18 / 2019$ & $15: 20$ & -12.20 & \\
\hline LRM050-s19-1018 & $10 / 18 / 2019$ & $13: 55$ & -6.95 & \\
\hline LRM172-s19-1018 & $10 / 18 / 2019$ & $13: 15$ & -4.77 & "very low amplitudes so their values are not reliable" \\
\hline LRM000-s19-1102 & $11 / 2 / 2019$ & $11: 55$ & -12.13 & \\
\hline LRM050-s19-1102 & $11 / 2 / 2019$ & $10: 30$ & -7.47 & \\
\hline LRM172-s19-1102 & $11 / 2 / 2019$ & $9: 45$ & -5.03 & \\
\hline LRM000-s19-1118 & $11 / 18 / 2019$ & $14: 30$ & -12.17 & \\
\hline LRM050-s19-1118 & $11 / 18 / 2019$ & $13: 30$ & -7.58 & \\
\hline LRM172-s19-1118 & $11 / 18 / 2019$ & $13: 00$ & -4.77 & "very low amplitudes so their values are not reliable" \\
\hline LRM000-s19-1203 & $12 / 3 / 2019$ & $15: 05$ & -12.36 & \\
\hline LRM050-s19-1203 & $12 / 3 / 2019$ & $13: 55$ & -6.56 & \\
\hline LRM172-s19-1203 & $12 / 3 / 2019$ & $13: 15$ & -4.79 & "very low amplitudes so their values are not reliable" \\
\hline LRM000-s19-1218 & $12 / 18 / 2019$ & $16: 00$ & -11.23 & \\
\hline LRM050-s19-1218 & $12 / 18 / 2019$ & $14: 50$ & -6.05 & \\
\hline LRM172-s19-1218 & $12 / 18 / 2019$ & $14: 15$ & -5.50 & \\
\hline LRMSHS-d19-1218 & $12 / 18 / 2019$ & $13: 30$ & -10.53 & \\
\hline LRMSHS-s19-1218 & $12 / 18 / 2019$ & $13: 25$ & -10.53 & \\
\hline LRM000-s20-0102 & $1 / 2 / 2020$ & $14: 05$ & -11.62 & \\
\hline LRM050-s20-0102 & $1 / 2 / 2020$ & $12: 40$ & -5.81 & \\
\hline LRM172-s20-0102 & $1 / 2 / 2020$ & $12: 15$ & -4.28 & \\
\hline LRMSHS-s20-0102 & $1 / 2 / 2020$ & $11: 20$ & -10.14 & \\
\hline
\end{tabular}


Appendix B: Complete Correlation Matrices 
Table B-1: LRM-000 - All Samples

\begin{tabular}{|c|c|c|c|c|c|c|c|c|c|c|c|c|c|}
\hline & & Temp & $\mathrm{pH}$ & $\mathrm{SC}$ & DO & $\mathrm{SO}_{4}$ & $\mathrm{Mg}$ & $\mathrm{Al}$ & $\mathrm{Ca}$ & $\mathrm{Mn}$ & $\mathrm{Fe}$ & DIC & YREE \\
\hline \multirow{2}{*}{$\mathrm{pH}$} & $\mathrm{R}$ & -0.326 & & & & & & & & & & & \\
\hline & $\mathrm{p}$ & 0.186 & & & & & & & & & & & \\
\hline \multirow{2}{*}{ SC } & $\mathrm{R}$ & 0.727 & 0.085 & & & & & & & & & & \\
\hline & $\mathrm{p}$ & 0.001 & 0.738 & & & & & & & & & & \\
\hline \multirow{2}{*}{ DO } & $\mathrm{R}$ & -0.190 & 0.130 & 0.122 & & & & & & & & & \\
\hline & $\mathrm{p}$ & 0.450 & 0.606 & 0.630 & & & & & & & & & \\
\hline \multirow{2}{*}{$\mathrm{SO}_{4}$} & $\mathrm{R}$ & 0.805 & -0.387 & 0.745 & 0.264 & & & & & & & & \\
\hline & $\mathrm{p}$ & 0.001 & 0.171 & 0.002 & 0.361 & & & & & & & & \\
\hline \multirow{2}{*}{$\mathrm{Mg}$} & $\mathrm{R}$ & 0.271 & 0.480 & 0.655 & 0.139 & 0.451 & & & & & & & \\
\hline & $\mathrm{p}$ & 0.349 & 0.083 & 0.011 & 0.636 & 0.105 & & & & & & & \\
\hline \multirow{2}{*}{$\mathrm{Al}$} & $\mathrm{R}$ & 0.639 & -0.886 & 0.241 & 0.168 & 0.622 & -0.312 & & & & & & \\
\hline & $\mathrm{p}$ & 0.014 & 0.000 & 0.406 & 0.566 & 0.017 & 0.278 & & & & & & \\
\hline \multirow{2}{*}{$\mathrm{Ca}$} & $\mathrm{R}$ & 0.330 & 0.554 & 0.669 & 0.261 & 0.432 & 0.900 & -0.248 & & & & & \\
\hline & $\mathrm{p}$ & 0.249 & 0.040 & 0.009 & 0.367 & 0.123 & 0.000 & 0.392 & & & & & \\
\hline \multirow{2}{*}{$\mathrm{Mn}$} & $\mathrm{R}$ & 0.705 & -0.837 & 0.270 & -0.137 & 0.640 & -0.117 & 0.881 & -0.170 & & & & \\
\hline & $\mathrm{p}$ & 0.005 & 0.000 & 0.351 & 0.640 & 0.014 & 0.691 & 0.000 & 0.561 & & & & \\
\hline \multirow{2}{*}{$\mathrm{Fe}$} & $\mathrm{R}$ & 0.696 & -0.788 & 0.382 & 0.187 & 0.657 & -0.208 & 0.963 & -0.108 & 0.837 & & & \\
\hline & $\mathrm{p}$ & 0.006 & 0.001 & 0.178 & 0.522 & 0.011 & 0.477 & 0.000 & 0.713 & 0.000 & & & \\
\hline \multirow{2}{*}{ DIC } & $\mathrm{R}$ & 0.728 & 0.220 & 0.850 & 0.095 & 0.740 & 0.724 & 0.125 & 0.781 & 0.195 & 0.241 & & \\
\hline & $\mathrm{p}$ & 0.001 & 0.380 & 0.000 & 0.707 & 0.002 & 0.003 & 0.670 & 0.001 & 0.505 & 0.406 & & \\
\hline \multirow{2}{*}{ YREE } & $\mathrm{R}$ & 0.385 & -0.759 & 0.102 & 0.239 & 0.422 & -0.330 & 0.804 & -0.334 & 0.611 & 0.837 & -0.043 & \\
\hline & $\mathrm{p}$ & 0.174 & 0.002 & 0.728 & 0.410 & 0.133 & 0.250 & 0.001 & 0.243 & 0.020 & 0.000 & 0.883 & \\
\hline \multirow{2}{*}{ Q } & $\bar{R}$ & -0.258 & 0.891 & 0.236 & 0.300 & -0.110 & 0.657 & -0.732 & 0.688 & -0.680 & -0.635 & 0.426 & -0.664 \\
\hline & $\mathrm{p}$ & 0.301 & 0.000 & 0.345 & 0.226 & 0.708 & 0.011 & 0.003 & 0.007 & 0.007 & 0.015 & 0.078 & 0.010 \\
\hline
\end{tabular}

Bold \& shaded values indidicate Pearson correlation coefficient $>|0.7|$ or $\mathrm{p}<0.05$

$\mathrm{SC}=$ Specific Conductance

DO $=$ Dissolved Oxygen

DIC = Dissolved Inorganic Carbon

YREE $=$ Yttrium and Rare Earth Elements

$\mathrm{Q}=$ Discharge 
Table B-2: LRM-000 - Diffuse Recharge Domininant Samples

\begin{tabular}{|c|c|c|c|c|c|c|c|c|c|c|c|c|c|}
\hline & & Temp & $\mathrm{pH}$ & $\mathrm{SC}$ & DO & $\mathrm{SO}_{4}$ & $\mathrm{Mg}$ & $\mathrm{Al}$ & $\mathrm{Ca}$ & $\mathrm{Mn}$ & $\mathrm{Fe}$ & DIC & YREE \\
\hline \multirow{2}{*}{$\mathrm{pH}$} & $\mathrm{R}$ & 0.192 & & & & & & & & & & & \\
\hline & $\mathrm{p}$ & 0.649 & & & & & & & & & & & \\
\hline \multirow{2}{*}{ SC } & $\mathrm{R}$ & -0.182 & -0.817 & & & & & & & & & & \\
\hline & $\mathrm{p}$ & 0.667 & 0.013 & & & & & & & & & & \\
\hline \multirow{2}{*}{ DO } & $\mathrm{R}$ & -0.521 & 0.302 & -0.141 & & & & & & & & & \\
\hline & $\mathrm{p}$ & 0.185 & 0.468 & 0.739 & & & & & & & & & \\
\hline \multirow{2}{*}{$\mathrm{SO}_{4}$} & $\mathrm{R}$ & 0.362 & 0.370 & -0.582 & -0.648 & & & & & & & & \\
\hline & $\mathrm{p}$ & 0.481 & 0.471 & 0.226 & 0.164 & & & & & & & & \\
\hline \multirow{2}{*}{$\mathrm{Mg}$} & $\mathrm{R}$ & 0.687 & 0.510 & -0.037 & 0.369 & -0.164 & & & & & & & \\
\hline & $\mathrm{p}$ & 0.132 & 0.301 & 0.945 & 0.471 & 0.757 & & & & & & & \\
\hline \multirow{2}{*}{$\mathrm{Al}$} & $\mathrm{R}$ & 0.562 & 0.380 & 0.115 & 0.495 & -0.302 & 0.983 & & & & & & \\
\hline & $\mathrm{p}$ & 0.246 & 0.457 & 0.828 & 0.319 & 0.560 & 0.000 & & & & & & \\
\hline \multirow{2}{*}{$\mathrm{Ca}$} & $\mathrm{R}$ & 0.638 & 0.395 & -0.003 & 0.226 & -0.091 & 0.869 & 0.870 & & & & & \\
\hline & $\mathrm{p}$ & 0.172 & 0.438 & 0.996 & 0.667 & 0.865 & 0.024 & 0.024 & & & & & \\
\hline \multirow{2}{*}{$\mathrm{Mn}$} & $\mathrm{R}$ & 0.987 & 0.658 & -0.391 & -0.278 & 0.312 & 0.775 & 0.655 & 0.681 & & & & \\
\hline & $\mathrm{p}$ & 0.000 & 0.155 & 0.443 & 0.593 & 0.547 & 0.070 & 0.158 & 0.137 & & & & \\
\hline \multirow{2}{*}{$\mathrm{Fe}$} & $\mathrm{R}$ & -0.150 & 0.074 & 0.314 & 0.913 & -0.607 & 0.594 & 0.710 & 0.584 & -0.030 & & & \\
\hline & $\mathrm{p}$ & 0.777 & 0.889 & 0.545 & 0.011 & 0.201 & 0.214 & 0.114 & 0.224 & 0.955 & & & \\
\hline \multirow{2}{*}{ DIC } & $\mathrm{R}$ & 0.745 & 0.257 & -0.415 & -0.566 & 0.660 & 0.083 & -0.075 & 0.150 & 0.687 & -0.703 & & \\
\hline & $\mathrm{p}$ & 0.034 & 0.539 & 0.307 & 0.144 & 0.154 & 0.875 & 0.888 & 0.776 & 0.131 & 0.120 & & \\
\hline \multirow{2}{*}{ YREE } & $\mathrm{R}$ & -0.694 & 0.074 & -0.034 & 0.805 & -0.394 & -0.106 & -0.017 & -0.201 & -0.577 & 0.597 & -0.845 & \\
\hline & $\mathrm{p}$ & 0.126 & 0.889 & 0.949 & 0.053 & 0.439 & 0.842 & 0.974 & 0.703 & 0.231 & 0.211 & 0.034 & \\
\hline \multirow{2}{*}{ Q } & $\mathrm{R}$ & 0.814 & 0.305 & -0.532 & -0.517 & 0.680 & 0.160 & -0.011 & 0.198 & 0.741 & -0.630 & 0.957 & -0.738 \\
\hline & $\mathrm{p}$ & 0.014 & 0.463 & 0.174 & 0.190 & 0.138 & 0.763 & 0.984 & 0.706 & 0.092 & 0.180 & 0.000 & 0.094 \\
\hline
\end{tabular}

Bold \& shaded values indidicate Pearson correlation coefficient $>|0.7|$ or $p<0.05$

$\mathrm{SC}=$ Specific Conductance

$\mathrm{DO}=$ Dissolved Oxygen

DIC = Dissolved Inorganic Carbon

YREE $=$ Yttrium and Rare Earth Elements

$\mathrm{Q}=$ Discharge 
Table B-3: LRM-000 - Direct Recharge Domininant Samples

\begin{tabular}{|c|c|c|c|c|c|c|c|c|c|c|c|c|c|}
\hline & & Temp & $\mathrm{pH}$ & SC & DO & $\mathrm{SO}_{4}$ & $\mathrm{Mg}$ & $\mathrm{Al}$ & $\mathrm{Ca}$ & $\mathrm{Mn}$ & $\mathrm{Fe}$ & $\overline{D I C}$ & YREE \\
\hline \multirow{2}{*}{$\mathrm{pH}$} & $\mathrm{R}$ & 0.538 & & & & & & & & & & & \\
\hline & $\mathrm{p}$ & 0.109 & & & & & & & & & & & \\
\hline \multirow{2}{*}{$\mathrm{SC}$} & $\mathrm{R}$ & 0.838 & 0.678 & & & & & & & & & & \\
\hline & $\mathrm{p}$ & 0.002 & 0.031 & & & & & & & & & & \\
\hline \multirow{2}{*}{ DO } & $\mathrm{R}$ & -0.304 & 0.261 & 0.152 & & & & & & & & & \\
\hline & $\mathrm{p}$ & 0.393 & 0.466 & 0.675 & & & & & & & & & \\
\hline \multirow{2}{*}{$\mathrm{SO}_{4}$} & $\mathrm{R}$ & 0.580 & 0.412 & 0.878 & 0.296 & & & & & & & & \\
\hline & $\mathrm{p}$ & 0.132 & 0.310 & 0.004 & 0.476 & & & & & & & & \\
\hline \multirow{2}{*}{$\mathrm{Mg}$} & $\mathrm{R}$ & 0.695 & 0.515 & 0.942 & 0.163 & 0.946 & & & & & & & \\
\hline & $\mathrm{p}$ & 0.056 & 0.192 & 0.000 & 0.700 & 0.000 & & & & & & & \\
\hline \multirow{2}{*}{$\mathrm{Al}$} & $\mathrm{R}$ & -0.688 & -0.868 & -0.751 & 0.204 & -0.410 & -0.515 & & & & & & \\
\hline & $\mathrm{p}$ & 0.059 & 0.005 & 0.032 & 0.628 & 0.313 & 0.192 & & & & & & \\
\hline \multirow{2}{*}{$\mathrm{Ca}$} & $\bar{R}$ & 0.701 & 0.776 & 0.957 & 0.294 & 0.864 & 0.920 & -0.654 & & & & & \\
\hline & $\mathrm{p}$ & 0.053 & 0.024 & 0.000 & 0.480 & 0.006 & 0.001 & 0.078 & & & & & \\
\hline \multirow{2}{*}{$\mathrm{Mn}$} & $\bar{R}$ & 0.047 & -0.618 & -0.114 & -0.538 & 0.018 & 0.081 & 0.275 & -0.293 & & & & \\
\hline & $\mathrm{p}$ & 0.912 & 0.103 & 0.788 & 0.169 & 0.967 & 0.849 & 0.510 & 0.481 & & & & \\
\hline \multirow{2}{*}{$\mathrm{Fe}$} & $\bar{R}$ & -0.863 & -0.749 & -0.652 & 0.568 & -0.270 & -0.424 & 0.887 & -0.511 & 0.071 & & & \\
\hline & $\mathrm{p}$ & 0.006 & 0.033 & 0.080 & 0.142 & 0.518 & 0.295 & 0.003 & 0.196 & 0.868 & & & \\
\hline \multirow{2}{*}{ DIC } & $\mathrm{R}$ & 0.768 & 0.773 & 0.936 & 0.111 & 0.787 & 0.877 & -0.778 & 0.947 & -0.235 & -0.688 & & \\
\hline & $\mathrm{p}$ & 0.009 & 0.009 & 0.000 & 0.760 & 0.021 & 0.004 & 0.023 & 0.000 & 0.576 & 0.059 & & \\
\hline \multirow{2}{*}{ YREE } & $\bar{R}$ & -0.751 & -0.886 & -0.766 & 0.257 & -0.413 & -0.523 & 0.991 & -0.665 & 0.286 & 0.924 & -0.805 & \\
\hline & $\mathrm{p}$ & 0.032 & 0.003 & 0.027 & 0.539 & 0.309 & 0.184 & 0.000 & 0.072 & 0.493 & 0.001 & 0.016 & \\
\hline \multirow{2}{*}{ Q } & $\bar{R}$ & 0.316 & 0.842 & 0.669 & 0.442 & 0.624 & 0.697 & -0.690 & 0.838 & -0.452 & -0.445 & 0.810 & -0.691 \\
\hline & $\mathrm{p}$ & 0.374 & 0.002 & 0.034 & 0.201 & 0.098 & 0.055 & 0.058 & 0.009 & 0.261 & 0.269 & 0.004 & 0.058 \\
\hline
\end{tabular}

Bold \& shaded values indidicate Pearson correlation coefficient $>|0.7|$ or $\mathrm{p}<0.05$

$\mathrm{SC}=$ Specific Conductance

DO $=$ Dissolved Oxygen

DIC $=$ Dissolved Inorganic Carbon

YREE $=$ Yttrium and Rare Earth Elements

$\mathrm{Q}=$ Discharge 


\section{Appendix C: YREE Thermodynamic Data Corrections}

The Lawrence-Livermore National Laboratory (LLNL) PHREEQC database was used for geochemical speciation calculations, primarily for its inclusion of YREE data. LLNL version used dated to 8/1/2017. Several discrepancies of YREE complex log K values were noted when compared to literature. These discrepancies were not addressed further in this work but were noted.

Several YREE $\mathrm{SO}_{4}$ complexes had inconsistent signs on their respective log $\mathrm{K}$ values. $\mathrm{SO}_{4}$ YREE complex thermodynamic data were replaced with data from Liu et al. (2017). Replaced $\log \mathrm{K}$ values were summarized below.

Table 16: Log K values for REE-SO $\mathrm{S}_{4}$ complexes from Liu et al. (2017).

\begin{tabular}{lc}
\hline Element & $\begin{array}{c}\text { Log K (forward } \\
\text { reaction) }\end{array}$ \\
\hline $\mathrm{La}$ & 3.61 \\
$\mathrm{Ce}$ & 3.61 \\
$\mathrm{Pr}$ & 3.62 \\
$\mathrm{Nd}$ & 3.60 \\
$\mathrm{Sm}$ & 3.63 \\
$\mathrm{Eu}$ & 3.64 \\
$\mathrm{Gd}$ & 3.61 \\
$\mathrm{~Tb}$ & 3.59 \\
$\mathrm{Dy}$ & 3.57 \\
$\mathrm{Ho}$ & 3.54 \\
$\mathrm{Er}$ & 3.51 \\
$\mathrm{Tm}$ & 3.48 \\
$\mathrm{Yb}$ & 3.46 \\
$\mathrm{Lu}$ & 3.44 \\
\hline
\end{tabular}




\section{Appendix D: Duplicate Sample Results}

Percent difference was calculated for all samples with duplicate pairs to assess the variance of each method and analyte (13).

$$
\% \text { Difference }=\frac{[\text { Sample }]-[\text { Duplicate }]}{[\text { Average }]} \times 100 .
$$

Equation 13

Where [sample] is the concentration of the sample, [duplicate] is the concentration of the duplicate, and [average] is the average concentration of the sample and duplicate, where all concentrations are in the same unit.

The largest percent differences observed during this study generally occurred at low $(<1)$ concentration values. For graphical clarity, concentrations were plotted as the numerical value, independent of units (i.e. $1.54 \mathrm{mg} / \mathrm{L}$ and $1.54 \mu \mathrm{g} / \mathrm{L}$ would both be plotted as 1.54 ). Higher concentration elements with large percent differences (e.g. Ba, $\mathrm{Zn}$ ) were not used for detailed chemical analyses or interpretations.

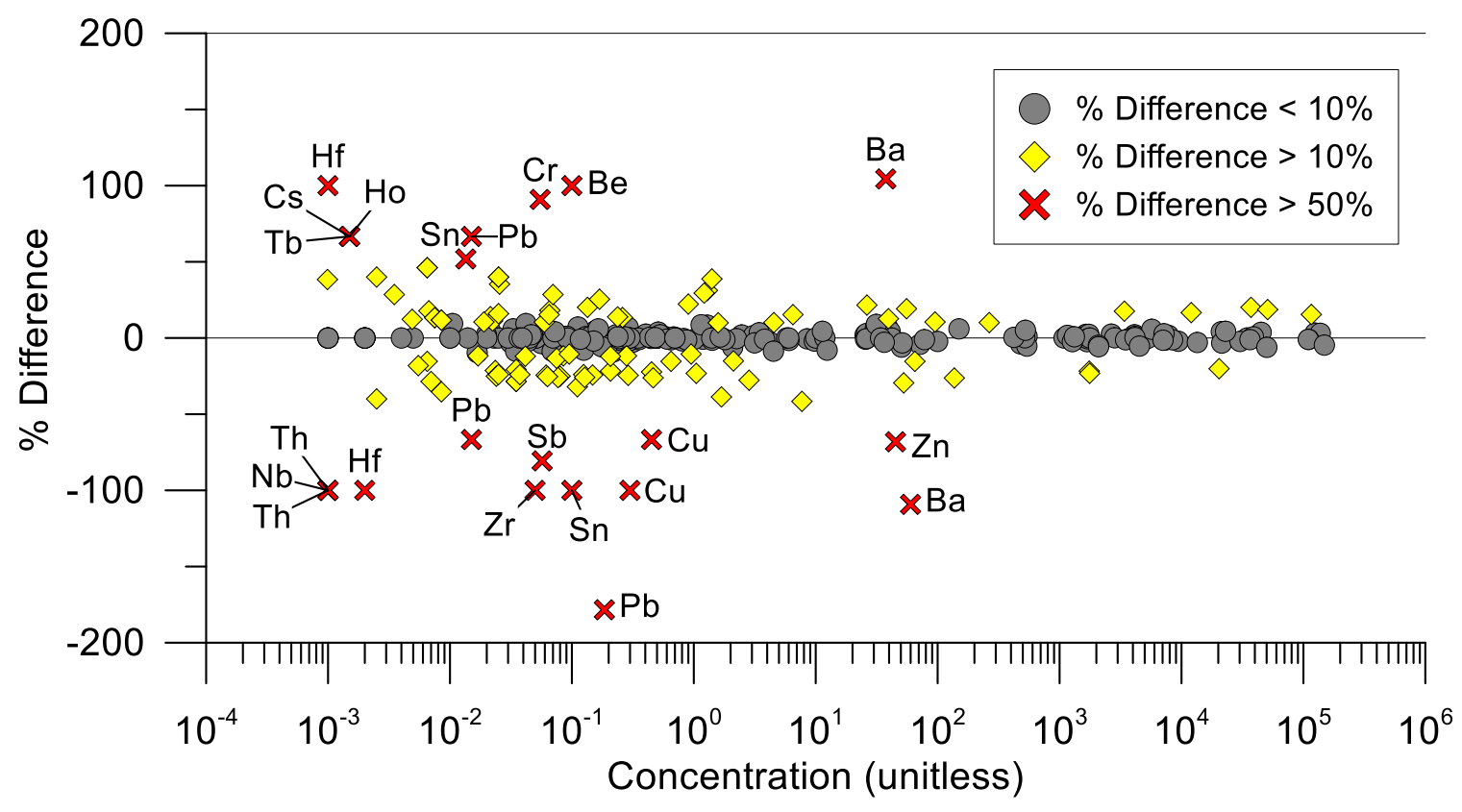

Figure 47: Percent difference results for duplicate sample pairs. 
Appendix E: Blank Sample Results 
Table E-1: Maximum Detected Concentrations in Blank Samples

\begin{tabular}{|c|c|c|c|c|c|c|c|c|c|c|c|c|}
\hline Blank Samples $(n=4)$ & $\begin{array}{r}\mathrm{Cl} \\
\mathrm{mg} / \mathrm{L}\end{array}$ & $\begin{array}{r}\mathrm{SO}_{4} \\
\mathrm{mg} / \mathrm{L}\end{array}$ & $\begin{array}{r}\mathrm{Na} \\
\mathrm{ug} / \mathrm{L}\end{array}$ & $\begin{array}{r}\mathrm{Mg} \\
\mathrm{ug} / \mathrm{L}\end{array}$ & $\begin{array}{r}\mathrm{K} \\
\mathrm{ug} / \mathrm{L}\end{array}$ & $\begin{array}{r}\mathrm{Mn} \\
\mathrm{ug} / \mathrm{L}\end{array}$ & $\begin{array}{r}\mathrm{Zn} \\
\mathrm{ug} / \mathrm{L}\end{array}$ & $\begin{array}{r}\mathrm{Sr} \\
\mathrm{ug} / \mathrm{L}\end{array}$ & $\begin{array}{r}\mathrm{Sb} \\
\mathrm{ug} / \mathrm{L}\end{array}$ & $\begin{array}{r}\mathrm{Cs} \\
\mathrm{ug} / \mathrm{L}\end{array}$ & $\begin{array}{r}\mathrm{Ba} \\
\mathrm{ug} / \mathrm{L}\end{array}$ & $\begin{array}{r}\mathrm{Ce} \\
\mathrm{ug} / \mathrm{L}\end{array}$ \\
\hline MDL & 0.12 & 0.099 & 5 & 2 & 30 & 0.1 & 0.5 & 0.04 & 0.01 & 0.001 & 0.1 & 0.001 \\
\hline Maximum Detected Concentration & 0.752 & 2.197 & 206 & 10 & 70 & 0.2 & 4 & 0.24 & 0.08 & 0.002 & 2.3 & 0.001 \\
\hline
\end{tabular}


Table E-2: All Results for Blank Samples

\begin{tabular}{|l|c|r|r|r|r|r|r|r|r|r|r|r|r|r|r|r|r|r|r|}
\hline Tracking ID & Date & $\begin{array}{r}\mathbf{C l} \\
\mathbf{m g} / \mathbf{L}\end{array}$ & $\begin{array}{r}\mathbf{S O} \\
\mathbf{m g} / \mathbf{L}\end{array}$ & $\begin{array}{r}\mathbf{N a} \\
\mathbf{u g} / \mathbf{L}\end{array}$ & $\begin{array}{r}\mathbf{L i} \\
\mathbf{u g} / \mathbf{L}\end{array}$ & $\begin{array}{r}\mathbf{B e} \\
\mathbf{u g} / \mathbf{L}\end{array}$ & $\begin{array}{r}\mathbf{M g} \\
\mathbf{u g} / \mathbf{L}\end{array}$ & $\begin{array}{r}\mathbf{A l} \\
\mathbf{u g} / \mathbf{L}\end{array}$ & $\begin{array}{r}\mathbf{S i} \\
\mathbf{u g} / \mathbf{L}\end{array}$ & $\begin{array}{r}\mathbf{K} \\
\mathbf{u g} / \mathbf{L}\end{array}$ & $\begin{array}{r}\mathbf{C a} \\
\mathbf{u g} / \mathbf{L}\end{array}$ & $\begin{array}{r}\mathbf{S c} \\
\mathbf{u g} / \mathbf{L}\end{array}$ \\
\hline MDL & $\mathbf{m m} / \mathbf{d d} / \mathbf{y y y y}$ & 0.12 & 0.099 & 5 & 1 & 0.1 & 2 & 2 & 200 & 30 & 700 & 1 \\
\hline WVU-b19-1102 & $11 / 2 / 2019$ & 0.752 & $<\mathrm{MDL}$ & 76 & $<\mathrm{MDL}$ & $<\mathrm{MDL}$ & 5 & $<\mathrm{MDL}$ & $<\mathrm{MDL}$ & $<\mathrm{MDL}$ & $<\mathrm{MDL}$ & $<\mathrm{MDL}$ \\
\hline WVU-b19-1203 & $12 / 3 / 2019$ & $<\mathrm{MDL}$ & 2.197 & 183 & $<\mathrm{MDL}$ & $<\mathrm{MDL}$ & 10 & $<\mathrm{MDL}$ & $<\mathrm{MDL}$ & 70 & $<\mathrm{MDL}$ & $<\mathrm{MDL}$ \\
\hline WVU-b20-0102 & $1 / 2 / 2020$ & $<\mathrm{MDL}$ & $<\mathrm{MDL}$ & 206 & $<\mathrm{MDL}$ & $<\mathrm{MDL}$ & 3 & $<\mathrm{MDL}$ & $<\mathrm{MDL}$ & $<\mathrm{MDL}$ & $<\mathrm{MDL}$ & $<\mathrm{MDL}$ \\
\hline WVU-b20-0216 & $2 / 16 / 2020$ & $<\mathrm{MDL}$ & $<\mathrm{MDL}$ & 98 & $<\mathrm{MDL}$ & $<\mathrm{MDL}$ & 5 & $<\mathrm{MDL}$ & $<\mathrm{MDL}$ & $<\mathrm{MDL}$ & $<\mathrm{MDL}$ & $<\mathrm{MDL}$ \\
\hline
\end{tabular}


Table E-2: All Results for Blank Samples

\begin{tabular}{|c|c|c|c|c|c|c|c|c|c|c|c|c|c|}
\hline ing ID & $\begin{array}{r}\mathrm{Ti} \\
\mathrm{ug} / \mathrm{L}\end{array}$ & $\begin{array}{r}V \\
u g / L\end{array}$ & $\begin{array}{r}\mathrm{Cr} \\
\mathrm{ug} / \mathrm{L} \\
\end{array}$ & $\begin{array}{c}\mathrm{Mn} \\
\mathrm{ug} / \mathrm{L}\end{array}$ & $\begin{array}{r}\mathrm{Fe} \\
\mathrm{ug} / \mathrm{L}\end{array}$ & $\begin{array}{r}\mathrm{Co} \\
\mathrm{ug} / \mathrm{L}\end{array}$ & $\begin{array}{r}\mathrm{Ni} \\
\mathrm{ug} / \mathrm{L}\end{array}$ & $\begin{array}{r}\mathrm{Cu} \\
\mathrm{ug} / \mathrm{L}\end{array}$ & $\begin{array}{r}\mathrm{Zn} \\
\mathrm{ug} / \mathrm{L}\end{array}$ & $\begin{array}{r}\mathbf{G a} \\
\mathrm{ug} / \mathrm{L}\end{array}$ & $\begin{array}{r}\mathrm{Ge} \\
\mathrm{ug} / \mathrm{L}\end{array}$ & $\begin{array}{r}\mathrm{As} \\
\mathrm{ug} / \mathrm{L}\end{array}$ & $\begin{array}{r}\mathrm{Se} \\
\mathrm{ug} / \mathrm{L} \\
\end{array}$ \\
\hline MDL & 0.1 & 0.1 & 0.05 & 0.1 & 10 & 0.005 & 0.3 & 0.2 & 0.5 & 0.01 & 0.01 & 0.03 & 0.2 \\
\hline WVU-b19-1102 & $<\mathrm{MDL}$ & $<\mathrm{MDL}$ & $<\mathrm{MDL}$ & 0.2 & $<\mathrm{MDL}$ & $<\mathrm{MDL}$ & $<\mathrm{MDL}$ & $<\mathrm{MDL}$ & $<\mathrm{MDL}$ & $<\mathrm{MDL}$ & $<\mathrm{MDL}$ & $<\mathrm{MDL}$ & $<\mathrm{MDL}$ \\
\hline WVU-b20-0102 & $<\mathrm{MDL}$ & $<\mathrm{MDL}$ & $<\mathrm{MDL}$ & 0.1 & $<\mathrm{MDL}$ & $<\mathrm{MDL}$ & $<\mathrm{MDL}$ & $<\mathrm{MDL}$ & 0.8 & $<\mathrm{MDL}$ & $<\mathrm{MDL}$ & $<\mathrm{MDL}$ & $<\mathrm{MDL}$ \\
\hline WVU-b20-0216 & $<\mathrm{MDL}$ & $<\mathrm{MDL}$ & $<\mathrm{MDL}$ & $<\mathrm{MDL}$ & $<\mathrm{MDL}$ & $<\mathrm{MDL}$ & $<\mathrm{MDL}$ & $<\mathrm{MDL}$ & 2.1 & $<\mathrm{MDL}$ & $<\mathrm{MDL}$ & $<\mathrm{MDL}$ & $<\mathrm{MDL}$ \\
\hline
\end{tabular}


Table E-2: All Results for Blank Samples

\begin{tabular}{|l|r|r|r|r|r|r|r|r|r|r|r|r|r|}
\hline Tracking ID & $\begin{array}{r}\mathbf{R b} \\
\mathbf{u g} / \mathrm{L}\end{array}$ & $\begin{array}{r}\mathbf{S r} \\
\mathbf{u g} / \mathrm{L}\end{array}$ & $\begin{array}{r}\mathbf{Y} \\
\mathbf{u g} / \mathrm{L}\end{array}$ & $\begin{array}{r}\mathbf{Z r} \\
\mathbf{u g} / \mathrm{L}\end{array}$ & $\begin{array}{r}\mathbf{N b} \\
\mathbf{u g} / \mathrm{L}\end{array}$ & $\begin{array}{r}\mathbf{M o} \\
\mathbf{u g} / \mathbf{L}\end{array}$ & $\begin{array}{r}\mathbf{A g} \\
\mathbf{u g} / \mathrm{L}\end{array}$ & $\begin{array}{r}\mathbf{C d} \\
\mathbf{u g} / \mathbf{L}\end{array}$ & $\begin{array}{r}\mathbf{I n} \\
\mathbf{u g} / \mathbf{L}\end{array}$ & $\begin{array}{r}\mathbf{S n} \\
\mathbf{u g} / \mathbf{L}\end{array}$ & $\begin{array}{r}\mathbf{S b} \\
\mathbf{u g} / \mathbf{L}\end{array}$ & $\begin{array}{r}\mathbf{T e} \\
\mathbf{u g} / \mathbf{L}\end{array}$ & $\begin{array}{r}\mathbf{C s} \\
\mathbf{u g} / \mathbf{L}\end{array}$ \\
\hline MDL & 0.005 & 0.04 & 0.003 & 0.01 & 0.005 & 0.1 & 0.2 & 0.01 & 0.001 & 0.1 & 0.01 & 0.1 & 0.001 \\
\hline WVU-b19-1102 & $<\mathrm{MDL}$ & 0.17 & $<\mathrm{MDL}$ & $<\mathrm{MDL}$ & $<\mathrm{MDL}$ & $<\mathrm{MDL}$ & $<\mathrm{MDL}$ & $<\mathrm{MDL}$ & $<\mathrm{MDL}$ & $<\mathrm{MDL}$ & 0.08 & $<\mathrm{MDL}$ & 0.002 \\
\hline WVU-b19-1203 & $<\mathrm{MDL}$ & 0.24 & $<\mathrm{MDL}$ & $<\mathrm{MDL}$ & $<\mathrm{MDL}$ & $<\mathrm{MDL}$ & $<\mathrm{MDL}$ & $<\mathrm{MDL}$ & $<\mathrm{MDL}$ & $<\mathrm{MDL}$ & 0.07 & $<\mathrm{MDL}$ & $<\mathrm{MDL}$ \\
\hline WVU-b20-0102 & $<\mathrm{MDL}$ & 0.08 & $<\mathrm{MDL}$ & $<\mathrm{MDL}$ & $<\mathrm{MDL}$ & $<\mathrm{MDL}$ & $<\mathrm{MDL}$ & $<\mathrm{MDL}$ & $<\mathrm{MDL}$ & $<\mathrm{MDL}$ & 0.08 & $<\mathrm{MDL}$ & $<\mathrm{MDL}$ \\
\hline WVU-b20-0216 & $<\mathrm{MDL}$ & 0.16 & $<\mathrm{MDL}$ & $<\mathrm{MDL}$ & $<\mathrm{MDL}$ & $<\mathrm{MDL}$ & $<\mathrm{MDL}$ & $<\mathrm{MDL}$ & $<\mathrm{MDL}$ & $<\mathrm{MDL}$ & 0.08 & $<\mathrm{MDL}$ & $<\mathrm{MDL}$ \\
\hline
\end{tabular}


Table E-2: All Results for Blank Samples

\begin{tabular}{|l|r|r|r|r|r|r|r|r|r|r|r|r|r|}
\hline Tracking ID & $\begin{array}{r}\mathbf{B a} \\
\mathbf{u g} / \mathrm{L}\end{array}$ & $\begin{array}{r}\mathbf{L a} \\
\mathbf{u g} / \mathrm{L}\end{array}$ & $\begin{array}{r}\mathbf{C e} \\
\mathbf{u g} / \mathrm{L}\end{array}$ & $\begin{array}{r}\mathbf{P r} \\
\mathbf{u g} / \mathrm{L}\end{array}$ & $\begin{array}{r}\mathbf{N d} \\
\mathbf{u g} / \mathrm{L}\end{array}$ & $\begin{array}{r}\mathbf{S m} \\
\mathbf{u g} / \mathbf{L}\end{array}$ & $\begin{array}{r}\mathbf{E u} \\
\mathbf{u g} / \mathrm{L}\end{array}$ & $\begin{array}{r}\mathbf{G d} \\
\mathbf{u g} / \mathbf{L}\end{array}$ & $\begin{array}{r}\mathbf{T b} \\
\mathbf{u g} / \mathbf{L}\end{array}$ & $\begin{array}{r}\mathbf{D y} \\
\mathbf{u g} / \mathbf{L}\end{array}$ & $\begin{array}{r}\mathbf{H o} \\
\mathbf{u g} / \mathbf{L}\end{array}$ & $\begin{array}{r}\mathbf{E r} \\
\mathbf{u g} / \mathbf{L}\end{array}$ & $\begin{array}{r}\mathbf{T m} \\
\mathbf{u g} / \mathbf{L}\end{array}$ \\
\hline MDL & 0.1 & 0.001 & 0.001 & 0.001 & 0.001 & 0.001 & 0.001 & 0.001 & 0.001 & 0.001 & 0.001 & 0.001 & 0.001 \\
\hline WVU-b19-1102 & 2.3 & $<\mathrm{MDL}$ & $<\mathrm{MDL}$ & $<\mathrm{MDL}$ & $<\mathrm{MDL}$ & $<\mathrm{MDL}$ & $<\mathrm{MDL}$ & $<\mathrm{MDL}$ & $<\mathrm{MDL}$ & $<\mathrm{MDL}$ & $<\mathrm{MDL}$ & $<\mathrm{MDL}$ & $<\mathrm{MDL}$ \\
\hline WVU-b19-1203 & 0.9 & $<\mathrm{MDL}$ & 0.001 & $<\mathrm{MDL}$ & $<\mathrm{MDL}$ & $<\mathrm{MDL}$ & $<\mathrm{MDL}$ & $<\mathrm{MDL}$ & $<\mathrm{MDL}$ & $<\mathrm{MDL}$ & $<\mathrm{MDL}$ & $<\mathrm{MDL}$ & $<\mathrm{MDL}$ \\
\hline WVU-b20-0102 & 0.8 & $<\mathrm{MDL}$ & $<\mathrm{MDL}$ & $<\mathrm{MDL}$ & $<\mathrm{MDL}$ & $<\mathrm{MDL}$ & $<\mathrm{MDL}$ & $<\mathrm{MDL}$ & $<\mathrm{MDL}$ & $<\mathrm{MDL}$ & $<\mathrm{MDL}$ & $<\mathrm{MDL}$ & $<\mathrm{MDL}$ \\
\hline WVU-b20-0216 & 1.1 & $<\mathrm{MDL}$ & $<\mathrm{MDL}$ & $<\mathrm{MDL}$ & $<\mathrm{MDL}$ & $<\mathrm{MDL}$ & $<\mathrm{MDL}$ & $<\mathrm{MDL}$ & $<\mathrm{MDL}$ & $<\mathrm{MDL}$ & $<\mathrm{MDL}$ & $<\mathrm{MDL}$ & $<\mathrm{MDL}$ \\
\hline
\end{tabular}


Table E-2: All Results for Blank Samples

\begin{tabular}{|l|r|r|r|r|r|r|r|r|r|r|r|}
\hline Tracking ID & $\begin{array}{r}\mathbf{Y b} \\
\mathbf{u g} / \mathrm{L}\end{array}$ & $\begin{array}{r}\mathbf{L u} \\
\mathbf{u g} / \mathrm{L}\end{array}$ & $\begin{array}{r}\mathbf{H f} \\
\mathbf{u g} / \mathbf{L}\end{array}$ & $\begin{array}{r}\mathbf{T a} \\
\mathbf{u g} / \mathbf{L}\end{array}$ & $\begin{array}{r}\mathbf{W} \\
\mathbf{u g} / \mathbf{L}\end{array}$ & $\begin{array}{r}\mathbf{H g} \\
\mathbf{u g} / \mathbf{L}\end{array}$ & $\begin{array}{r}\mathbf{T l} \\
\mathbf{u g} / \mathbf{L}\end{array}$ & $\begin{array}{r}\mathbf{P b} \\
\mathbf{u g} / \mathbf{L}\end{array}$ & $\begin{array}{r}\mathbf{B i} \\
\mathbf{u g} / \mathbf{L}\end{array}$ & $\begin{array}{r}\mathbf{T h} \\
\mathbf{u g} / \mathbf{L}\end{array}$ & $\begin{array}{r}\mathbf{U} \\
\mathbf{u g} / \mathbf{L}\end{array}$ \\
\hline MDL & 0.001 & 0.001 & 0.001 & 0.001 & 0.02 & 0.2 & 0.001 & 0.01 & 0.3 & 0.001 & 0.001 \\
\hline WVU-b19-1102 & $<\mathrm{MDL}$ & $<\mathrm{MDL}$ & $<\mathrm{MDL}$ & $<\mathrm{MDL}$ & $<\mathrm{MDL}$ & $<\mathrm{MDL}$ & $<\mathrm{MDL}$ & $<\mathrm{MDL}$ & $<\mathrm{MDL}$ & $<\mathrm{MDL}$ & $<\mathrm{MDL}$ \\
\hline WVU-b19-1203 & $<\mathrm{MDL}$ & $<\mathrm{MDL}$ & $<\mathrm{MDL}$ & $<\mathrm{MDL}$ & $<\mathrm{MDL}$ & $<\mathrm{MDL}$ & $<\mathrm{MDL}$ & $<\mathrm{MDL}$ & $<\mathrm{MDL}$ & $<\mathrm{MDL}$ & $<\mathrm{MDL}$ \\
\hline WVU-b20-0102 & $<\mathrm{MDL}$ & $<\mathrm{MDL}$ & $<\mathrm{MDL}$ & $<\mathrm{MDL}$ & $<\mathrm{MDL}$ & $<\mathrm{MDL}$ & $<\mathrm{MDL}$ & $<\mathrm{MDL}$ & $<\mathrm{MDL}$ & $<\mathrm{MDL}$ & $<\mathrm{MDL}$ \\
\hline WVU-b20-0216 & $<\mathrm{MDL}$ & $<\mathrm{MDL}$ & $<\mathrm{MDL}$ & $<\mathrm{MDL}$ & $<\mathrm{MDL}$ & $<\mathrm{MDL}$ & $<\mathrm{MDL}$ & $<\mathrm{MDL}$ & $<\mathrm{MDL}$ & $<\mathrm{MDL}$ & $<\mathrm{MDL}$ \\
\hline
\end{tabular}

